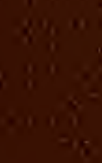

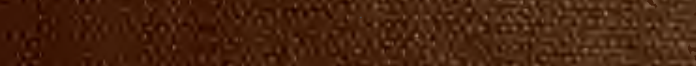

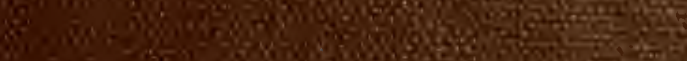

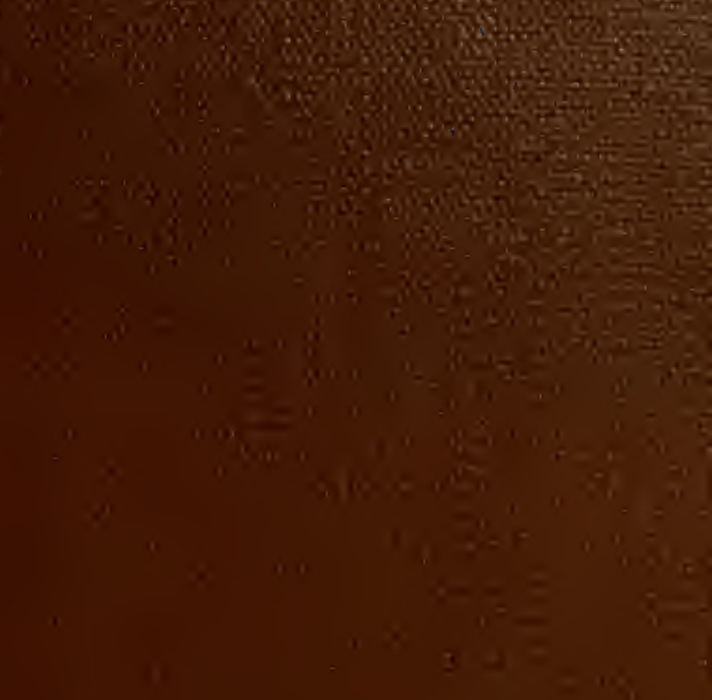




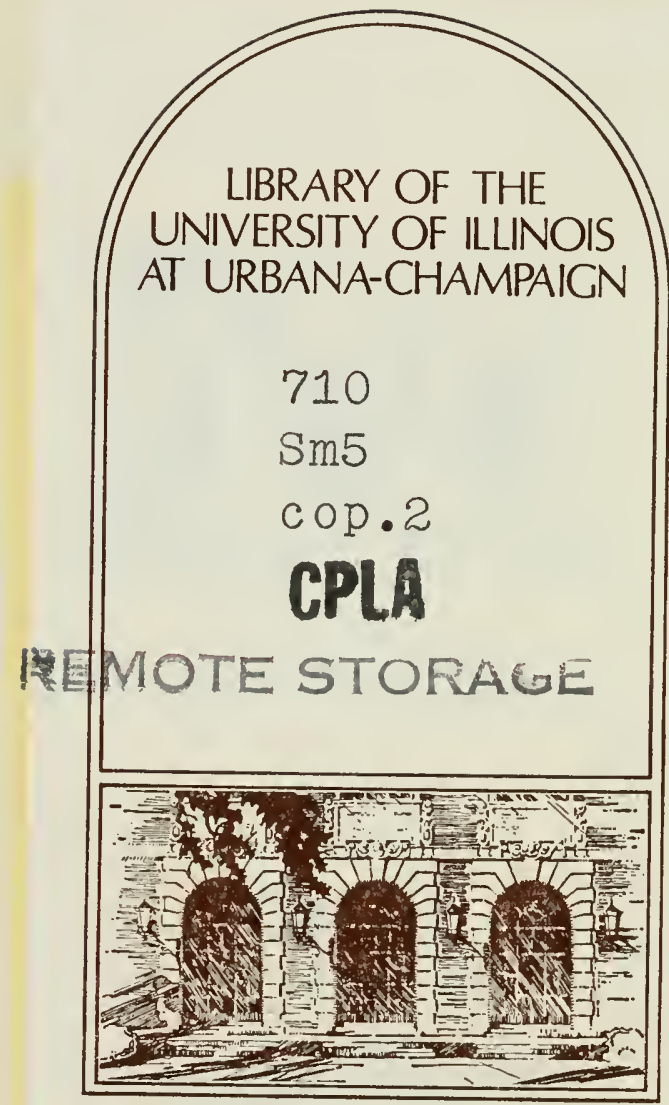


The person charging this material is responsible for 1 ts return on or before the Latest Date stamped below.

Theft, mutilation, and underlining of books are reasons for disciplinary action and may result in dismissal from the University.

UNIVERSITY OF ILLINOIS LIBRARY AT URBANA-CHAMPAIGN

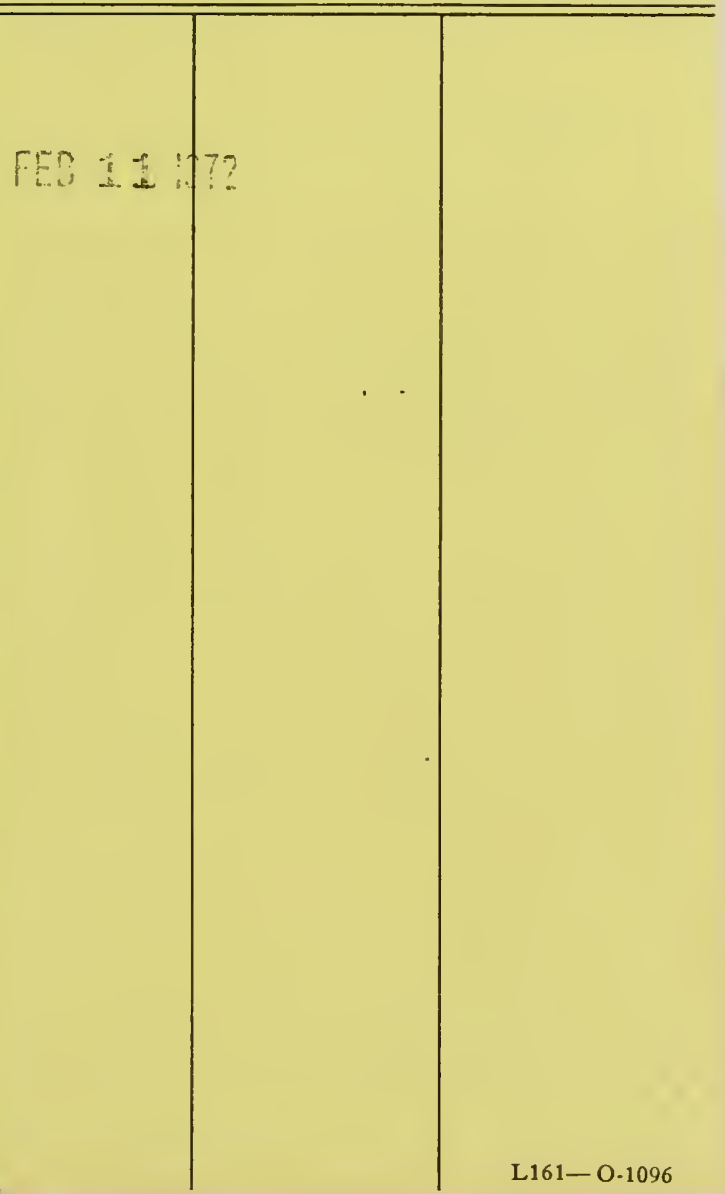





\title{
LANDSCAPE GARDENING:
}

ora

\section{PARKS AND PLEASURE GROUNDS.}

\author{
'wITH \\ PRACTICAL NOTES \\ ON
}

\section{COUNTRY RESIDENCES, VILLAS,}

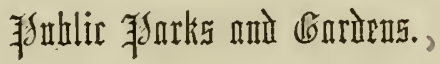

BY

CHARLES H. J. S M I TH,

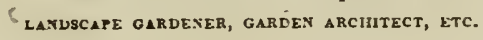

WITH

\section{NOTES AND ADDITIONS.}

B Y LEW IS F. A L L E ,

Author of "Rural Architecture," \&c. ,

\author{
NET YORK: \\ 'C. M. SAXTON \& COMPANY, \\ agricclteral Book Prbliehrers, 140 ficlton Sr. \\ 1856.
}


Entered according to act of Congress, in the year 1853 , by

C. M. SAXTON,

in the Clerk's Office of the District Court of the United States, for the Southern District of New York. 

and his retainers. His noblemen followed the royal example, and a great part of England was parceled out into wide domains - the spoils of the conquered Saxons - and appropriated to themselres, in ranges of park and cultivated lands. Hunting was their pastime - war, agriculture and legislation their employment. Through succeeding centuries, becoming more refined and domestic in their pursuits, they studied the improvement and cultivation of their estates; and, retaining their attachment to the soil, which they held by liereditary title, the planting and preserration of their trees, and the decoration of their gardens, became with them a passion, as well as a duty. It is so with their descendants in the present day. It has become a national taste in England, and has spread into Scotland and Ireland, until no country in the world can equal Great Britain in the luxuriance and beautythe costliness and splendor - the extent and the wealth of her Parks and Pleasure-grounds. Few, indeed, can indulge in such extent of luxury as the parks of the aristocracy display; yet the taste for rural embellishment extends among all classes of the people, from the royal mistress of Windsor, Osborne, and Balmoral, to the humble cottager upon his meager allotment by the hedge-row.

It is not so in America. We have broad lands, and a passion for lands; but not a passion to improve and embellish them for domestic occupation, as they hare in England. Yet we are learning this, and we wish to learn more. Our taste. 
is improving. We are encouraging skillful and ingenious men, who are aiding us in forming our tastes, by their writings and their labors. We require practical treatises, adapted to our own country. Foreign books are not sufficient for us. Good, many of them are: suggestive in many things, and instructive in others. The work here presented has appeared to the undersigned better suited to the American inquirer than any other which has issued from a foreign press. It is plainly, unambitiously, sensibly written, and by a thoroughly practical man. It will do much to instruct us in the subjects on which it discourses, and with suitable notes appended, may, perhaps, be more useful to the American reader than without them Such notes have been attempted by the undersigned-whether acceptably, or not, is submitted to the reader.

Bufralo, August, 1853. 


\section{AUTHOR'S PREFACE.}

THE design of the following work is altogether a practical one. While engaged in his profession, during the last eighteen years, the author has often been requested to recommend a book, which might enable persons consulting him to acquire some general knowledge of the principles of Landscape-gardening, and which might aid them in carrying his suggestions into effect. He has been in the habit of naming certain well-known works, such as Price "On the Picturesque," and Gilpin "On Landscape-gardening." He has often felt, however, that such advice was, in great measure, illusory; and that if implicitly followed, it would tend rather to puzzle than to enlighten or direct those who might adopt it. He himself had experienced the difficulty of making practical application of the general reasonings, and of the diffuse, and, at times, irrelevant discussions to be found in some of these authors; and it was only by means of light derived from his own practice that he was able to put them to profit. In the work of Price, for example, the leading precepts substantially 
are: Study pictures - familiarize your taste with scenes which painters would delight to copy - become acquainted with the elements of the picturesque, and seek to realize the resulting.ideas in and about your residence. Most gentlemen of liberal education know something of pictures; but there are few who would not disclaim such a special culture in the fine arts, as would fit them to apply the principles of painting to the improvement of their grounds. To prescribe such a course is virtually to require a professional education, or to impose the amateur labor of half a lifetime. The object of the present work is to preserve a plain and direct method of statement, to be intelligible to all who have had an ordinary education, and to give directions which, it is hoped, will be found to be practical by those who have an adequate knowledge of country affairs.

The author earnestly disclains all intention of detracting from the acknowledged merit of his illustrious predecessors. He has been willing to sit at the fect of Wheatley, Price and Gilpin. He has learned much from their writings. His aim, in this volume, has been to popularize their principles, and to simplify and extend their processes in practice. He has, however, sedulously aroided those redundant and often merely controversial discussions by which some of their literary works are encumbered. At the same time he is convinced that Landscape-gardening, like the other fine arts, is of a progressive nature; and that its ascertained principles compose a fabric 
to which successive writers have added, or have yet * \& 1 , each his stick and his stone. He has endeavored to do his part. While, however, he has not been inattentive to the literature of his profession, he has looked even more intently at nature; he has sought to draw directly from her inexhaustible stores; and in offering to the public the results of his observations, he humbly trusts that he has contributed to the progress of the art.

In adding to his original plan two chapters on the Arboretum and the Pinetum, the author has sought to supply a want in regard to ornamental collections of trees, which is becoming daily more apparent. So far as his limited space has allowed, he has endearored to treat these subjects on the principles both of science and taste; and he hopes that the botanical information, which he has drawn from the best sources, though it may be uninteresting to the general reader, will not be unacceptable to the lovers of these pleasing de. partments of Arboriculture.

Edinburgh, August, 1852. 


\section{CONTENTS.}

\section{CHAPTER I.}

THE HOUSE AND OFFICES.

Introduction-Climate of the site-Soil and Subsoil-DrainageSupply of Water-Shelter-Position of the House in the ParkElevation of the Site-Extent of the Site-Style of the HouseArrangement of the Interior of the House-Conservatory-Stablecourt and Offices, . $\quad . \quad$. . . .

\section{CHAPTER II.}

\section{THE APPROACH.}

Definition-Direction of the Approach-Site of the Entrance-gateStyle of the Gate and Lodge-Line of Approach through the Park-Gates on the Line of Approach-Termination of the Approach-Roadway of Approach-Decoration of ApproaehThe Arenue-The Fine Approach, . . . . 52

\section{CHAPTER III.}

\section{PLEASURE-GROUNDS AND FLOWER-GARDENS.}

Position of the Pleasure-grounds-Composition of the LandscapeTerraces-Walls-Grass Slopes-Shrubs on T'errace-banksStairs on Terraces-the Upper Surface of Terraces-The Flowergarden-Site of the Flower-garden-Ground Color-The Parterre-The Rosary-The American Garden-The Mixed Flowergarden-Artistical Decorations-Rockworks-Shelter of the Flower-garden-Planting in the Pleasure-grounds-Walks $i, x$ the Pleasure-grounds-Formation of Lawns, . . . . . is 


\section{CHAPTER IV.}

THE PARIK.

Definition-The Unity of the Park-Natural Character of the Ground-Acquired Character of the Ground-Planting in the Park-Surfaces to be Planted-Arrangement of Woods in the Park-a Group-a Clump-a Mass-Carrying out the Arrangement of Woods-Grouping of Plantations in the Park-Outlines of Plantations-Belts and Circles-Artificial Style-Arenues, . 105

\section{CHAPTER V.}

ORNAMENTAL CHARACTFRS OF TREES, DETACHED AND IN COMBINATION.

Introductory Remarks.

Sect. I. The forms of Single Trees-Broad Round-headed Trees-

The Spiry, Conical, or Pyramidal Configuration-The Upriglit or Oblongated-The Weeping or Pendulous.

SECT. II. The Color of Trees-Table of the Colors of Foliage of Trees-General Remarks.

Sect. III. The Ornamental Character of Trees in CombinationConical or Pyramidal Trees-Round-headed Trees-Intermingling of the different Forms and Colors-Concluding Remarks, . 135

\section{CHAPTER VI.}

\section{PLANTING.}

Preparation of the Ground-Trenching-Draining-Roads through Plantations-Planting of Forest Trees-Pitting-Pruning-Thinning-Transplanting Forest Trees-Planting and Transplanting of Evergreens,

\section{CHAPTER VII.}

FENCES OF THE PARK AND PLEASURE-GROUNDS. Creneral Remarks-Boundary Fence-Internal Fences-Fence of the Deer Park-Pleasure-ground Fences-Malleable-iron FencesSunk Fences-Stone Walls-Hedges, . . . . 184 


\section{CHAP'TER VIII.}

IVATER。

Artificial Lakes-Islands-the Head or Artificial EmbankmentDecorative Accompaniment-Artificial Rivers-Jet FountainsJets d'Eau-Propriety of Introducing Water,

\section{- CHAPTER IX.}

THE KITCHEN, FRUIT, AND IORCING GARDENS.

Introduction-The Site-Drainage-Soil-The Form-The Walls-

The Fruit Garden-The Forcing Garden, . . . . . 203

\section{CHAPTER X. \\ PUBLIC PARKS AND GARDENS.}

Secr. I. The Public Park-Site of the Public Park-Laying-out of Public Parks-Educational Institutions.

SEcT. II. Street Gardens.

Sect. III. Botanic Gardens-Special Purposes of Botanical Gal dens-Botanical Muscums-Laying-out of the Botanic Gardens.

Szcr. IV. Gardens belonging to Horticultural and Zoological Societies-Gardens of Horticultural Societies-Laying-out of Horticultural Gardens-Horticultural Museunı-Zoological Gardens, . 215

\section{CHAPTER XI.}

THE VILLA.

Introductory Remarks.

Sect. I. General Properties of the Villa-The Locality-The SiteRoads-Position of the House-Style and Arrangement of the House.

SEOT. II. Laying-out of the Grounds of a Villa-Seclusion-The Approach-Kitchen-garden-Trees and Shrubs-Water-Leading Varieties of Villa Scenery-The Pleasure-ground Villa-The Park Villa, . . . . . . 


\section{CHAPTER XII.}

GENERAL OBSERVATIONS ON THE LAYING-OUT AND IMPROVEMENT OF GROUNDS.

Landscape-gardening-Analogies to Landscape-painting-Consparative Power orcr Materials-Simpiicity and Multiplicity of Points of View-Processes wholly and partly Tentative-Propriety of Rerision-Utility of Plans-Hazard of Preparatory Operations,

\section{CHAPTER XIII.}

THE ARBORETUM.

Definition-Recent Introduction-General Idea of ArrangementSxcr. I. Scientific Treatment of the Arboretum-Introductory Remarks-D1. Lindley's Classification of the Natural OrdersExplanations-Synopsis of Orders and Genera-Application of Principles-Transference of the System to the Ground.

Sicr. II. Decoratire Treatment of the Arboretum-Object in ViewEmployment of Larger Trees-Lawns-Surfaces planted-Evergreens-A.rboretums attached to Prirate Residences-Sites in illeasure-grounds.

\section{CHAPTER XIV.}

THE PINETUM.

Remarks on Special Collections of Trees-The Pinetum-Materials and Arrangement-Enumeration of Species, with Observations on the Groups-Effects of Climate-Soil-Early Cultiration of the Plants-Planting of the Piuetum-Pruning of the Trees-Decorative Treatment of the Pinetum, 


\section{PARKS AND PLEASURE-GROUNDS}

TITA

\section{AMERICAN NOTES.}

\section{CHAPTER I. \\ THE HOUSE AND OFFICES.}

Introduction-Climate of the Site-Soil and Subsoil-Drainage-Supply of Water-Shelter-Position of the House in the Park-Eleration of the Site-Extent of the Site-Style of the House-Arrangement of the Interior of the House-Conservatory-Stable Court and Offices.

TuE house, being the head-quarters of the familythe capital, as it were, of the park or demesne-is by far the most important object within the grounds, and, as such, the selection of the site must take precedence of all other matters, whether it be a castle or a cottage, and whaterer be its form and construction. While this ought to be the dominant principle in the formation of a country residence, and while the louse should be made the central point, to which all operations connected with the laying out of the park and pleasuregrounds slould be referred; there are certain requirements belonging to a mansion-house, as a comfortable dwelling, which must be allowed to modify the final clioice of site as the best upon the whole world. 
Climate of the Site.-The general temperature and dryness of the air lave a material influence on the health and comfort of a family, and, therefore, must reeeive due consideration. These qualities resolve themselves very much into those of the park, and of the district. in which it is situated. Along the eastern shores of the United Kingdom, and in the eountry adjacent to these, in some plaees to a eonsiderable distance inland, the elimate is comparatively dry and good; but in spring and in the beginning of summer, when cold withering winds from the sea are prevalent, the east eoast is found to be very trying to the eonstitutions of some individuals. On the west coast, and in the districts bordering on it, there is a much greater degree of humidity, which, though in itself disagreeable, is accompanied with a softness and mildness that at eertain seasons make the climate pleasant and beneficial to those whose health is affected by the rude severities of the center and the east. The interior hilly or mountainous regions of our island have a climate peculiar to themselves; yet, with a rarying amount of moisture and dryness, and of cloudy or elear atmosphere, they are generally healthy and braeing, and partake of the eharacters of the east and west, aecording as they approach to either eoast. Some of the inland and slightly hilly districts toward the east have muchl of its dryness without its peculiar severity in spring, and may, therefore, be accounted the best. The general elimate of the park, then, may be said to be the ruling one for the mansion-house; but in large, and even in what may be eonsidered small parks, there are often loealities which have modifieations peculiar to themselves. These variations, thongh inconsiderable 
on flat surfaces, are sufficiently marked on undulating and billy ones. Southern exposures are decidedly superior, in point of warmth, to northern slopes, or places lying toward the east or west. Good sites are found in the latter direction, but they are occasionally inclement; when such positions are sclected, they should accupy, if possible, a western declivity on the east, and an eastern declivity on the west side of the cunntry. High and exposed situations are cold, but have a clear and bracing atmosphere. Windy positions are to be avoided; as also those which are exposed to draughts of cold air, a peculiarity less apparent to slight inspection than the other, but not less disagreeable and injurious in its effects. Aware of this, the inhabitants of hilly countries generally place the ends of their houses toward the length of the valleys, as the winds, for the most part, sweep up and down them, in whatever direction they run; and by this arrangement the houses are assailed by fewer cross-draughts than when they are set down across the valley. In dry; well-sheltered localities, near the sea-coast, these peculiarities of climate are less frequently experienced than in more inland regions.

Note-Although written for the humid climate of the British Isles, these remarks are worthy of consider. ation in the dryer atmosphere of America. In many localities of our new states, owing to canses of disease, which a more extensive improrement and clearing up of the country will avate, the best sites for dwellings can not with safety be occupied. In the older states there are districts still subject to autumnal fevers, chills and agues, chiefly in the vicinity of sluggish water-courses, or undrained swamps, or marshes. It 
such, the best positions for a dwelling cannot be occupied until a more rapid flow of the water be effected by clearing the streams of their obstructions, and the low grounds are drained of their standing water. In an open country, long settled, and its climate defined, every one desirous to build, will readily ascertuin the advantages or defects of the site on which he prefers to erect his dwelling. A combination of objects usnally control the selection of the site, and no rule can be laid down which will govern in all cases. To those who have a wide range of choice in this particular, and are not pressed for time, we would suggest the erection of a temporary cottage on one or more sites which please their taste, in which a family might be lodged, with a thermometer to note the ranges of heat and cold, and the currents of wind, as they affect the spot adversely, or otherwise. We have known instances where an apparently well-sheltered valley, by the poculiar conformation of the adjacent hills, was swept witl stronger and harsher winds than an exposed promontory in its immediate neighborhood. $\Lambda$ hilly or a mountainons region requires closer examination to determine accurately the degrces of temperature, and the currents of air to which they are exposed, than an open, flat country, with nothing to break off or interrupt the winds but the occasional shelter of trees. As a general rule, too much importance crnnot be given to climate in the selection of the grounds for a park, or the buildings within it. A mistake in this particular may be attended with the most calamitous results, not only affecting the amount of capital invested, but cxtending even to life itself.-ED.

Soll and Subsoll of the Site.-The nature of the 
soil and subsoil of a place have a much greater influence on its climate than at first sight might be supposed. In our risits to country residences, we have often fom remarkable differences of climate, which could be assigned to no other canse. Those on light dry soils and subsoils seemed clieerful and agreeable dnring winter, while others, in the same district, with wet soils and retentive subsoils, were damp, muddy, and uncomfortable. These differences conld not fairly be attributed to differences in artificial drainage, for they were often risible on the same estate, and perhaps in the same park, one field being moist and slabby, and another being dry and airy. A little observation only is required to note these peculiarities in the various localities. Invalids are very sensible to their influences. Those places to which slight frosts are most easily attracted will always be found, if not with wet surface soils, certainly with cold, retentive, humid subsoils. These evils are best counteracted by thorough drainage; but this remedy is not always effectual, or, to be so, would need to be extended to a considerable range of country. Where perfect drainage camnot be secured, no residence should be formed. We should even hesitate to recommend the erection of a house on a cold site, with a tilly subsoil ; for, however well drained the surface may be, the air in such situations is commonly raw and chill.

Note.-The above is sound doctrine, which cannot be too closely studied by all who build a residence in the country. We have known spots, beantiful in location, but so irreclaimably unfit for a family residence, that after all the desired improvements had been made at a great expense to fit it for occupation, it had to be 
abandoned. There are other places, apparently as forbidding when in a natural state, which are susceptible of entire anclioration by draining. These can usually be detcrmined by a geological survey of the grounds, and a thorongh examination of the kinds of tree and shrubbery which most incline to grow upon them. In all cases of doubt of the practicability of a thorongh drainage, and a consequent warnth and kindliness of the soil for the objects required, the proposed site for the residence should at once be abandoned. The selection and improrement of a position which shall prove unfit for a perfectly wholesome and satisfactory residence, will remain a source of perpetual annoyance and regret.-ED.

Draisage of the Site.-It is important that the site should at least possess that molerate elevation which will facilitate the drainage, not only of the locality which it inmediately occupies, but the whole of its environs. The lower apartments of the house slould be made completely dry, and free from the effects of surface-water wr neighboring springs. Easy and well-concealed sewerage fiom the house and offices is matter worthy of careful attention. Indeed, the thorough drainage, not merely of the honse and gromuds, but of the park, and of the whole estate commanded by the windows, should be deemed indispensable. Let the reader imagine a house set down on a bank orerhanging a fat, marshy country of many hundred acres in extent: nothing woukd be more dismal than the prospect in the first instance, and nothing might be more difficult and laborious than the subsequent efforts to improre it.

Note-Any one within the limits of the United 
States who should seriously contemplate building in the borders of an undrainable marsh, contemplating to use it for a park or pleasure-ground, would be considered a prominent candidate for a lumatic asylum. Thanks to the free range we enjoy, no such acts of folly are likely to occur. Yet the necessity of a thorough drainage to the site, and which, in many desirable localitics, is not at first apparent, is indispensable to the proper occupation of the premises. A stiff and retentive subsoil, in our dry American climate, is not objectionable to a building site, if it have sufficient descent to pass off the drains without hindrance. We should not make it an objection, if, on other accounts, the position were advantageous.-ED.

Strply of WATER.-Water, in sufficient quantity and of good quality, is another requisite which must receive due attention in determining the site of a house. Sometimes an adequate supply of this necessary of life is by no means of easy attainment. Wells, tanks, reservoirs with pipes, and hydraulic rams, have all been resorted to, according as the natural surface of the estate has allowed or compelled the employment of one or other of these. A fountain or reservoir above the level of the mansion-house certainly deserves the preference wherever it can be formed, though its original expense may be considerable. This plan affords the greatest facilities for the introduction of water into the various apartments of the house and offices, and for yielding a sufficient supply in case of fire, a matter of some importance in regard to the safety of the property. An abundant reservoir, placed as indicated above, will provide with water the fountains on the terraces, and in the flower-gardens and pleasure-grounds. In some 
grarelly subsorls, even when the surface is compara. tively dry, a considerable quantity of water may sometimes be found at no great depth, and may be obtained by means of wells and force-pumps; but the supply can hardly ever be so abundant as that yielded by the reservoir, and the labor required to raise it is very great. The hydraulic ram is a very useful instrument where only a moderate quantity of water is needed. A small stream, with a few feet of fall, will keep it in operation, and will enable it to raise the water to a tank, say on the top of the mansion-house, whence it may be distributed as required. TVe have, however, seen it used, and, independently of the price of the machine, very considerable expense incurred, where, but for inattention or ignorance in some quarter, the much more efficient system described above might have been successfully adopted, with little or no increase of cost.

Note-A windmill may oftentimes be substituted for other machinery to raise water for the supply of a liomse and grounds when a suitable site can be obtained for its erection. It is a cheap and simple structure, and a pleasing object in the landscape. In some parts of the country they are much used for various economical purposes connected with husbandry, and may be thus applied in connection with the raising of water to supply fountains or reservoirs in pleasuregrounds.-ED.

Sinelter.-It has already been remarked that situations exposed to high winds and cold dranghts are ineligible for the site of a house. The proprietor, however, has sometimes a difficult choice to make between. magnificent distant views, which add so much to the 
cheerfulness of a residence, and that warmth which results from sufficient protection, and tends so much to promote its comfort. Most likely he will endeavor to compound the matter between the two rival claims, and, while he risks some degree of exposure, will seek to mitigate it by means of shelter. It is commonly found that natural shelter is the most effectual. A hill, or knoll, or low ridge, particularly if covered with trees, is more efficacious than a plantation on a slope ascending to the house. A slight change of position will sometimes be found to have, in this respect, a noticeable influence. In an extensive park or district of country, the aërial currents generally affect a particnlar track, determined, perhaps, by a gap in a line of hills, the terminating of a ridge, or the contracting of the sides of a valley; and a small remove from that tract, which may be ascertained by observation, may afford the protection required, without much sacrifice of beanty. The site should be open, and, if natural shelter is not to be obtained, recourse must be had to planting. There are few places, indeed, except in some marine residences, in which this expedient is not of consiclerable value; still, in exposed localities, the progress of wood is slow, and one generation may pass away before the result desired can be effectually secured. Meanwhile, the builder of the house may have derived little benefit from the trees which he has planted and reared with great expense. Even for a marine residence the shelter of a large rock or knoll is of much consequence. For the sake of a dry and warm site, I should be much disposed to forego some other more showy qualities.

Note.-The question of shelter depends somewhat on the length of time, and the season of the year, in 
which the house is to be occupied. For a summer residence solely, the view or scenery which the site embraces - other things contributing to the conveniences of access and living - has usually a controlling influence in determining the question. Shelter, therefore, as the term is understood by our author, is not of the first importance. If the house be built in proper style, with verandas, and suitable yard and garden walls, aided by the quickly growing trees and shrubs, with which our country abounds, the question of shelter will be readily accommodated.-ED.

Position of the Hotse in the Park.-The relation of the mansion-house to the various points of the surrounding domain, requires attentive consideration, and yet it is a subject on which it is difficult to give specific directions. The whole circumstances connected with the locality, the surface of the ground, and the facilities of access, must be taken into account. We believe that a site near the center of the park, other things being equal, is generally preferred. Sometimes necessity obliges the choice of one much nearer the boundary; and such a position, when well protected from external annoyances, either by the form of the ground, or by the intervention of a lake or arm of the sea, or by a considerable breadth of plantation, instead of being a disadrantage is the rererse, especially when the views from the public rooms, parkward, are by that means extended both in length and breadth. This observation, however, relates chiefly to places of moderate size. In smaller parks, on account of the limitation of space, it is more difficult to form a fine piece of lawn or park scenery when the house assumes a central position; and there is generally a 
want of that depth which is attainable when it is set down near one side or end of the place. Excellent sites may often be selceted near the shore of an arm of the sea, on the bank of a lake, or in the vicinity of a river, as at these points, besides the land scenery, we have that life and variety which water ean alone afford. There are, however, few rivers forming the boundaries of estates of sufficient breadth to allow the house to be erected close to their banks. Besides the risk of inundation and of damp vapor, which is ineident to low situations, there is always the possibility of discordant or offensive objects being erected on the opposite side.

Note.-The objection to the narromness of the rivers in Great Britain is well made; but not so in America. The St. Lawrence, Niagara, Detroit, St. Clair, the Ohio, Mississippi, the Connecticut, Hudson, Delaware, Susquehannal, Potomac, and an hundred others of our broad rivers, afford the finest possible sites for chrellings, in many instances on their immediate banks, where they are of suffieient widtl to rencler " discordant or offensive objects on the opposite side" so indistinct or innocnous, as to form no serious objection to improving them for park or villa residences. A site on the immediate bank of a broad stream, or bay, or lake, will seldom be chosen, excepting in a level country, where the house would, if placed at a distance back, not command it, and where the banks are of sufticient elevation to be out of the reach of floods. Water, in connection witl landscape scenery generally, is more effectire when seen from a moderate distance, than when it makes the immediate foreground of the picture. This, however, will depend much on the breadth of surface which the water ocenpies, and whether it 
forms a part of the whole landseape, or a part only of one of the views from the dwelling, when snch drelling commands a separate riew from its different fronts. The suljert of the landseape which is to be embraced in the single, or in the several views of a residence, cannot be too closely nor too intimately studied, before determining the site for the buildings.

It may be remarked in this connection, that as no landscape view can be complete withont water, it should, when it can be embraced in the view, always find a place, far or near, as eirenmstances may control. Minor objects in wood, buildings, or extent of comtry, may be discarded for the advantage of a grand view of the water. Indeed, we know of no sensation suddenly breaking on the mind like that of a fine water view when we have been long pent up among woods and grass alone, however pieturesque and beautiful they may be. It expands the heart, exhilarates the spirits, and stirs the soul as no other natural object ean do; and-although from being long aceustomed to it we may be over-partial-we wonld not forego the daily spectacle of a broad sheet of moving, living water, for all the petty artificial gettings-np of all the artistic gardeners in the miverse- $-E_{D}$.

A more elevated position, even though it may be near some public road, will probably command equally fine views of the river, and at the same time be more free from intrusion, than any of those lower down. We may add, that eertain baronial resiclences, and some of them of no small splendor, are occasionally seen standing on the side of street or road, having been erected there beeanse they were places of strength in ancient times. Such remains of the old fendal glories 
we should be sorry to sce remored from where they are; but similar situations are now seldom or never adopted for new residences.

Note--At the risk of being prolix on this subject, we must be permitted to enter a protest on the characteristic tendency of Americans to place their country establishments in close proximity to the lighway or public road. $\Lambda$ prominent object in the enjoyment of a country residence, is retirement - shutting ourselves from the gaze and remark of the passing world, and enabling us to take our own pleasure in our own way. A familiar connection with the public road, therefore, shonld always be avoided; while the park, and the buildings within it, should still be at a reasonably convenient distance for the necessary purposes of living. A suburban villa, simply, may look ont upon the public street in front, and at a few rods distance from it; but a proper country-house, with extensive grounds around it, appropriated for the use and convenience of its occupants, should shun all such familiar contact. In fact, no family, not possessing within themselves resources of mind, and books, sufficient to keep them from yearning after the idle gossip of a village neighborhood, should ever think of living in a "park," or away from the daily intercourse of a pedler's cart, or the interesting spectacle of a passing drove of cattle, sheep, or turkeys.-ED.

Eretation of the Site.- The house should be placed on ground moderately elevated, of easy access, and commanding some of the best views of the park and the surrounding scenery. The expression, "ground moderately elevated," applies more to an undulating country, than to a level tract, or to a hilly 
or momtainons region. In a low, level, and wellwooded comntry, the effect of the mansion from withont, and more particularly the views from it, wonld be entirely lost were it not bnilt in the ligghest position to be found within the park. In a hill country, again, a comparatively "moderate elevation" wonld probably place the house among the mists and clouds, whereas it might be secured from these, or at least have the most firorable station in the district, by occupying the first or second of the lowest platforms of the valley in which it stands.

Note.-Happily, in the United States, we possess all possible varieties of elevation which the funcy of those seeking park residenees may demand, on which to indulge their preference. Our Atlantic states, from Maine to Florida, abound with those embracing beauty, picturesqueness and grandeur, of thomselves alone, or in varied combination in their most pleasing forms. And in the broad agricultural states of the west, there are natural parks, of an extent and beanty rarely equaled, and nowhere surpassed, elothed with the noblest trees, in dense forest or in open glades, meandered by pleasant streams. These, to the eye of taste, present the finest features for the indrlgence of an inclination to appropriate them to the most luxuriant parks and pleasure-grounds that ean be imagined.-ED.

Extent of trie Sity.-On und ulating or lilly surfaces the site selected for the house should always be of sufficient extent, not only to contain the whole of its buildings, but also to afford ample space for the roads, and room for earriages turning at the entrance, together with a broad walk and terrace on the drawingroom front. Inattention to these requisites will often 
lead to great subsequent expense and inconvenience. Wre have seen a fine mansion so put down between two steep banks that at its entrance there was scarcely room to turn a donkey-cart, if we may be permitted to employ a familiar but undignified comparison. At the same time, the garden front was such that it required a thick wall, reared up from a considerable depth below, to form a walk a few yards wide, in firont of a pile of buildings which would grace a terrace of magnificent dimensions. Such an error, if we may presume to call it one, was rendered excusable, or at least was accounted for, by the circumstance that it was the site of an ancient ancestral castle that was thus occupied. We cannot wonder that old feudal associations and family recollections should lead "afar descended" proprietors to cleave to some particular spot as their time-hallowed homestead. Still, we sometimes think that there is bad. economy of cherished memories in thus enveloping and concealing the old with the new. If an eligible site were to be found in the vicinity, we should rather have chosen that for the house, and liare left the ruin in its own inherent dignity:- so would there hare been two objects of interest instead of one; and the fragment of departed grandeur would have spoken directly to the eye, and not have been beholden to the imperfect medium of words for the occasional telling of its history Of course, the same excuse cannot be made for error committed in the erection of a new mansion, or in the rebuilding of one of little historical or family importance: and yet a picturesque view will sometimes seduce a man to set down a house on a narrow pinnacle, where there is scarcely room for a dorecot. Want of judgment like this is not 
unworthily repaid by subsequent expense and inconvenience.

Note.-More truth could scarcely be condensed into the same number of lines than our author has here written. Fortunately, for the exercise of a correct taste in such Americans as have the inclination and means to indulge in the recreation of park building, they lave no "feudal associations ;" and, perhaps less fortunately - for we individually confess to no inconsiderable degree of respect for family antecedents of the right kind - as a people, not a superabundance of "family recollections" to lead us into the absurdities against which he warns us. We are, therefore, left with few prejudices or partialities to warp our judgment in the situation of proper sites for our country homes. The want of proper education on the subject, and a lack of natural taste, are more frequent obstacles in the way of a choice of the best ground to appropriate to objects of luxury. Room enough in a country of cheap land, like ours, should be the first item of consideration with those who set about selecting a site for a house out of town; and for the lack of that, to one who has the means to build at all, there can be no apology.-ED.

STYLe of the House.-This is a matter which, in all its bearings, does not come within our province. The rank, the fortune, and the taste of the proprietor, are all entitled to be consulted, and to have their weight in its determination. Still, it is universally conceded that the style of the house should have some adaptation to its site, and to the character of the scenery by which it is surrounded. Much has been written on the subject, and much has been said about one style for 
the beautiful, another for the picturesque, and yet another for the romantic. The confess ourselves unromantic enough to think that a comfortably arranged interior is of greater moment to the proprietor than the finest exterior can possibly be. At the same time, a good external appearance is not a matter of trifling importance, nor is it incompatible with a good internal arrangement. A proprietor of refined taste will naturally wish that his house should mite both of these desirable qualities, and at the same time that it should be properly adapted to its site and position in the park. Before beginning to build, it is well to consider what style is best suited to the locality. Undoubtedly, the style should be selected for that site which on general grounds is considered the best, rather than that a site inconvenient in itself should be inconsiderately chosen, on account of some fancied adaptation to a particular style of house. It appears incongruous, we might almost say absurd, to place a street-looking house in a highland glen, or a castellated mansion on a plain as flat as a bowling-green. Such mistakes are not unfrequent. We may add, that the external appearance should have such a relation to the internal arrangements that the spectator on the outside should have no room for mistake as to which is the entrance front, which the drawing-room side, and what portion of it is occupied by the offices and inferior apartments. The public rooms should have some external indication, if not of their individual use, at least of their general purpose. To the improver of the park and pleasure-grounds, the external appearance of the house is always a matter of great interest, as the house is the central point to which all his operations are referred, 
and from which they take, as it were, their color. A beautiful and well arranged group of buildings constituting the mansion-house, create an interest in his mind suggesting felicitous icieas, and stimulate him to overcome difficulties, while a bald and shapeless mass of brick or stone contains few or no elements of inspiration. In regard to the former, his delight will be to bring out and heighten the features of beauty; in the latter case, he will make it his duty, so far as it is in his power, to diminish or relieve the actual inferiority which unhappily exists.

Note-For a more systematic understanding of the subject, we regret that our anthor had not postponed the discussion of the "Style of the House" until after" he had disposed of the "Pleasure Grounds" and "Parks," which comprise the next two chapters. These being discussed and understood in their several aspects, the "House" would more naturally follow, in its appropriate style and arrangement, in keeping with the grounds which are to embrace it. In other words, a house can be much better fitted to the park, than the various features of the park can be moulded to fit the house, let its style, in itself considered, be ever so inviting. Parks, in America, have, practically, a soinewhat different signification than they have in England. In England, almost every landed proprietor who indulges in the luxury of a park, has a large agricultural estate adjoining, usually farmed by tenants, together with a home farm of more or less extent, for the accommodation of his household, and to which the park is an object of convenience, in grazing his lerds, at the same time that it ministers to the gratification of his tastes and his luxury. Such appropriations 
of large tracts of ground are not common in a waste region, and the finest parks are found in the most highly cultivated connties. The buildings which decorate these grounds are usually of great extent, in elaborate styles of architecture, and cost sums in the constrnction at which even our richest Americans would shrink in the contemplation. But the park-building Englishman builds for himself and his posterity to inhabit. The American, although he may faney, or flatter himself, that he buikls for the same purpose, in a great majority of cases, after a few years of possession, either willingly alienates it into the hands of a stranger, or, enjoying it for the term of his own life, his lieirs usually expedite that transaction in as bricf a space of time after his demise as the forms of law will admit. In his design, the laws of entail fortify the Englishman. He is already in possession of a hereditary estate, which has been for generations or centuries in the family, and he builds and improres with a knowledge that, in the usual current of events, it will continue so to descend. Or, if he buy a park and build his mansion, he intends to found an estate which is to remain in his posterity, or in the collateral branches of his family, with a reasonable expectation that they will occupy it for generations succecding him. In our country, the laws, contemplating the subdivision of any estate belonging to the head of a family, perpetually admonish him to a limited expenditure in so costly a luxury, which, if he be a sensible and a prudent man, he will continually bear in mind. Under such considerations, the:efore, England, the country from which our fincies and tastes are mostly copied in subjects of this kind, althongh worthy of consideration in many features of imitation, is not, in 
the extent and costliness of her parks and houses, a safe example for the American to follow.

The style of the house for the American park, may be considered with us in two different lights: the first as appertaining to the agricultural proprietor, the second as devoted to country leisure and luxury alone. In the agricultural states, comprising those lying south, west, and nortu-west of Pennsylvania, the extent of land cultivated and occupied by many individuals, will permit them to appropriate a snfficient space to park purposes to gratify a very considerable ambition, while it may remain devoted to economical uses, and at the same time afford the finest scope for a display of good taste in landscape gardening and building. Such proprietors are usually the managers of their own estates, and reside upon them, if not permanently, at least for several months of the year. These are their homes their places of business. Their habitations are for their business convenience as well as for domestic life, and should be made altogether for everyday purposes. Choosing, therefore, to reside in a park - and which they may do with equal convenience to the management of their estates as if huddled into close proximity to their cattle-yards or their laborers' quarters - they should consult a dne propriety and style of building, within the limits which prudence in the outlay will admit, as much as the richer man of the city who enjoys his park and pleasure-grounds for the purpose of luxury, and lavishes upon them a much larger sum for the gratification of his taste or the display of his wealth.

In considering the first part of the subject, althongl it may be a fancy, there is a fitness in the structure 
of a house, somewhat comporting with the ground features of the country by which it is surrounded. A mountainous evergreen, or a hilly region in a northern climate, would naturally suggest a strong-walled house, with a steep and sheltering roof to protect it from heavy snows, and give it warmth, as in the Swiss or Anglo-Italian styles, if placed on an cminence overlooking a wide tract of country; or in the old English cottage style with high gables, in a valley protected by high hills, and sheltered by woods. If in a plain, or an undulating country, a wider choice of style may be indulged, as the more open Italian, or the modern pointed Gothic; or inclining to the Venetian, and low Italian, with broad verandas in both, as their localities extend further sonth. For the Nolman, Tudor, and Elizabethan styles, as they are sererally termed, we have less attachment, being too suggestive of fortification, and defense, for which people of the present day have no use. The indulgence of these styles witl the architects of our own time, frequently run into all sorts of absurdities in the accumulation of buttresses, gables, turrets, and endless conceits that lower the true dignity of the house, and make them more to resemble a costly toy than a sensible, comfortable dwelling. Aside from such drawbacks, we cannot with propriety copy the proportions and parts of the foreign structures which are presented to us in those elaborate styles. In adapting them to our nse, they should be Americanized, if such a word may be permitted, into a fitness to our circumstances, as being different from the people of any country abroad. They should be plain in the exterior, and simple in their composition, with every conrenience that is 
required where the inmates of a family, sare in the southern states, have to rely much more on then. selves, than in countries where society is divided into such castes as compel one portion of the population to serve the other, of necessity, and where such service can be readily commanded.

In regard to the material of which the house should be constructed, there is a manifest propriety in using that which most abounds in the vicinity, if it be of a proper kind. In a region affording good stone, being convenient, durable and cheap, nothing can be more appropriate. In the absence of stone, and good clay in abundance, bricks stand next in durability and cheapness - a fitting material always ; while in lumber districts, abounding in a choice of woods, they may be applied to the construction of houses for all purposes, and in desirable varieties of style.

Situated in a park, or elsewhere, a house should express in its external appearance its chief purpose of occupation. For summer resort only, it may be open, light, showy, and shadowy. It may be relieved of some appendances which are indispensable in a winter dwelling. It may indulge in more ontward ornament, and wear a less substantial look; for its exterior expression should show that it is a dwelling solely, and not to be mistaken for a temple, or a pagoda. A house for permanent occupation should have its one or more fronts - scarce ever more than two - and such front or fronts furnished in a style of superiority, or otherwise corresponding with the uses for which they are designed. It is to be supposed that its site commands the finest view which the park embraces, and the best front of the dwelling should look out upon it. The 
rooms on that front should be the highest finished and furnished, and deroted to the leisure hours of the fimily, to purposes of hospitality and social intercourse. Such may, under fitting circumstances, be made the entrance front, when another does not render the approach more convenient. All the show and lnxury of the exterior finish should liere be displayed; as, commanding the best and most extended riew orel other objects, it is the most prominent and pleasingt subject of contemplation from the same objects in turn. The house should show, from any point of view at which it is seen, that it has a principal front, or another firont, if it really be so; yet that this other be subordinate to the main one, for it is scarcely to be supposed that any one house can command two opposite fronts, or even a side one, in addition, of equal interest or beauty. It should indicate, also, that it has one or more sides shut off from the general view, which aro appropriated to family rooms, where the inmates may be retired; and, as a matter of course, domestic convenience demands that there be servants' rooms, kitchen, scullery, laundry, wood-honse, and other appendages, forming a continuous range of building in the rear, which should be quite shut off from familiar con. tact.with the better and more finished, and protected by shrubbery, trees, fences, and perhaps additional buildings, accommodating the stable and other requirements. These, in contiguity with the kitchen and fruit-gardens, placed in appropriate position and connection with the main dwelling, compose a picture of completeness on which the eve can rest with entire satisfaction.

There being a sufficiency of ground, the house 
should spread over it. There is no necessity, nor convenience, in underground rooms for living purposes, in the conntry house. For height, full two stories above the surfice is all that it requires; more than that gives it an ambitious look, and suggests the idea of a eity loonse in a wrong place. A broad reranda on the principal front we would not omit; it may be extended around one or more of the sides, or even, in a southern clinate, to the opposite front, if such front there be, (but not a continuons veranda around the whole, provided the style of its architecture will allow it without a riolation of its rules.

A flanking and rear of wood, composed of either fruit or forest trees, makes the richest background, as seen from a distance; and where nature has not already fiurnished the forest, a plantation of one or the other should at once be commenced. By this, the house and its appendages become, as they should be, the eye of the picture, other irrelerant and less interesting objects being shut out of sight. Such, and all such advantages may be comprised in the dwelling of the wealthy farmer or planter of the United States, without trenching on an economical arrangement of his family residence.

Let such a composition of the park mansion be contrasted with many a modern one, designed for expressly the same objects, which are so often obtruded ujon our sight : a tall, square, castellated structure, standing on a high basement, having at least two, sometimes three, and, worse still, four fronts, all equally approached by a carriage-way or font-walk entirely around it. The windows of each room staring ont upon its front, and every apartment exposed to the 
noise and intrusion of every passer-by; every door a public door, and no private iugress or egress whatever. A cellar-kitchen, with underground offices attached, sending their steam, smoke, and effluvia into every room and area above, and concentrating within the four, six or a dozen lines of onter wall, as the varions angles and zig-zag lines of said wall may govern, all the seemly and unseemly kinds of occupation to which the appurtenances of a dwelling-house are devoted! Of the style of its outer or inner architecture, no matter now - of its interior arrangement we are at this moment speaking, and it must be apparent to all who understand either the requirements or necessities of housekeeping, that it has no true fitness for such purpose. All and every part is public, and public alike-all lawn, all approach, all open, all show. There is no retirement, no privacy abont the establishment whatever. Yet many such houses, mansions, country seats, or villas, by whaterer name, are thought by some, professing to have taste and judgment in such matters, fine houses to live in! TWe have seen such, built at an expense of ten, twenty - even thirty thousand dollars, and upward, that were eclipsed in all convenient family accommodation, at a cost of half the money in each corresponding degree of pretension.

Now, to any one who will enter into the details of such an establishment, it will prore a difficult labor to trace ont the sinks, drains, areas, and what not, lcading into and oit of it, their cost in construction, the labor and rexation of living in and keeping it in repair. The stables and carriage-houses - for there are no out-honses, in the common acceptation of the term - are at a distance, either in open view, or bebind 
trees or shrubbery, as chance may govern, and all connection with gardens, retired walks, the woods and fields - a full half of the cliarm of country life - is as effectually cut off as though one lived on the opposite side of a public street. The house may be shaded on one, two, or on every side by a veranda; but what matters it? It is still cut off from immediate intercourse with the grounds which should in all propriety closely connect with and adjoin one or more sides of it, and through which should be no public passage, and only approachable through a door of the house, or a gate belonging to it. It is a show-house, in fact, erected to gratify the builder's ostentation, instead of a dwelling in which to enjoy domestic peace and seclusion.

The exterior architecture of such a house, as applicable to a dwelling, cannot be good, because there is a want of fitness in its appearance for the purposes for which it is built. To apply architectural proportions and beauty to an object like this, it should be largely extended to embrace an open court, around which its several parts should extend, like a Europen palace, a thing we have no use for in America as a private comntry residence. A moderate sized honse of forty, fifty, or sixty feet square, as large as is usually required here, with a strictly architectural finish, must look like a public structure, and then it becomes an absurdity as a dwelling. Its interior, fitness is no nearer the mark, for its convenience must yield to the demands of the exterior - a show dwelling altugether.

In the second light in which the style of the house may be regarded, as the permanent residence of the man of leisure, the scholar, the retired man of business, 
or of him who resorts to the country for a sojourn of a few months in the year, and unconnected with agricuitural pursuits, other considerations move him in its construction than those which control the agricultural proprietor alone. If he retire at the distance of some miles from the city, and out of the immediate neighborhood of a village, the man who intends building a park residence will appropriate a sufficient area of ground to accommodate his wants in the way of pasturage for his horses, cattle, sheep, and poultry, (for without them his establishment must be incomplete, and combine within his own possessions a sufficiency of wood - and water, if possible - to give a completeness to the domain within his own apparent boundaries. These accomplished, the house becomes the attractive and paramount object of his attention.

Althongh not perhaps exactly within the province of these notes to give a homily on the financial policy of house-building in the country, yet for the edification of such as look to country resiclence as a recreation, or a temporary retirement only, it may not be inappropriate to suggest some reflections when about to inrest a portion of their capital in an object so fruitful of pleasurable anticipations. There is probably no description of real cstate which is so fitful in its occupation, and so temporary in the tenure, as the country places belonging to residents in our cities. The reasons leading to this might be giren at length, but they will readily occur to any one who chooses to give the subject a deliberate thought. Some people buy a place and retire into the country without the knowledge of what country life really is - without any true appreciation of its pleasures or its sacrifices - without reflection 
upon its inconveniences or its expense. They adopt it, in short, because it is the fashion. One buys a piece of ground without knowing its capabilities for the object to which it is designed, and throws himself into the hands of his professional landscape undertaker, and his architect, heedless of their skill or fitness to execute their work. They squander his money, and put up a place - after the fashion - and perhaps before it is ready for his occupation, he becomes disgusted with the expense and place together, gets over his passion for retirement, and sells it on the first good offer, at a heavy sacrifice. Another may retain his, and try country life for a year or two, and then, finding it unsatisfactory, disposes of it at perhaps a better price than the last, and pockets the loss with the best grace he can. Another, still wiser, buys a place already built, at a considerable discount, and occupies it, intending to make it a permanent residence; but his circumstances changing, in business or family, it is again sold, most usually at a loss, for, coming into his hands ever so complete, his own propensity for improvement has inrolved an outlay of some thousands for its further embellishment, for which the new purchaser is not inclined to pay. And so goes almost the entire chapter, until there is rarely to be found a "country place" within striking distance of our principal cities, which has been occupied for twenty years by the same family, or name, and but very few for half that period. They have proved the most expensive lnxuries in which their proprietors have indulged, and are thrown off their liands like any other bauble which amused their fancy for the time, and with quite as little regret. These are facts which it is well to weigh before 
involving one's self in a large expenditure in building a country residence. An investment in land is not so hazardous a matter. If well situated and well pur chased, the loss in it cannot be much when one wishes to clispose of it, even if not valnable for agricultural purposes. It is usnally the honse and the other erections built upon it which sink the capital, and in the erent of the sale of the premises, tastes in such property usually differing, the purchaser is fastidious unless he can drive a decided bargain. Many familiar. places can be named which half rnined the owners in building them, and never gave them a moment's enjoyment in their occupation. The splendor of his dwelling can add nothing to the consequence of the proprietor in the community in which he lives, further than to identify him with the notoriety of his temporary castle; and to the man of true fame, an ambitions and costly honse counts but little with those whose approbation he is most solicitous to preserve.

We wonld not be misunderstood as suggesting a mean and parsimonions spirit in the comtry dwelling. Far from it. Every thing relating to it should be on a liberal plan - large enough, rooms enough for family and relatives, and complete in every luxury and comfort; but all for use, and not for show. Ostentation should have no abiding place in the country. Health, leisure, amusement, quiet, rural beauty, are the objects for which the country is sought by the jaded citizen, or the lover of country life. These attained, the purposes of the park and its country house are accomplished; and what these cannot provide within the limits of a reasonable expenditure in a dwelling, no amount of money can bestow. On the contrary, an 
opjosite course - the squandering of a large sum on an object which in its nature and purpose is designed as a retreat from the throng and bustle of the town, lias often defeated the rery design intended, and driven many an honest seeker of the true pleasures of rural life again into the labor and turmoil of business, from the mistakes they had made in the ontset.-ED.

Arraygemext of the Ixterior of ture Ilocse.-Tt may he supposed that the improver oi" a park and pleasure-grounds has nothing to do with the interior of a mansion, and it may be admitted that he is only indirectly concerned with it; still, both its external and internal arangements are to him matters of considerable importance, and come in fur a share of his attention, as they give a character, or at least impart a coloring, to the scenery which he may endeavor to create in the ricinity. We therefore deen it proper to offer a few lints on this subject. Every well-arranged mansion-house, whether large or small, should have two principal fronts, the entrance fiont, and the drawing-room fiont. Of the first, the main door and hall form the principal features, as the drawing-room and other public rooms should do of the second. These fronts should be on opposite sides of the house, or if this arrangement cannot be adopted, they should be at right angles to each other, with an end window or two belonging to one of the public roorins opening on the entrance front. The former arrangement is calculated to impart to these rooms a proper degree of sechusion, and to keep them, as it were, within the best portion of the dressed grounds, which should be on the draxing-room side of the honse. Another portion of the interior not unfrequently interferes with the pris acy of 
the dressed grounds,-viz., the servants' apartments. These, when on the ground-floor and under the public rooms, overlook the pleasure-grounds in a most undesirable manner. To obviate this inconvenience, the clumsy expedient of sinking them, in whole or in part, below the external level of the ground, is often resorted to; but such apartments, even when furnished with an open area in front of them, have always a damp, unbealthy look, and not only give to the edifice a mean appearance; but also seem to indicate that from some defect in its construction, it had been necessary to stick it into the ground, instead of allowing it to stand on the surface. In either position, they interrupt that feeling of retirement which is requisite to the full enjoyment of dressed grounds. Servants' apartments may be formed, with excellent effect, into a sort of wing or minor group of buildings attached to the main body of the house. Besides these relations to objects immediately contignous, the arrangement of the interior of the house should have a reference to the park and the more distant country. The drawing-room should always com. mand the finest views which are to be seen from the windows, whether these occur in the adjacent or in the external scenery. The views from the hall door are of minor importance, but they ought not to be overlooked or neglected. The house, when felicitously arranged in these respects, may be said to preside over the beauties of the place. Other considerations, indeed, may be, and often are, taken into account. If warmth rather than beauty is the object aimed at, the drawing-room front should look toward the sonth, whatever may be the scenery in that quarter, and the entrance should be on any of the other sides which nay be most sheltered or 
most convenient. Both the elements of warmth and beauty, however, may sometimes be secured by placing the family rooms toward the south, and the public rooms toward the east or west, with end windows to the sonth or north, if the finest views happen to be in these direetions.

Note.-It will be readily seen that our anthor writes for an English, Seoteh, or Irish climate, in remarking that "the views from the hall door are of minor importance." Our American clinates in summer, when fine views are most to be enjoyed, are decidedly dry, as well as warm; and the hall door, or one of them, at least, if there be two, should lead on to the veranda overlooking the best view from the house. The verancla, even in the northern states, is the most pleasant place of resort in fine weather, and in the southern states it is indispensable for the enjoyment of the open air. Thus, the hall door, in that connection, beeomes a prominent feature of the house with us; while in England, even in midsummer, it is but little used for sneh an object. For the same reason - the comparative coolness and moisture of the summer climate - we see few rerandas on the English honses. They court the sun; we seek the shade. Contrary to the text, therefore, a hall door and veranda should be on the best front of the llouse, whenever the main conveniences of the dwelling will permit them. With the other quite correct remarks of our author we entirely coincide, and with him most heartily beg every builder of a house in the country to aroid a cellar-kitehen as he would a pestilence. Such things have no business ont of a city under any pretense whatever. A rear wing to the house is the appropriate building. for the kitchen; and 
all other working departments connected with it, as well as the proper place tor the living rooms and dormitories of the servants.-ED.

Coxservatorr. - Among the rarious appendages which it is desirable that a mansion-honse should possess, none is more important than the conservatory, which, when happily placed, may be regarded as an extension of the clrawing-room, or at least, if it is in the vicinity of the house, and properly connected with it, it is of admirable convenience as a place of walking and of recreation in all kinds of weather. If possible, it should be contignous to some one of the public rooms or the corridor; if the drawing-room can be made to open into it, or communicate with it by a short corridor, so much the better; but it is most desirable that it should be easily accessible by the fumily withont their leaving the house, or dong more, at most, than passing along a glazed passage or veranda. When the conservatory enters into the original arrangements, one or other of these expedients may generally be practicable; but if it is entirely an after-thought, it sometimes happens that a suitable site for it cannot be obtained. It has wants of its own. It requires free air and open sunshine, and wonld be rendered useless were it shaded by the house. It obviously cannot stand on the northern side of the mansion; and if the drawing-room has a central position in that direction, it is evident that no immediate connection can be established between them. There is nothing, howerer, in itself, to prevent it from occupying such a site on any of the other three sides as will harmonize with the other buildings of the house, or will suit the interual arrangements and communications. In general, it is easier to 
make a good adaptation and adjustment in houses of moderate extent, than in very large ones. The eonservatory, when entered from the house, should be eonsidered as a glazed drawing-room, fitted, by its abundance of light, and its command of warmth, for the growth of fine exotie plants. Its internal arrangements should be simple, its passages of ample width, and its whole appliances should be snch as to permit a fiee exhibition of the plants without their admircrs erushing upon them or being ineommoded by them. The shelving and stages, when these are introdueed, should be kept low, so that the plants, if not below the eye, may be on a level with it, or not much raised above it. Such a position is required by many plants, as, for example, most of the heaths, eamellias, caeti, pelargoniums, ete. Others, as the fuchsias, acacias, passifloras, and glycines, are seen with more effect from below, and may therefore be allowed to grow up, or may be trained in more elerated places in the house. When the eonservatory is constructed on a large scale, the stages, perlaps, had better be omitted, and the shelves confined to the north side; and besides border's round the other sides, the eenter may be arranged into wide plots for the growth of large plants in groups or masses. A paved walk may encircle the house, leaving a border between it and the upright glass walls, and the eentral space may be irregularly divided by paths of elean gravel, which will have a more garden-like effeet than when a number of intersecting pavements are employed. The internal framework of the house should be simple, but elegant. Elaborate decoration in this department has a tendency to detract from the effect of the plants. Fine mouldings and carvings harbor 
insects, collect dust, and, as they are difficult to clean, contract an untidy appearance in a rery short time. The coloring of the wood or iron-work shonld be light, but not glaring; a shade of witito is gonerally. the most suitable, as it brings out the green of the foliage, and interferes little with the tints of the flower's. A fountain, or a gronp of statuary, is a desirable addition to the conservatory, as also a piece of rockwork for the growth of ferns and succulent plants. The heating of the internal air is, in ordinary circumstances, best accomplished by hot-water pipes, which, for the conrenience of the walks, must be placed below the floor, with iron gratings above them, to permit the immission of the heat. There is one important advantage in employing a hot-water circulation for raising and regulating the temperature, - viz., that the furnace by which the heat is supplied does not necessarily require to be close to the house, thongh undonbtedly it is the more effective the nearer it is. The boiler may be placed at the distance of more than a hundred feet without any material disadrantage, provided the pipes are laid under ground in a dry and double-cased drain, to prevent the escape of heat from the water in its passage to the honse. The external appearance of the conservatory, and its effect on the group of buildings composing the mansion-house, require carefnl and mature consideration. There may be varions positions which would suit it perfectly as a receptacle for plants, but in which any of the ordinary forms of glazed houses would have an injurious effect on the structure to which they might be appended. There is a certain amount of incongruity between almost all the forms alluded to and the architecture of our modern houses. Architects hare 
labored to overcome this diffienlty, and seldom with much success. Indeed, their efforts have generally resulted in their making the conservatory a vegetable dungeon, or perhaps at best something like a Parisian orangery, rather than a lively and genial abode for plants, which require, for their healthy and luxuriant development, more light than our eloudy atmosphere and our distance from the equator readily aftord. When made an architectural erection, it should be constructed to admit as much light as possible. If this cannot be effected while it is kept in harmony with the mansion. house, it is better to withdraw it into some secondary position, and to monld it more in conformity with its main purpose, than for architectural display. In such cases, it perhaps onght to be at once removed into the general flower-garden; but before doing so, a place should be songlit for it in the dressed grounds in the vicinity of the mansion-house, where it may be decorated with terraces and other ormaments, while it is treated directly as a glass-honse for plants, with internal arrangements as abore indicated. Wood and iron are generally employed for the framework of such honses, as they combine strength and lightness in a higher degree than any other materials. Stone pilas. ters, of slender proportions, may be introduced, to give a somewhat architectural air to the structure. The glass which is used for the sashes should be good, and free from impurities and irregnlarities, in large squares, or in panes, long at least, if not broad; for notling connected with plant-houses produces so mean and slovenly an effect as short panes of glass with a multitude of overlaps.

Note.-The facility with which conservatories are 
now got up in the United States, ought to make them an appendage to every complete country dwelling. We can add little to what is so well said in the preceding. Yet there is one benefit of the conservatory to which the reader's attention may, with great propriety, be called. Doctor Alexander H. Stevens, a distinguished physician of New York, thus speaks of the value of green-houses, in Downing's Horticulturist:

" Having for many years suffered from a pulnonary complaint, some ten or twelre years since, in visiting the green-house of Mr. Niblo, then my neighbor in Broadway, during the winter, I found the atmosphere exceedingly congenial. It abated my cough, rendered the expectoration loose and easy, softened the skin, and induced a comfortable state of feeling, approaching to exhilaration. Wishing to have such an atmosphere at command, I constructed a cold grapery, in which, whenever it has been conrenient, I have passed the hours of reading and study. The climate of a cold green-house, in a sunny day of the winter or spring, is a Florida climate, and is entirely different from that of an artificially heated atmosphere. I venture to recommend it, under unost circumstances, to pulmonary invalids, in preference to the more expensive plan of removal to the south, involving, as it does, much discomfiture, interruption of business, hazard, exposure, and entire separation from friends." - ED.

Stable-court, axd Offices.-The stables and their appendages may form a suitable part of the mansionhouse group of buildings, where the latter are not below the medium size; but when circumstances do not permit this arrangement, I would recommend for them a dry, sunny, airy situation, commanding a good 
supply of water, at a medium distance from the house, but certainly not in a prominent position in the grounds. Scarcely any thing is in worse taste than a large rectangular building, with its huge coach-house gates, central pediment, and a steeple or tower, composing together a staring object in the park, and competing with the mausion-house itself. Stables of this description are not uncommon, and sometimes they have their dignity increased by being erected near the principal approach. While the stable-offices should be of easy access, they ought always to be placed on the secondary approach or back road. A conrenient site for them may frequently be found on the edge of the pleasuregrounds, where they should be wholly or partially concealed by plauting. A walk leading fiom the house through the grounds, and passing near a private. entrance into the stable-court, will be found a great convenience. It is not unusual to combine the stablecourt and farm-offices into one square. The arrangement is not a happy one, particularly if the farmoffices are extensive and near the honse; and it becomes most inconvenient should the home farm be let, as it sometimes is, for in that case two masters and two sets of servants caunot long remain on good terms. Several instances of this misarrangement and its consequent annoyances have fallen under my notice. As a general rule, the farm-offices should be kept at as great a distance from the mansion-house as the convenience of the home farm, and the easy access of the proprietor will permit.

Note.-The stables should be within convenient call of the house, say from one to two hundred yards, and if possible, in a sheltered place on the leeward side, to 
avoid the swarms of flies with which they abound during the lieats of summer, being blown toward the dwelling. The stable-grounds should be of the driest description, and if not naturally so, they should be thoroughly underdrained, to pass off all superfluous water. Neither horses nor cows can be perfectly healthy on damp grounds, or in buildings standing upon them.-Ev. 


\section{CHA.PTER II.}

THE APPROACH.

Definition - Direction of the Approach - The Site of the Entrancegate-- Style of the Gate and Lodge - Line of Approach through the Park - Gates on the Line of Approach - Formation of the Approach-Roadway of Approach-Decoration of Approach-The Avenue - The Fine Approach.

As Approach is a road leading from the principal highway of the district, and passing through the park and dressed grounds to the mansion-honse. It is not to be considered as identical with the avenue found in some old places, which latter is an alley or straight road running between parallel lines of tall trees. The term approach, in its general acceptation, may denote every kind of access to the honse; in common insage, however, it is mostly restricted to the principal one. In districts where there are large forests or extcusive pasture-farms connected with the estate, the external highway may be so private as to assmme the character of an approach, and as such unay require to be dealt vith on the principles of landscape-gardening: at present it is proposed to speak of the approach only as internal to the park. In the estimation of some, the approalch occupies a primary place in the arrangement of a comitry residenec. It is probably suflicient, in almost all cases, to allow it a third-rate position in the seale of impertance. The site of the house, as related to the park 
generally and to the leading road of the district, clearly oughit to hold the first place, and the second may be safely conceded to the pleasure-grounds and flowergardens. These points, indeed, should not be determined irrespectire of the approach, a not uncommon mistale in the opposite direction; but in forming a general idea of the whole place, and particnlarly in the construction of the roads, care should be taken that the sitc of the house and the seclusion of the adjacent grounds should not be sacrificed, as they too often are, to the vanity of having a fine approach. In most eases, there is no great difficulty in making a good approach, at least when the house, office, gardens, and pleasuregrounds have been properly arranged; but when these objects have been ill-assorted, the work is far from being an easy one, especially when the house has been set down with its principal entrance to the south, when it should have been to the north, or toward the east instead of the west; or when the kitchen or other offices are attached to the wrong wing of the house. Such misarrangements may be said to be of daily occurrence, and they often present almost insuperable obstacles in the way of properly laying out the varions parts of the grounds. These arise from the circumstance that no definite plan of the place has been formed, nor even a. general idea of it conceived, till after the site of the house has been fixed, and perhaps the work of building has been partially, if not completely executed. The proprietor then begins to think low he is to get to his house; he at length perceives difficulties in the formation of the approach, which render professional advice desirable, and applies for it when it is too late, or when all that the utmost ingenuity can effect is a decidedly 
inferior line of approach. To avoid these errors the garden artist should be consulted almost as soon as the architect, or indeed, at the same time. We have no intention of disparaging the professional position of the architect, which, in relation to the honse, must be admitted to be primary and all-importart; but as connected with the honse, he has generally some ideas respecting the approach which we must be allowed to say should be received with cantion. He naturally would make the approach the means of showing off his own work, sometimes not judicionsly eren in reference to that object, and very often at the cost of sacrificing all the rest of the grounds. We camnot wonder that he should overlook that of which he has seldom any conception; but it is to be regretted that, on that account, a fine place shonld be deteriorated. Gentlemen who do not need professional assistance should make themselves sure that the requirements of the approach are bronglit in some degree into harmony with those of the mansionhouse and the grounds, before the building operations are commenced.

Note. - To bring all the features of the park into harmony, one with the other, after the ground which is to compose it is decided on, the whole subject, in all its combination and arrangement, should be made a study for months before the work of its cutting up and formation is commenced. The topography of the ground in all its peculiarities, should be perfectly familiar to the planner of the park, and to the architect of the buildings, that each may harmonize with the other. In the struggle for supremacy in showing off his own art, each in his own particular department, it would not be strange if the landscape-gardener and the architect 
should sometimes be at issue; but in all such cases the practiced eye of the proprietor, or a competent judge in such matters, shonld at once settle disputed points.

The "Approach" is of no consequence, as giving a continunus view of the mansion. On the contrary, it savors of ostentation in the proprietor. A striking glimpse from a turn or two in the roadway leading to it, is all that is necessary to impress upon the risitor the commanding position of the dwelling as the chief feature of the concern.-ED.

Direction of the Approacir.-The position and direction of the principal approach, in respect to the surrounding country, are subjects which require mature consideration. When the nature of the ground and other circumstances permit, it should lead toward the house from that side of the park on which the nearest city or town of the district is situated, this being the direction in which the greatest number of risitors may be expected to arrive, and in which the social relations of the proprietor will cause him most frequently to travel. Railways, howerer, have now become means of communication of equal, if not superior, importance to the public roads; and hence facility of access to railway stations is more frequently sought for, and in many cases secondary approaches are, on that account, being converted into principal ones, and even new ones formed. In new places this necessity should be talen into account at first; and if the principal approach cannot be made to afford a good and ready way to the railway station, as well as to serve the general purposes of the mansionhouse, a second, scarcely inferior to the other, must necessarily be formed. Independently of railways, a second or even third approach to the mansion-house, 
through extensive parks, is often needful to open up communication with the different districts of the surrounding conntry. When the second approach is of nearly as much importance as the principal one, similar care and attention must be expended on both. If the second and third are of quite a subordinate character, one of them should form a convenient road to the offices and gardens, while the other may be prolonged to some extent as a drive through the park. In places of limited dimensions, a second approach and a back-road to the house may be usefinlly combined. The back-road to the house and service-roads, when well arranged, contribute much to the domestic convenience of the residence. They should connect the house, stables, kitchen-garden, the home farm, and the more frequented roads of the external country; and they should be such that the cartages between these various places should never be bronglit along the principal approaches, nor do more than cross them when necessary. Though.kept in good order, the appearance and position of these roads should clcarly indicate their use.

Note--As a general rule, in the United States, the fewer "approaches" tlirough a park, the better. They are expensive to make, and expensive to keep in repair. Still, in well-kept places, the main approach should not be inade subservient to common and laborious uses. A hidden - so far as may be - roadway should accommodate the latter, and, if possible, never interfere with, or cross the other, when it can be avoicled.- $\mathrm{E}_{\mathrm{D}}$.

Site of the Extrance.-The entrance-gate, and its necessary appendage, the lodge, form the commencement of the approach, and a suizable site for these, 
and an easy access to them, require attention. Their position is so often governed by the relative direction of the public roads, and by the boundaries of the park, that I deem it necessary to refer particularly to some of the best and worst arrangements regarding them. When the public road joins the park wall at right angles, or mearly so, and then branches off to the right. and left along that wall, the gronnd being level or having a gentle rise toward tle park, an entrance-gate placed opposite the junction of the two roads will occupy one of the best and most imposing positions. If the road forms a single rectangular bend where it meets the parc wall, this spot affords an excellent, thorgh perhaps a secondary position. But when the road and park wall come together at an acute angie, their point of contact is perhaps the worst place that can be selected for an entrance, as it seldom admits of proper arrangements, and should be chosen only when the nature of the ground makes it absolutely necessary. When the first and second positions above mentioned cannot be obtained, we would recommend a plan equal in many respects to the second, viz., the selection of a suitable position for the entrance-gate on the side of the turnpike road, and the placing of the gate in a recess, at such a distance from the center of the road as will permit a carriage to be easily driven through it. Such a site will often be found more conrenient than one of greater pretensions. In the case of suburban residences, there is generally little scope for the selection of a site for the entrance. Frequently the scanty space admits of nothing more than a gaieway in the boundary wall. The entrance-gate to baronia! residences, in the neighborhood of towns or villages, 8* 
is most advantageously set down at the end of one of the leading roads or principal streets. When it is removed to the outskirts of the town, or to a distance from its natural locality, for the purpose of securing a long approach, it is apt to suggest the ideas of artifice and unnecessary straining after effect.

Note.-The site of the entrance to a fine park should not strike off abruptly from the highway, as if by accident. It should be withdrawn from immediate contact with the main traveled road, by throwing out a sufficient area of the grounds to common use, to render the approach to the gateway easy and natural. No stint of room, or parsimony in wall, should indicate any thing but a liberal appropriation, in all that concerns the proprietor. The entrance should look inviting; and that can never be when the gate and the walls adjoining it are pinched up close up to the line of the highway, or turn at a short angle in a dodging direction, like the hole of a fox, as if in fear that some one should find it. There should be quite as much an expression of dignity and character in the entrance to the park, as in that of the grounds and buiklings within it.-ED.

Style of the Gate axd Lodge should be regilated by the extent and character of the residence as a whole. The common rule has been, that the style of the lodge and gate should follow exactly that of the mansion-house. Perhaps there is no absolute necessity that it should be so, particularly when the buildings supposed to be compared stand at the distance of one or two miles from each other; nevertheless, there should be no markicd opposition between the respectire styles. A Grecian lodge and gate will 
not prepare one for a Gothic or Elizabethan mansion. Mrr. Gilpin well remarks, that the style of the lodge and gate should be made suitable to the local position in whtch they are placel. Were this always the casc, their effect would be iess open to criticism than it troquently is. We may add, that there should be an visible harinony, not only in style, but in importanee, between the gate and the lodge; for the one is often sunk by its marked inferiority to the other. Sometimes, when referring to the principal entrance into a park, one hesitates to speak of the gate or of the lodge, from the relative want of importance of the one or the other of them. Although the gate is the principal object, and the lodge only an accessory appendage, in designing them the result aimed at sliould be a united and well-balanced group. When the approach is short, there is a greater necessity for an exact similarity of style between the entrance-buildings and those of the mansion-house. The gate should stand at right angles to the line of the approach, and should be placed sufficiently back from the center of the public road, when one passes in front of it, as not only to enable a carriage to stand clear of the road and the gate while the latter is opening, but to turn easily into it. It also conduces to convenient attendanee on the gate, that the lodge is furnished with a window whicl ${ }_{1}$ commands a view of a carriage coming from the house some time before it reaches the gate.

Note.-The prevailing fault in building gates and lorges, is in the effort at too ambitions a style of architectirle, and a consequent expense in the structures themselves. The gate should be in keeping with the main inclosure, both in strength and costliness; so, 
also, with the lodge. It is the habitation of a dependent. It should ape no ostentation, nor have expensire fittings. Yet it should look like a dwelling, as it is, with all the little conveniences for tidy and comfortable living. The attempt, sometimes seen, at building a gate-lodge in the similitude of a temple, or other fantastic pretension, is but little above ridiculous. Utility, in all such cases, is the controlling feature of beauty, as well as propriety.-ED.

Line of the Aprosoncil throvgin the Park.When a judicious site for the entrance-gate has been selected, a good starting point for the approach has been obtained. After passing the gateway, it should proceed at right angles to the line of the gate for a short distance, the length of this part being regulated in some measure by the nature of the ground and the extent of the park. It may then turn off toward the mansion-house, in a line, of which we may remark generally, that though it may not be the shortest that can be formed, it should certainly not be unnecessarily prolonged. A straight line, it is well lnown, is the least possible distance, and persous in haste naturally take it; except on level surfaces, however, it can rarely be adopted, even on the public highways, where rapid locomotion is most desirable, and considerable detour's are often made to avoid the retarding effect of steep inclinations. In the park, as now laid ont, the straiglit line is seldom employed, as it cannot be introcluced withont a stiff and bald appearance. On the other hand, an approach two ol three times longer than necessary may be regarded as palpably absurd; and not less so is an approach which is, for any reason, led oror steep and difficult ground, when perhaps an 
easier line spontaneously suggests itself to the observant traveler. The exhibition of fine views is a temptation to commit both of these faults; but it is a temptation which should be resisted. While the approach niay display the average beauties of the place, it is bad taste, as well as bad economy of pleasure, to lengthen it out for the mere purpose of showing the extent of the park or displaying the prospects which its best points may be made to command. Such waste, as it may be justly called, should rather be avoided. The extent of the park may well be left to actual inspection in rides taken for the purpose; and the finest views should be reserved for the principal windows of the house, for rustic seats or other stations in the dressed grounds, or for walks or drives if these be necessary. In forming an approach on level ground, it is proper to introduce a few easy sweeps or curves round groups or clumps of trees: these we prefer to the dull insipidity of one great uniform sweep, which scarcely any planting or other means of decoration can relieve. On rising and undulating grounds, those approaches have the most elegant effect whose lines harmonize best with the natural curves of the surface. In such cases all cutting and embanking should be aroided ás far as possible. Nothing can be in worse taste than to cut through a hroad swell of ground of small elevation, or to bank across a wide hollow whose surfaces vary only two or three fect, for the purpose of forming a level road, or what may be called some imaginary gradient. When cuttings and embankments are unavoidable, as they may be on short, abrupt, rolling undulations, or steep surfaces, they should be rendered as inconspicnous as may be. Easy 
inclinations in all cases are extremely desirable, and to obtain these on rough ground considerable sacrifices must often be made, both in adding to the length and diminishing the beauty of an approach. Into this species of work, however, the furor of railway-making has introduced some of its most violent operations, and has added very little to approaches, as good roads, while it has taken much from their agreeableness, as good drives through a park. Before proceeding to blast rocks with gunpowder, or to cut into or through ridges, it is well to see whether we cannot save expense and the beauty of the ground by deviating a little to the sight or left. One of these new approaches, formed in deftance of all such considerations as those now indicated, and executed by a ci-devant railway surveyor, has been, not unaptly, styled by observant neighbors, "The Lodge and Stables Direct line," from its passing close by the latter offices in its way to the house. In this case, however, there are probably more faults than cutting and embanking. A well-laid-out approach will seldom be made to cross the park on the drawingroom front of the house, in its way to the principal entrance. It is desirable, howerer, that the honse should be seen from it in one or two advantageous positions, and that it should be in part visible from the windows of the public rooms, in order that the inmates may perceive the approach of visitors. If there are circumstances which make it unavoidable for the approach to pass the drawing-room front, it should be kept at such a distance, and conducted at such a level, as to prevent the dressed grounds from being overlooked.

Note.-The approach should arrive at the house in 
the easiest possible way, curving ronnd the hills, and avoiding the hollows - shunning cuttings and fillings alike. It should, on breaking into the finer grounds adjacent to the honse, rather surprise the stranger at the magnitude and grandeur of the place, than to show it only as he had fancied it from the glimpses he had canght in his passage up. We have seen places which struck ns with disappointment on arriving at the main points of attraction, from their less imposing character, in reality, than they showed when approaching them from the entrance. The view from the house should, if possible, surpass all others; or, if not, the grand view of the place should not be an every-day affair, to be stopped for, and gazed at as the lion of the establishment, at any one point in the usual approach. It should be apart and by itself, to hold divided empire with nothing else on the premises.-ED.

Gates ox the Lixe of tire Principal Aprooaci.Gates interrening between the entrance-lodge and the main door of the house should, generally speaking, be aroided. They either betoken some want of skill on the part of the designer, or they are the result of some mal-arrangement of the subdivisions of the park, or, perhaps, of additions to the dressed grounds. The only exccptions to this rule are the cases in which parks and pleasure-grounds are rery extensive. In

- such circumstances, secondary gates and lodges may be necessary. Eren in small residences, when the approach cannot be protected by a fence, the whole way to the main door of the house, a light iron gate may be required to defend the piece of lawn or ornamental ground before the entrance-front. The subdivision of the park for grazing purposes, is the 
principal source of the gate muisance on the approach; but it may be abated by the use of wire fences, used as divisional fences, and made to run parallel to the line of the approach, in which case they interrupt the continuity of the park in a very slight degree. They should be kept back from the road, at least fifteen or twenty feet; and the grass growing on the intercepted space may be cut for hay or eaten down occasionally by sheep. We have found such an arrangement extremely useful in a park where the approach passed through a wood, pasture-lands, and pleasure-grounds, for the length of a mile, without a single gate.

Note-We can see no necessity or propriety for subdivision fences, or gates, within a park, unless on extensive agricultural estates, where they may become indispensable for the conveniences of cultivation, or pasturage; and in such cases, it is worth some pains to ascertain if they cannot be avoided. All cuttingsup of the grounds, by "fences, hedges, or otherwise, mar the dignity of the places. Apparent extent is a chief feature in a park proper; and if this be sacrificed to the common checker-work of farm fields, better make a farm of it at once, and place the house in a well-kept lawn, with its tidy inclosure of wire fence, or paling, to protect the shrubbery and flowers which appertain to it, rather than pretend to park the place, and leave it, after all one's effort, a failure.-ED.

Termination of the Approaci.-That part of the approach which is nearest to the honse, and comes up to the entrance, requires very careful adjustment. When the ground is level, a suitable termination is comparatively easy; but in other cases, cutting and filling up of the surface may be needful, before access 
can be had with a gentle inclination to the hall door, or a sufficient breadth of level surface can be formed in front of it. Almost every case has some peculiarity of its own. There should always be a level platform of gravel of sufficient breadth to allow carriages to turn on it. When this platform is small, it is very desirable that the adjoining portion of the approach should be level. When the nature of the ground adinits of it, the platform should be extended, and its exterior portions should be laid down in grass. Where the ground slopes rapidly from the entrance-front, it is proper to support the platform by an ornamental wall or balustrade. The approach should, if possible, never descend toward the house, without a considerable space of level ground intervening between the lowest point of the descent and the entrance-platform. Any visible descent near the house alrays imparts to the latter a mean and inferior appearance.

Roadwar of the Approach.-The road, to have any thing like a tolerable appearance, cannot be less than twelve feet wide. From twelve to sixteen feet may be regarded as a medium breadtli; but it may bo necessary to make it as much as twenty feet. A long, narrow approach, through an extensive park, has very much the look of a footpath. The road should be well formed; for, though it may not be subjected to the burden of heavy cartages, the carriages that pass over it are not always of the lightest description. Besides, in addition to its being a good road, it should also be a gond walk, and this cannot be effected without its being finished in a smperior manner. The road way should Lave its bottom paved with hand-packed stones, from four to six inches deep; over these should be placed 
four inches of rather small road-metal, blinded with two inches of fine gravel. If gravel cannot be had, five inches of road-metal will be necessary, and two inches at the top must be broken fine. In certain districts there is abundance of what is called rotten rock, or beds of rock partially decomposed by the action of the atmosphere, which supply an excellent blinding material. The road should be rounded by being raised in the center two or three inches above the sides. In damp situations, small drains should be formed along each side and below the roadway. Where the roadway has a hard bottom, that is, when it is cut through rock or firm gravel, the packed stones may be omitted. It is good economy to make a thorough road over the whole breadth at once, as carriages do not always keep the center, and are sure to break down that part which is insufficiently constructed. The secondary and other service-roads in the park should also be well made, though they do not require to be so fincly finished as the approach. It may be laid down as an axion, that well-made roads are most easily kept in order, and least expensive in their after management. There chttings and embankments are required on approaches, several feet of level space should intervene between the road and the bottom of the slope down to it, or between the road and the upper edge of embanliment which supports it. In both cases the newly-formed slopes should be rounded so as to unite as far as possible with the natural curves of the ground.

Note.-This road-making is an expensive business in America, and where it is of considerable extent within a park, may cost more than the house itself. By the aid of thorough under-draining - and under- 
draining is not very expensive - a good road may be made, even on heavy lands, with the soil orer which it passes. All water-courses running across them should be well and highly bridged, and carried away as directly as possible, and the side ditches turned off at every convenient oppertunity. The manner of laying out the road, or approach, as spoken of in a preceding section, will materially affect the cost of making and keeping it in repair.-ED.

Decoration of the Approacir.-Much ornament by means of trees and shrubs is not required in the approach, although a moderate degree of embellishment may be considered necessary, and its amount should be regulaterl by the extent and character of the domain. Generally speaking, nothing more of this kind is needful than what belongs to the entrance-gate, or the particular portion of the park or dressed grounds passed through. In relation to this point, and particularly in regard to the exclusion of exotics, a good deal of finical pedantry has been exhibited by writers, who seem to have forgotten that the larch and the horse-chestnut were exotics in the early part of last century. It may be concerled that rhododendrons, lilacs, and other flowering shrubs are out of place in the open park; but these plants are out of place, not because they are exotics, but because they are associated with the ideas of culture and keeping which, in the situations referred to, they are sure not to receive. It is certain that good approaches are often spoiled by excessive decoration. Such is particularly the case when they are separated from the pastures on each side by slender or temporary fences. The slight restraining effect which these fences have on the continuity of the park is much angmented 
when shrubs are planted along their edges. Certain circumstances, however, no doubt warrant a greater amount of ornament than we have considered to be generally necessary. The approach, on its way from the entrance-gate to the mansion-house, may pass only through woods and pleasure-grounds, or at most may only skirt the grass lands of the park, and be separated from them by permanent fences. In these situations the sides of the approach, except where they are narrow stripes, afford available space and opportunity for collections of exotic trees and taller shrubs; but dwarf shrubs, unless required for the completion of an arboretum group, should be reserved for the flower-garden. Note.-We are delighted at the good sense of an anthor who ignores the affectation so ambitiously practiced by many landscape-gardeners, in sticking a park full of the meaningless things which have no fit place other than in an arboretum, or on the smoother grounds about the mansion. The outer park is nature's own dressing-room, filled with robes, ample, full, and flowing. There let the trees and shrubs native to the place have wide sweep in luxuriant profusion. If they be meager in variety, it may be filled with other kinds, but equally natural to the soil and climate. We have seen a long road, throngh a comparatively wild park, bordered with choice roses, vines, and shrubbery held up by trellises, and protected by railings, all out of place, and good-keeping. Such should be for the lawns, and pleasure-grounds, and they have no business ont of them. The natural tree, the rugged rock, thie tumbling stream, the quiet lake, and the tangled brushwood, are features which mosic attract, and specially belong to the park alone.-ED. 
Tre Arexue.-In a previous page it was said that the arenue is a species of approach, leading toward the house in a straight line, and bordered by parallel rows of trees. It may be asked, when is this form of approach to be adopted? and what is to be done with it when it has been established? These questions are answered in our observations on the park, along with some remarks on the relation of the arenue to the general scenery of a place. At present it may be enough to say that avenues are most effective on flat surfaces, and that it is only on these, and perhaps on ground with a slight and uniform inclination, we can recommend them to be in any case planted. If the undnlations of the ground are but slight, open avenues may still be admissible; and these open avenues, when connected with the lawns of the mansion-house, should be of considerable breadth. When, however, they are formed as approaches, their width should not be greater than the height to which the trees forming them usually grow - say sixty or seventy feet for common elms, planes, and limes, and from serenty to ninety feet for beeches and English elms. If wider, they will be deficient in that stately and imposing effect which is the principal charm of an avenue. The open variety requires double rows of trees on each side; and if these are planted at twenty or twenty-five feet apart, they form subordinate close avenues, like the side aisles of a Gothic church, and afford spaces for charming shaded walks. The usual effect of the arenue in the park is to divide the landscape; and this, indeed, is the principal objection to its adoption, as in this respect it is almost totally inconsistent with the modern style of laying out grounds. There are sometimes positions near the entrance-gate 
where it can be introdueed with good effect; and it may be employed without injury to the scenery when the approach passes through a wood. In our judgment, nothing is more miserable than the taste which converts the bare, ill-grown trees of a hedgerow, which has bordered some parish road, into an avenue through whose narrow, irregular line an approach is made to pass. Certainly these stunted deformities should be prevented from dividing the landscape by the dividing stroke of the woodman's axe.

Note. - We have no response, otherwise than to add our emphatic concurrence in so sensible a conclusion.-ED.

The Fine Approach.-The species of access to a mansion-house which we have ventured to call a fine approach is seldom found connected with large residences or extensive estates, but not unfrequently with such small places as require only one approach and a back-road. We may describe it as a carriage-way from the entrance to the house, so laid out as to display all the principal views and leading beauties of the place. It leaves nothing worth looking at to be seen from the windows, and it renders all further inspeetion from walks or gardens unnecessary. It is in itself a thing of primary importance. Indeed, nothing can rival its ambition, except, perhaps, the vanity of the individual to whom it owes its formation. These approaches are often unnecessarily prolonged. We have seen them following the boundary of the property to a considerable distance from the entrance, the only objects between them and the public road being the park wall and a belt of shrubs quite insufticient to deaden the noise of earriages outside. In other places they 
may be seen extending for a mile or more through a narrow stripe of trees planted on the sloping banks and knolls, on the side of a small valley or of a wide glen along which the public road passes. This is, indeed, the favorite position of the fine approach. The lighest powers of the designer, who is rash and inexperienced enongh to mndertake the work, are called into exercise. Cuts, and curves, and gradients, and embanliments, are all elaborated for the purpose of enabling the approach to occupy the principal points of view. In the limited grounds no room is left for the formation of a good walk. The approach is walk, and ride, and everything. Seclusion there is none, except that the fine approach is not much frequented, people familiar with it often preferring to go by the back-way to the house. It is erident that in such elaborations the proprietor. thinks more of securing the applause of strangers than of consulting his own comfort and convenience. He is content to admire and enjoy by proxy. In short, of all the follies committed in the laying out of country residences, the fine approach may be allowed to wear the crown.

Note.-According most heartily with our author, we have not a word to say at variance with his views on the affectation of which any one who chooses to indulge in the vanity of a "fine approach" may be guilty. It is a fortmate circumstance that in this country, all the elements constituting the attractions of parks and pleasure-grounds are to be found ready made to our hands; and they are showered around us with a profusion which renders a choice easy, and comparatively unexpensive. It is, therefore, in a sheer wantonness of prodigality, and an entire absence of sound taste, that 
he who wishes to enjoy the luxuries of a fine park, and its pleasure-grounds in their natural connection, will seek by any other process than in following out the agreeable natural features of the place, to create them into a fitness to his purpose. Bare spots may have to be clothed with trees and shrubbery, mnsightly places may have to be partially leveled, or filled, and waste places made verdant; but no violence to the prevailing features of the adjoining territory shonld be attempted. It should look, when the hand of man has improved it, as if nature herself might have done the same: that man had only washed her face, and comberl her hair, and given her a more attractive garb.-ED. 


\section{CHAPTER III.}

PLEASURE-GROUTDS AND FLOWER-GARDENS.

Pusition of the Pleasure-grounds - Composition of the LandscapeTerraces - Walls - Grass Slopes - Shrubs on Terrace-banks - Stairs or Terraces - the Upper Surface of Terraces - The Flower-garden Site of the Flower-garden - Ground Color - the Parterre - the Rosary - the American Garden - the Mixed Flower-garden - Artistical Decorations - Rockworks - Shelter of the Flower-garden - Walks in the Pleasure-grounds - Formation of Lawns.

UNDER the designation of pleasure-grounds or dressed grounds are comprehended those inclosed spaces within the park, and in immediate connection with the house, which receive regular keeping and dressing. In ordinary circumstances, their walks are cleaned and their lawns are cut two or three times each season, and the leaves which fall on them are cleared off every winter. Desides the amount of labor thus bestowed on them, these grounds are further distinguished from the woodlands of the park by the quantity of shrubs, both evergreen and deciduous, which they contain, and which make up the bulk of their underwood.

Position of the Pleascre-grounds. - These grounds should be so placed as wholly or partially to surround the mansion-house. We would have said wholly, were it not preferable that the entrance-front should be in a great measure open to the park. When the entrancefront is inclosed, it should only be for the protection of the gravel and lawn in the immediate vicinity of the 4 
house. The extent of this gravel and lawn will, of course, be regulated by the size of the whole place. It is seldom expedient to have much lawn in front of the mansion. Generally speaking, it is better that the grazing lands of the park should ocenpy this position, and that the scenery on this side of the house should partake rather of the character of the park than of the pleasure-grounds. Being limited, then, on the entrancefiront of the house, the pleasure-grounds, on the drawing-room front and on the other sides, will receive a proportional enlargement. Their actual extent must be determined by the mature of the ground and the size of the park. Perhaps they may include all the space in the vicinity of the house, with the exception of that on the entrance-front, from which may be had the finest views in the park and in the surrounding country. These viows add much to the interest and variety of the grounds. If there are few or no prospects of this kind, the greater is the necessity that the pleasure-grounds should be so laid out as to awaken interest and to afford gratification within themselves.

Note-We must dissent from our anthor in his recommendation of "surrounding" the house with the pleasure-grounds. No country house ean be complete in its arrangements without an area of ground, of some extent in the rear, inclosed and shut in from the observation of strangers. To say nothing of the convenience to servants in the performance of their various daily labor's, a part of which are almost indispensably out of doors, access to the house-offices in the rear, witl provision, wood, or coal wagons, and a convenient contiguity of the out-buildings, demand a retired 
ground set apart for domestic use. We have remarked more fully upon this in our previous notes on the position of the house in the park. With such exception, we quite concur in the views so properly expressed in the text.-ED.

Composition of the LANDSCAPE.-The views which it is desirable should be possessed from the honse require a varied arrangement of the dressed grounds. As formerly stated, those on the drawing-room front should, if possible, be the finest. Sometimes they may all be included in one prospect, the pleasure-grounds forming the foreground of the picture, and the park and exterior country making up the middle-ground and the distance respectively. In certain cases, the whole scene is necessarily confined to the pleasuregrounds and park, and in others entirely to the pleasuregrounds; but whatever be the extent of view, on the proper arrangement, and on the blending of the different parts. of the scene, will depend the success of the landscape-gardener in the operations committed to him. It is evident that, with such diversified materials and appliances, a diversity of treatment will be necessary. When the middle-ground and the extreme distance of extensive views are of a varied and interesting character, it is seldom expedient to introduce much ornament into the foreground; but if the middle-ground is tame and the distance minviting, the interior should be made as ornamental as possible; and the same effect should be aimed at when the middle distance is disfigured by disagreeable objects which cannot be wholly excluded or concaled. When the whole scene is within the park, and still more when it is wholly within the pleasure-grounds, it must receive the more careful 
attention, and be so dealt with as to produce the best effect that the character of the locality will allow. When the views from the honse are extensive, it is not needful that a large extent of pleasure-ground should be spread ont before the windows. Such breadth of dressed ground throws back the pasture-lands of the park, and either conceals or renders indistinct those groups of living and moving objects with which it is tenanted. Herds of deer or of cattle, and flocks of sheep, impart much animation to the scene, which should not be lost if it can possibly be preserved, much less should it be artificially excluded. The pleasure-grounds, as seen from the house, should be formed into lawns, interspersed with groups of trees and shrubs, either separate or combined. Flower-beds may be formed in some positions, especially where the view does not extend into the park, and along with these a fountain or pond with a jet d'eau, or an artificial lake, may be introduced with good effect. Flower-beds are very suitable on a terrace near the house. A small flowergarden, in connection with a boudoir, is also appropriate; but a flower-garden on an extensive scale should be reserved for a separate division of the pleasuregrounds. In open spaces in the grounds, detached flower-beds appear to be objectionable, as they do not mass well with the other groups, as they lessen the breadth and interrupt the continnity of the lawns, and being bare except during a few months in summer, are but seldom in a really ornamental state. At the same time, a flower-garden, in a proper situation and at a reasonable distance from the house, is a most desirable object of interest, inviting frequent visits and affording agreeable walks; and, indeed, extensive 
pleasure-grounds can scarcely be deemed complete without one.

Note.-In the composition of the landscape, every agreeable object which the eye can reach should be embraced. A range of far-off hills or mountains, or a single bold peak of either, even if a partial cutting away of the park forest be necessary to reach the view, will add greatly to the interest of the scenery. An expanse of water, bounding the vision in the distance, gives a grandeur of expression second only to mountains, and when conpled together, like a high promontory shelving down into a broad lake, a wide bay, or the open sea, or a range of monntain beyond the water, they form the most perfect combination of boundary to the landscape.

- In all cases where the park proper approaches the house, nothing, after the due disposition of trees with their intermediate vistas and glades of open grass, adds so much spirit, life and character, as herds of cattle, and flocks of sheep. Deer we exclude from American parks, as being too expensive and ungovernable within such inclosures as we can usually afford. They may be kept in narrow grounds secured by high walls, or fences; but the scantiness of such arrangement would detract from the effect which animals of that character are intended to produce. A wide scope, and a free range are required by all semi-wild animals, and witlr ont them their appropriate interest is altogether wanting. A herd of short-hormed cattle, in their imposing massive forms, and beautifully intermingling colors; or a group of clean-limbed Devons, with skins of deep mahogany line, and graceful contour of body, will throw a picturesque beauty over the grounds that nothing 
else can equal; while scattering flocks of the dark-faced southdown, or the white-bodied, broader form of the long-wooled sheep, quietly nibbling on the knolls, or reposing in the shades, will fill up a picture of perfect repose. Or, if a sheet, or stream of water lie within the park, in the absence of the swan, the white or brown China, or the great African goose, with their high curving necks, and clarion cry, are objects of charming interest, as they sit or swim gracefully upon its surface. Indeed, no park scenery can be complete without choice cattle and sheep; and where water is added, its web-footed tenants, to enliven its preseuce. Such are the objects which give life and interest to the park and pleasure-ground. The common, ill-bred cattle, sheep, and geese of the country, give no ornament to any lighly-kept ground.-ED.

Terraces.- When well arranged and adapted to the character of the locality, terraces are excellent and highly ornamental accompaniments to the mansionhouse. As seen externally, there are few objects which add so much dignity to the house, as they form a finc outwork and extended basement, and impart a stately effect and an imposing breadth to the whole group of buildings. They also afford an admirable ontset to the work of decoration in the vicinity, and serve to connect the house and the grounds in a manner which conld hardly be accomplished by a lawn, however highly ornamented. Internally, they may be made a good architectural foreground to the scenery as viewed from the louse. They may also be used to conceal a one-sided slope, or a twist in the ground, which may have a disagreeable effect as seen from the windows. To a house situated near a steep, abrupt declivity, 
terraces with suitable walls may be not only ornamental, but almost indispensable to the protection of the inmates when walking in that part of the grounds. Without them, indeed, in such situations, scarcely any thing in the way of ornament or convenience can be effected. The adoption of terraees should be suggested by the nature of the ground and the character of the house, rather than by any considerations immediately conneeted with themselves. Nothing is worse than a terrace out of place. We generally do not expect to find them on very flat surfaces, although, in eertain cirenmstances, a single terrace of low elevation has a good effect. On slight declivities, two or three feet of descent will afford a suitable opportunity for introducing this species of ormament. Where there is no slope, the terrace may nevertheless be introdneed by raising the base of the house sufficiently at its first erection, and then by carrying the earth that is neessary for the embankment. Where there can be only a small breadth of dressed grounds between the house and the park, the terrace wall may form the fence of these grounds, and may be more in keeping with the house than one of a lighter construction. The most important position of the terrace is on the drawingroom front; but it is not necessarily confined to that, as it may be extended along the ends of the house, and even of the offices, if these latter touch the side of the dressed grounds. Terraces should be considered architectural formations of the grounds: as such, their leading lines should be level, whether they are bounded by walls or by banks; and these lines shonld also be parallel, and especially when there are more than one terrace on the same slope. The npper surfaces, too, 
slould be strictly parallel in their planes : any deviation in this respect gives the whole a twisted appearance, and suggests the idea of their having been executed by incompetent workmen. There are sundry points connected with terraces, such as the breadth of their platforms, their height, the number on the same declivity, their junction with the natural banks into which they may run, the angles of inclination when they are sloped, and various other matter's, respecting which no general precepts can be given that would be applicable in all cases. These must be determined by careful study on the spot, and repeated consultation of the eye. We may remark, however, that the length of a terrace is always a more important property than its breadth. A broad terrace, indeed; is always desirable, but unless it is more or less elongated, it will seem to degenerate into a broad platform. The latter form, however, when it is avowedly such, and does not pretend to the usual character of a terrace, is not an inferior arrangement, and may be inade an object of considerable interest.

Terrace WALIS.-These are retaining walls, either with a cope brought up to the level of the platform, or with a parapet or balustrade rising above the surface of the terrace. In either case, their main use being to support the mass of earth behind them, they seldom admit of much variety or ornament in their construction, except when the architecture of the house requires a decorated parapet or balustrade. A low terrace, unless in peculiar circumstances, scarcely calls for either; but when the retaining wall is high, a parapet is indispensable for the protection of per'sons walking on the platform. 'The best substitute for a parapet is 
a low, broad hedge, or a border of shrubs formed along the edge of the terrace: in some cases the border may be shaped into a sloping bank of considerable breadtl, and the height of the wall proportionally reduced. The union, in the same terrace, of the retaining wall and the sloping grass bank, seldom produces a good effect. Their most suitable combination is when the wall is made to support the lower portion of the bank; but when this plan is adopted, neither the wall nor the bank should be high. Regularly sloped grass banks, surmounted by a parapet, have a peculiarly incongrious appearance: the walls or parapets look as if they wanted a base, and the banks seem to have been piled up against the lower parts of the walls to lide deformities. As the parapets appear to rest on the edge of a sloping surface, they present the very image of instability; besides, on the top of a grass bank they are not ordinarily required for protection, nor, indeed, for any useful purpose. In short, they are altogether in bad taste.

Note. - In the severer latitudes of our northern states, terraces should be cautionsly attempted, and adopted only after mature deliberation. In loose soils, terrace slopes should lie at easy angles when grassed over, and secured with heavy walls when uprightly faced. Except in precipitous grounds, the formation of terraces' to any extent cannot be highly recommended. Flooding rains tear them, and deep frosts heare them out of place. It is evident our anthor is not passionately in love with them, even in the less frosty climate of Britain.-ED.

Grass Slopes.-Terraces are often fuced with grass slopes instead of walls; and though the resulting effect $4 *$ 
is inferior, these slopes are very suitable for places where a plain style of decoration is required, and particularly at a distance from the mansion-honse, as on the sides of bowling-greens or in flower-gardens, and in the more remote parts of the pleasure-grounds. It must be admitted that a terrace with a regularly formed grass bank of considerable depth has mostly a bad appearance. This arises partly from its surface being so plain as to have no variety, and partly from the absence of a diversity in light and shade, particularly in those slopes which face toward the south. A long, natural slope of grass is often very beautiful; but, on examination, it will be found that it is free from that dead, mechanical uniformity common in artificial works. Perhaps, however, light has the greatest influence in this respect-a fact very much overlooked in landscape-gardening. The surface of the slope is turned up toward the light; and so it wants that variety of shade which even a plain wall exhibits at different periods of the day. Accordingly it is found that, when facing the north, and in an inferior degree when facing the east and west, these grass slopes are alway's more effective than when turned to the soutb, for in this last position they are seldom seen in shade, and consequently.have a bare and bald effect. Nevertheless, a long, deep, grassy slope, closely shaven and neatly kept, is always popular, however ineffective it may be in the eye of refined taste. There are some means of relieving its monotony, which we shall indicate in the following paragraphs.-ED:

Simuds on Terrace Banks.-Long, bare slopes, and particularly when there are irregularities of surface which could be removed only with great labor and 
expense, shonld be wholly or partially corered with sliribs. When there is a considerable height of bank and breadth of slope, several effective terraces may be formed along the bank with walls, borders, and walks, and intermediate slopes planted with lanrels, constantly kept down by pruning to the lieight of two or three feet. The interest and variety of these terraces are increased by scattering over them a few ornamental trees and shrubs, which may be allowed to assume their natural form, but shonld not be introdnced in such numbers, or be permitted to grow to such a magnitude, as to injure the low shrubs. These banks of low:evergreens are more suited for sontliern slopes than grass is, as they are more permanently evergreen, and, from their greater intricacy, have more rariety of light and shade than a closely-mown surfice of grass can have.

Starrs on Terraces.-Flights of steps form an excellent means of decorating terraces. When connected with walls, they are susceptible of a considerable degree of ornament. Stairs on grrass slopes aftord less scope for decoration; vases placed on their sides may be deemed the most proper objects for this purpose. Stairs should be placed at the ends of terraces, as well as at their centers; they may be omitted in the latter position, but if they are only found there, they have a sensible effect in diminishing the appearance of length in the terraces, by dividing them into halves. Properly, stairs should be in connection with walks, but they may sometimes be introduced withont the latter. In either case, when there is more than one tier of terraces, the flights of stairs should be successively carried from the top to the bottom of the whole 
series. Any thing short of this produces an uncomfortable feeling, as if some of the flights of stairs liad been misplaced through perversity, or lost by mistake.

Note.-We can imagine various more important objects on which the same amount of money can be expended, in ormamenting parks, or pleasure-grounds, than stairs connected with terraces. That now and then such things may be necessary, and even ornamental, is probable; but wherever they-teriaces and stairs, alike-can be avoided, their omission should be no source of regret. They are expensive to make, at the first, and are perpetually getting out of place, in our frosty winters, afterward.-ED.

Upper Surfaces of Terraces.-We shall suppose that the architectural variety of terrace has been properly constructed, with a good wall in front, and a broad level above; the latter should be traversed by two spacious walks, - one near the house, and the other along the wall. The intermediate space is to be occupied with flower-beds cut out of grass, or placed in gravel, with box or stone edgings. Fountains, dials, vases, and other architectural ornaments, may be introduced with excellent effect. These may compose groups of themselves, or be made the centers of different groups of flower-beds. The character and arrangement of these objects should be in keeping with the style of the buildings around. In the case of terraces faced with grass slopes, the walks should be arranged as in the other variety. The flower-beds should be laid ont in grass-plots, or with broad verges, or with raised stone edgings round the figures cut in the grass. Sinall gravel walks, with box edgings, do not suit this 
style of terrace. Stone blocks supporting vases may be ranged along the tops of the banks, and also laurels grown in boxes, and trained to represent the orangetrees used for this purpose on the continent. The nther processes of ormament are much the same as those referred to above, only, perhaps, they should be carried out in a plainer and lighter style.

Tire Flower-Garden.-Among the most important and interesting portions of the pleasure-grounds is the flower-garden, when the place is extensive enough to afford room for its being formed into a separate department. In small residences, the whole of the flower-garden may be close to the house; but in those of considerable magnitude, it is always desirable that it should occupy a distinct section of the dressed grounds. In botl cases, care should be taken to bring it into harmony with the general scenery, of which, indeea, it should form a constituent, though a more highly and minutely-finished part. On this account, the principles which regulate the formation of the dressed grounds generally, should also be lield as applicable, with slight modifications, to the flowergarden. That garden, whether geometrical or otherwist, should be so arranged as not only to compose an effective whole, but also to exhibit such secondary and minor grouping as will produce good individual groups in its divisional sections, when these are seen in positions from whieh the whole cannot be comprehended. From want of conformity with this principle, flowergardens have sometimes a fine effect when seen from one or two leading points of view; but when examined in detail, they lose all their interest, except what arises from individual plants, or masses of flowers and shrubs. 
Effective secondary and minor grouping not only adds to the beauty of fine plants, but very much improres the appearance of those which scarcely deserve that name.

Site of tile Flower-Garden.-Convenience of access requires that the flower-garden shonld be at no great distance from the house. It may be separated from the other grounds by trees and shrubs, and if the kitchen-gardens are not remote, it may take an intermediate position between these and the house. The site should be warm, sunny and dry, and well sheltered, thongh not shaded. It shonld be remembered that the beanty of the flower-garden arises more from its graceful arrangement and superior culture, than from fine views existing without its boundary. Such views, then, are not necessary to complete it; and a seeking after them may deprive the garden of that shelter which is absolutely indispensable to the successful cultivation of fine plants. This circumstance should be kept in mind, both in the selection of the site, and in the laying ont of the component parts.

The Ground Color of the flower-garden, and of its walks, has a considerable influence on the effect of its arrangements, and, as it varies, sometimes leads to the adoption of different styles of gardening. Independently of the plants, there may be said to be only three main varieties of ground-coloring in flower-gardens, viz: the green of the grassy turf, the black or dark brown of the cultivated soil, and the tints of the gravel, varying in particular eases from bright brown to bluish gray; and the extent to which each of these colors is visible, either apart or in combination, gives a distinct expression to the whole scene. The flower- 
garden may be formed with walks, borders, and flower-plots, without any intermingling of grass turf, and, if well laid out, and kept in good order, it has, in summer and autumn, when the ground is covered with plants, a rich and raried effect; but at other seasons it has a bare and stripped appearance, and, presenting little else than the somber hue of the naked ground, exhibits scarcely aught that can interest or attract. On the other hand, a flower-garden formed on a ground-work of grass lawn, with walks and borders well arranged and attended to, has at all seasons a clothed effect; and though in winter the grass has a less lively tint, yet it still looks like a carpeted apartment with some of its more showy decorations awanting. The flower-garden without grass is, then, like a house which has not only lost its carpets, but nearly its whole furniture. Te do not wish unduly to depres ciate the one style of garden, and to exalt the other beyond its merits. In the garden composed entirely of walks, and borders, and fluwer-plots, a much greater number and variety of plants may be grown, and very beautiful scenes may be prodnced by means of these, together with flowering shrubs and evergreens. But the grass flower-garden, from the simplicity and quiet repose of its well-arranged lawns, has a much finer effect at all seasons. The color of the walks, taken in connection with their number and breadth, produces an effect, more or less marked, on the flower-garden. Dark, dingy color's, on the one hand, and bright, glaring tints, on the other, are equally to be avoided; those of a warm shade, such as light sienna-perhaps the finest of all - should be chosen, when they can be had. The reddish yellow of the Kensington gravel 
has deservedly made it a favorite. In the sunall divisional walks in the fluwer-garden, a varicty of tints nay be introduced; but violent contrasts should be avoided, and in the larger walks a more uniform color ought to be maintained, as contributing to the best general effect.

The Parterre, both ancient and modern, may be described as a geometrical flower-garden, laid out on a flat surface, and, in addition to its furniture of plants, adorned with a variety of artistical objects suited to its style and character. The most proper site for a parterre is the platform of a terrace, or some lower level, on which its whole arrangement can easily be seen at once from an adjacent elevated position. Unless it is placed on such a site, the effect of its numerous figures will be in a great measure lost, and it will appear more a piece of entangled complication, than a well-ordered and nicely-balanced geometrical design, which, from its very nature, it is intended, and therefore ought to be. The ancient parterre frequently covered a large surface. It had its divisional sections so arranged that one side or end was made the exact counterpart of the other, and all its alleys and flourishes were repeated with the utmost precision. Some of the sections were large and plain, and were intended for the reception of plants; while others were cut into an infinite variety of shapes and traceries, in which the edgings, the color of the soil and sand with which the compartments were filled, and the tints of the alleys by which they were surrounded, all went to make up the general picture. The inherent sameness of this style of gardening no doubt led to these extravagant attempts at intricacy; and the same result was 
aided by the comparative paucity of fine plants which existed when parterres were introduced. Some attempts have been recently made to revive this style in its original perfection; but when it is considered how difficult it is to adapt designs, intended for spaces of six or eight acres, to pieces of ground about oneeighth of that size, we cannot be surprised that they have miformly failed. Besides, the ancient style is entirely out of harmony with the modern taste in relation to all the other component parts of a country residence. We might as well propose to convert a modern drawing-room, with all its elegances, into a baronial hall of the fifteenth century. The modern parterre is not quite so complicated in its figures, even when cut out of turf, in which case it is most akin to that of the ancient forms. When formed of borders, with box or other edgings, it is intended to be filled with plants, and may be made a place of considerable beauty. In its geometrical forms it still requires as nice adjustment as ever; but the interest is not now made to center wholly, or in great part, in its configurations and traceries. The principal aim of such scenes should be, not the display of the artist's illdirected ingennity, but the exhibition of fine plants, which, in their present numbers and beauty, afford abundant materials for the adornment of flower-gardens. Annuals and green-house plants are chiefly required for the summer and autumn decoration of parterres; but a supply of evergreens and vernal plants shonld be kept in pots, to fill up the vacant beds in winter and spring. A due attention to these expedients will maintain in the parterre a permanently clothed appearance, and will preclude that hare and 
uninviting aspect which it would otherwise present at certain seasons.

The Rosary is one of the departments of the flower-garden, deriving its name from the beautiful flower to whose culture it is specially deroted, and, as such, possessing much interest and beauty. Of late years, it has deservedly received increased attention and faror. We wonld not, indeed, banish the roseborder, the tree or pillar roses, and the rose treillage, from the terrace or flower-garden; but we cannot help viewing a distinct and elegant "garden of roses" as not the least interesting addition that can be made to pleasure-grounds. The number and varicty of fine roses now in cultivation seem to demand a separate locality, and as there are many antumnal flowering kinds, the season of bloom may be prolonged from the middle of June to the early frosts of winter. The rosary requires a good, strong, loamy or clayey soil, over a dry subsoil, and a sunny and sheltered site. It may either occupy a section of the flower-garden, properly so called, or may find a place on some rarm lawn in the dressed grounds. In both cases, it must have an inclosure sufficient to exclude rabbits and hares; but the external treillage-work nsed for that purpose may be made to conduce to the decoration of a lawn. Internally, it is generally laid out somewhat in the geometrical parterre style, but there is no absolute necessity for these forms. It may also be composed of beds in grass, with suitable gravel walks, or of borders and walks without grass, as may be best adapted to the site, or most agreeable to the taste of the proprietor.

Note-Amid all the flowers which beautify and 
enliven the earth, in sweetness, purity, and fragrance, none can approach the rose. The most pains-taking labor's of the naturalist, and the skillfulest combinations of the botanist in hybridizing and perfecting the finest of all other flowers, lave never yet produced a rival to its simple, stainless beanty. No place can be complete without its "rosary," gracefully disposed and highly cultivated. We commend it, as one of the most grateful objects of attention, to the female inmates of the dwelling. It is scarcely necessary to remark, that the rosary should be within the immediate riew of the windows of the best and most frequented apartments of the house.-ED.

The American Garden is another special department of the flower-garden, and is consecrated to the growth of those shrubs and other flowering plants which thrive best in a peaty soil. It by no means holds good that all these plants are natives of America, thongh undoubtedly the greater part of them come from that continent. We refer to the rhododendrons, azaleas, kalmias, andromedas, etc., which, growing spontaneonsly in the temperate regions of both the old continent and the new, and being sufficiently hardy to endure the climate of Great Britain, contribute very largely to the beanty of our gardens and dressed grounds. It is desirable that they should have a separate department allotted to them; but they should not be confined to it, for they may be scattered throughout all the shrubberies in the place. When in a distinct locality, and well arranged, the American garden may be made the most permanently evergreen portion of the grounds, and therefore may not inaptly be denominated the Pleasure-ground Winter Garden. As 
such, it should contain glazed structures, in which the heaths of the Cape, the rhododendrons of India, and the azaleas of China, may find a climate and receive a culture suited to their natural habits. Many plants in the American garden do not necessarily require a moist peat soil ; they may be grown to great perfection in a healthy sand, in a sandy loam, or sandy clay, or in a regetable earth composed of the decayed leaves of trees. They do not thrive in common garden-soil. The Annerican garden may be either a section of the flower-garden, or may be formed in some detached spot on one of the lawns. If the site is naturally suited for this class of plants, some expense may be saved in the formation of a proper soil. Portions of the site may be slightly shaded with advantage, but should not, at least in the northern parts of the island, be naturally damp. The hybrid rhododendrons, which have been raised from the tree rhododendrons of India, though not quite hardy in many localities, may yet be grown very generally, if planted in warm and sheltered positions. As these rarieties bloom late in spring and early in summer, their flowers attain a greater beauty if their flower-buds are protected from the vernal frosts by some temporary awning or light glass covering. Happily, many new and hardier sorts are now introduced every year.-American gardens assume a variety of forms. They may be formed either with small intervening lawns or without them. They are generally.laid out on grass; but as the plants they contain are mostly evergreens, that groundwork is not so necessary as in the rosary and flowergarden.

Note.-The "American" garden is ours, of course, 
and we need little foreign instruetion as to the varieties of plants with whicl to embellish it. In the combination and arrangement of the various trees, shrubs, and flowers with which it is planted, the same directions will apply that govern the other garden grounds. Yet, in the soils most congenial to the field or forest shrubbery that may be introduced, their favorite localities should be consulted, and peaty, sandy, or loamy earths provided, as may be required. For detailed instruction in these, American authorities are the safest guides.-ED.

The Mixed Frower-garden is one in which the above-mentioned special departments are not kept distinct, but in which the inmates of the parterre, the rosary, the American garden, and other classes of flowers and shrubs, are all mingled together in agreeable variety. To these may be added a number of artistical decorations. It is certainly the most effective arrangement, when all seasons are taken into consideration. When laid out in a superior style, it should be made the most highly-decorated seene connected with the residence, whether its place is immediately adjacent to the mansion or is withdrawn into a more remote division of the pleasure-ground. In a work like the present, we cannot offer definite plans for this species of flower-garden; indeed, these plans may be as varied and numerons as the diversified circumstances of places or the varying tastes of different proprietors. We may remark, however, that the living occupants of the mixed flower-garden should be so arranged, that while they fill certain grouped beds with annuals, green-house plants, and roses, they should be so placed as not to detract from the general 
effect of the scene when their respective beds are empty, or when the plants are small or in a state of decay. Grass is the most suitable groundwork for gardens of this description; but some of its groups of flower-beds may be interseeted by walks bordered with edgings of box or low flowers; and this, by increasing the variety, will add to the general effect. Terraces are admissible only when consistent with the natural form of the ground. They should be connected with the eonservatories, or other plant-houses, when these structures are erected in the flower-garden, and in that case they may be faced with walls, and may receive considerable architectural decoration. Apart from such associations, they are better formed with grass slopes. Both forms afford good points for viewing the riches of Flora spread out below. Fountains, pieces of water, dials, vases, etc., may also be introduced, either grouped together, or niade the centers of figures or elusters of figures allotted to the growth of flowering plants and shrubs. Some of these means of ornament demand a separate and more detailed notice.

- Artistical Decorations.-Vases and statuary form admirable ornaments of flower-gardens, when fine in themselves and when well arranged; but the latter condition is somewhat diffleult to fulfill, and therefore requires attentive and tasteful management. Vases are more adapted to geometrical arrangements. They are peculiarly well suited for terraces, on which, however, they should harmonize with the architectural forms of surrounding objects. They may be placed either singly, or with groups of flower-beds, in the more irregular styles of designing. The employment 
of statuary in flower-gardens and dressed grounds is a much more difficult subject. It must be owned that, in this country, it has seldom a very satisfactory effect, partly from the severity of our climate, and partly from the want of those associations with antiquities and architecture which make Italy, as it were, the native home of statues. To our taste, scarcely any thing seems more uncomfortably out of place than black or white painted figures peeping forth from a group or mass of shrubs. Indeed, the less that is seen of them in such circumstances, the better; and they would be often well away altogether. Statues sliould always be in connection with architecture; on terraces they may be appropriately introduced, along with fountains, as the centers of primary or secondary groups of flower-beds. We should hesitate to distribute them singly throughout the grounds, unless the whole place has a more architectural complexion than is common in this country.

Note.-The good sense of our author, in excluding ordinary statuary from ornanental grounds, is to be commended. It certainly lias little fitness to an Ameriean elimate. Vases are appropriate when properly disposed. Earthen vases should be taken under shelter in winter, as the frosts will spoil thein; and iron ones, in imitation, protected against filling with water. All vases, indeed, should have a hole in the bottom, to pass off the water that may fall into them. They may be erorked, when required to hold water or earth for the preservation or growth of flowers or plants. Vases are both classic and picturesque ornaments to buildings and grounds, when in keeping with the architecture of the place; but they are chiefly suited 
to the different varieties of the Italian style of buildings.-ED.

Rockworks are pleasing objects, when well executed; but they should hardly be introduced, except in places where their position indicates that something of the kind is not unnatural - that the rock projects inartificially through the ground, or that it may have been laid bare by some needful excavation. The materials of rockworks should not be altogether foreign to the geology of the district; or, if they are so, their natural stratification should be imitated as well as possible, as, indeed, it ought to be in all cases; for this, if skillfully done, will take off much from their artificial appearance. It is a common, but a very great error, to construct them of all the curious, rugged, weather-eaten, or water-worn stones that can be collected from the sea-shore or the bed of a river. How such conglomerations should have ever been imagined to be like actual rocks, it is difficult to imagine. The slag of glass-houses, and the scoria of blast-furnaces, may be described to be materials quite detestable - ugly in themselves, and unpropitious to the unhappy plants which grow on them. We would not have a rockwork a sort of out-of-cloors mineralogical museum, though some variety of stones is not objectionable. One representing various geological formations is more worthy of approbation, as it may be made interesting and instructive in itself, as well as ornamental to the grounds. If expense is to be incurred, it is better that it should be laid out in this way, than that it shonld be lavished on the purchase or collection of mere curiosities. It may be added, that for the construction of a rockwork, even of 
considerable size, a great amount of stones is not necessary. Most of its interior may be of earth ; and to produce a sufficient illusion, it may be enough to stud some portions of the surface witl stones. In a few years, the growth of plants and low shrubs placed on it will conceal apparent defects.

Note.-The only "rockwork" an American should care to introdnce into lis grounds, is that which nature las placed upon them; and such, agreeably located, may be made decidedly ornamental when partially clothed with creeping vines and shrubbery. In grounds naturally rocky - that is, in ledges and masses, as distinguished from lands where the stones lie in loose flats, or boulders - a sufficient amount of rock should be retained to preserve the character of the grounds in consistency with the geological surface of the surrounding country. They are a natural feature of the place, and natural features, not unpleasing in themselves, should always be preserved as a characteristic of the locality.-ED.

Shelter of the Flower-garden.-It has already been remarked, that to the flower-garden proper shelter is indispensable. In providing this needful protection, most people plant an indiscriminate mass of trees and shrubs, without regard to individual effect or botanical classification. We humbly think that this is the part of the ground in which something like a scientific character in the disposition of the trees and shrubs is most suitable. Without carrying this to such pedantic extremes as some do, we should be inclined to arrange the trees mostly according to their genera and natural orders. Beginning at some conrenient point, as with Tilia, (lime,) the planter might 
continne with Acer, (maple and sycamore,) Esculus, (horse-chestnut,) Fraxinus, (ash,) Quercus, (oak,) Pimus, (pine,) and with various otler families. When the number of hardy species is small, several genera may be collected into one clump; but when the kinds are numerons, as in Quercus and P'inus, several groups may be formed of one fimily. The dwarf species will take their places in front of the others. For low trees or slurubs, to fill up the margin of the taller masses, we shonld employ the more showy species and varieties of Magnotia, Cytisus, Cratagus, Arbutus, Rhododendron, Azalea, and others of the numerous flowering shrubs and low trees procmable fron nurseries. Along with these should be planted a quantity of yews, hollies, and laurels, to form masses and underwood.

Note.-In most parts of the United States, limes, maples, horse-chestnuts, ashs, oaks, and pines grow too large, and create too much shade, when used for shelters to the flower-garden. Besides this, their roots extend so far as to rob the garden plants of their nutriment, which can only be prevented by a deep, open ditch between the line of trees and the garden grounds; and such a ditch is unsightly. Shrubbery of tall growth is better; which may be composed of evergreens, like the rhododendron, or the privet, which is perfectly hardy in our elimate, and other shrubs easily procured in the vicinity of almost every garden. In the arrangement of these, if shrubs of different variety and size are nsed, the taller should stand in the rear, while the smaller should take the front position, and the whole bank of protecting shmbbery rise, amphitheater-like, from the garden, that the eve may rest 
upon a continuous and unbroken line of verdure. The effect of sucl arrangement is harmonious and beautiful.-ED.

Plantixg in time Pieasure-grounds Graserally:Hitherto we have been speaking of the dressed grounds in immediate connection with the mansionhouse; but our remarks may, with some modification, be extended to the whole pleasure-gronnds. The intermixture of lawns, and of groups of shrubs and trees, must he carried thronghont. American and other flowering shrubs may be sprinkled along the edges of the lawns and openings. In some places the trees may assume the character of woods, with masses of evergreens in the way of underwoods; in other places, the lower growths should only form occasional thickenings among the taller trees. This variety of scenery may be improved and enhanced by the interest derivable from the trees themselves. Not to repeat what has been said above, about combining the natural families in the vicinity of the flower-gardenthongh it is obvious that the principles there recommended may be bronght into operation in any part of the pleasure-grounds - we may point to the striking effect produced by certain exotic trees, when near the eye of an intelligent observer. At a distance, and viewed in a line perpendicular to its direction, a mass of beeches may not seem to differ much from other deciduous trees; but the result is otherwise, when the eye is sufficiently close to the objects to discern their kinds, or when their peculiar forms stand out in strong relief. On this principle, the conspicnous, or what may be called the staring trees, should be mostly of the rarer species, and of the more uncommon forms 
Probably some of our readers may remember the use which Martin, the painter, makes of the cedar of Lebanon, in his Illustrations of Paradise Lost. In the same way attention may be directed to the tulip-tree, the weeping birch, the purple beech, the deodar cedar, the arancaria, and many others which will readily suggest themselves to amateurs in arboriculture. Of course, it is not intended that such stunted curiosities as may be necessary in botanic gardens, should be thrust forward into undeserved notice; but where rarity of occurrence, or quaintness of structure, is combined with beanty or vigor of growth, these qualities shonld always be taken advantage of. The reader will find this subject pursued at greater length in a subsequent chapter.

Walis in tile Pleascre-grounds.-Certain leading walks are required in the grounds attached to a country residence. One or more passing from the mansionhouse through the pleasure-grounds, will be found necessary. Another, proceeding from the drawingroom front, or principal terrace, may direct its course to the flower-garden, the kitchen-garden, or other objects of interest. These walks should also lead to the places from which the finest views are seen. For purposes of recreation, and the proper exhibition of the grounds, a rariety of secondary walks are needful. As a general rule, it may be noted that all narrow walks should be aroided. On all walks in pleasure-grounds, three persons, at least, should be able to walk abreast, a qualification which will require them to be at least seven feet wide. When narrower than this mark, walks produce an unsociable disjunction of a party, and mar that conversational enjoyment which is one 
of the main charms of such scenes. Short and frequent zigzags in the line of walks should be avoided, as they not only look ill, but also require a continual twisting and turning, to the utter interruption of easy and meditative walking. Walks, and especially the leading ones on terraces and in the dressed grounds, ought to be very carefully and efficiently constructed, otherwise they can not be expected to be firm, dry, and comfortable at all seasons. They should be bottomed with from four to six inches of hand-packed stones or old bricks, broken small on the top, or blinded with land gravel, small flints, or fine roadmetal, and then covered with from three to four inches of gravel. Pit gravel, as binding most readily, is the most suitable for making a firm walk; and therefore, when it is to be had in sufficient quantity and of a proper quality, it should be used in preference to other kinds. Sea and river gravel do not bind so well, from lack of earthy matter; and therefore, when employed for the first three inches, it should receive a slight admixture of earthy sand, or ashes, or rotten rock; and after this layer hias been made firm by rolling, it should receive a thin coating of the water-carried gravel. Walks should be made full, with a slight rounding in the center, amounting to from one-eighth to threeeighths of an inch to the foot of breadth; more than this makes them unpleasant to walk on. Small drains along the edges of the walks are needful, especially when the surface of the ground slopes toward them. On inclined ground they should be furnished with gratings, to pass the water into the drains, and to prevent it from furrowing the gravel. Various substances have been used to bind the surfaces of walks, and to 
give them the appearance of pavement, such as Roman cement and coal tar; the latter, when mixed with gravel, composes a hard, firm, smooth surfaee, but the resulting color is not agreeable. The favorite hue of gravel is yellow or light sienna; these liave a warmth and richness of effect which are never to be found in any dull or dark-colored variety. On the other hand, shell gravel, though clean, is too light and glaring, particularly in sunshine. The edging of walks should always be low; a deep border of grass is msightly, and seems to indicate eareless keeping. Box edgings should also be small and low. The only allowable deviation from this rule occurs in the high edgings necessary to mark the figures of a parterre.

Note.-As we have before remarked, walks are exceedingly expensive in their construction, and subsequent care, as, without nice keeping, they are anything but ornamental to the grounds. For ordinary purposes, therefore, the fewer of them, the better. Yet, let these few be what walks should be-substantial, and to the purpose. Walks, for pedestrian use, should be chiefly confined to the pleasure-grounds immediately about the dwelling. When extended into the park, they detract from its character of extent, and dignity; and if intended to be nicely kept, are frequently disturbed and profaned by the amnoyance of the eattle. Unless for a secluded path, to steal away on to some sequestered spot, the roads for driving should only occupy the park, and the "paths" need be but trodden footways, like an "Indian trail," threading its most sheltered and unfrequented parts.-ED.

The Formation of Lawns. - A fine sward of grass is of great moment, particularly in terraces, flower- 
gardens, and bowling-greens, and, as such, calls for some notice in this part of our subject. The first requisite is a good surfice soil; for where this is wanting no grood grass can be obtained to form a fine turf. It is vain to expeet a rich and perpetnal verdure on stiff elay, or on tilly and heathy soils. From eight to sixteen inches of good loam or of fine light mould, aceording to the nature of the subsoil, will generally be sufficient for this purpose. An object of nearly equal importance is a copious supply of grasses adapted to such soils. These are most readily obtained by sowing the proper seeds. It is an absurd practice to sow the difierent varieties of rye-grass, (Lolium perenne,) most of which are really annual, or at most biennial : in this way a fine peremnial turf will nerer be formed, though a natural one, more or less worthless, will probably form itself from seeds of grasses contained in the ground, which are most likely to be of the coarsest lind. Probably, after the lapse of six or eight years, a sward barely tolerable may be produced by constant mowing. Our own experience warrants us to say, that with a proper mixture of perennial grass seeds, a fine sward may be grown in two years. We may add, that eareful and frequent rolling and mowing conduce greatly to the speedy formation of a fine sward.

Note.-The best possible grasses for American lawns are Blue-grass, (I'oa compressa,) meadow or' green grass, (Poa pratensis.) and white clorer, (Trifolium repens,) which grow spontaneously orer most parts of the United States. They make a soft, thick turf, like wool, and require only to be often cut to maintain a 
constant verdure thronghout the growing season. The long and expensive array of foreign "lawn grasses" frequently advertised by the seedsmen, are of no account; and if applied will have to be renewed with the native grasses we have named, to make a permanent, smooth, and acceptable lawn.-ED. 


\title{
CHA P TER IV.
}

\author{
THE PARK.
}

Definition - The Unity of the Park- Natural Character of the Ground - Acquired Character of the Ground - Planting in the ParkSurfaces to be Planted - Arrangement of Woods in the Park-a Group - a Clump - a Mass - carrying out the Arrangement of Woods - Grouping of Plantations in the Park - Outlines of Plantations - Belts and Circles - Artificial Style - A renues.

The Park.-Under the general name of Park we include all those plantations and pasture-lands surrounding a country residence and its dressed grounds, which are in the immediate possession of the proprietor, and are managed by his servants, or at most are only let out from year to year for grazing. In the vicinity of cities or large towns, and in thickly populated districts, the park is nsually inclosed by a wall or fence of sufficient height to exclude ordinary intruders; in more remote districts its boundary-fences differ little from those common in the country, except that they may be a little higher and more carefully kept.**

\footnotetext{
- TLa park, chase, and forest are remnants of the territorial arrangements of fendal times, and are, indeed, different forms of preserres for beasts of cluse and other game. The forest, often of rast extent and of diversified surface, was the exclusive prerogative of royalty, and was invested with peculiar laws and privileges. The chase, a name still oecurring in some places in England, was a smaller portion of country, lying in a state of nature, and uninelosed. The parls was of unore linited dimensions than either of the former, and was surrounded by fences. In the conception of a park, inclosure is the dominant idea; and bence, in the Lowlands of Scotland, whicls were inclosed within the memory of the last generation, a fenceri field of any description ls, in popular usage, called a park.
} 
The park may be viewed as distinguished by the quantity and variety of its woodlands, arranged in the form of plantations, or dispersed in elumps and groups through its pasture-lands. We have already adrerted to various subjects connected with a conntry residence; to these we shall again refer only as forming part of the arrangements of the park scenery.

The Unity of the Park may be described to be that harmony of effect produced by well-arranged scenery which, however diversified and picturesque, does not suggest any discordant or offensively incongruous ideas. A park, indeed, of considerable extent, will never form one picture; and neither will a small one, unless in unfavorable circumstances. A simple or single unity, then, is a quality not to be expected, and hardly to be valued if it could be obtained. The absence of discordance, a character quite compatible with a beautiful diversity, is perhaps all the unity that is desirable. It must be confessed that this is a subject which has received very inadequate attention, both in the theory and the practice of designing. Very often, in the laying out of grounds, no general plan has been adopted, or at least no pervading idea has been carried out. Improvement has proceeded in a bit-by-bit way-by the planting of a field here and a knoll there. Clumps or single trees are set down in adjoining fields, fences are partially removed, and fragments of hedgerows or belts of plantation are left standing in places whence they ought to have been removed, or if preserved, should have been made the nuclei of clumps or groups of trees. The result of all this is confusion at the very least. In many cases, and even in places of considerable note, what beauty there is has arisen from 
the marked character of the locality, or from the accidental circumstance of an existing mass or group of fine old trees, rather than from any systematic efforts on the part of the designers. This frequently occurs where parks hare been gradually enlarged by successive additions. Very often, instead of a fine park, we find ourselves in the midst of an accumulated mass of acres, woods, fields, and fences, without any visible arrangement in reference to beauty of individual outline or to harmonious combination. The impression is that of a labyrinth. The only unity is contiguity of space. We do not say that there is no interest even in such scenes; but it arises from the beauty of single trees, or occasional nooks of greenery, or detached pieces of rock or water,--rery beantiful things, certainly, in themselres, but only a scantling of what might have been secured by the moderate exercise of taste and foresight. After all, an extensive and pervading unity is often unattainable. Some corner of a neighboring estate, some Naboth's vineyard, comes in the way, and, offending the feeling of appropriation, must be planted out if it cannot be purchased; or a parish road, or a church with graveyard and hanlet, may obtrnde themselres irremediably. In such circumstances, the absence of a visible disunity may be the most favorable consummation that can be realized.

Note.-We cannot but regret that our anthor has not enjoyed the privilege of risiting America, that his eye might for once be gratified with the sight of the grandeur and beauty of the natural park scenery so often presented to the traveler in our new states, and still remaining in some of the old ones. We know hundrecls of agricultural estates which can boast parks 
of unwonted beauty, almost unknown and unappreciated as such by their proprietors, which are devoted to the common purposes of grazing their herds. The "barrens" of the west, as they are locally termedany thing but barren, in reality, as they are among the most fertile of lands when brought into cultivation-covered with scattering trees, and groups, and clumps, and masses of forest of the largest dimensions, and in great variety, with copses of underwood scattered beneath, present the most luxuriant sites imaginable for such purposes. Occasional stretches of prairie interrene to add to their variety, and frequently a pond, or lake, or running stream adds life and spirit to the landscape. Large tracts of these have been inclosed, and with a discriminating good taste in many of their proprietors, the original trees have been preserved and now remain in their fullest growth and luxuriance. Mountains, and extended waters alone, are wanting, to give them a perfection which all the arts of artificial planting and cultivation cannot equal. Further south, and east, but still on the slope of the western waters, hills and mountains add variety to the scenery of these natural parks. More heavily timbered than the barrens, the finest forest ranges are frequently inclosed with the open lands, and dotted with herds and flocks; and scarce aware of the fact themselves, their proprietors are in the enjoyment of parks and pleasuregrounds such as few of the aristocracy of Europe can boast, in native grandemr, beauty, and fertility. On the Atlantic slope, a greater variety of surface, and of natural objects may be found, with which to combine and form a more perfect aggregation of interest, but diminished in the lesser fertility of the soil, and 
the splendor of its regetation. Few "Naboths' vineyards" here stand in the way of the appropriation of all that need satisfy the taste of one who has the means to enjoy his bent to the utmost in possession of such a pleasure. Such are our agricultural parks, and while subservient to profitable purposes in grazing, they may minister to the finest taste in all that embellishes the land with natural beauty, and grandeur. To their preservation, we commend, most earnestly, the attention of those whose enviable lot it is to possess them. For the more restricted objects of such as seek the possession of a park as an object of luxury in the populous districts of country contiguous to our large towns and cities, the natural features of open ground, and forest, in appropriate places, and sufficient variety, are not so readily found; and these must, of course, be supplied by planting and eultiration. To them are the instruetions of our author chiefly directed.-ED.

Natural Character of the Grocsd.-Most places have intrinsically a natural character, which is mainly dependent on what may be ealled the contour of surface. This, being a matter of great importanee, shonld receive immediate and studious attention, both from the proprietor and the artists who may aid him in erecting his house and laying out his grounds. It is obvious that the nature of the surface must materially affect the style and position of the mansion-house, the adornment of the dressed grounds, and the extent and character of the park, approaches, and, in short, every thing connected with a country residence. Nature affords an almost infiuite variety of contours, each requiring or snggesting a different treatment. For 
example, the house and its environs may occupy part of a dead flat, a level as uniform as a painter's canvas; and this situation may be accounted the least felicitous, or certainly the least suggestive, of all, as it obliges the designer to create rather than regulate a landscape. Again, the surface may be concave, including the two sides of a valley of moderate width; or it may be the lower part of the slope of a hilly country, where it gradually descends into the plain - in other words, one side of a broad valley. On the other hand, some surfaces are convex-a long and slightly elevated ridge, we unay suppose, or a lower spur of a mountain or range of hills, or a bold promontory running into the sea. Once more, the house may be seated on the shoulder formed by the junction of a primary and a transverse or secondary valley, on a platform orer a lake or arm of the sea, or on the winding bank of an inland stream or navigable river; and of course the character of the park and gronnds must be modified by these varying circumstances. Manifold are the other diversities of natural surface; and to the slightest reflection it must be apparent that they cannot all be dealt with in the same way. On a convex surface, for example, we do not generally meet with standing water; the beauties consist mostly of distant views, and the business of the designel is to select these, to render them conspicnous, and to set them off with beautiful foregrounds. On the other hand, the concare surface suggests water scenery, such as the lake or the artificial river. From such a locality the distant views are necessarily limited, or extend only in the direction of the valley; but if the house be planted near one of the rising edges, or on the breast of a slope, there will 
be room for admirable pictorial effect in the middle distance and opposite ridge, as well as for delicious walks or rides in the lower grounds. We throw out these hints rather as illustrative of contour than as indicating specific plans for particnlar localities. We need scarcely add, that this natural diversity of surface, while in its indiridual forms it affords one of the essential elements of beauty, and has probably suggested moșt of what is really fine in the practice of the art, utterly precludes the laying down of any general rule as everywhere applicable. We shall have occusion to revert to this principle; meanwhile, we beg the attention of our readers to its importance.

Acquired Character of the Ground.-Except where a residence has to be formed in an unimproved and desolate region, (and that is a task not of common occurrence,) the locality to be dealt with will have not only a natural, but also an acquired character. Some growing timber is generally found where a man thinks of setting down a house, and there are fences, roads, and perhaps farm bnildings or other rural objects already existing. And if the designer is called in, not to give a primary plan, but to improve or extend what has been already done, he is sure to find before him buildings, plantations, and other matters connected with country residences. All these circumstances originate what we have called an acquired character, which, in some cases, may have obliterated in a great measure the natural expression of the place, particularly if the latter was not strongly marked at first, or it may have brought out snch a want of harmony as to necessitate improrement. In dealing with the acquired character of the place, the artist will find that 
there are certain objects, such as the mansion-house, offices, and portions of the roods, which can seldom be altered, and which must be treated as fixtures. Such objects are not unfrequently sources of great embarrassment. They often so modify the whole of the alterations that the place, even after every possible improvement, is greatly inferior to what it might have been had the fixtures been skillfully arranged at first. All these points, then - the natural contour and expression, the acquired character, and the mutual modifications produced by the intermingling of both - must be carefully studied by the artist; for it is only by means of a matured knowledge of these, and by availing himself of the alterations which they place within his reach, that he hopes to bring out those beauties which the eye of taste can discover slumbering and buried, as it were, in a mass of deformity and confusion. No quickness of eye can dispense with, hardly any inspiration of genius can supply the want of, careful and accurate study on the ground.

Planting in the Park.-Planting is the principal means of ornamenting the park; and accordingly, trees and shrubs are the chief materials with which the designer has to operate. On the presence or absence of these, and on their due arrangement and distribution, will depend the superiority which the lands of the park, thus adorned, will have over lands of a similar character and extent, but occupied simply as pastures. This difference may be small at first, but it will be rapidly developed by the yearly growth of the trees. In this department of planting, varions objects are to be kept in view. Shelter may be necessary in particular quarters; seclusion, also, is requisite. But the principal 
aim which the ornamental planter has to keep in view is, of course, scenic beauty. To attain this end, particular attention must be given to the nature of the surfaces which are to be planted; and of those we shall now proceed to speak.

Note.-In order to a perfect understanding of his future plans, the proprietor of a park on which im: prorements of any kind are to be made, should have a correct topographical map of the whole territory embraced, that at his leisure he may become familiar with every point of interest, and with every elevation and depression which it embraces; and if the geological formations of his grounds differ one from another, such differences, and their character, shonld also be noted, to govern him in their fitness for the growth of certain trees, shrubbery, and plants, in preference to others. All such should have their appropriate place, as on their adaptation to the soil will their growth and ultimate effect materially depend.-En.

Surfaces to be Pranted.-Of these we may remark generally that their exact nature should be carefully ascertained, their present and possible future physiognomy should be attentively studied, and the amount and distribution of the planting should be determined accordingly. The planter will endeavor to bring out the beanty which intrinsically belongs to the peculiar situation, or may be elicited from it. At the same time, he will take care not to shut ont whatever is picturesque in the surrounding country from the principal points of view. We have already said that a flat surface is the least propitious to pictorial effect; still, by skillful management, a certain amount of it may be accomplished, or, at least, a great improrement may 
be made on a bald and uninteresting locality. On such ground the artist will have to depend on his own power of grouping together the masses of wood which he may deem necessary for the purposes of decoration; and though he cannot avail limself of any swell of the ground to add variety to the scene, he will have the satisfaction of knowing that the ontlines of his plantations, clumps, etc., are perfectly at his command, and that their effect camnot be diminished by any twist or contortion of surface - a difficulty of not unfrequent occurrence in other cases. Deprived of any advantage which may be derived from undulations calculated to lieighten the effeet of a plantation, or to relieve the defects of an ontline, he will have to create a piece of scenery which should be complete in itself, and shonld form a gracefnl and harmonious whole. The disposition of the woods should be such as to make up a rariety of apparently connected, yet diversified, scenes, of considerable lengtl and breadth within the park. It is of great practical moment to remark, that to accomplish this, less planting will be required on a flat than on any other surface. The open spaces should be roomy, the glades wide and sunny, and the whole expression of the place should, so far as is possible, be light and airy. In an undulating or hilly country, the worls onght rather to occupy the sides of the hills or rising grounds than the interrening ralleys or hollows. In this way the woods are seen to greater adrantage, and they teud to increase the height of the eminences on which they are placed, and proportionally to deepen the grounds below them. When the ralleys or de- pressions of a park are all planted up, as they too often are, the necessary result is the concealment of 
the natural inequalities of the ground, and the production of a dull uniformity. Of course, while recommending the planting of wood on the higher positions, we do not mean that the smooth outline of every green hill should be exchanged for a serrated one of trees placed over it. Still less would we recommend the capping of all the knolls with clumps of wood, which is in as bad taste as planting up all the hollows. We would have some of the hills or rising grounds in the park covered with masses of wood feathered out toward the bottom, with scattered groups thinly distributed across the valleys. In other cases, the rising grounds might be clotlied with groups becoming thinner toward the top, and thickening as they descend on both sides. Where there are low green hills with fine outlines, the summits of one or more of these should by all means be left vacant, and a curtain of wood diawn along the lower slopes and base, and even the adjacent valley. Where there is no such variety of surface as we have supposed above, or where the park is of limited extent, each case will fall to be dealt with as the natural character of the place will suggest or allow, regard being had to the general import of the principles already indicated. The planting of the sloping banks of the platforms which constitute the main area of some parks, and of the ravines by which they are intersected, has often a wretched effect. This is owing to sereral causes; for example, to their being formed without relation to other groups or masses in the park, and to their trees appearing above the banks, and dividing the land-with what seems a meager, ill-grown belt. When such places are planted, they should form a portion of some of the more general combinations in the 
park, and the spaces covered with trees should be extended beyond the top of the banks in order to secure a certain amount of breadth. It sometimes happens, that in such planted ravines the lines of light along the upper edges of the slupes, as seen from below, proclaim the poverty of the whole affair. We add an earnest caution against the inconsiderate filling-up of ravines and hollows by means of wood. Such places may have no agricultural, and but little pastoral value, and yet the choking of them up with plantations inay be almost the last thing which an improver ought to do.

Arraxgement of Woods in the Park.-This is a subject second in importance to none which we have hitherto treated. Success in this department is essential to that unity and harmony which are necessary to the derelopment and finished expression of park scenery. It is, however, a matter somewhat difficult to handle, both in theory and in practice. For the sake of clearness, we may begin our remarks with the explanation of a few terms which we can not help using, and which, indeed, we have used already. A Group is a term borrowed from the technical language of painter's and sculptor's. It denotes an aggregation of at least two, but generally more objects, closely related to each other by nearness and position, but only remotely related, in these respects, to other objects. In the internal structure of the group, the objects are so arranged, that while one or more may occupy leading positions, the others hold only inferior places; at the same time, each must appear to belong to the same combination, and to contribute to the making up of a whole. The external and remote relation of the group to other objects, is of a more evanescent and indefinablo 
description, but is of not inferior importance. A group may, indeed, be conceived in a state of isolation firom objects of the same kind, as two or three human figures in the corner of a landscape-painting, a few statues on a terrace, or a patch of palm-trees in a wide desert; but there is probably always, even in the case of the palm-trees, a mental reference to existing accompaniments, perceived or imagined. In landscapegardening, a group, though apparently detached, is uniformly part of a whole. It remains to be added, that groups are either simple or composite: simple, when they are made up of single objects, such as trees or statues; composite, when they are formed of single groups, or of the other more condensed and extended bodies of trees, which we now proceed to mention. A Clump is a group considerably increased in the number and density of its component parts, without any apparent internal arrangement, but with a definite figure and decided outline. A clump of trees may be called a small wood. Viewed at a moderate distance, the form of that half of it which is next the spectator can be taken in at once by the eye." A Mass of wood is hardly a technical term, but yet a rery convenient one. It denotes a large body of growing timber, exhibiting an apparent continuity of boughs and foliage, and of such depth that the horizontal light can not be seen through the stems of the trees. That portion of

* Lexicographers inform us that the word clump was originally written plump, and they adduce as examples, a plump of trees, of horss, of fools, etc. Near the beginuing of 'Marmion,' Sir Walter Scott, imitating an old ballad, employs the expression, " $\mathrm{a}$ plump of spears," and adds in a note, "This word properly applies to a flight of water-fowl, but is applied by analogy to a body of horse." From certain analogies in words derived from the Anglo-Saxon, it would seem that clump and lump are nearly allied, if not identical; and it must be owned that a lump of trees is a phrase uot a little descriptive of many clumps to be found in parks and pleasure-grounds. 
an extensive plantation or forest which is visible at once, may be called a mass of wood. In the park, however, the masses, generally speaking, are of more limited dimensions; yet they are so large, that while the irregularities of outline in the vicinity of the spectator can be perceired by him, the forms of the ex: tremities are distinguishable only when viewed from a considerable distance. Masses and clumps may be either inclosed or open; they are generally inclosed. It will be obvious from our definition of a composite group, that the places of the component members may be taken by other groups, and by clumps, and even masses; so that we might speak of a group of groups, a group of clumps, and a group of masses. It will tend to clearness, however, if we reserve the term group, at least when accompanied with qualification, to denote the smaller and simpler aggregations. In the larger and more composite arrangements, we shall prefer the expressions, a system, or combination of clumps or masses. As the word grouping has been extensively used to express the principles of combination or composition in rural scenery, we shall continue to avail ourselves of it when necessary. It is hoped that, the above explanations being kept in mind, the following remarks will be sufficiently intelligible. In carrying out the arrangement of the woods, the designer should begin with forming certain leading systems of masses, to be filled up and completed by secondary and minor combinations, together with the necessary clumps or groups of scattered trees. For the principal masses, a few leading positions should be selected. The house and pleasure-grounds should be included in one; a hill, or rising ground, or rounded 
eminenee, may form the center of a second or third; while the boundary of the park toward the home farm, or other portion of the boundary where disagreeable objects are to be concealed, may afford room for a fourth or fifth. The secondary combinations, though inferior in extent to the primary ones, will yet, in many parks, be of sufficient dimensions to vail the stables and farm-offices, and to shelter the kitchen-gardens when these are placed in detached positions: they may also be employed with good effect in other places, such as around the entrance-gates and lodges, the gamekeepers' and park-keepers' cottages, and along the boundary of the park. The secondary masses are also serviceable in connecting the principal ones, and so making up what we have called the systems or main combinations. The minor combinations are frequently required for the same or similar purposes, especially when they are formed of groups of trees. The size, number, and variety of these diversified aggregations of trees, necessary for the decoration of the park, will, of conrse, depend very much on the extent of the ground and the natural character of the surface. When it is intended to give the whole what is called a park-like appearance, spaces of grass land of considerable length and breadth should be left open between the principal masses of plantation, and also between a number of the secondary ones. On the other hand, when it is desired to impart to the place the character of woodland scenery, the main combinations should be enlarged and drawn more closely togrether, and the grass lands shonld be redneed to the form of glades and openings in the woods. In localities with a level surface, where little is seen beyond 
the park, and where the creation of as large an amount of scenery as is possible within it is an essential element in its formation, the combinations of masses of plantation will necessarily be fewer, and placed further apart, than where the surface operated on is of an undulating, hilly character. Where a large body of wood is required, it is injudicious to form the leading and secondary masses into dense and almost impervious thickets, as is too frequently done; it is better to arrange them into a gradation of masses interspersed with lawns, glades, and other openings, in addition to the rides by which they may be traversed, and the ordinary roads necessary for their management. Where the main masses are small, a similar eflect may be produced by lesser openings and indentations. In both cases, groups of trees, and single trees, should be scattered through the glades and along the margins of the larger bodies of wood. This is exemplified in those places in which masses of wood are seen forming pleasure-grounds round the mansion-house. We do not mean that these masses of rood in the park should be dissected into as many and as small divisions as are often necessary in the dressed grounds; but there are many places in which the roods are greatly enlivened by such open spaces, and by the addition of a few clumps and groups of single trees, relieving yet attached to the general masses. In hilly and mountainous countries, large masses of wood are sometimes planted, but it is seldom desirable to intersect these with wide openings or lengthened glades. A better effect is produced by bays and indentations, as already recommended. When the woods have been formed, as abore explained, into a variety of leading 
and secondary combinations, the position of the individual plantations should be such as obvionsly to appear portions of their own systems. They should rary in size as well as in form, and should be separated by open spaces of varying breadth. The projections of one may advance toward the recesses of another. In many cases they may be blended into one whole by means of groups of trees scattered round and among them; these will produce a light and varied effect, and tend to counteract any formality in the general ontlines.

Grocping ur Combination of Plantations in the PARk.-In our previons remarks, we have taken for granted that some general arrangement of the different bodies of wood should be adopted. It is necessary to insist on this principle, for it is rery frequently overlooked or neglected. TTe often see isolated masses occupying positions for which no apparent reason can be discovered, and which probably were selected from the original low value of the ground in an agricultural point of view. Trees, the remains of old hedge-rows, or of departed clumps, or of woods that have been removed, are dotted over extensive surfaces. Fences. dividing the park into separate fields, draw their meager and ungraceful lines, perhaps, through the rery center of a fine breadth of vier. The effects of such misarrangements are confusion, incongruity, or at least a sad diminution of the pleasure which the other fe: tures of the scene might have afforded. To alvit? these unfurtunate results, some general system of grouping should be sedulonsly followed. In extensive parks of from one to two thousand acres, there is often room for three or four, or even more, main combinations, such as rre have specified in a previous article. 
In more limited locilities, the prineipal grouped masses will, of course, be fewer in number, or on a reduced scale. When these have been marked ont, the subordinate masses, clumps and groups, are to be laid down in proper coürdination. Single trees should be scattered irrergularly here and there, in such a manner as to hamonize with the larger masses, and to take off the stiff and constrained alpearance presented by the ontlines of the denser plantations. By this mode of grouping, the grass land; will be thrown into masses of greatel breadth, and the surrounding woods and groups of trees will exhibit entire scenes of themselves, connected yet dissimilar, united yet dirersified, by the ever-varying interchange of glade and wood, of broad grassy expanse and clump and group, or single trees, and exhibiting at one time the deep shade and dense color of the mass, and at another the lighter and airier graces of individual forms. When a park is laid out on these principles, that is, with a properly arranged gradation of combined masses and groups, and a bird'seye view of it is taken, it will present a highly-diversified appearance; and thongh there are few surfaces on which the whole system of grouping can be made visible at once, yet from so much of it as can be seen, the successive pictures will be more numerous and more pleasing than can be afforded by any chancemedley system. The increase of variety and intricacy in form and position, will invariably produce, in a corl'esponding degree, a diversity in the succession and intensity of light and shade. In short, we have the certain superiority of design, if that design is not obtrusirely formal and artificial, over the imperfect, irregular, occasionally interesting, but rarely occurring 
beanties of accident. The principle of grouping, in parks and pleasure-grounds, though of the utmost importance, bas, we believe, been sadly neglected, both in the original formation and in the improvement of country residences. Many planters seem to have no conception of the principle. Others seem to have been disposed to cover with trees all surfaces which they could not turn to any other account. Some have been seized with the itch of transplantation; they have not known when to stop, and have clung with invincible pertinacity to the misdeeds which they have accomplished with much expense and labor. Some, again, have been unwilling to cut down old trees - a reluctance with which we cordially sympathize - and have failed to connect them skillfully with the adjacent masses, which either have been or might have been formed. The only consolation in these cases is, that the labyrinthine effect formerly alluded to not unfrequently cloaks the deform:ties, if at the same time it obstructs and precludes the beauties which might have existed. We see little of the confusion, because the dense encumbrances of the landscape do not permit us to see much of any thing. The eye of taste, indeed, can often discern the loss, and suggests regrets that so many natural advantages have been thrown away. There is, however, one specific fault to which the neglect of general grouping very commonly leads, and which ought not to be passed over without some animadversion - we mean what has been ludicrously but appropriately called the Dotting System. This consists in placing a number of objects in nearly equidistant positions, without reference to their intrinsic or relative importance. Examples of this mode of planting occur 
in the park when plantations, clumps, or groups, are set down in complcte isclation, or withont any perceptible relation to snrrounding objects. Trees are seen occupying the broad spaces or narrower openings between the woods, withont a greater affinity to one mass than to another. This effect, exhibited on the side of a green hill, where it is peculiarly infelicitous, has been well compared to a pattern of sprigged muslin. Into pleasure-grounds and gardens the dotting system has also intruded: in these, figures containing shrubs and flowers. as well as single shrubs and trees, are often sprinkled with the most undeviating regularity. The main object would seem to be to leave unoccupied no piece of grass or plat of ground above a certain and very moderate size. On the lawns of many gardens this paltry and tasteless system has been carried ont to the greatest perfection. A better taste, indeed, is now being diffused; we have, however, observed a finished specimen of this style in a garden of great pretension and celebrity, and which is supposed to exhibit the very perfection of British gardening. A pinetum is dotted over an extensive lawn, without respect to the natural physiognomy of the trees, and, what is more surprising, without any regard, so far as we could discover, to their botanical affinities as species. A few formal clumps of rhododendrons lend their aid to complete the general insipidity. It must be admitted, at the same time, that it is seldom that lawns are dotted with such hardy tenants. They are frequently filled with half-hardy objects, undergoing the miseries of acclimatizing experiments; $*$ and the

*All efforts in the way of accommodating the plants of warmer regions to our somewhat ungenial clime, ought to be encouraged and promoted, as erery additiona. 
eye is regaled with the stunted growth and discolored foliage in summer, and the stake, and the nat or furze eorering in winter. The results of the dotting system are, a general monotony, and an insipidity, which no variety in the character of the trees or shrubs will ever overeome. There is the same breadth of light and shade on this tree and on that - the same patehwork of sunbeam and shadow wherever the eye can turn. On the common, or in the native forest, we do not find the wild denizens of nature put down at equal distances. Where the hand of man has not interfered, the trees and bushes are seen in masses and irregular clusters, with single plants seattered round them, and forming groups of greater or less dimensions. In the mass or group yon will seareely find half a dozen plants growing at the same distance from each other. The single trees are mostly in closer proximity to some portion of the ceneral group than to another. Hence arise the infinitely-diversified beanties of the native pine forest, and the eaptivating and almost inimitable grace of the wild oaks and birches on the sides of the Highland glens: and hence, too, the eeaseless interchange of light and shade, both on tree and turf, on which the eye nerer fails to dwell with pleasure. In short, grouping is everywhere productire of interest and beanty; dotting, of insipid monotony and languor.

Outlines of Piantations in the Park. - In forming plantations, it is necessary that the outlines of those portions of them which require inclosure should

bardy tree or shrub is so much clear gain to gardening. But the transition or training processes slould be kept in their proper place, viz: the inclosed garden. Where besuty of scenery is the object aimed at, the trees and shruls should be sufficiently hardy for the average climate of the locality. Those slightly tender, or requiring shelter from cutting wads, may find some warm, quiet nooks in the Hower-garden or pleasurc-grounds. 
be adjusted with reference both to the general grouping and to the surfaces on which they stand. Of course, these outlines should assume a pleasing variety of form. Large, curring sweeps seem to be favorite lines, and they are occasionally fine; but they become insipid when often reprodneed. On the other liand, the firetwork of numerons small recesses and projections are equally wearisome; besides, when seen in front of their general lines, their zigzaggeries are scarcely discernible; and, indeed, the less the better. Instead of these, let the projections be hold and the recesses deep, rather abrupt than otherwise, yet without the appearance either of too much angularity or of roundness. The outlines of plantations and clumps in parks have very frequently the expression of constrained formality, and that, we believe, from two distinct eauses. The first is the inferior eharacter of the ontlines themselves; and the second is the practice of planting the trees either close up to the fences or in a line parallel with them. In some places, where it may be difficult to have the fences so formed as to produce, by the projections and reeesses of the plantations, that degree of light and shade which is desirable, a general line of fence must be formed, as well as circumstances. will allow, with a forward and retiring bend where a projection and a recess are wanted, the effect of the latter being brought out by the planting. This is a useful method to adopt with elumps. In these, a general line of fence, curving round the promontories, if we may so call them, and bending toward, but not entering deeply into, the bays, will be free from those angularities which it is impossible to aroid when the fence follows servilely the feathery ontline of the trees. 
At the first planting, the proper recesses should be left entirely vacant within the fence. Unless this is done, one or other of two results is necessiry, - either an extremely irregular ontline of fence, which from its crooked continuity is offensive, or, if this is aroided, the very great probability that the wood will nercr be properly thinned and grouped out at an after period. This remark holds specially true of clumps planted for the subsequent formation of groups. Many things which "the prophetic eye of taste" designs, are forgotten in the routine of the present, and the mind grows familiar and satisfied with what was rever intended to be permanent. Perliaps, at length, in the estimation of the forester, the well-kept fence becomes of more importance than the clump itself, and all the attention the latter receires is a little thinning at times. For these reasons, we eurnestly recommend that the feathered outline of the plantation should be carefully formed at once, even though considerable vacant spaces should be left within the fence. Of course this recommendation is not intended to apply to all cases; but there are many places in which its adoption is the only method of securing a varied ontline of trees, with a pleasing outline of fence; and there are other places in which a considerable improvement may be effected by its partial use.

Belts, Circles, etc.-Belts should never be introduced into the interior of the park; in their straight outlines and heary uniformity there is a total want of variety and intricacy of effect. On the extreme boundary, something like a belt may be at times indispensable. On those farm lands where shelter, not beauty, is desired, the belt, provided it is of sufficiont 
breadth, is one of the most useful forms of plantation. Circles and ovals should be entirely confined to the flower-beds of the dressed grounds, among which, when small, their effect is good enougli. In the park, they are disinguished by their invariable tufty character, betraying clearly their formal and monotonons outline. Of all forms of plantation, they are annong the most intractable with which the improrer has to deal. If the rood could be spared, their entire removal would be the speediest and most advisable improvement to which they could be subjected; but as this can seldom be done, the improver must exert his ingenuity in grouping them out, or in making such additions to their mass as their size, position, and the nature of the ground will allow.

Note.-After the full and exceedingly practical remarks of onr author, on the several heads of park improrement, scarcely a word need be added. Yet, as the formation of American parks, different from English ones, as frequently consists in cutting out, thinning, and clearing away the forest, or parts of it, as otherwise, a remark or two may be applicable to that branch of the subject.

In remarking on the naked appearance of our country, in its most extensively cultirated districts, nothing is more common than the expression of regret and disapprobation at the sweeping manner in which the original forests have been cut away by the carly settlers, and that so few, or scarcely any trees are left to shade and embellish the land. Such expressions are usually made withont a proper knowledge of the subject, and which a hetter acquaintance with the character of omr original forests would correct. It is not 
aenied that a recklessness in cutting away and sweeping off every restige of the forcst, in some cases where it might be beneficially lett, is too often the case; but when we reflect that the main object is to bring the forest lands under immediate cultivation, and that such cultiration can not succeed under shade, and among a mass of living roots, lying mostly near the surface, such as original forest trees usually present, it need be no cause of surprise that the pioneer, looking only to his bread, and the future support of his family, should clear his lands of every impediment to so desirable an end. In point of utility, he is entirely right. For cultivation alove, in its most profitable result, a field should never hare a tree nor a shrub within it. Pastures, only, require them; and it is a subject of discussion still, with grazier's and stock fariners, whether shade trees are at all beneficial to the growth and thrift of cattle - the subject of taste, or embellishment to the land, by the presence of trees, being excluded. Our forests are composed of trees thickly set, and drawn up to great heights, with bare stems, small, slender tops, and roots widely spreading ncar the surface of the ground. A continual struggle for supremacy has existed with them, ever since they grew at all, and each tree striving with all its might to overtop its neighbor, and shoot up into the light and sun, which are indispensable to their cxistence. A part of the forest being cut away, and sun, and air, and their drying influences admitted, many of the border trees of the standing forest sieken and die from the absence of their usual moisture; others are prostrated by the violence of the winds which now break in upon them through the clearings; and even 
if left standing in masses, years of time are necessary to acclimate the exposed trees, and quicken them into a renewed and healthy growth. What, then, must be the condition of a single tree, or a dozen, or fifty trees, even if left contiguons to each other, deprived of their mutual support, the shade of the underwood beneath them, and their accustomed moisture at the root, with the glaring heat of the sun drying up their trunks, and the driving winds lieaving at their tops like a lnge lever acting on their thin-spread roots, spread over a surface of soft, porous monld? They must be blown down, or die a lingering and miserable death, of necessity, in nine cases out of ten, at least, where the experiment is tried. Occasionally a tree, more firmly rooted in the soil than usual, may survive. But what, in case it do survire, is such a tree good for? Its hinge, bare trunk, shooting up into the sky, and supporting a meager tuft of half-feathered branclies, is any thing but an object of beauty; it scarce ever grows another inch, and remains only as a specimen of what the forest among which it stood once may have been. It is measurably so with smaller trees, few of which, under like circumstances, survive at all; or if they do, scarcely ever arrive at a full and vigorous maturity. We speak feelingly, and from long experience. The acres of forest which have been cleared under our immediate supervision, may be connted almost by the thousand; and among the multitnde of trees which we caused to be left, in various kinds, and under all circumstances, not one in a hundred remain; and were we now to make a choice, at the end of twenty years, to produce the best effect in a forest plantation, whether to go into an old, dense wood, and clear portions of it 
out, or cut it all down, and clear it away, and take the chances of the young growth immediatcly springing up to supply its place, we should assuredly take the latter. In such case, howerer, we should not apply fire to the clearing; the brush should be simply theww together, and if the timber and wood were not arailable to be drawn away, they should be lefit on the ground, to decay and licep it moist. 'The young wood will immediately spriar up anew, and grow with a rapidity which would reclothe it in a surprisingly brief space of time; and this, thinned by degrees, could be trained and fashioned into the finest models of forest grace and beauty.

There are positions, however, where limited tracts of wood exist, and of second growth on light, dry soils, where it may be safe to enter, and by a gradual thinning and clearing out, letting in by degrees the sum and air, the remaining trees may be preserved without injury to their growth. Such woods should be thus treated ; but under the circumstances before described, the felling and clearing off of the entire forest is the better course; and where they are required, young trees had better be set ont anew, than to trust the contingences of preserving the original trees, which will be almost sure to end in disappointment.-Es.

Artificial Style.-In our remarks on parks and pleasure-grounds, we have hithcrto kept in view almost exclusively the natural style in these departments of gardening. We would not, however, altogether overlook that artificial style once so much in vogue, but which, though now antiquated, is worthy of preservation where fine specimens of it exist, and which might eren be reproduced, at least in part, in certain cases. It is 
a poor and pedantic taste which can derive pleasure only from one kind of beanty. The main features of this style, in the park, are avenues and alleys, the latter being sometimes parallel, sometimes crossing each other obliquely, or radiating from a common eenter; and in the pleasure-grounds, in addition to these, the principal eharacteristics are terraces, stairs, fumtains, and statues. Portions of these means of olnament have been adopted with good effect in many well-laidont places. We should be disposed to recommend them, as indeed we have, in connection with the mansion-house and flower-garden. When the strueture of the ground is favorable, they form a suitable transition from the highly artificial forms of architecture, to the free, unconstrained developments of natural objects. In the park, angular and radiating alleys are perhaps tolerable only in level situations, or when they can be viewed from a moderately elevated platform occupied by the mansion-house.

Avenues.-We seldom recommend the planting of avenues in the park, except in certain localities noticed in our remarks on the approach. The stiff formality of the avenue is injurious to park scenery, as it frequently divides, by its straight lines, a fine expanse of grass, and obscures the most interesting part of the lindscape. Another objestion to the avenue is, that it requires to grow for the lifetime of two or three generations, before it produces its full cfiect; and it is not surprising, therefore, that it is so seldom planted. The same trees, arranged in groups and clumps, would present a beantiful appearance in one-third of the time.

Arenues should hardly ever be attempted, except 
on a level surface, or on ground with a slight and uni. form rise. A close avenue, composed of two rows of trees, and planted on an undulating surface, has al. ways a poor look; on the contrary, even in such situitions, where there are breadth and mass, as in the compound avenues at Windsor, the effeet is fine.

The question may be asked, "What is to be done with an old established arenue?" We may answer, partly in the words of Mr. Gilpin. "The avenne," says he, "is in general so destitute of composition, by cutting the landscape in half, that the introduction of it must depend upon the circumstances of the place itself. On the other hand, where time has invested it with dignity, and the rest of the scenery is coeval with it, temerity rathèr than judgment would dictate its destruetion. Breaking it by partial removal is, I think, equally injudicious." With the opinions here expressed we heartily concur. We venerate an old avenue, with its double or quadruple rows of ancestral trees. No sacrilegious axe ought to be lifted up against them, even though they divide the landscape in two. The destruction of a magnificent range of limes, or elms, or chestnuts, liallowed by immemorial associations, is too great a sacrifice to any prevailing taste, however excellent; and if by breaking is meant the removal of the greater part of the trees, and the preservation of such a small residne as will mark the position of the old lines, the effect would be rorse than a total removal.

In the dressed grounds, avenues, without injury to the general effeet, may sometimes be formed through some of the large masses of wood; but in these eases the trees should not be placed at greater distances than 
is sufficient for a broad walk or ordinary drive. We do not admire a practice which has become common of late, - that, viz., of planting some of the finest lawns of pleasure-grounds with arenues of the Indian cedar. (Pinus Deodara.) Judging from the character of this tree, as well as from the peculiar forms of the fir tribe, we have great doubts whether these cedars will ever produce a fine arenue except as a broad and open one, with double rows on each side. The Indian cedar itself is highly interesting and beautiful; so far as we yet know it, it seems admirably adapted for light grouping or single trees, and it is to be hoped that it will prove sufficiently hardy, not only to live in our climate, but also to attain that magnitude and form, which have so often awakened the admiration of travelers in the East.

Note.-In relation to "artificial style," and "avenues," we happily have so few places of such character that they are of rare impediment to those who wish to form either parks or pleasure-grounds anew. Possessing such, however, a fine old mansion, and stately trees, in whatever form they may stand, are objects of decided respectability, and may be preserved and cherished without violence to a very considerable degree of beanty and effect, in their way. The hand of "improvement," in our fast age, may well spare the relics of a bygone century, which could boast, we fear, a sturdier virtue, and a higher patriotism than prevails among their more money-loving sticcessors.-ED. 


\section{CHAPTER V.}

ORNAMENTAL CHARACTERS OT TREES, DETACHED AND IN COMETSATION.

Introductory Remarks.

Sect. I. The Forms of Single Trees-lyoad Round-headed TreesThe Spiry, Conical, or Pyramidal Configuration - The Upright or Oblongated - The Weeping or Pendulous.

SECT. II. The Colors of Trees - Table of the Colors of Foliage of Trees - General liemarks.

Srcr. III. The Ornamental Character of Trees in Combination - Conical or Pyranidal Trees - Round-headed Trees - Intermingling of the different Forms and Colors - Concluding Remarks.

If we may assimilate landscape-gardening to landscape-painting, we wonld say that trees are the principal means of ornament available to the garden artist. They are, as it were, the colors with which he paints, and with, which he fills up the ontlines presented by nature or selected by his own taste. We have already touched generally on the massing and grouping of trees - that is, so far as regards the forms and positions of these groups and masses, and their relative combinations. Something remains to be said respecting the ornamental character or expression, if we may so call it, of trees, and of the facilities which they consequently afford in the laying ont or improvement of park and garden scenery. 
The comparative value of trees, as means of ornament, is a subject which has been little studied; or, at least, it has been imperfectly expounded in books; and yet it is onc of very great importance. The expression of the ground outline of a wood or clump, for example, may be perfect in itself, but it may be modified into very different degrees of excellence by the character of the trees of which it is composed. We can conceive two parks as nearly as possible the same in other respects, still, if each is planted with trees of a distinct and peculiar lind, the difference of effects resulting will be so great as very much to diminish any original resemblance between them. Firs, when planted by themselves, or where they prevail to the general exclusion of deciduous trees, give a permanent evergreen character to the park. When the plantations are occupied by the common run of trees that shed their leares, without a due admixture of the fir tribe, the results will be masses of foliage during the summer and autumn months, and ain obrious bareness and meagerness in winter and spriug, particularly where the bodies of wood are small, or are deficient in breadth. It is evident that much mist be gained by a skillful distribution and mixture of both classes. The same remarks apply, and perhaps with increased force, to groups of single trees, and to detached trees; these are very much dependent for their beauty and general effect on the kind of the trees employed.

Our present object is rather to bring the ornamental character of trees before the notice of our readers, than to attempt a full exposition of a subject which, in a general point of view, is somewhat indefinite; and which, in its particular aspects, branches out into a 
multitude of details. Our remarks may be directed, first, to trees individually in respect to form; then, to their color; and lastly, to their expression in eombined masses and groups.

\section{Sect. I.-The Forms of Single Trees.}

The forms assumed by the individuals of any species of tree, snch as the oak or Scoteh fir, vary much with the soil, situation, and age of the partienlar tree, yet amid all their diversities they preserve a character at once discernible by the practiced eye. The oaks in the rich and open park, in the crowded forest, and in the mountain ravine differ greatly from each other, but they are plainly oaks, and have each a beanty of their own. How dissimilar, also, the plume-like ash in its youth, rushing up in some sheltered valley, to the round-headed ash of middle age, in an open situation, and still more to the gnarled, large-timbered, wavy-boughed, and pendulons-branehed ash, bending under the weight of years. In the same species, too, there are often constitutional differences, amounting almost to what botanists call varieties. These circumstances neeessarily preelude minute verbal description. Still there are certain general forms affected by trees in their natural growth, and all that is required for the purpose of the planter is to keep these steadily in view. Though every species and variety of tree has its own peculiar expression, if not distiuct character, we do not deem it necessary to advert to each separately, believing it to be sufficient for the illustration of our subject, to class them under four leading divisions, and 
then to refer to a few of the kinds principally employed in ornamental scenery. As we go on, we may point out their most suitable and effective positions in the park and pleasure-grounds.

The first division consists of trees with broad, round heads; the second, of those with a spiry, conical, or pyramidal configuration; the third, of those with upright or oblongated forms; and the fourth, of those with weeping or pendulous branches. The reader is reminded that these forms are given merely as approximations: he is not to attach to them the precision of geometrical figures.

(1.) Broad, Round-headed Trees.-Of the deciduous kinds, the sycamore, the American plane, the common oak, the Turkey oak, the small-leaved and Scotch elms, the ash, the tulip-tree, walnut, horse-chestnut, Spanish chestnut, beech, birch, hornbean, and others. The evergreens of this division are few, viz: evergreen oak, Luccomb oak, yew, cedar of Lebanon, cedar of Monnt Atlas, deodar or Indian cedar, and Lambert's Cypress. (Cupressus macrocarpa.)

The Sycamore is a large, rounded tree, fully branched and of massive foliage. Its formal outline, and its close, broad attire of leaves, are well suited to produce depth of shade. It has also the property of retaining its form in exposed situations, and in such positions it imparts to a clump or group a more decided outline than can be given by any other hard-wood tree.

The $A s h$ lias a light foliage, and a graceful, airy appearance, particularly when the branches assume a pendent habit. It generally displays much of the internal arrangement of its boughs, which is often picturesque in old age. It would be a fine lawn tree did 
it not continue so short a time in leaf. It grows well in exposed situations.

The common Oak is a magnificent tree when well grown, either in the wood or on the lawn. On the latter it acquires a broad, spreading figmre. It is also a noble forest tree, and it should be planted wherever the soil and climate are suitable. Its robust habit, its rectangular, contorted, and often horizontal branches, and peculiar foliage, afford a more diversified expression than, perhaps, is to be found in any other hardy tree. Hence the absence of monotony observable in great oak forests.

The Scotch or Wych Elm is a fine, broad, spreading tree, approaching to the characteristics of the oak. The English Elm has smaller leares, but denser branchlets, and is a square-headed tree, often ascending to a great height in a columnar form. The Beech, in sheltered places, where it has ample room, forms a large, stately tree, of a full, graceful, feathery appearance. In exposed localities it yields to the prevailing winds, and becomes meager and one-sided. When planted in a mass, it is deficient in that repose which marks some of the kinds already mentioned. The Lime is peculiarly a park and lawn tree. Standing detached, in a sheltered situation, it has a fine, stately presence, particularly when its lower branches droop; and it forms a noble arenue, whether open or close. The Spanish Chestnut is almost as fine as the oak, and exhibits a broad green foliage, and a varying expression with the advance of the season. The HorseChestnut has also a large foliage, and in early summer throws out abundant spikes of showy flowers. Its head is rather too uniform, yet when placed on the 
outside of a plantation, or the lower edge of a bank, it is often highly ornamental. The forms of the black Italian and American poplars are of a rather inferior description; but some nember's of the family have good qualities in the way of color, and from their rapidity of growth are often extremely useful.

Of broad-headed evergreens, the $Y e w$ is one of the finest of our native trees. It is of a spreading habit and low stature, seldom attaining to a considerable size on a lawn till it is of great age. Many of the yews in our pleasure-grounds are probably the remains of hedges, or trees that have escaped the shear's of the topiary artist, these having been his principal material in old times. It must be admitted that the yew is less valuable for its form than for its color. The same remark applies to the Ilex or Evergreen Oak, which, howerer, is of some importance for its foreign air, being the best representative of the olive which we have in this country. "In the warmer parts of England and Ireland," says Loudon, (and we may add in Scotland,) " the ilex forms a bushy evergreen tree, exceeding the middle size. The general appearance of the species, even when well grown, is that of an immense bush. It should be planted in the more ornamental woods of the park, as well as in the dressed grounds; and it forms an interesting variety in the shrubbery."

The Ceclar of Lebanon is at once a very celebrated and a very admirable tree. Its great breadth, its ascending trunk, or, more frequently, numerous trunklike limbs, and its tabulated, horizontally-spreading secondary branches, all contribute to give it a very unusual and striking configuration. It harmonizes finely with the level, architectural lines of the mansion 
house and terraces, and seems to repeat them in aërial perspective. It contrasts well with all other sorts of trees; it also makes up striking groups in the park and dressed grounds. We regard it as a matter of regret that, in many districts of the country, the cedar has been so sparingly planted.

Not inferior to the preceding, perhaps we might even say superior, is the Deodar or Indian Cedar, a native of the Himalaya mountains, and unquestionably the most important addition made of late years to our collections of hardy trees. As it flourishes in its natire clime, it is thus described by Dr. Hoffmeister: "It is the most beautiful of the fir tribe that exists in any part of the world. It shoots up with a tall, straight, taper stem, often a hundred feet in height, and not unfrequently forty feet in circumference. The branches grow in stages, at regular intervals, and spread out like overshadowing roofs." As it is apparently hardy, it is to be hoped that its growth may not be arrested "in mid career" by some peculiarity of our climate, as has been the case with the hemlock spruce, and some other firs. In its youthful state, in which alone it is yet known to us, its reclining leading shoot crecting itsclf continually in its second year's growth, its drooping, tress-like branchlets, and its light green color, combine to make it a peculiarly graceful object. It may be strongly recommended for both the park and the pleasure-grounds. In the latter, it should be planted where it has room to develop its natural character. In the park, it should be put down in groups of some half-dozen trees. We hare already adverted to its use in avenues. As it is at present a fashionable tree, it is introduced into all sorts of little flower-gardens 
and miniature lawns, where, if it. thrives, as we desire it may, it will speedily overshadow every thing else. We would strongly urge the extensive but considerate planting of this fine tree.

(2.) The second general form of trees is a varied one, and may be lield as embracing tbree subordinate figures: the rounded cone of the Scotch fir, and some others of its class, and generally of the holly; the truncated cone of the silver fir; and the spiry, elongated cone of the varipus spruces, larches, Swiss Cembran pine, and perhaps the deciduous cypress. Many of the pines lately introduced, such as $P$. excelsa, Lambertiana, Sabiniana, macrocarpa, are certainly pyramidal, and will fall under one or other of these subdivisions when aged. Indeed, the whole class of conifers assume their final form only when far adranced in growth.

The Holly is almost the only broad-leaved tree of this group. It is generally of a low, bushy form, rounded, but sometimes also with a spiry cone. Growing in woods, and on a light soil, we have seen it sixty feet in height, and with a trunk eight feet in circumference. It may be planted in the dressed grounds, and also in the woods of the park, as milerwood, among deciduous trees. When scattered along the outskirts of a recess or glade, it has a fine effect in thickening the mass and deepening the shade.

The Scotch Fir has been planted to a much greater extent than any other fir, in Great Britain and Ire. land. No tree has been more decried and condenmed as being ugly; and certainly, in many cases this dispraise has been deserved; a close, ill-thinned, and worse-pruned plantation of this tree, on a flat and 
undrained surface, presents, both externally and internally, a heavy, mean, uninviting appearance. But part of the blame sliould fall on the want of judgment often evinced in the first planting, and on the neglect with which it is as often followed. In suitable sitna. tions, and with proper treatment, it attains a beanty not inferior to that of any other inhabitant of the forest. The Highland variety is superior to the common one, both in the quality of the timber and in its outward appearance; it lias a smoother bark, and, throwing out its branches more nearly at right angles to the stem, it assumes a more cylindrical and less tufted form.

The Pinaster is of a medium size and conical form, with massive dark-green foliage. It is of rapid growth, thriving best on sandy, or light loamy soils, and is well adapted to the vicinity of the sea. The Weymouth Pine, in this country, is of medium size, and, unless when planted pretty closely, is apt to become a busly tree. With its light-green foliage, it has a more lively effect in a mass than most others of the fir tribe. $P$. excels $a$ is allied to the latter. It has a tapering form, long, light, silvery leaves, loose and pendent branches, and a smooth, whitish bark. It attains to a great size on the IIimalaya mountains, and promises to be equally fine in this country. In this section, our limits will permit us to mention further only $P$. Laricio, or Corsican Pine, a large, conical tree, with dark foliage, sand of rapid growth. Of its varieties, the black Austrian pine is decidedly the best; it is a large, bardy tree, with a broad, conical head, and, as it grows quickly, it promises to supersede the Scotch fir 
where early shelter is wanted. It is very liable to be injured by hares, when young.

The Silver Fir is one of the noblest of our hardy firs; rather tender when young, but growing rapidly afterward; and when old, it forms a truncated cone of great height, and is stately, massive, and ornamental, both on the lawn and in the park. P. Douglasii is a Californian species of great size. We have known it, in this country, add ten fect to its height in three seasons. Its foliage is of a lighter hue than that of the preceding, yielding therefore a less massive effect; but it forms a handsome lawn tree. $P$. nobilis is a magnificent tree in its native forests, on the Columbia river. It has proved itself quite hardy, in cold districts of this country, and is a most desirable tree for orramental purposes. The Hemloct: Spruce is a handsome, low tree, approaching to the yew in character, but is of a paler green, and, on account of its dwarfish stature, is used principally in the shrubbery.

The Common Spmice Fir is very extensirely planted, and suits a great variety of soils, though it prefers a moist, loamy one. Where it has room and shelter, it grows into a tall, stately, tapering cune. When young and densely planted, it affords a close and effective shelter, and it even forms a good hedge, in upland districts. It has a livelier effect in masses than the Scotch fir. P. Menziesii, or Menzies' Spruce, is a very handsome pyramidal tree, with a vivid light-green foliage, which, with the silvery lines on the under side of the leaves, imparts to it a gay and graceful character. It is well adapted for groups and masses in woods and pleasure-grounds.

$P$. Morinda, the Himalayan spruce, is a large tree 
on its native mountains, and in this country it grows freely in a shaded situation and a loamy soil. On light, sandy soils, and when exposed to the sun, its leares are fiequently browned by the spring frosts. It has the general form of the common spruce, but is strongly distinguished from it by its glaucous foliage, longer and narrower leares, and its more slender and pensile branchlets. It is a graceful lawn tree, and it is also well adapted to the woods of the park. It was introduced into this country in 1815, by Dr. Govan, of Cupar, who presented seeds of it to the late General the Earl of Hopetomn, grandfather of the present noble Earl. One of the original seedling plants, growing on a lawn in the gardens at Hopetoun House, is now thirty-seven feet high, forming a fine tree, feathered from the ground upward. This spruce, as well as many others of the fir tribe, may be grafted with success.* It is somewhat remarkable, that the Himalayan spruce has been found to stand the smoky atmosphere of London, better perhaps than any other fir.

The Larch is now a very common, but also a very valuable tree, for the purposes both of utility and ornament. It has the spiry pyramidal form of its class, which, perhaps, is too slight in its proportions, when young; but it acquires a grace and dignity in its broad and vigorous old age. Its main peculiarity, in relation to its class, is that it sheds its leaves, and its decorative properties reside less in its form than in its beautiful tints, which vary through a wide range, with the revolving seasons.

- At Hopetoun, in the autumn of 1827 , the writer of this work grafted sereral of the Morinda on the common spruce, at about four feet from the ground; they are now twenty-six feet in height, and apparently as vigorous as if os their own roots. 
(3.) Upright or Oblongated Trees.-Of these ire may enumerate the Lombardy poplar, the upright oak, (Quercus fastigiata stricta,) the upright cypress, (Cupressus sempervirens,) Irish yew, arbor vitæ, red cedar, and Swedish juniper. The last five are suitable only for the dressed grounds.

Trees or slirubs of this form can not be anywhere extensively planted by the improver. Their peculiar use is to group and contrast with the broad, flowing outlines of other trees, or with the architectural objects in their vicinity. The Lombardy Poplar is well suited for park scenery and for lawns, and may be put in combination with such trees as the sycamore, wych elm, and horse-chestnut, three or four of the former being made to group with six or eight of the latter. This poplar may also be introdnced with good effect on the edges of broad glates or recesses of a wood. It strould be placed so as to appear to shoot up through the branches of the broader trees, and sometimes to stand between others; and such positions we would generally prefer. A single tree, lowerer, or two or three closely gromped, may oecasionally be stationed on the edge of a larger group. The Upright Cypress, where the elimate permits its free growth, contrasts well with the cedar of Lebanon. The Irish Yew, Swedish Juniper, and similar shrubs, group well with the large foliage and broad forms of the Portugal and common laurel, and as such are valnable on the lawns and flower-gardeus. The Irish yew may be planted with good effect on terraces with grass banks; and in that case it should be trained with one stem, to prevent its assuming that loose, broad, besom-like head, which, if this 
precantion is not taken, it generally acquires, from the action of the winds and the weight of snow.

(4.) Pendulous Trees and Shrubs.-Of these we may name the weeping birch, the weeping willow, the fine-leaved weeping ash, (Fraxinus lentiscifolia pendula,) and the new funereal Cypress from China. The weeping ash, elm, beech, lime, and the American weeping willow can scarcely be called trees, as their height depends on that of the trees on which they are grafted. They are, consequently, more curious than useful in the way of ornament.

Most of these plants, being of no great height, are better suited for the dressed grounds than for the woods of the park; their introduction, however, into both of these places is the source of considerable interest and variety. Their proper place is not in the thicket, but on the lawns and on the outsides of the woods. Their graceful forms also render them suitable for decorating the entrance to the villa or cottage orné.

Of this class, the finest is the Weeping Birch. Its upright stem and main boughs, the thread-like drapery of its branches, and its small foliage, give it a peculiarly graceful and airy appearance. It groups well with both the broad and the pyramidal trees, larmonizing well with the former, and contrasting finely with the latter.

It preserves its character in woods, and is seen perhaps to greater advantage on sylvan banks, and on the lower slopes of hills. The Weeping Willow is, unfortunately, too tender to be of much use in the colder parts of Great Britain. In other respects, it is admirably suited for giving effect to the scenery of the dressed grounds. In warm, sheltered places, and in 
the genial climate of the sonth, it attains to the size of a medium tree, and combines singularly well with laurels, which, in small groups, are very beautiful when orertopped by a fine weeping willow. Its most effective position is in connection with water, overhanging, like a green vail, a stream or lake. The Fine-leaved $\Lambda$ sh is an elegant tree, of a broad shape, with small foliage and pendulous branches. The Common Weeping Ash is fit only for forming an arbor; as a tree, it is devoid of all grace. There is a variety in Wellhall, in Lanarkshire, which is much finer, being intermediate between the weeping and the common ash.

The Chinese Teeping Cypress is an erergreen weeping tree, one of the recent importations from China, and if we may judge from the description given by $\mathrm{Mr}$. Fortune, who introduced it-for we have seen it only in a young state - it is one of the finest of its class. In his interesting work on "The Tea Distriets of India and China," he says, "It is a noble, fir-like tree, about sixty feet in height, having a stem straight as a Norfolk Island pine, (Araucaria excelsa,) and pendulons branches like the weeping willow. The branches grow at first horizontally with the main stem, then describe a graceful curve upward, and drooping again at the points. From these main branches, others, long and slender, hang down toward the ground, and give the whole tree a weeping and graceful form." This tree appears to be hardy, and if it maintains that character, it will be an interesting addition to the scenery of the park and pleasureground, and should be planted wherever its form is admissible. Arenues composed of it would have a 
charming effect; and these arenues, as the tree is only of medium size, would not require to be of such dimensions as those planted with English elm, or lime, or deodar.

It remains to be noted, that the forms of trees vary in some measure with the season. Their internal configuration is most conspicuons in winter, when the leafless branches disclose the inner carpentry of boughs, and too often, indeed, reveal deformities. Summer, with its vail of foliage, shades much of the peculiar structure of trees. Toward the end of June, luxuriant sycanores sometimes suggest the idea of masses of green rapor reposing in the atmosphere; an appearance very different, certainly, from the numerous crossing limbs, and forked branches, and brush-like twigs presented by the winter habit of the tree. This contrast is one of the sources of the successional beauties of the seasons.

Note-In comparing the foregoing catalogue of trees, given by our anthor, the American will be struck with the meager variety which Great Britain affords for ornamental purposes, in comparison with the numbers of surpassingly noble and beautiful specimens which flourish in almost cvery different locality of our own country. It is unuecessary to enlarge on a subject so well treated, in general, by our author, further than to remark that, in tree-planting, such rarieties as, on examination, are found most congenial to the soil which is to receive them, should be selected; and where exotic trees and shrubs are introduced, they should be of hardy kinds, graceful shape, and easy growth. It is difficult to find specimens, in any part, of the world, flourishing in like climates, which excel 
our own native trees in grandeur, grace, and beauty. Our oaks, elms, maples, hickorys, all of many varieties; the black-walnut, butternut, chestnut, whitewood or tulip; the poplars, birches, beeches, ashs, larch, and several other deciduous trees, of the Northerm and Middle states; together with their erergreen pines, hemlocks, spruces, and firs - all trees of the first rank in size, and some of them of great heightwill compare advantageously with the best trees of Europe, and far excel the most remarkable British specimens of native production; and where we possess within our own forests such a wealth of trees, in all that constitutes true ornament, as well as utility, it is scarcely worth while to rack our brains, or exhaust our purses, to go abroad for others. Our Southern states produce many of the trees we have named; to which may be added, the live-oak, cypress, magnolia, and others - all appropriate for park-planting, in their own favorite regions.

Of shrub trees, large and small, almost any desired number may be found in the immediate vicinity of any park-ground in the country. Many of them are of exceeding beauty, and of all required character and variety. It is unnecessary that they be here enumerated. The ready observation of the inquirer will at once supply his demands; or, that being at fault, the volumes of Michanx, and of Nuttal, will suggest more than his most liberal wants can require.

One indispensable element of success, in the cultivation of both tree and shrub, must be observed by all planters; and that is, a congeniality of soil and climate to the tree or shrub in question. Many trees and shrubs will flourish alike in different soils - the 
stiffest clay, or the moat friable loam; others pertinaeionsly eling to a particular soil, and refuse to flourish in any other. Some refinse to grow in any but grounds light, dry, and open in texture; others love the heavy, moist, and clammy earths contignons to water. All these qualifications inust be regarded, to insure success in diversified plantations.

In "pleasure-grounds," exotic trees, of character" congenial with the soil and elimate, may be sparingly introdueed; as, the horse-chestnut, the weeping willow, and a few others, as indicating ehoicer cultivation than what is given to the "park." In the latter may be occasionally thrown the Lombardy-poplar - a tree often treated with idle abuse because it has some faults; but no one can say, and say it truthfully, that. the spire-like top of a Lombardy-poplar, peering up through the formal ontline of a group of round-headed trees, does not give both a graceful and picturesque expression to the landscape, which would be wanting without it. The lareh may partially supply its presence, but not with entire effect. Excessive use of the poplar, in some instances, has brought it into, perliaps, in that feature of it, well-deserved condemnation; but sparingly and considerately applied, it may become one of the most effeetive fcatures in park-expression.-ED.

\section{Sect. II.-The Colors of Trees.}

The tints of color exhibited in trees are, perhaps, as numerous as their forms. To advert, at present, only to the foliage, - the normal color of the leaves is green, 
but how diversified are its shades! In the deciduons class of trees, these shades range from the silvery gray . of the IInntingdon willow and white poplar through the light-gyreen of the larch and line, the full green of the sycanore and oak, to the dull, dilnte green of the alder. And in the evergreen species, the shades pass from the silvery or glaneous tints of the $\Lambda$ thas and Himalayan cedar's to the dark-green of the holly and yew, and the almost black-green of the aged Scotch fir. Here, then, are abundance of colors for the landscape-artist - colors requiring from him most attentive consideration, and on the skillful and harmonious entployment of which the suceess of his work will, in a measure, depend. We have seleeted the names of a number of trees and shrubs usually employed for decorative purposes, and arranged them under the different shades of green respeetively exhibited by them. Our readers will understand that we have designedly omitted the abnormal tints, snch as oecur in the purple beech and in the variegated hollies and sycanores; and that, in some of those given, the shades named are only approximations. On some poor, clayey and wet soils, common and Portugal laurels have a lightyellowish tint. In the shade, the hemloek spruee and common yew preserve a dark-green; in exposed situations, they are sometimes of a brownish green. 
TABLE OF COLORS IN THE FOLIAGE OF TREES.

DARK GREEN.

Portugal Laurel.

Yew, commou and Irish.

Holly.

Sweet Bay.

Phillyrea.

Luccolube Oak.

Alder.

Upright Cypress.

Oak, common.

Oak, scarlet.

Spanish Chestnut.

Horse Chestnut.

Hornbeam.
Araucaria imbricata.

Araucaria excelsa

Cedar of Lebanon.

Taxodium sempervirens.

Scotch Fir, and most Pines.

Silver Firs.

Spruce Firs.

GREEN.

Sycamore.

Norway Maple.

Beech.

Hemlock Spruce.

- Laurustinus.

LIVELY GRERX.

Arbutus.

Abies Menziesii.

Deciduous Cypress.

Lambert's Cypress.

Alaternus.

Common Laurel.

LIGNT GREEN.

Lime.

Gean.

Eln.

Bird-cherry.

Ash.

Laburnum.

Oriental Plane.

Tulip-tree.

Occidental Plane.

Black Italian Poplar.

Birch.

Lombardy Poplar.

Hawthorn.

Balsam and Ontario Poplars

Rhododendron, sorts.

\section{PROWNISH GREEN.}

Red Cedar.

Hemlock Spruce.

Arbor vitse.

Box.

Evergreen Oak. 
SILVERT GREEN.

White and Grey Poplars.

Willows, several.

Turkey Oak.

Buckthorn.
Cedar of Mlount Atlas.

Deodar.

Pinus excelsa.

Pinus Webbiana.

Toward the end of spring, and in the beginning of summer, all the greens are extremely vivid; but even then some of the species, such as the larch and balsam poplar, are peculiarly light. In June, the young shoots and leaves display little variety. In July and August, each tree and shrub shades off into its own particular green. Later in autumn, the evergreens acquire their winter tints. In October, or earlier, previous to the fall of the leaf, the ordinary hues of the deciduous tribes give place to an extraordinary diversity of colors. For example, the larch, oak, and elm take various shades of yellow, or yellowish-brown. The scarlet oak, beech, and wild cherry grow red. The ash and sycamore sadden into a grayish teagreen. If, in planting the park and pleasure-grounds, all rarieties of color are to be taken into accomt, the tints of the ripening leaf onglit not to be forgotten, as we fear they too often are. It shonld be remembered, that the ripening and fall of the leaf sometimes occupy five or six weeks of a season, which, if chastened with sadness, is to some minds a period of intense enjoyment. TVe may add, that oaks, particularly in copse-woods, and in the early stages of growth elsewhere, often retain their leaves during most of the winter. These supplementary tints of the departing year afford means of ornament not altogether unworthy of attention.

The flowers of certain trees also yield effective, 
though transient, elements of color. Some of our readers may lave come unexpectedly on a fine laburnum or thorn, in blossom, partially concealed in a secluded wood, or overhanging the bend of a remote stream, and may have received from it an impression which has not yet passed away. We need scarcely point ont the rich effects produced, at times, by the snowy flowers of the wild cherry and sloe, by the creamy bloom of the hawtborn and bird-cherry, and the more varying pink and white of the wild-apple and the horse-chestnut. Then, there is the delicate pale-yellow of the flowers of the lime and Spanishchestnut, later in the season. Among the underwoods, we have the brilliant yellow of the elegant mahonias, in spring; and in June, the lavish purple of the Pontic rhododendron, one of the hardiest and best of all shrubs for making close and tangled thickets in woods. We do not mean that the chromatic efiects of a flowergarden should be, by artificial means, elaborated in a park or forest; but there is no want of brilliant tints, even in the wildness of nature, as the common furze and broom amply testify; and the moderate and unobtrusive employment of the brighter hues of blossom, in the external grounds, is sure to please.

Even the leatless branches of slurubs and trees afford an arailable element of color. We might point out the dog-wood, with its crinson twigs, and the azerole thorn, with its silvery branches; these, incleed, belong chiefly to shrubbery or pleasure-ground. But the larch, with its light-brown spray; the birch, with its dark twigs and snowy stems; and the oak itselt, with its rarieties of russet, green, gray, and brown, are exanples of daily occurrence in the woods. The 
believe that these hues in decidnons trees, both intrinsically and as contrasted with the brighter evergreens, are a great, though often unnoticed, source of pleasure in the woodlands of winter. They help to make up that full harmony which the great instrumentalist, Light, calls forth from the living organs on which it plays.

The use of the colors of trees and shrubs, to the improver, is very great; but his application of them must depend very much on his own skill in adapting his materials to the character of the place and the nature of the ground with which he is dealing. We may remark, however, that the deptli of a recess or glade, in the woods or dressed grounds, formed for the purpose of creating a shadowy effect, is much increased by planting trees and shrubs of a full green or darkgreen color, at the point where the effect is desired. The somber color of the trees themselves, and the density of the foliage, contribute to render the shadow more intense, while an opposite result would be educed by a lighter color of foliage. Some prominent points may be brought out by a dark, others by a light or silvery-green. The effect of distance, too, may be produced or increased by employing dark-greens in the toreground, and shading off with lighter color's in the more remote objects. It is hardly needful to add, that good taste enjoins a sparing use of strongly-marked or glaring colors. White poplar's and purple beeches, for example, are admirably adapted for occasional breaks, in the way of contrast, or for completing a gradation of shades; but in certain sitnations, they would be intolerable as clumps or masses. 
Secr. III.-The Ornameatal Character of Trees in Combination.

The massing of plantations obscures to the eye the peculiar forms of the trees which compose them, and indeed, modifies the actual forms to a great extent. It is only when standing detached, or in thin groups, or at most on the margins of plantations, that trees fully develop their natural characters. In the depth of a forest or thick wood, they are usually so crowded together, and so drawn up toward the light, that their forms have little resemblance to the figures produced by their free and unimpeded growth. Still, there is a distinct character in each; for a mass of oaks has not, in any circumstances, the sime aspect as one of beeches or elins; neither does a dense, dark plantation of Scotch firs present the spiry and serrated outlines of a wood of larch and spruce. There is, therefore, still abundant cliaracter remaining, even in combined and crowded trees, to allow scope for design, and to afford materials for scenic beauty, to one who has sufficient skill to seize and employ it. In this part of our subject, we shall content ourselves with adverting to what we have called the round-headed and the pyramidal trees; the other two classes are so sparingly used, and planted so much for the production of those particular effects which we have already noticed, that we need not recur to them.

Rudnd-rieaded Trees.-Of these we may remark, generally, that they are to be employed when continuity of outline, in the clump and plantation, is the 
object aimed at. They mass more densely together than any other trees, except, perhaps, the Scotch fir; which, however, in combination, partakes very much of their character. In parks with flat or undulating surfaces, the trees planted in forming the woods should be principally of this class. Their broad outlines and massive proportions are more in harmony with the natural contour of the ground than those of a pyramidal shape. Seen from without, they have often, at certain seasons, a peculiarly silky and slightly tufted expression, which is extremely beantiful. Their internal appearance, too, (that is, their character as groves, ) when they have been sufficiently cleared ont to afford large, roomy arcades of shade, is finer on such ground than that of the more upright trees. Of course, when we thus recommend the broad round-headed trees for snch sitnations, we do not mean that they are to be planted to the exclusion of all others; a sprinkling of the other kinds will have a beneficial effect, in the way of contrasting with the predominating forms, and of adding variety to the scenery.

Conical or Prramidal Trees.-With the exception of the larch and the deciduous cypress, these are nearly all evergreen trees. This, in one respect, is an advantage; it enables them to give a permanently clothed and verdant aspect to scenery. On the other liand, when planted in large masses, on flat surfaces, and especially when they have been ill-thinned-out, they have a very somber and monotonous effect, exhibiting a large array of bare trunks below; and above, a dark, gloomy canopy of boughs and branches, excluding, perhaps, every ray of sunshine. The small, wiry forms, and almost nniversal rigidity of their foliage, 
have also a saddening inflnence, as they seldom wave except when agitated by a gale, and there is a total absence of that agrecable movement produced by a light wind playing airily among the larger leaves of the decidnons species. Besides, the pyramidal trees unite at what may be called the shoulders of the tree; and so, above that line, which is often pretty well defined, they leare a multitude of little cones or' pyramids, which, when seen in profile, have a serrated outline, and exert a monotonous and, at the same time, irritating influence on the eye. For our part, we know rothing more wearisome than those long, dark, stunted, middle-aged plantations of Scotch fir, or of mingled larch and sprnce, which are sometimes to be met in flat, clayey, agrieultural districts. Snch masses of wood, in ornamental grounds, would be hideous.

The native homes of the fir tribe are cliefly among the hills. There they not only grow more luxuriantly, but their forms adapt themselves better to the natural lines of the gromd. On the slopes of a hilly and nountainons comtry, fir-woods have a more varied and cheerful appearance, and they are seen less in profile; or, if they are so seen, it is against the higher gronnds, while the more elevated ridges form the sky-line of the landscape. In such cases the serrated outlines are not so harsh as they are on level grounds. When planted in passes, or on other steep surfaces, the trees are seen to great adrantage, towering up one above ancther, and exhibiting a greater variety of lights and shades than on more level ground, particularly when pervaded by the rays of the winter or vernal sun. Even in the lower conntry the fir tribe sneceed weil in ravines and on shelving banks, where the soil is light and the 
natural drainage effective. Occasionally, beautiful Scotch firs, spruces and larches may be seen in favorable situations a little above the level of the sea.

Many species of firs require to be planted thickly at first, in order to prevent them from forming bushy trees when young, and for the purpose of throwing the main growth of the tree into the leading stem; but in ornamental plantations they should be thinned out at an earlier period, and afterward to a greater extent, than is necessary in woods grown simply for the sake of timber. They will thus have room to develop themselves into their natural forms, instead of being drawn up int bare poles with small tufted heads. On level or slightly-inclined surfaces, frequent openings or glades should be formed through them, in order to relieve the heavy effect which they would otherwise have.

Intermingling of the Different Forms and Colors.-In the actual practice of planting, the various . kinds of trees are generally mingled together; and though this is often done with little taste, and on no fixed principles, it shows that in the common apprehensions of men, the beauty of woodland scenery consists very much in the contrast and combination of its diversified materials. It will readily be perceived that no precise general rules can be laid down on this subject. Much must be left to the taste of the proprietor and designer. Some particular effects, however, may be mentioned as attainable by the use of certain trees. For example, a mass of laurels and hollies in the pleasure-ground may be improved both in dignity and expression by having a few of the finer species of firs introduced into its center. And in the park, a plantation of decidnons trees may have its sky-line elevated 
at certain points by groups of black Italian poplar, a tree which, in ordinary ground, speedily take the lead of all others, and keeps it for many yeurs.

Ought masses of trees to be planted wholly of one species, or with an admixture of many? The question has been answered differently, both in thenry and in practice. "A forest of all mamer of trees," says Mr. Ruskin, "is poor, if not disagreenble in effect; a mass of one species of tree is sublime." $*$ We are not sure that this aphorism is not put too unconditionally, even in regard to a forest; certainly we should be inclined to dispute its validity as applied to pleasure-grounds and parks. Let the reader imagine a pleasure-ground exclusively filled with hollies, or a park adorned with Scotch firs alone. We are assured that the first feeling of the spectator would as likely be that of wonder as of sublimity, that the second would be one of oppressive monotony, and the third of absolute weariness. Of course this remark does not apply to clumps and subordinate nasses, which may occasionally be planted of one species of tree. We make this admission, however, with some reserve; for, while in the park and pleasure-ground our aim should be that unity which consists in a harmony of diversities, we must gnard against that bald and msuggestive unity which degenerates into uniformity. Homogeneons masses of trees, it must be remembered, are destitute of that pleasing variety of color of which there are traces even in spring and summer, and which, as we have seen, comes out with such manifold beauty

\footnotetext{
- We have not the slightest respect for Mr. Ruskin's authority on this question. We better coincide with his architectural taste than his arboricultural accomplishlเnents.-F.p.
} 
in the autumnal tints. We hold that evergreens, even in winter, are lightened and set off by the contrast of the decidnous trees with which they are intermingled, and in summer the harmonizing effects of the mixture are even nore striking. We are disposed to think that in the park and pleasure-ground the fir tribe should never be planted alone and in separate clumps. We wonld hardly allow them to amount to more than a third of the whole trees, in the plantation, thickening them in some places, and blending and shading them off with the deciduous speeies in others. This is also a good method of planting firs when the surfaces of large masses of wood are to be seen at a distance. We beg the reaker, howerer, to remark that we have been speaking of the ornamental grounds, not of the outfield woods or mountain forests.

In regard to the question, Ought masses of trees to be planted with one species only, or with an admixture of many? it is important to determine whether the masses in question are to be considered as viewed from withont or from within. If they are to be contemplated from withont, we hold that there should be always some admixture of kinds, to obviate that dull uniformity to which we have above alluded. It they are to be viewed from within, it cannot be doubted that a grove of unmingled oaks and beeches, or elms, especially if the trees have attained the dignity of age, has a much finer and more imposing effect than a promiscuous gathering of all manner of trees. Even the surface of the ground and its smoother sward aequire, in such circumstances, a more attractive, because a more harmonizing aspect. Planters are too apt to confine their regards to the external appearance of 
their work; they ought to remember that the plantations they are forming will, in the comrse of years, become tall woods, and perhaps groves, resorted to for sechusion and shade. This should be especially kept in mind toward the central points of their masses; and with this view they may surromd these central points chiefly with one kind of tree. In extensive grounds, a dozen or more of these central groves might be formed prospectively, embracing all the principal deciduons, and some of the finer evergreen trees; while the outer margins of the masses and clumps, and all the parts rendered by their position conspicnous to the eye, might be dressed out in that gay variety which is essential to the beauty of a country residence as a whole. Thus the predominance of one tree will give a decided character to a mass, and the intermingled subordinates which may be gradually reduced in number, if desired, will relicve it of monotony and insipidity.

In relation to the subject of this chapter generally, we hare in conclusion to remark, that no part of landscape-gardening is more neglected and misunderstood than the skillful management of trees, in the way of bringing out their ornamental value in respect to form and color. Some artists of great name hare declined this affair altogether, and, with necessarily very general directions, or even withont any instructions at all, have delegated the work of distributing the trees to the forester or day-laborer. And proprietors are too ready to ask the designer to stake out the groups and clumps, and then to leare the planting to persons who probably have not the slightest conception of the effect desired to be produced. After a few years, perhaps, 
the artist goes back to survey his work, and finds that his ground outlines have been carefully preserved, but probably discovers also that the gray poplar, with its airy form and silvery foliage, has been substituted for the robust and grave-tinted oak; or that the spiry, light-green, deciduous larch has taken the place intended for the rounded cone and dark-green color of the Scotch fir. And jet his art, or his skill in the exercise of it, has to bear the blame of these errors! It would be almost as reasonable to expect a fine land. scape-painting, were we to commission an artist to trace the outlines of the picture, and then to leave the coloring, the management of the lights and shades, and the filling-up generally, to a loouse-painter, who undoubtedly can handle a brush as well as a forester or a day-laborer can wield a spade.

Note.-Our anthor talks well, and refinedly, like all writers and planters who write and plant in a country where nature has not bountifully supplied it with natural subjects of cultivation. But it is not so in America. The ingenuity of man can conceive of nothing half so grand, so varied, and so beantiful, as a diversified American forest during the summer and autumn. Take, for instance, the breast of one of our fine hill or mountain ranges of forest, where the evergreen and deciduous trees, of great variety and luxnriant growth, commingle in one broad, continued bank of parti-culored verdure, at the first bursting of their new leaves in the epring, and in their successive growth throngh the summer. What delicate tints ware and lift their perpetual changes, from the deep blne-green of the hemlock to the poplars and beech, contrasting with the silvery tints of the white maple, 
the fixed, unchangeable green of the oak and the pine, those models of strength and endurance! And after the frosts of antumn have tonched them, what roods on earth can compare with the gorgeous tints and colors of the deciduous leaves, relieved and supported by the unchanging hue of the evergreens? From the airy, lemon tints of the poplar and sugar maple, running down into the deep orange of the hickory; firom the liveliest searlet of the soft maples, to the mellow russet of the oaks and the ashs, in all their variety; each and every one soft and beautiful for many days, sometimes for weeks, our forests present a brilliancy and a grandeur unsurpassable in their kind.

It is not at all necessary for the American to go into the refinement and the particularity of the English planter to effect his object. Our mixed, natural forests supply the best expression possible to park and forest scenery, in tree and shrub. All we have to do, where not furnished by the undisturbed hand of nature herself, is, to imitate her in the blandest and most agreeable forms within our power; and in whatever we add, by way of exotic, let us be sure that no exaggerated contrast is presented to the harmony of our own luxuriant productions.-ED. 


\title{
CHAPTER VI.
}

\author{
PLANTING.
}

Preparation of the Ground - Trenching - Draining - Ruads through Plantations - Planting of Forest Trees - Pitting - Pruning - Thinning - Transplanting Forest Trees - Planting and Transplanting of Evergreens.

WE have already adverted to the importance of planting in the formation and improvement of parks and pleasure-grounds. In these interesting appendages of a country residence, the woods present a main element of beauty; and the degree of that beauty is mainly dependent on the healthy and luxuriant growth of the trees. With these facts in view, we shall offer some brief remarks on the planting, fencing, and after-management of plantations, confining ourselves, at the same time, to those subjects which have a close relation to the park and dressed grounds.

Preparation of tile Ground.-This is a matter which has been much discussed, and has led to the expression of a variety of opinions. Some have thought that a very careful preparation of the land is indispensable; others would content themselves with draining, and the removal of furze and other impediments to the growth of the trees. Both these opinions will hold good in their proper places, or in relation to 
different localities. Our own experience lias led to the conclusion that operose preparations, such as trenching or plougling, are in general not required beyond the park, and that the expensive operation of trenching may be confined to the circle of the dressed grounds.

The principal advantage of trenching and plonghing is their effect in accelerating the growth of the trees, particularly in their earlier stages, and the consequent rapidity in the development of the scenery - a matter of no small impurtance to gentlemen who wish to see and enjoy the result of their own labors. This effect is generally very marked in the interval between the fifth and fifteenth year from the planting: at a later period, and on good land, it is much less perceptible.

Trenching is undoubtedly the best means of preparing ground for planting; but as it costs from six to ten pounds sterling per acre, it is too expensive to be extensirely adopted. As a substitute, we have found a method of deep plowing, particularly on grass lands, to be very useful. Two plows are required for the operation, which closely resembles subsoil plowing. A deep furrow is first drawn. The first plow next skims off some two or three inches of the turf and soil, turning it orer into the open furrow. The second plow then follows in the same furrow as the first plow, covering the turf with four or five inches of soil, and stirring the land to the depth of seven or eight inches. By this means the soil is well pulverized, and the turf is so buried as to insure its rotting, and thus affords an excellent manure for the trees. The expense is about twenty-four shillings per acre.

Draining of wet land is essential to successful planting, and is not to be superseded by any other operation, 
although, on trenched grounds, the drains may be placed at greater distances from each other. In large plantations the drains are always open, and may be laid down at intervals of sixteen to forty-eight feet, according to the porosity of the ground. In many places of the park open drains are inadmissible; and in these cases we prefer box drains, formed with stones, as much less liable to be choked up with roots of trees than tile-pipes or tiles and soles certainly are.

Ronds throdgi Plantations.-Roads, or rides, as they are frequently called, are needful in large plantations. Though used for carts and carriages, they are in most cases only grass walks, fifteen, twenty, or thirty feet wide, with open ditehes on each side. Where the ground is soft, it may be necessary to lay a portion of the center with road-metal or gravel; and in hollows, it is useful to lay a box-drain across the line of road, and communicating with one of the main drains. The open drains on the sides should not be deep, and should never be main drains. In extensire woods, we would form some of the leading rides at donble the width of those nentioned above; it is in such open spaces that we generally lave the appearance of ornamental scenery. Or we would occasionally expand them into broad lawns and glades, and also form bays and recesses along their borders. These open spaces, besides being highly picturesque, afford good feeding-grounds for game.

Plantixg of Forest 'Trees.-The differences of opinion which exist, as to the best method of planting, the distances between the trees, and the most suitable season for the work, afford sufficient proof that there is room for a variety of treatment-a fortunate 
circumstance when the planting is extensive, as it enables the improver to have his work better executed than it would be were he obligel to confine his operations to a few wecks at a time. Six months in winter, inclusive of Norember and April, are the ntmost limits within whieh planting may be hazarded. Indeed, April and one half of March should be excluded, except in late seasons, or in highl, cold, and wet grounds. On light, dry soils, the best season is at the begiuning of winter; and on heavy and moist situations, toward its close. Very wet, snowy, or frosty weather presents the only interruptions to the progress of planting; in some years, these will reduce the planting season to within lialf the period stated above.

Pitring, though the most expensive, is the most certain method of planting, and therefore should be adopted in the woods of the park. The only allowable exception to this rule, would be the usc of the slit or T manner of inserting the trees; which, in exposed localities, and with seedlings, will less subject the plants to wind-waving, and so will be more successful than ordinary pitting. The trees may be planted at from three and a half to four and a half feet apart, according to the soil and situation - these distances including both the nursing and the principal trees. In hardwood plantations, such intervals will place the trees from seven feet to nine feet apart. Larch, spruce, and Scotch firs make excellent nurses, and are extremely useful in yielding shelter, and in drawiug up the hardwood into tall, clean trunks. Ir: sheltered situations, and in good soils, such nurses may be omitted. Masses of hardwood are sometimes required to produce particular effects, and in these cases it is 
better to prevent the possibility of firs becoming principals, to the injury of the scenery. With this view, we have had hardwood, without firs, planted in masses at four or four and a half feet apart.

Pruning.- In the culture of forest trees, pruning is, after pianting, the most important operation. Its object is the production of a large trimk or bole of clean, sound timber; and to accomplish this, the tree is to be pruned so as to lead to the accmmulation of the principal bulk of the ligneous matter in the main stem. This aim should be distinctly kept in view, in every operation, whether in the removal or shortening of the branches. Reduced to this general prineiple, pruning is diyested of all difficulty, at least when it is commenced at an early period, and is regularly and carefully prosecuted. After a shoot has been selected for the main stem, all other shoots, which indicate a tendency to draw off from it the leading growth, shonld be shortened or removed. For some year's after planting, it will be, for the most part, sufficient to foreshorten; that is, to cut back the side-shoots from onethird to two-thirds of their length, in order to discomrage their growth in a lateral direction; but this is on the supposition that the trees lave taken with the ground, and are in a thriving state. Where hardwood does not appear to thrive by the end of the secoud, or at most the third season from planting, it is advisable, in the following spring, to cut the trees to the ground; the result will be a number of rigorous shoots, of which one should be selected for the future tree, and the other's removed.

Where a plantation has grown well by the end of the sixth or seventh year from planting, in addition to 
the pruning already recommended, the branches formerly foreshortened should be cut off at the lower part of the stem; leaving it bare, at first, not abore one-sixth, or at most one-fitth, the height of the tree. By the time, however, that the tree is from fifteen to twenty feet high, it may have a clear stem of onethird its height, and varying from one-third to one-lialf when the tree has attained a stature of thirty feet. These remarks are not meant to apply in all cases, in the park and pleasure-grounds, where the natural appearance of many trees would be spoiled by the removal of branches from their trunks for more than ten or fifteen feet. Some trees, however, are improved by the partial thinning and shortening of the branches to double that height. When pruning should begin, and how often it should be resorted to, must be left to the discretion "of the proprietor, judging from the growtl of the trees. Some plantations will be benefited by in careful examination and pruning erery second year; others will require attention only every fourth or fifth year. Some excellent foresters condemn the periodical pruning of woods. Our own experience is, that it is advantageous to examine the trees in the park every second or third year; of course, pruning only those trees that require it, and cutting back the branches of the nurses which are pressing on the principals. We agree with Mr. Brown, in his useful work, "The Forester," that pruning should precede thinning by at least one year. When both operations go on together, the growth of the young trees is apt to be checked by their sudden exposure to the colder atmosphere, consequent on the decrease of shelter. Fir-trees should be planted so thickly as to prune themselves, the dead 
branches being carefully removed as they appear. On the lawns of the pleasure-ground, some firs are disposed to extend their lower branches too far. To counteract this tendency, and to throw the strength of the tree into the main stem, the terminal bud or shoot of the lower branches is to be pinched off. Cedars, and other spreading firs, treated in this way, may be made to assume an upright form.

Thinning.-Thimning is an operation nearly as necessary as pruning, and in fir plantations perhaps the more necessary of the two. As young woods are generally planted more densely than is needful for their permanent condition, in order that the young trees may produce a shelter for each other, and a corresponding warmth in the climate, the period selected for thinning the young plantations should vary with the progress of the trees, as that again will vary with the soil and climate in which they grow. Some plantations may receire a partial thinning by the time they have been seven or eight years planted; others, in more exposed places, may not require the same sort of thinning till they are double that age.

In the process of thinning, it should be distinctly liept in mind that the trees which are removed were originally planted to shelter and draw up the trees which are to remain, and that only those are to be cleared away, from time to time, which are doing injury to those designed to be permanent. When this principle is made to regulate the work, there is little danger that thinning will be carried to an injurious excess. Nothing is more prejudicial than excessive thinning. The bark of those trees which have been well sheltered by close planting is less dense, and 
more sensitive to cold, than that of trees exposed to all weathers, and their roots are much fewer, and have a slighter hold of the ground. It is evident, therefore, that the trees left standing in over-thinned plantations, being ill-prepared for their new circumstances, are sure to receive a severe check; which, if it does not kill them outright, will retard their growth for many years, or stunt them to an extent from which they may never recover.

The thinning of fir plantations need not begin before the trees press so much on each other as not only to eheck the growth of the lower branches, but also to kill a portion of those next the ground.

In hardwood plantations, the thinning commences when the nurses press so much on the permanent trees as really to injure them; but only such trees should be removed as actually do so. When the pressure is slight, it may be relieved by cutting back the nurses to half their length, and they may be allowed to remain till the adrance of the hardwood requires their entire removal. From the time that all the nurses are removed, in each of the subsequent thinnings which are necessary to leare the permanent trees that are suitable for the formation of large timber, those trees should first be cut down which appear to press on their stronger and more healthy neighbors, and to deprive them of the room and nourishment needful to their increasing growth.

Transplantivg of Trees. - In the improvement of the park and pleasure-grounds, much may be effected by the transplantation of trees of a considerable size. Where suitable trees are to be had, they may often be effectively employed in the formation of groups in the 
lawns and in the park, or in making up masses of wood, to shut out disagreeable views or unsightly objects. As, in such operations, immediate effect is the principal object aimed at, it is a matter of the utmost importance that the work of transplantation should be performed with such care and success that the trees should not, only live, but also recover their vigorous growth and healthy appearance, within two or three years after their removal. This, with trees from twenty to forty feet high, is usually a result of somewhat difficult attainment. The most propitious season for transplanting deciduous trees we have found to be in September*, while the foliage was still green, but the young wood firm and ripening off. Young rootlets are almost sure to be formed befor e winter, through which the tree receives an imrediate supply of sap in spring; while later-planted trees often continue withering in the wind till roots are put forth in the beginning of summer. Proper subjects for transplanting should be selected; the best are found growing, if not in exposed, at least in wellaired localities; such as on the outsides of plantations, with branches tolerably well-balanced, and having a copious supply of roots. Trees from these situations, and with these qualities, are more hardy and better able than any others to stand the increased exposure arising from their being planted as single trees, or in thin groups. If trees can not be obtained, as above recommended, recourse must be had to the interior of plantations; but they should be prepared, by thinning and the consequent exposure, before they are removed.

- Not in the United States; October and November are better months for autumn, and Jlarch and Apruf for spring planting.-ED. 
It is generally worse than nseless, to transplant fecble drawn-np trees, from close-sheltered thickets, into the position of single trees or groups; for, although they may survive the check sustained from the necessary loss of roots, and the inereased cold, not one in ten will ever form a fine tree. We may add, that though trees may often be transplanted at once, success is more eertain when they have been prepared by havings. their roots ent two or three years before their removal. This is done by digging a trench round the tree, at the distance of from two to four feet firom the trunk, according to the size, and to the depth of from eighteen to thirty inches, so that all the spreading. roots may be cut through, and the deseending roots left untouched for the present. When the roots are abundant, three or four of the principal ones should be left undiviled till the period of transplantation; or they may be cut at the distance of three or four feet beyond the trench. These reserved roots will afford the tree a better hold of the ground when lifted, while the shortened roots will yield a copious supply of fibers with which to commence its renewed growtl. When the suil is ordinary quality, it may be replaced in the trench; if it is very inferior, or if there are but few routs or fiber's within the ball left by the cutting, some prepared soil may be introduced. Generally, however, this is unnecessary, and we prefer keeping the enriched earth to be put round the ball and among the young fibers, at the time when the tree is placed in its new site.

The remoral of large trees requires the assistance of machinery, horses, and a number of men. The common two-wheeled Janker, with its single pole and 
truss fixed on the center of the axle, is the least expensive, and, at the same time, the most convenient machine. As the trees, when placed on it, lie on their sicle, a little management is required to jreserve the branches from being injured by trailing on the ground. We have found the Janker sufficient for ordinary purposes. The Elvaston machine is a more expensive one, but is nndoubtedly a more efficient aid in transplantation; the trees are moved with larger and better balls, and the branches are preserved from injury by the trunks being kept ereet.

Note.-The transplanting of trees more than four inches in diameter at the base of the trunk or collar, without a large ball of earth adhering to the roots, is of little use in our American climate. With the ball of earth at the roots carefully taken up, and loaded on to a sled or stone-boat, the operation may be successfully performed, and the tree saved by mulching with barn litter, sawdust, or tanbark.-Ev.

When the tree is placed in its new site, it is most important that it should be properly and securely fixed. To accomplish this object, the earth should be rammed in firmly below the ball, so as to give the root a solid seat, and to prevent the roots from moving when the npper part of the tree is aeted on by the wind. The roots and fibers should then be earefully laid out, and covered with fresh loam or enriched soil. When the earth is made up nearly to the natural level of the ground, three strong wooden pins, six or eight inches in diameter, should be driven down to the same level, near the outside of the hole, and forming a triangle, with the tree in the eenter. To these pins are to be nailed three strong slabs of rood, completing 
the sides of the triangle, and laying fast hold on the ball or principal roots of the tree. The operation is then finished by filling up and beating in the earth to the lerel of the surface. Trees so planted will resist almost any amount of wind, and be firee from the unsightly appliances of stakes, props, ropes, and heaps of stones, often placed round them to maintain their upright position.

Plasting and Transplanting of Evergreens.The distribution of evergreen trees and shrubs is among the most interesting operations in the formation and improvement of pleasure-grounds; in the first, they gire at once a clothed appearance to what was bare ground; and in the second, by their change of position they effect an almost entire alteration in the scenery of the place. Success, however, requires not only careful execution, but also due attention to the proper seasons for the performance of the work.

In all cases, it is adrisable that the ground should be well drained and trenched; and where poor, it should be enriched with fresh soil or manure, or both, especially when the shrubs are young and small. Light sandy soils are greatly improved by moderate additions of clayey loam or peat earth. In transplanting shrubs of considerable size, we prefer putting the enriched soil or manure close round the ball, and in contact with the young fibers. In such cases, too, it is useful to prepare the plants, by cutting a trench round them, a year or two previously, as recommended in relation to forest trees.

In lifting evergreen slurubs for transplantation, as many roots as possible should be preserved. When they are large, or a little above the size nsmally $\mathrm{S*}$ 
procurable from nurseries, they should have good balls; and if these can not be secured, at least to a moderate extent, it will be proper to reduce the head of the plant, as otherwise many of the branches will die back, from their inability to support their former amount of foliage. Perhaps this thinning ont of the branches should be resorted to in all cases when large shrubs are shifted; but it is less necessary when the balls are large, and the roots are well prepared. For the most part, there is good economy in the moderate use of the knife, both in respect of time and of appearance.

All shrubs, and especially large ones, should have au ample supply of water when they are transplanted, and this is most effectively given when the water is run into the new pit in which the plant is placed, along with the filling-in of the earth, beginning when the pit is about one-fourth filled, and continuing till it is nearly quite full. The quantity of the water should be such as to form a strong puddle round the ball. This mode of watering keeps the roots moist, as well as consolidates the earth about them; and if carefully done at first, will scarcely require any additions. If the water is not administered till after the earth has been fully pressed in round the roots, frequent repetition and larger quantities will be necessary, and the same beneficial results will not be attained.

There has been much difference of opinion, and many discussions, respecting the most suitable season for transplanting evergreen shrubs. Some recommend the autumn months, others the winter and spring. When the operations are extensive, it may at times be necessary to carry on the work during the whole period, 
and if frosty and withering weather is avoided, the planting may be successful.

Note.-The winters of Great Britain are so mild that the frosts are seldom an impediment to planting, in either of the winter months. In our Middle and Northern states, the winter season is unsuited for planting trees of any kind.-ED.

It is admitted by all, that the transplanting of evergreens should not be attempted when the plants are in full growth; for, though even then they may survive the shock, the chance is that most of them will perish or die down to the ground. It seems also ascertained, that the loss of evergreens when transplanted is caused by the excess of perspiration from their leaves, compared with the quantity of sap taken up by their mutilated roots; and that, consequently, dry, parching weather, at whaterer senson it oceurs, is, other things being equal, the most unpropitious for the operations to which we are now adrerting. At first sight, this principle might seem to exclude the end of summer and early autumn from the seasons arailable for planting; and yet it does not, and that for various reasons. At the period to which we have referred, there is much warmth in the suil, and as the perfeeted sap is then descending from the leaves, the growtlı of roots eommences rapidly and goes on to a considerable extent, in which case the plant is soon ont of danger. Then there is often cloudy and dripping weather, after the turn of the day, as it is called, and every one must have remarked the greater geniality of that season in regard to growth, as compared with spring. Besides, in the spring months, the soil is colder and the 
atmosphere is drier than in antunn, as may be seen from the table on the opposite page.

The conclusions to be derived from those tables plainly point out autumn as the best period for the transplanting of evergreens; and yet, when rightly considered, they admit of that wide range of time which actual experience authenticates. We believe that evergreens, in small quantities, have been safely transplanted from midsummer to the end of $A$ pril perhaps we might say the whole year round. This has occurred from a compensation of adrantages and disadvantages. Take August, for example: the air is then drier than it is two months later, but the soil is warmer; and if the plants eseape a blazing sun for a few clays, the growth of roots will commence, and will very speedily supply to the leaves all the perspirable matter that is needed. Thus, an equilibrium of action is rapidly established. In December or January again, supposing frost to be absent, in which case alone the comparison is possible, the evaporation is diminished, but the warmth of the soil is also lowered, and the transplanted evergreen is apparently in similar circumEtances as befure; and yet it is not so finorably situated, since it wants the establishing influences of the antumn months before it is required to encounter the severities of spring. It must be added, however, that in mild, moist winters and springs there is often sufficient warmth in the soil to promote the growth of ronts; and at these times, if the weather is such as to prevent excess of evaporation, the transplantation may be completely successful.

In the colder distriets, there are sometimes pro. tracted frosts, lasting, perhaps, from December to 
PLANTIYG AND TRANSPLANTING EVERGREENS. 181

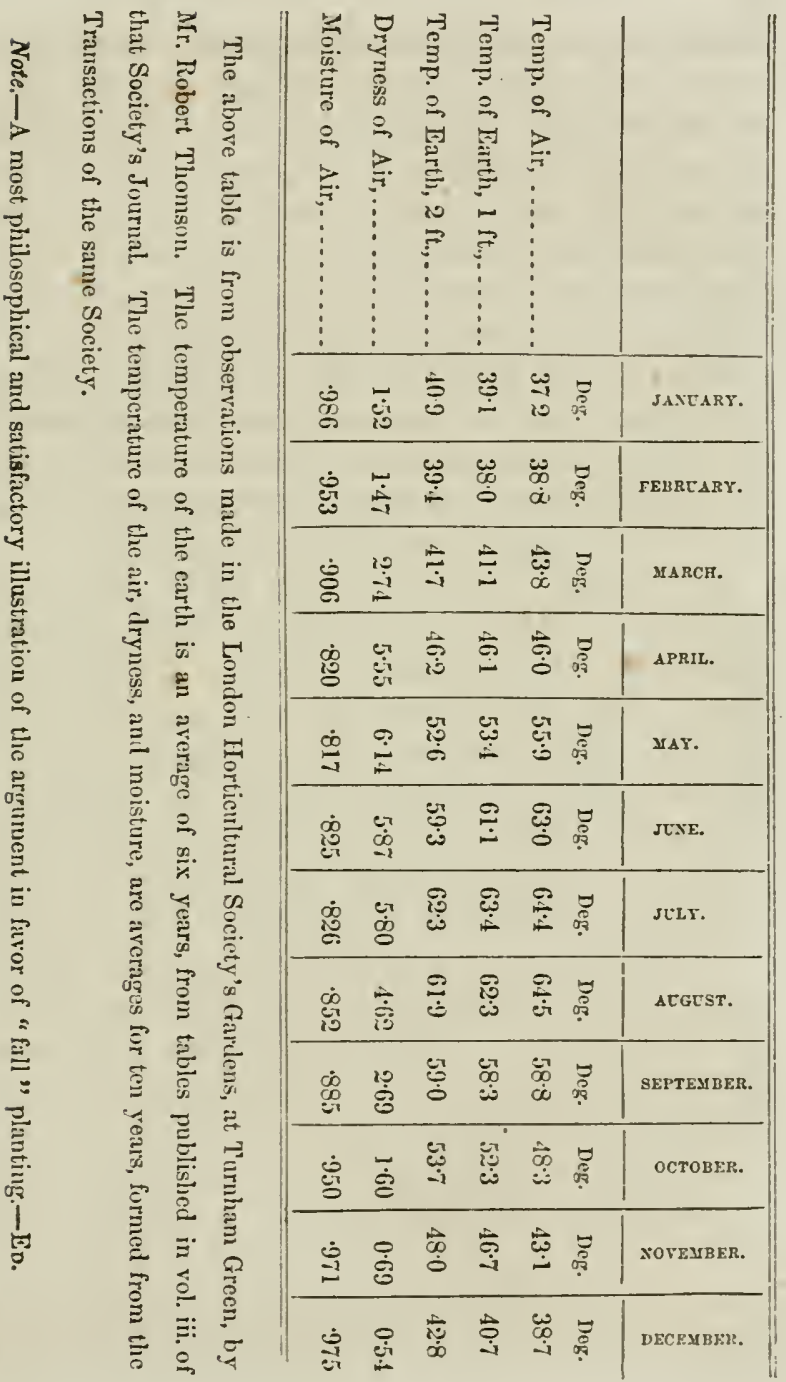


March, during which the air becomes extremely dy, and if it is set in motion by northerly or easterly winds, its effect is rapidly destructire to all evergreens, though long established, if less hardy than the holly or yew. By such a wind, even "the iry nerer sere" is changed into a russet-brown. We can not wonder, then, that an arbutns or a sweet bay shonld wither visibly before it; and it will at once be perceived, that weather which thus goes far to destroy established evergreens must be absolntely pernicious to those enfeebled by recent planting. The remark will suggest the consideration of shelter for evergreens, in connection with the proper season for their removal.

Dr. Lindley concludes an able article on the transplanting of shrubs by saying, that "Upon the whole, September, October, and Norember should be preferred - one being better in one year, and one in another. We shall ouly add, that a ground temperature of forty-seven degrees, which may be taken as that of thoroughly drained land near London, in Norember, is sufficiently high for plants to form their roots in." (Gardeners' Chronicle, January 6tl, 1549.)

Referring to our own experience, we have had evergreen shrubs successfully transplanted fiom the middle of July to the middle of April, but only in small quantities in the months of July, March, and April. We believe that September, October, and November form the most suitable seasons in the middle districts of the island - allowing, perhaps, a fortnight earlier for the northern, and a fortnight later for the southern parts of Great Britain. In the mild climates of Ireland, the planting may be freely continued during the whole of the antumn, winter, and spring months. But 
PLANTING AND TRANSPLANING EYERGREENS. 183

in no circumstances should evergreens be moved in hot, dry sunshine, in eold, parehing winds, or in aetual frost; at such times, the roots and foliage are sure to suffer while they are out of the ground. Further, it is not generally advisable to shift them before the annual shoots are somewhat ripened, in antumn.

Note.-The subjects eomprised in this ebapter being chiefly of a professional eharacter, and equally applicable to this country as to Great Britain, it is only necessary to refer those who wish to arail themselves of its instruction to a close and discriminating study of every department discussed by our author.-ED. 


\section{CHAPTER VII.}

FENCES OF THE PARK AND PLEASURE-GROUNDS.

General Remarks - Boundary Fence - Internal Fences - Fence of the

Deer Park-Pleasure-Ground Fences-Malleable-iron Fences Sunk Fences - Stone Walls - Hedges.

Boти in its original signification and actual usage, the term, Park, denotes an inclosed space. The park, therefore, is always encircled by a boundary or ring fence, of suflicient height to afford protection from without, to retain in their proper places "the beasts of chase," or the cattle that may be kept within it, and to insure that moderate seclusion which is an essential requisite to a country residence, in the estimation both of its inmates and of those strangers whom the liberality of the proprietor permits to visit and enjoy its scenery. Besides this bounding inclosure, however, internal or divisional fences are necessary. A park of many hundred acres, and including a multiplicity of objects, invariably requires to be subdivided into lesser portions, for the convenience of grazing, and for other reasons, such as the separation of certain of the wooded surfaces from the pasture-grounds, and the due regulation of the secondary roads, and even sometimes of the main approach. We shall take up these two classes of fences in succession. 
Boundary Fence.-The outline and position of this fence depend on those of the park itself, and seldom call for much attention except where it thrusts itself obtrusively on the eye, a circumstance to be guarded against or ameliorated when possible. The fence itself is often a wall built of stone, or, if that material is scarce, of bricks; and it may be from six and a half feet to nine feet in height. On flat surfaces, fences of this altitude shit out much of the surronnding comtry; and in such cases, when it is desirable to extend the view to the adjacent portion of the estate, insteack of the wall may be substitnted a sunk fence, with the fosse or trench on the outside. Where timber is abundant, wooden fences are occasionally employed; but unless of moderate extent, their want of durability renders them less desirable than those formed of more permanent materials. A close, tall pale of split oak, however, is very serviceable, and will last for upward of thirty years. Hedges seldom prove effieient boundaries; when, howerer, combined with walls, and well trained and kept, they may suffice for parks in thinly populated districts. The walls may be two or three feet high, with a low bank of earth behind, on which to plant the hedge.

Internal Fexces.-The proper arrangement of the divisional fences in the interior of the park is a matter of considerable dificulty, and one in which there are perhaps more failures than in almost any other. The common error is the application of the principles of ordinary farm fencing to the ornamental grounds. In purely agricultural districts the divisions are arranged so as to facilitate drainage, and to suit the eonveniences of tillage. The normal type of the agrieultnral field 
is a square or parallelogram; but these forms can scarcely be introduced into the park, at least visibly, without a wretched effect. Many parks are subdivided by such a multiplicity of hedges and walls as to deprive them of all apparent continuity of surfice, and therefore of that unity which is always so desirable. We have often scen the contour of a sinall hill lestroyed by a hedge planted along its top, the slope of a fine bank interrupted by a wall run up or across its breast, or what is perhaps even worse, the bottom of a small and beantiful valley crossed and recrossed by hedge and ditch or dry stone wall, to the utter destruction of the natural beauty of the locality. Clearly, the internal fences of the park should be so arranged as to avoid these barbarously mutilating divisions of surfaces. Indeed, could the woods be reared for the first forty or fifty year's without fences, there might be an almost total absence of that formality and interference witl contour so common in most parks; and there would be much more of that free irregularity of outline which is so characteristic a feature in the grouping of the natural forest. But as we have already said, internal fences in the park cannot be dispensed with; yet, in relation to the general scenery, they should be regarded as necessary evils, and those forms and distributions of them should be preferred which are least conspicuous and obtrusive. Lines should be adopted which accommodate themselves to the form of the gromud, or which may be most easily masked or relieved with seattered trees. With these objects in view, the inclosures of the woods and clumps may be made to form a considerable portion of the divisional fences of the park. 
Fence of the Deer Park.--Deer parks require fences equal to the best description of park walls. When they are placed contignous to the external boundary of the home domain, a considerable amount of soparate fencing unust be dispensed with. As a division from the other portions of the park, a welllaid-out, sunk fence-wall, of medium height, with a wire fence along the top, will be found to be sufficient.

Note-Deer, in the United States, cost more than they come to. The fallow deer of England do not withstand the vicissitudes of our climate, and the American deer are too wild, and leap too high, to be favorites with our park proprietors. Well bred cattle and sheep are better.-ED.

Pleasure-ground Fences. - In immediate connection with the mansion-honse, and especially where there is only a limited extent of dressed grounds between it and the park, the most appropriate fence is an architectural one of the same materials, and in the same style, as the principal buildings. In no case should this fence be raised much above the general surface, otherwise the view of the external scenery may be greatly intercepted. In flat situations, and where the principal rooms are raised only a few steps above the ground level, wire fences are commonly the most suitable. The proper seclusion of the pleasuregrounds will often require a wall of six or seven feet in height, to separate them, for example, from the back-road to the house and offices. Such a wall, however, should hardly ever eross the views from the principal windows. In these places, a sunk fence, or a wire fence, should generally be substituted.

Matreable Iron Fences, such as those made of 
wire and small iron rods for the use of the park, come nearer to perfection than any others. We consider them the greatest improvement introduced into this department of feneing during the last hundred years. Their light and simple forms interposing a small amount of opaque matter between the eye and objects beyond, render them nearly invisible; and when formed of proper materials, and well constructed, they are very durable, and as effieient as a fence can well be. The use of iron rods screwed into each other, in place of the top wire and of the third wire from the ground, improves greatly the common wire fence. We lately inspected a fence of this description which had stood thirty-three years, and found it perfectly sound, and likely to last for as long a period to come. Instead of the above, iron hurdle-fences are sometimes used, and, being more movable, have their conreniences in certain situations. Wire fences with wooden posts are at present pretty extensively used. In relation to agricultural purposes, we have nothing to say against them; but we confess that we regard them as offensive in the park, and we should employ them only as temporary expedients. At a distance, they appear an array of wooden stumps stuck into the ground, withont visible utility or connection; and on flat surfaces, where several lines may be seen together, they are at once mean and monotonous.

Surk Fences have been generally superseded by wire fences; there are, however, some positions in which the former are preferable, as we have pointed ont when speaking of the boundary and deer-park inclosures. The proper place of the sunk fence in the park is where a sectional division is wanted, while it 
is desirable to preserve an apparent continuity of outline in a glade, or an expanse of grass on a level or elightly inclined surface, on which, perhaps, eren the inconsiderable constraint of a wire fence miglit be objectionable. The wall of the sunk fence shonld never race the principal point of view; and from such points it is not an adrantage for the line of direction to be seen on end, and so to be enfiladed by the eye. $A$ low wall, thirty inches in height, forming al sunk fence two feet in depth, with two wires along the top, affords a good, cheap protection for plantations where stones are abmudant.

Stone Walls are good permanent fences; but on flat or slightly undulating surfaces, they often hide a considerable breadth of view, especially when employed as internal dirisions. For plantations they are less objectionable, as the trees orerhang and rail them. They are best suited for hilly and mountainors countries, and in these they may be freely employed, as the objections which may be made against walls in other places are there less applicable.

HeDGes afford a cheap sort of fence.* They are not, lowerer, generally speaking, very suitable for the park; for however neatly they may be cut and dressed, it is needful, when they form the boundaries of clumps or plantations, to keep the trees trimmed back, in order to prevent them from injuring the hedges, and so they impart a more formal and constrained outline to growing rood than almost any other species of fence does. Hedges may be planted with good effect on the inside of the boundary walls of the park, to clothe them when they are not screened by plantations.

- Not in this country.-ED. 
Note-Necessity, not choicc, must rule the character of fences to a considerable extent in America. In ornamental grounds, when stone can be had, the ha-ha, or sunken wall, with a sloping ditch bank facing it, is the most appropriate, and may be made efficient for usual purposes. By this mode, the unsightly appearance of ordinary fences is superseded. The lawn and park of the late Gardiner G. Howland, near New Hamburgh, on the Hudson, designed and planted, and for some years occupied, by James Lenox, Esq., of New York, as well as those of Mr. Sheafe, on the elevated lands adjoining, exhibit fine specimens of the unbroken effect which such places may produce in the absence of fences, none being visible within the boundaries. Where so great a variety of fencing material is resorted to, as with us, local convenience, and expense, must measurably govern the kind to be nsed. The perishable nature of wood, and its inreasing scarcity, will soon compel us to resort to other materials in districts where stone is not to be procured. Wire has been successfully introduced in some sections of the country, and hedges are-talked of. Although these latter are advocated by some, a permanently efficient hedge: inclosing an entire park, pleasure-ground. or agrieultural estate, has not jet come to our notice. Hedges may, in time, be introduced, and perhaps to good purpose; but we are somewhat donbtfin of their adoption to any considerable extent, save, perhaps, in the use of Osage Orange, on the western prairies. The subject of fences, therefore, for the present object, must be left to the convenience and circumstances of the land and its proprietor.-ED. 


\section{CHA P TER VIII.}

WATER.

Artiticial Lakes - Islands - The Head or Artificial Embankment -

Decoratire Accompaniments - Artificial Rirers - Jet Fountains Jets d'Eau - Propriety of Introducing Water.

Or all the varied materials in the composition of natural scenery, there is none that produces more beauty, variety and interest than water; nor is there any that enters into so many pleasing combinations with surrounding objects. This felicity in adjusting itself to the beautiful in nature awakens a strong desire for the introduction of so pleasing an element into the more artificial arrangements of parks and pleasure-grounds. In these it assumes a diversity of forms, such as artificial lakes, ponds, rivers, waterfalls, fountains, and jets d'eau - means of ornament which, when skillfully executed and kept in their proper places, are always a great acquisition to the grounds into which they are introduced.

In the formation of an ARTIFICIAL LAKE there are two requisites of almost equal importance. The first is an arlequate supply of water, withont which, indeed, we may make a morass or weedy pool, but not a pleasing sheet of the liquid element. The second, and not inferion object is a suitable site for the lake. If the locality does not convey the impression that the water 
is resting in a hollow, vale or platform, and is retained there by a natural obstruction not easily removed, there will be "a want of truth or fidelity" of expression in relation to "the thing imitated" that will tend to excite aversion rather than pleasure in the minds of those who have been trained to a genuine taste for the beauties of nature. Wherever the artificial lake is seen, generally speaking, it ought to appear in the lowest part of the landscape within the park; or if it cannot be made to present this appearance from every point of view, care should be taken to secure a considerable breadth of space between the lake itself and the natural outlet by which its waters seem to be drained off. Without these necessary features, there is a want of truthfnlness in the expression. It is true that in hilly and mountainous countries, pools are found without the conditions above specified, but there is always something to account for them, and they are mostly mere spots in the landscape; while in parks and pleasure-grounds, sheets of water are, from their nature, prominent objects, and whatever is obtrusively artificial or out of harmony is sme to be offensive. When a series of ponds or lakes are formed on the same stream, and in the same park, it is desirable that the natural form of the ground should be such as to indicate that, in each case, no great amount of obstruction was necessary to attain the designed effect.

The place, then, for an artificial lake is a natural hollow where no great embankment is required, or where a moderate excavation will afford materials for the banks needed to retain the water, for the islands and promontories on the lake itself, and for the knolls and slopes by which the ground in its vicinity may be 
varied. The opposite extreme, lowerer, shuuld be avoided; for where there is too little excavation, the boundaries of the lake often seem too feeble for the retention of its contents, and the effect is inrariably tame. As a general rule, apparent shallowness should be aroided in artificial watter.

The beanty of lakes depends greatly on their outline, and this, therefore, is an object of indispensable attention. When they are formed in a hollow, the plane of their waters naturally assumes an outline corresponding with the original configuration of the ground, and this outline ean be raried and improved only by the formation of bays, promontories and islands; and by such means considerable additional effect may often be produced. If the site is ou lerel ground, the outline may be varied at pleasure; any form may be adopted. It may be either broad, bending, or winding, as the general clraracter of the park or the extent of the lake will allow. In every ease, however, the artificial lake should present breadth rather than length. Variety of outline, and the desirable intricacy of effect, may be secured by the means above alluded to, viz: by bays, and promontories, and islands. Care, howevir, must be taken that the projecting masses do not obs sure or destroy the breadth of surface, as is too often the ease with small pieces of water. In some instances, what is intended for a lake dwindles down into a winding canal, or palmated pool with an island stuck into it, certainly as unlike a work of nature as a work of man can be.

Note.-It is the sheerest folly to attempt water, unless some volume can be given to it. All attempts to make a duck pond in grounds of any extent, are little 
better than contemptible. The dignity of fine grounds should never be marred by a puddle.-ED.

IsLaxds should be irregular both in their outline and contour, and small rather than large. They are more advantageously placed near the sides or ends than in the center of the lake; at the same time they should not have the appearance of being separated from the main land only by a narrow canal. Their position should be determined by the outline of the lake and surrounding scenery; they ought never to be numerous. Their purpose is to impart variety to the water, and to obviate any apparent baldness in the banks, or to lessen other defects which cannot be removed by planting. Too many islands give an artificial shect of water the air of a map or model.

Note.-The park builder can not too strictly heed these instructions. We liave seen islands put into artificial water which the owners conceived to be a great achievement. But instead of things of beauty, as intended, they more resembled tussocs of grass floating in a wash-tub.-ED.

The HEan, as it is usually called - that is, the enbankment at the lower end of the lake for retaining the water-is generally one of the principal diffir ulties in the construction.* It is here that the artificial character of the lake is most conspicuous, and, of course, a greater effort is necessary to conceal it. When the head can be so formed as to unite with the form of the ground, and to present the appearance of

\footnotetext{
"In America we call this the "Dam." Our author commits a genuine "bull" in calling the "lower end" of any thing its "head." At the foot of the lake should be the dam, or embankment, to raise the water to its proper elevation; and where permanency is required, the strength of the dam can not be too thoroughly secured, particularly if the stream be liable to sudden floods.-ED.
} 
a natural obstruction, the success of the designer and executant may be regarded as complete. Heads of lakes, as usually formed, are commonly defective, being often too narrow; or when broad, of too little elevation, and are frequently, indeed, simple weirs for confining the water. When the lake occupies part of a small valley, the head may be formed into a knoll or two, thrown out from, but connected with, one of the banks; and the issuing stream may be led round the knoll, and between it and the opposite bank. When the locality requires a lengthened embankment, another method may be pursued. A broad mound may be constructed, either level or convex, with the water flowing through it, or following the course of a small, winding valley, scooped out at either end. In this case, the face of the raised platform toward the lake may be formed. into a series of terraces of parallel levels; and if these terraces are carried down the small valley and repeated in some of the adjacent bays, an inpression will be suggested that the lake is not an artificial creation, but that the rivulet has worked its way through the opposing bank, and left the water to form a new shore at a lower level. If the materials do not suffice to form a broad platform, either level or raised, a combination of the two forms may be employed, on a narrower base, by having a level next the water, and a raised bank for planting on the ontside. In speaking of the heads of artificial lakes, we have described only the projecting knoll and the broad platform. Natural examples of these may be seen in the lakes of hilly and undulating districts; they are easily imitated, and their imitations, if at all successful, have much less the appearance of artifice 
than the ridges of earth commonly employed for this purpose. To these might be added the rocky barrier and rugged outlet of a mountain lake; but as being at once extremely difficult to execute, and often in questionable taste, we do not renture to recommend them. It is a good principle, however, to look earnestly at nature when we are imitating its works. The ontline of the head toward the lake, admits of some variety of configuration. Where the broad platform is adopted, its edge may be in part a straight line, with curves toward the water at the ends; or, when the knoll is selected, a promontory may be drawn out into the water, with unequal bays at each side. The surplus water, instead of issuing throngh a pared overflow or sluice, should rather be conreyed in a winding stream, flowing from a bay at one end of the head; in this case, the small ralley forming the outlet should, if possible, be so excavated as to place the bed of the stream on the solid ground, not on the embankment, an arrangement conducive at once to stability and ornament. If a sluice is indispeneable, it should be in commection with a culvert.

When success has been attained in the form and ontline of an artificial lake, much still requires to be done in the way of decorative accompaniments. Water without wood will be destitute of that living grace which trees and shrubs can alone impart; and it will want, also, much of that varied reflection of light and shade, and of form and color, which adds so much charm and interest to woodland lakes. Trees, however, are not to be dotted over the banks. They should rather be combined into strong masses, at some places approaching the water's edge, at other's receding, and 
dispersed in irregular groups, as the surface of the ground may suggest. The embankments, when deficient in form, should be covered witl masses of wood. At the same time, it is injudicions to overload the scene with trees and shrubs. A light and graceful effect should be aimed at in certain positions, and a depth of shade in others. The pleasure-grounds and woods afford more suitable situations for highly ornamented pieces of water than the pasture-grounds in the park, as the latter are generally too unclothed for this purpose. Islands shonld not be over-thickly planted, as they commonly are. When the trees are sparse, they are more varied in their form, and fall into better groups. A green bank or piece of level lawn, seen from the neighboring shore, are agreeable features in an island. To lake scenery, a boat-house and pier, and palings running into the water to prevent deer and cattle from entering the reserved inclosures, and aquatic birds and plants, add a pleasing diversity.

Note.-The construction of lakes - ponds, as such small bodies of water are less euphonionsly called by us - is rather a delicate matter with park builders. Unless the circumstances and features of the adjoining grounds are farorably disposed, their exceedingly artificial look detracts from the effect they should produce. A sheet or stream of water should, of all things, look natural.-Ev.

To be properly seen, the lake requires to be approached by walks, especially in the pleasure-grounds. It is seldom advisable, however, to carry the walks quite round it. They should rather be directed to the points from which the finest views are seen. In this 
respect the head is generally important, for though it may not be the finest in itself, it often affords positions which exhibit other portions of the lake to greatest advantage. If, then, the head has been formed as above recommended, a walk may be led across it, keeping, however, on that side of the platform which is next the water. In no case should the walk pass close round the back of the embankment, as the descent from and subsequent ascent to the level of the lake, will undoubtedly proclaim to every one its artificial character. Such a cross-walk, if absolutely necessary, should always run at some considerable distance below, and through ground from which the head of the lake is masked by trees. Where more than one lake are formed in close proximity to each other, good taste will dictate that only one of these should be seen at the same time from the approach, if it passes near their points of separation.

Note-OOur author has treated this subject with goöd judgment, and in excellent taste. Perliaps there is no feature of the park or pleasure-ground more mismanaged, where it can be made available, than water. Better let it alone altogether than to fail in making it a graceful and attractive object in the picture. A sheet of water, in our climate, slould be deep and pure; otherwise it is little better than a nuisance, breeding noxious insects and reptiles.-ED.

Artiricial Rivers are sometimes formed in parks and pleasure-grounds, but seldom with happy effect. They want the progression and the continuance which are leading characteristics of natural rivers. The rivulets or streams which it is desired to elevate to the form of rivers, do not supply sufficient water to 
sustain the character aimed at; or if the breadth is increased to afford an adequate expanse, the movement of the water disappears, and the result is only a stagnant canal or an elongated pool. It is certainly better to lcave the stream in its natural state; or, if breadth of water is an object, to adopt the recommendation of Sir Uvedale Price, viz: to spread it out into a small lake, or chain of lakes, with the stream flowing through them.

Jet Fountains are more easily introduced into dressed gronnds than any other kind of ornamental water, at least where there is an adequate supply, and at a sufficient altitude in the source, within a moderate distance. Their effects are also more immediate, as they do not greatly depend on the growth of trees and shrubs, or other progressive improvements.

We believe that few objects can be used for the decoration of terraces and flower-gardens which are more generally pleasing than a well-arranged architectural fountain in full play. Such fountains should occupy conspicuons places in these localities; as, for example, the crossing of leading walks, or the center of a group of flower-beds. They are pleasing spectacles in themselves, but they always yield the most brilliant effect when surrounded with fine flowers and shrubs or trees.

A fountain, whether in full play or entirely. idle, may assume an intrinsic interest from the beauty of its design. When placed in the ricinity of the mansion-house, it should harmonize with the general style of the bnilding, or, at least, should exlibit no marked contrariety of character. In detached flower-gardens the style of the fountain is of less importance; still, 
eren there it should have some accordance with the expression of surrounding objects. Fountains are generally made of stone or iron. The former material seems preferable; but where light and fanciful shapes are wanted, iron or even glass may be employed.

Jets r'Ear are jet fountains on a large scale. In this country they are seldom seen in any other form than that of the nozzle of a strong pipe in the center of a pond, throring up a thick column of water to a considerable height. They are generally too large for terraces or flower-gardens. They may be introduced into some of the principal lawns in sight of the house, and in such situations, especially when partially backed or encompassed with trees, they are extremely brilliant and effective. It must be owned that there is seldom a supply of water copions enough to maintain such water-works in continuous action.

Besides the porver of introducing artificial water into a park or pleasure-ground, the propriety of so introducing it remains to be determined, and that is a matter sometimes requiring to be carefully weighed and considered. There are certain cases in which such attempts approach to manifest absurdity. It is possible, for example, to conceive a limited place with a mansion-house beautifully seated on an eminence, from which the ground slopes on at least three sides, and the whole of the kept grounds might be on these slopes. Water might undoubtedly be brought from the fourth side, and a fountain or two might be perfectly admissible, or even desirable; but certainly an artificial lake or river, or even pond, on the slopes, could be nothing less than ridiculous. It is, if possible, 
still more questionable taste to elaborate artificial shcets of water in sight of the sea, a fine inland lake, or navigable river. In these cases, the grand of nature invariably overpowers the puny efforts of art. We can not help associating the same feelings with jets d'eau; they do not harmonize at all with marine, and scarcely with lake scenery. If they must be introduced into such localities, let them be so placed that there may be no apparent competition between the tiny murmurs of their falling waters and the hoarser surge of the shore. In ordinary weather, there is as much spray from the curl of a wave over a small rock or considerable stone as from the finest fountain or jet d'eau. A young friend, who had recently inspected a water-power of this description playing in a flowergarden near the sea, farored us with the following lines descriptive of such artistic efforts:

Old Father Ocean merely sniled, To see this puny, earth-born child Send up its tiny stream of spray, To spurt and splutter for a day.

Note.-Jet fountains, and Jets d'Eau, we consider beneath the simple dignity of the park, or the extensive pleasure-ground. They are so entirely artificial in their character, and useless during our frosty months, that they may be classed with Spanish and Italian architecture, out-of-door statuary, and peacocks - from which, in fact, they should seldom be separated: Fountains and jets d'eau are sometimes desirable, and may be constructed with good effect under invit ing circumstances. They are exceedingly troublesome to keep in repair, where heary winter frosts prevail. $9 *$ 
Having indulged, for some years, in the play of a jet fountain in our own grounds, we know somewhat of this item belonging to it. MIost of the statuesque imagery through which the fomtains play in American grounds, is little short of monstrosity, or caricature. Instead of a deformed and unhappy looking piece of sculpture in the similitude of swan, goose, or other water-fowl; a dolphin, mermaid, or any piscatorial design; or even a classic imitation of any sort of humanity, through a distorted limb or feature of which the water may play, let the fabrication be some neat pattern of mechanic art in the way of iron or stone. Various models of these may be found in the shops of our principal cities, which are becoming and graceful ornaments.-Ep. 
GARDENS.

\section{H A P T E R IX.}

THE KITCHEN, FRUIT, AND FORCING GARDENS.

Introduction - The Site - Drainage - Soil - The Form - The Walls The Fruit Garden - The Forcing Garden.

GaRDEns intended for the production of fruit and culinary vegetables belong to the subject of horticulture, and therefore, in their full extent, do not come within the scope of this work. Their formation, as well as their culture, must be regulated by principles and methods specially belonging to them. They are, however, objects within the park, and bear certain relations to its component parts. If these relations are altogether neglected, the beauty of the surrounding scenery may be materially affected; and if they are exclusively attended to, the value of these gardens, in their proper character, may be greatly diminished. In laying out a country residence, a careful adjustment must be made between these competing claims. To aid these sometimes difficult arrangements, we propose in this chapter to offer some general observations, withont entering into lengthened or minute details.

The kitchen, fruit, and forcing gardens are generally so connected, and often so intermingled, as to form one establishment, and there is in them sucl a community of objects and operations as to warrant 
this union. In some cases, too, borders of flowers and of ornamental plants enter into the combination, and then they form what may be called mixed gardens. These mixed gardens are certainly finer than mere vegetable grounds, and they require a superior style of keeping; but when this system of combination is carried so far as to supersede the flower-garden proper, we think it greatly to be deprecated. In England the mixed garden is of rarer occurrence than in Scotland. In the latter country we not unfrequently neet with extensive parks in which there is no separate flowergarden, and where all the departinents of both horticulture and floriculture are jumbled together with much confusion. Undoubtedly a greater amount of ornamental effect results, but considerably less expense is incurred in keeping, when the last is wholly separated, or when, at nost, the fruit and kitchen-gardens only are placed together. In the following remarks, we shall not adrert further to the mixed garden, but shall confine our observations to those grounds which are exclusirely fitted and intended to yield a supply of fruit and vegetables - a matter of no small importance to a family residing in the country.

Site.-The primary consideration in reference to these gardens is their site, and more particularly its position in relation to the other parts of the park and grounds. Their unpicturesque appearance is such as to require that they should be screened, if not entirely hid, from the main points of view in the surrounding park, otherwise they prove detrimental to the general scenery. Certainly they should not be visible from the principal approach, nor from the windows of the mansion-house. In ordinary circumstances it is not 
expedient to remove them to too great a distance from the house, neither should they be placed altogrether in its immediate vicinity. Perhaps the most desirable position is one in a secluded part of the pleasuregrounds, where they call be set down in connection with each other, and where their walks can onter readily into the main system of communication rumning thronghont the place. In a locality of this description, their walls and other buildings ean be nost effectually shrouded, and on that account the general scenery will be least impaired. When the stables are detached from the mansion-house, the fruit and kitchen gardens may be placed near them, with advantage to the general arrangements of the place, as the same back-roads will serve for both, and facility of access will thus be increased.

In parks in which there are considerable eminences or ridges, the gardens in question are not unfrequently placed at the base of one or other of these, for the sake of shelter. Before adopting such a site however, the desigmer will do well to study the effect of that arrangement as viewed from the neighboring heights. There is scarcely any thing less pleasing than a square, box-like inclosure when seen from an eminence at a moderate distance. Of comrse there need be no hesitation when tlie heights are not traversed by any of the prineipal walks or rides; for on uneven surfices it is impossible to avoid all unpleasing effects from every point of the park. At the same time it should be ascertained that the expectation of shelter from the situations to which we hare alluded is not tallacious. Rising grounds sometimes cause a repercussion of tho aërial currents, or so direct their movements as to 
render the intermediate valleys as little protected as a more open and apparently less protected position.

And it is needful to remark that the beautiful or the picturesque are not the only considerations to be taken into account, in selecting a proper site for fruit and kitchen-gardens. These desirable properties are more than counterbalanced by the disadvantages arising from a cold exposure and damp soil, which unfailingly render the crops of fruit and vegetables of inferior quality. The site to be sought for, and to be found if possible, is one with a good soil, a dry subsoil, and a sunny exposure, sheltered suffieiently, but not shaded. The ground should be level, or rather, perhaps, with a slight declivity toward the soutl. A northern exposure should be avoided: we would prefer even a considerable declivity to the south, though steep inclinations require more labor in cultivation than level surfaces.

A certain amount of shelter is indispensable to a good garden; and where this is not to be had, sites in other respects favorable are to be avoided. Some natural protection should be sought for, particularly when the place is destitute of old plantations. Shelter may certainly be obtained by judicious planting; but it is to be remembered that in exposed situations fifteen or twenty years may elapse before it becomes effective.

The Dratnage of a garden should be perfect-certainly at least not inferior to that thorough draining now employed for agricultural purposes. To most horticultural operations a completely drained and therefore warm soil is essential: damp ground yields only inferior vegetables, and supports only diseased, 
short-lived, and unproductive trees, bearing ill-favored fruit-a state of matters, however, not unfrequently seen in gardens of considerable pretensions, though surrounded by well-drained fields. Why such evident negligence should be permitted or overlooked, it is hard to say.

Note.-In relation to thorough drainage of spongy, springy, or dishing lands, Americans have almost every thing to learm. The tile-draining system of Great Britain has lately been introdnced into America with marker effect. Agricultural lands have been donbled in their productive value by the simple and comparatively cheap process of draining; and no garden, orchard, or ornamental grounds requiring it, can give satisfaction so long as drainage is necessary. We commend this subject particularly to all those whose grounds are not entirely free from superabundant moisture.-ED.

SorL.-It has been said above that the soil of a garden should be naturally good; perhaps, howerer, this property, which is by no means unimportant, should cre way when necessary to the considerations formerly adverted to, and to a desirable position in the park. There are few situations in which good soils can not be formed by artificial means; but there are some subsoils which can not be sufficiently dried and warmed by any amount of drainage; and there are sometimes good soils whose accompanying disadvantages in site and position can scarcely be remedied or modified by any expedient. Gardens on such untractable sites may be seen on the level grounds by the sides of lakes or streams. In these the soil may be excellent, while the subsoil is incurably damp: 
There the late spring and early autumn frosts prevail to a greater extent than on the adjacent high grounds, and these may baffle the best directed efforts of the gardener. The crops of early regetalles are retarded, the blossom of the fruit-trees is often destroyed, or, when it escapes, it is followed by deformed and illripened fruit. The proprietor of a garden, formed at considerable expense, is left with a deficient supply, and is mortified by the comparative abundance enjoyed by his neighbors, who have been more fortunate in the choice of a site. A good, sound, loamy soil is the most useful for general purposes. But if an artificial soil is to be formed, it will be found useful to have some variety - one compartment, for example, being composed of light sandy earth, and another of strong loam. Peaty and clayey soils are objectionable: the former are feeble and cold; the latter, though productive, are late, with a damp, uncomfortable look, and require additional labor.

Forar.-The form of the kitchen-garden, and the consequent arrangement of the walls which surround it, are nsually determined by the nature of the ground, and by the extent of space inclosed. On all surfaces not deviating much from a level, the favorite configuration is a rectangular one, either a square or a parallelogram; and in these forms the grounds can be laid ont to the greatest advantage, with fewer walks, and with compartments most suitable to the culture of regetables and the arrangement of fruit-trees. A number of other forms have been occasionally adopted, but without apparent benefit. For example, in order to diminish the expense incurred in erecting the walls, some have chosen the form of an octagon, or other 
polygon more nearly approaching the circle, it being well known that the circle contains the greatest space within the smallest perimeter. Among practical men there is an impression, which is probably well founded, that walls of a circular, or polygonal configuration are more frequently and injuriously swept along by winds than those of the ordinary rectangular forms. Every ardent horticulturist wishes to have as much wall as possible with a southern aspect. Indeed, snch is the superiurity of climate on these walls, that it is somewhat surprising that they are not more frequently multiplied by being built in the interior of gardens, running from east to west, as in the peachgardens in France. The massire, and therefore expensive, style in which garden walls are commonly built in this comntry probably accounts for the neglect of so obvious an adrantage. We would nevertheless recommend such intersectional walls of moderate height and slight construction to those who liave a taste for fine fruit, and who are forming gardens on surfaces with a considerable slope towarl the sontin.

The additional warmth afforded by walls is a matter of great importance, and is therefore generally taken into account, and is allowed due weight in regulating the form of gardens. The finer kinds of fruit-trees grown in the open air, and cultivated in the United Kinglom, require all the protection and aid which walls afford to trees trained on them, in order properly to mature their fruit. The position of walls has a material effect on the climate: that is the best in which the line of the wall is at right angles to the meridian of the place, giving one of the sides a directly south aspect, though, to suit the ground, one a few degrees 
east or west may be adopted without any appreciable difference in the warmth. The walls running south and north, or parallel to the meridian, and facing to the east and west, afford secondary climates; and walls in the intermediate directions have climates varying in excellence according as they approach to or diverge from the south. In the southerm parts of the kingdom, where the climate is fine, this subject is of less importance than in the middle and northern districts. Even the difference of a single degree of latitude has a noticeable effect. In the neighborhood of London, in latitude $51 \mathrm{deg}$. $30 \mathrm{~min}$., peaches ripen on a south-east aspect; while at Edinburgh, latitude 56 deg., they require a south wall, a fine season, and other frorable circumstances, to arrive at maturity. When a large extent of wall, witl a first-rate climate, is wanted, a parallelogram, with its longer sides facing toward the south, should be adopted, and the southern aspect of the south wall should be made available by means of a piece of inclosed ground in fiont of it: when this is not an object of much consequence, a square, or some other more varied form, may be selected.

Note-The American reader will perceive that walls, as here discussed, are but of minor importance in the more propitious climate which he enjoys for garden cultivation, as compared with that of Great Britain.-En.

THE WALLs.-The height of the walls should have some proportion to the size of the garden. They may vary from eight to sixteen feet: below or abore tliese heights they are neither convenient nor useful. For these walls, well-made and well-burnt bricks are certainly the best materials, being most kindly to the 
growth of trees, and affording the greatest facilities for training them. We have often, however, had walls erected in whole or in great part of stones; and when the stones were good, and kept down to a proper size, we have found the walls little inferior to those composed of brick. In good gardens a considerable por. tion of the best walls shonld be constructed with flues and furnaces, so that they may be artificially heated in spring and autumn - in spring to protect the blossom, and in autumn to aid in maturing the fruit, and what is perhaps of equal importance, to ripen the fruitbearing wood for the following year. We may add, though the remark perhaps belongs to practical horticulture, that in autumn artificialseat is often applied only during the night. This is improper; for light, a main agent in perfecting vegetable life, is then absent. When the fire-heat is employed during the day, it cooperates with the solar heat and light in the elaboration of the juices of the fruit and foliage, and its action may be equivalent to the reduction of several degrees from the latitude of the place. Good flues, with proper furnaces attached, have been found to be superior to hot-water pipes as means of heating walls. These pipes, when placed within internal cavities, unless they be very numerous, and their sides extremely thin, emit a heat too feeble to produce an appreciable effect on a large surface of wall.

Note.-The above paragraph is of no account in our American climate.-ED.

The Frutt Garden.-This department is so fre. quently and so properly united to the kitchen-garden that it scarcely requires a separate notice. The site and soil which suit the one will generally be found 
appropriate to the other. When orchards are planted apart from the litchen-gardens, [and tley should be so planted-apart from the kitchen-gerdens-ED.] a warm, dry, and sheliered locality shoril! be selected for them. In the more northern or rnidland districts, the outer sloping banks - but not the level holms - on the sides of rivers, are found to be singularly propitions to the growth of hardy fruit-trees. Orchards, when not very artificially planted, and when furnished with proper accompaniments, may be made to harmonize well with the general scenery of the park and pleasure-grounds.

Note.-Still, orchards are better by themselves, in their own proper inclosures.-ED.

The Forcing-garden.- Fruit and regetables are said to beforced when their growth is accelerated and their maturity perfected by means of glass and artificial heat. The forcing-garden, then, requires a number of glazed houses or other structures of more or less complicated construction. It is usually mixed up with the kitchen-garden, or what is better, parly attached to it in a separate compartment. The vineries, peachhonses, pine-stoves, and occasionally a green-house, are commonly placed on the sonth side of the north wall of the kitchen-garden, while the furnates, sheds, and other necessary offices occupy the north side of the same wall. In such cases, when the nature of the ground permits, the pine-pits, melon-pits, and other minor forcing structures, should be arranged in an inclosed space behind the abore, but at such a distance as to prevent their being shaded during winter by the buildings in front: This is perhaps the best arrangement, as it keeps the whole forcing-garden together, 
and enables the work to be more speedily carried on. Where it canuot be so arranged, it should be formed at one end or side of the kitchen-garden, in the position most fitted to facilitate the various necessary operations.

A general range of forcing-houses may be formed so as to have an imposing and ornamental effect; but when these are placed in the kitchen-garden, the latter must be so arranged as in some degree to correspond with them. When they are above the character of mere forcing-houses, and particularly when plant-houses form a portion of the range, they should be erected, not in the kitchen-garden, but in some neighboring portion of the ornamental grounds, such as a small flower-garden or in a section of the lawns. In this way a good transitionary link can be established between the kitchen-gardens and the pleasure-grounds. Care, however, must be taken to prevent the smoking chimneys from becoming offensirely visible, and to screen and inclose the necessary sheds and roads leading to them - objects frequently not easy to be secured in detached situations. Our purpose in this volume does not lead us to enter into detailed statements in regard to the erection of forcing or plant-houses, and to the methods of heating them. On these subjects we may refer our readers for information to any of the recent worlis which treat professedly on horticulture, such as Loudon's "Encyclopædia of Gardening," or to the article on Horticulture in the "Encyclopædia Britannica," or to the reprint of that article in "Neill's Gardening." The latter, which we are permitted by the publishers to say we aided in getting up, particularly the department now referred to, will be found 
useful by gentlemen acquiring first notions on the subject, as it is almost wholly free from technical details. Since these works were published, the system of roofing glass-honses by small glass ridges and furrows has been greatly improved by its inventor, Sir Joseph Paxton, and employed in the construction of the Crystal Palace, which, but for this method of roofing, might never have existed in its universally admired form. In our practice in this department of gardening, we have found the ridged roof to be admirably adapted to green-houses, conservatories, and even to the minor structures employed for the rearing of plants.

Note.-The "span roof" has been adopted in the United States within the last five years, and in practice, generally approved. Plant, or tree-houses in this style have a showy effect in pleasure-grounds, and where not interrupted by the shade of adjacent structures or trees, are, as distinct buildings, perhaps the best and most economical. For graperies they possess some advantages over the lean-to method of roofing, admitting the sun from rising to setting, and a greater degree of light than the others will attract.- $\mathrm{E}_{D}$. 


\section{CH A P T P X.}

PUBLIC PARKS AND GARDETS.

SECT. I. The Public Park-Site of the Public Park-Laying out of Public Parks - Educational Institutions.

SECr. II. Street Gardens.

Secr. III. Botanic Gardens - Special Purposes of Botanic Gardens Botanical Museum - Laying out of the Botanic Gardens.

SECT. IV. Gardens belonging to Horticultural and Zoological Societies Gardens of Horticultural Societies - Laying out of Horticultural Gardens - Horticnltural Museum - Zoological Gardens.

\section{Sect. I. - The Peblic Park.}

Peblic Parks are large inclosed pieces of ground in the vicinity of cities or towns, partly covered with trees and shrubs, partly consisting of pastures, lawns, and pleasure-grounds, with their nsual decorations, and provided with other means and appliances for the recreation and amusement of the inhabitants. We adopt the common title, Public Park, though some recent examples scem to partake as much of the character of the pleasure-ground as of the park. Their ntility and importance in social and sanitary points of view are only beginning to be adequately appreciated; and much of the progress which, in these respects, has been made is due to the exertions of the late Mr. Loudon, who, in various articles in the "Gardeners' Magazine," was the first to draw public attention to their value. In these papers, conceived in a most 
benevolent spirit, and expressed with much earnestness of manner, the departed artist labored to show that, in the public park, the pale mechanic and the exhausted factory operative might inhale the freshening breeze and some portion of recovered health; the busy shopkeeper and the more speculative merchant might enjoy relaxation and bracing exercise in temporary seclusion from their toils and cares; and that the family troop, the children with their nurses, or the sportive juveniles in the company of their staid seniors might take their walk or spend their play-time apart from the bustle of the streets, and secure from the accidents to which, in crowded thoroughfares, they arc necessarily exposed. Witlout doubt, it is also good for the mental health of those who are habituated to the wear and tear of the busy haunts of men to be bronght face to face with the tranquilizing as well as suggestive works of God in the world of nature. It is well that all who are capableand we can not tcll how many these may be - should have an opportunity to "reap the harvest of a quiet eye" in scenes which, if not invested with all the wildness of the rural districts, have yet as much of the treasures of vegetable forms and co!or's as are accossible to the inhabitants of cities without a considerable expense of time and labor. Certainly the resort to such places of recreation is very great. Looking to the metropolitan parks of the United Kingdom, we find all classes of the community, the day-tasked oflicial, the night-worn senator, the slaves of business, and the votaries of fashion, even royalty itself, all availing themselves of the air and exercise, and scenes of gayety and opportunities of social intercourse and enjoyment which these much frequented places afiord. Nor is it 
to be overlooked that the public parks, and eren the smaller gardens in squn:er mil streets, are fitted, if skillfully distributed, to !eseen the ecindensation of our large cities, to extend their crowding buildings over a wider surfice, to rarefy the thick lalack clouds of smoke which rise from them, a:m? so to incrense their light, and to provide a larere stuply of sainirions air for all the inhabitants. In siost. elcy are, as it were, the lungs of cities and tewris; and as snch they are breathing-places to thonsand: iwlio n:ly i:ever wander from the streets within their actual precincts.

Affording such advantages in the way of health and comfort, it is rather singular that but few public parks have been formed, and that most of them have been of such recent introduction. Men are naturally gregarious animals. In the old times of warfare and bloodshed, they lept close together for the sake of mutual defense. It is remarkable low small an area some of the ancient fortified towns ocenpied. Probably the original instinct of crowing together would hare continued to prevail, but for the example presented by those parks attached to the metropolitan cities of Great Britain, to which we hare already alluded. Much penetration was not required, to perceire that such wide spaces as IIyde Park, St. James' Park, Phœnix Park, Dublin, the Queen's Park, Edin. burgh, especially when thrown open by the munifi. cence of successive sovereigns, were boons of the lighest value to the adjacent communities. It is only surprising that a discerning public was so slow to discover that similar advantages were to be enjoyed elsewhere.

Doubtless there were some considerable obstacles in 10 
the way. Supposing, what was probably but seldom the case, that the utility and desirableness of public parks were clearly appreciated, it required no small amount of publie spirit, and no ineonsiderable measure of wealth and inflnenee, to eneounter and sur. mount the palpable difficult:es that stocd in the way. The high marketable value vil lands in the vicinity of large towns, angerly taken up for the purposes of gardening or building, might render their purchase almost or altogether an impossibility to the local corporations. Then, too, the land might be dearest at the very point where it was most desirable that the park should be placed. Besides, the extremo division of property often prevailing in snch loealities sometimes renders combined action for public objects next to hopeless. The greater is the honor due to the communities, such as that of Manchester, that have had enterprise enough to undertake, and skill and vigor enough to carry through, the works which, in this career of improvement, they have actmally aceomplished.

The Site of tile Public Park, viewerl as calenlated to promote the health of the community, should be as near the city or town as possible; and, indeed, its beneficial influence would be augmented were it partially to intersect the area occupied by the streets and other buildings. In such a position the park would be of easy access to the inhabitants, and would form a wide breathing-space, or lungs, as already said, preventing that dense and unlealthy crowding of streets and lanes which are rapidly forming in compact masses, with manifest injury to the sanitary condition of some of the principal manufacturing towns in the United Kingdom. Such is the importance 
of the subject, that it well deserves the attention recently paid to it by govermment. Certainly it wonld be no misappropriation of the public funds, were a commission authorized to purchase, in the suburbs of many large towns, land sufficient for the formation of a park: thus doing what might not be within the power of the local corporations; and, putting sanitary considerations out of the question, we do not believe that, in most cases, the concern would be a losing one; for the grount-rents of the houses contignous to the park would be higher, and the sites would be more readily occupied by the wealthy citizens than elsewhere in the neighborlood. We have seen estates, in the suburbs of large cities, which would probably, by this time, liave been covered with streets, had the owners given, with a wise and self-rewarding liberality, some thirty or forty acres to form a public park - a measure which would have speedily indennified them for the apparent loss, by the increase of rental received from the remainder of the lands. By forming parks round London, recent governments have conferred a great boon on the inliabitants of the metropolis. Perhaps, however, they might have proceeded on more judicious principles. If, instead of enlarging the parks to the extent of 150 to 270 acres, and placing them at considerable distances, they had confined them to 80 or 100 acres, at one-half the distance, and had multiplied them proportionally, they would have easily procured a sufficient quantity of ground nearer and more accessible to all classes of the inhabitants.

Laying-out of Peblic Parks.-The designing of these grounds, and the erection of the works, must 
proceed on the principles already indicated in this work, in reference to prirate parks and pleasuregrounds. There are, however, some differences which the designer must take into account. For example, the furmer are intended for public, the latter for private use. In an ordinary country residence, the mansion-house and its appurtenances form the center of attraction, and the point to which all others are referred; but such a point of eentralizing interest is wanting in the public park. And as the style of decoration in towns is generally more profuse and elaborate than in rural districts, it may be conceded that the city park should be more ornate, and may contain a greater multiplicity of showy objects, than would be altogether suitable in the country. It may be presumed, too, that the arerage taste of those who frequent suburban parks (we refer more particularly to the working classes) is not highly cultivated and severe; and consequently, the expression of these localities need not be so quiet, nor the style so strictly in harmony with the character of the ground, as may be deemed necessary in the seclnded retreats of men of much cultication and refinement. The public park should be gay, though not glaring or obtrusively showy. Accordingly, we would admit into it a variety of terraces, statues, monuments, and water, in all its forms of fountain, pond, and lake, wherever these can be introduced without violent and manifest incongruity.

Speaking generally, when the park is small-say from twenty to forty acres - we would have it to partake mostly of the character of pleasure-grounds; that is, it should chiefly be occupied with lawns, walks, shrubberies, and moderate groups of trees. When 
upward of sixty acres, these grounds should be parlis in the proper sense of the word, furnished with a few inclosures for pasture, broad and well-formed walks or drives intersecting and sweeping round the whole, large masses of trees, approaching at times to the character of woods, together with a reserve of some acres, by way of pleasure-grounds or dressed grounds, attached to the parls.

The buildings essentially necessary to a public park are few; in short, a honse for the superintendent, and a cottage or two for the gate-keepers, may suffice; but where flower-gardening is ineluded in the operations, as it ought to be at least to a moderate extent, we should be inclined to insist on the addition of a small green-house, to be employed in the propagation, and in the protection during winter, of those tender ornamental plants which are bedded out in summer. $\mathrm{We}$ have already noted the defect in this kind of park, arising from the absence of a mansion-house, and we should recomnend the supplying of this want by the erection in it of any suitable public buildings. Nothing would he more appropriate, for example, than a picture-gallery. Statues, too, erected to distinguislied citizens, or other illustrious charaeters, wonld find there a more suitable station, and a more comfortable lrome, than in the crowded thoroughfares of streets and squares, where their uncovered heads, and their limbs scantily draped in classic costume, are alternately soiled by dust and soot, amid all the changes of rain and sunshine, of snow and thaw. Museums containing objects of natural history, and collections of antiquities, are also desirable and instructive accompaniments of these places of publie resort. The 
museum in the Peel Park, at Manchester, is not the least interesting part of it. Separate gymnasiums should be constructed for the youth of both sexes, (it is always well to give loiterers sometling to do,) and bowling-greens should be formed for persons of more advanced years.

We have already said that water should be employed as an ornament in public parks, in all suitable localities; that is, where the town is not built on such a craggy or twisted surface as to preclude the possibility of finding a sufficient extent of level space, or where the vicinity of the sea, or a broad river, does not throw an air of ridicule over the mimic efforts of the designer. Most of the inland towns and cities of the empire are so situated as to render artificial sheets of water desirable; and accordingly, they are to be found, we believe, in all the public parks which have been recently constructed. It must be eonfessed, however, that the very flatness of the localities often renders the successful execution of such works a matter of great difficulty. It would be an easy, but a somewhat invidious task, to point out eertain signal failures in this department of designing. Nearly all the specimens of this kind of waterworks which we have had an opportunity of inspecting, are deficient in breadth of effect; some of them are little better than wide canals, and some are grotesque ponds, which the artist seems to have eopied from his own hand, with the fingers spread out, as if in astonishment at his own ingenuity. The taste is little exigeant that is satisfied with such things. The small lakes in the Royal Botanie Gardens, Regent's Park, by Mr. Marnoch, and those in tl:e Queen's Park, Liverpool, by Sir Joseph 
Paxton, may be cited as artificial pieces of water with an inartificial look. It is most needfui that the designer, before he attempts this sort of work, shonld make himself fimiliar with the ontlines and the slopes in the banks of natural lakes, and that he should keep distinetly in view the ideas which he has thus aequired. Insteal of griving any further directions in detail, we beg to refer to our chapter on Water.

The wallis and drives in the public park slonld be broad, well-made at first, and kept permanently smooth and dry; otherwise their edgings will be much trodden down, and their whole appearance will be mean and slovenly.

With respect to the grouping and massing of trees and shrubs in the public park, we may refer to a previons part of the volume, where we have treated of the park generally, as it is evident that the same principles must come into operation in both cases. We would strongly recommend, howerer, that in planting the public park, part of its trees and shrubs should be so arrangerl as to combine instruction with beanty of effect. This object night Le easily attained by the formation of arboretums of nore or less extent, as also by making coliections of stich hardy plants as are used for manufacturing and agricultural purposes. Of course, such arrangements of plants and trees sinouid be furnished with labels exhibiting the scientific and popular names of the species, and any other informa. tion relative to their uses and native habitats that conld be condensed into a small space. It is almost incredible what ignoranee on these points exists among the inhalitants of large citice, who probalily would know an oak to be a tree as they would know a crow. 
to be a bird, witile they conld tell little or nothing more about either. It is to be regretted that, with the exception of St. James' Park and Kcosington Gardens, all the public parks around London and Manchester are totally deficient in this simple and obvions means of instruction. Of course we do not wish that every bush and tree within the inclosure shonld be labeled; we only propose that some definite portion of the trees, shrubs, and other plants, should be arranged and named for this special purpose. Besides the information actually conveyed, and the inquiries as to uses suggester, such arrangements would exhibit, in an interesting manner, the wonderful adaptation of $\mathrm{om}^{\circ}$ climate for the growth of plants from the milder and colder regions of the globe. They would display in one group the magnificent cedars of Lebanon, of Atlas, and of the Himalayas, together with the firs of Siberia and the Pyrenees, of Scotland and Califurnia, of the Mediterranean and the Oregon, of Norway and Nepal. In a second, they wonld show us the broad oak of Old England, the cut-leaved oak of Turkey, the evergreen oak of Spain, and the red oak of America, with the sycamore of Britain and the sugar-maple of Canada. In a third, we might find the Arbutus of Ireland, the Andrachne of the Levant, the Phitlyrea of Italy, the lilacs of Persia and China, and the Aucuba of Japan. Manifold are the interesting and instructive combinations that might be formed; and they could all be effected at an expense very little beyond that which is necessarily incurred in the plant. ing of ordinary trees and shrubs.

Note.-Our author, on this important subject, talks 
with the strong sense and good taste of a thorough Englishman. If land were as plenty and cheep in America as it is in. England, Americans might, perhaps, talk of public parks, also! But whether they would have them, is another matter. A very pretty discussion might be got up, touching the utility of public parks, in a country so utilitarian as ours pro. fesses to be; and much might be said on both sides. At all erents, we do not propose to enter the lists as a debater. Yet, in the small specimens of inclased grounds which exist in some of our principal cities, and dignified with the name of "Parks," we can not but imagine that if, instead of acres by tens, so appropriated, they had been by hundreds, cities containing them would be all the better for it.

In sober carnest: it is a disgrace, in point of public taste, that our cities and large towns show no specimens of extended park and pleasure-grounds for the multitude. For the lack of these, and the consequent lack of respect to the character of trees, there is hardly a place of public resort in the United States, in which the trees standing abont them are not whittled and scarred by the impudent initials cut into their bark by the risitors; and thought, at the time, to be exceedingly smart, by the perpetriators.-ED.

Endcatiosal Iristitutions.-It may not be much cut of place, to add a few remarks in regard to the somewhat cognate subject of gardens or pleasuregrounds attached to some great educational institutions; cognate, at least, in this respect, that these grounds, as well as the public park, might be made the means of coonmunicating important instruction. It should seem, 10 * 
indeed, that they would promise more, in this respect, than places set apart for the common resort of the citizens; and yet this promise has been most strangely unfulfilled and neglected. Not to speal of universities, some of which have their botanic gardens, there are, for example, around Edinburgh, six foundation schools, or lospitals as they are there called, in which children of certain classes of the community are boarded and educated till they are of suitable age to go into trades or professions. Some of these institutions occupy magnificent buildings, and have almost princely revennes; all of them are well endowed; and yet, while they are surrounded by grounds more or less tolerably laid out, not one of them possesses a named collection of plants; nor, so far as we know, is any regular course of instruction in regard to natural objects maintained within them. We can not think that this state of things, subsisting under the direction of numerous well-informed and intelligent men, is very much to the credit of the science and the enterprise of Modern Athens.

We would deem it lighly advisable to attach a garden of two or three acres to the normal schools provided by gorernment for the improvement of teaching. These, under proper management, would enable the pupil-teachers to carry back to their native homes or future places of labor, a correct nomenclature of plants and much other useful information respecting them, but little known in secluded districts. In reference to these matters, the progress made in Ireland is much in advance of that on this side of the clamnel. The agricultural seminaries at Glasnevin and Temple- 
moile have considerable collections of trees, shrubs, and plants attached to them.*

Note.-Although the subject of ornamental grounds attached to educational institutions has arrested both the attention and pens of some of our most accomplished men, every one possessed of true taste must lament the want of attention hitherto paid to that department of education, in Anerica; for it should be a department of our public edueation, as much as the langnages, or the sciences. Indeed, the founders of most of our large institutions of learning, whether through the state governments, public associations, corporations, or individual munificence, have, in the liberality of their endowments, and ample appropriations of grounds, intended it - theoretically, at least; but in most cases, the intention has been miscrably neglected in the carrying out. Every boy-every student-no matter what his proposed occupation or profession in life, should, as a part of lis education, be tanght the principles of regetable plyysiology, and how to plant a tree, and tend it afterward. It is scarce worth while to occupy these pages with a homily on the importance of embellisling, by the planting of trees, grounds devoted to seats of learning - even the district school: a thing so entirely obvious, on a thought of the subject; yet it is a truth, that in no country professing to be civilized, is less attention paid to this than in the United States. It is a barbarism, and for its

\footnotetext{
- In 1840, we laid ont an arboretun and miniature botanic garden, about twelro acros in extent, around Gwynn's Institution, Iondopdenry - an institution for the maintenance and education of orphan clildren. There is also a small farm attached, in which, as well as in the grounde, many of the children are trainel to rura! labor, and so fitted to become useful members of society. The enlightened liberality which his uniformly claracterized this institution has rendered it a blessing to the poor, which is highly and deservedly appreciated by all classes in the maiden city.
} 
continuance there is no possible excuse. We may profitably take lessons of improvement from the people of countries whom we affect to hold in little regard; but who are, in this subject at least, a great way onr superiors.-ED.

\section{Sect. II.-STreet Gardens.}

Allied, in some respects, to public parks, are the gardens which are formed in squares, and other open places in towns, and in front of streets. These grounds, however humble they may seem, are very beneficial to the population around them; and they onght, therefore, to enter more into our street arrangements than they do at present. They serve to spread the inhabitants of large cities over a wider surfaee, they inerease the purity of the air, and act, in short, as miniature parks. The square and the street with gardens in fiont, julging from their paucity in most towns, do not seem to be so popular places of residenee as they ought to be, and we ean not altogether wonder that this should be the ease. Mrost of them are extremely ugly, particularly when viewed from the street. The objects there presented to an observer are an iron railing of affected finery, with a line of trees hanging over it, dirty, rickety shrubs below them, patehes of red earth partially corered with straws; in short, a whole exhibiting a miserable aspect of squalor and discomfort. As to the plan, the dominant type invariably requires a belt of trees and shrubs around the inside of the railing, and a circle in the center'; the latter figure, however, occasionally giving place to a statue or a monument. If the belt is varied by a few projections 
or clumps in the inside, its external continuity is nevertheless rigidly maintained; and the usual fecling communicated to you, in passing round a square, is that you are walking in the front of a row of houses, but at the back of a garden. The internal arrangements are often little superior to the external, and often they are worst where most inight liave been expected. We have seen, for example, a frill of shrubs added to the original belt, and two dull outlines produced instead of one. We have seen parallel terraces which are not parallel in their levels, and curtailed, moreover, of their fair proportions by an oblique walk slanting across the base. With a varied proprietary and hundreds of overlooking windows, the ruling idea in the laying-ont of street gardens seems to be their seclusion from the vulgar eyes of passengers on the parement. The inhabitants of such places not unfrequently complain of their exclusion from the parks and gardens of comtry gentlemen, and this often in entire oblivion of their own equally illiberal and more inconsistent exclusiveness in regard to their city paradises. But if street gardens are inferior in design, they are scarcely less so in their management. A directory of worthy citizens, with a jobbing gardener as their executive, often perpetrate great barbarities on the unfortunate slrulus and trees growing under their régime. What with the manifest errors in the laying-out of the grounds, the mutilations inflicted on trees and shrubs in palpable ignorance or contempt of arboreal beauty, the inevitably injurions effects of dust and smokethe whole influences, natural and artificial, resulting in a dainty but puny me-in-urbishness, as it has been expressirely called, we have sometimes been tempted 
to wish that squares were empty places, or even the sites of bustling markets, rather than that they should contiuue in that paltry condition in which most of them actually exist.

And yet, such would be a consummation greatly to be deplored. People, while planning a section of a town or city, will think of a square with its hoped-for greenery a hundred times sooner than of a place, or open pared area. Dismiss the conception of a square, and a block of dense parallel streets will certainly come in its stead. Probably the nost imperfect squaregarden is more propitious to health than a paved area is, particularly in the heats of summer. Besides, the garden is a place of refuge and of play to the children and the juvenile people of our cities. Why, then, will proprietors, after they have expended many liundred pounds on parapet walls and iron railing, not go to the trifling additional expense of engaging the ser vices of a qualified professional man? The square. garden is surely not an insoluble problem, though it has its difficulties everywhere; and when it is to be formed on a dead level, and still more on a slightlytwisted surfice, its natural felicities are not considerable. A practiced eye will at least avoid conspicuous blunders. An ordinary courage might suffice to make a few gaps in the encircling belt. And we must add, that after a garden of any kind has been formed at considerable cost, it is a self-defranding economy that grudges or withholds the necessary naintenance. To afford unalloyed pleasure, all gardens must be "trim," to use the epithet of Milton; and this is especially true of the square or street-garden; which, as we liave seen, is peculiarly exposed, from its situation, to be 
soiled and tarnished. We should be disposed to recommend that, in such gardens, a plain, quiet style of beanty should be aimed at; but that it should be elaborated, and kept up with a rigid and pervading neatuess.

Note-Wothing could be better said, on such a subject.-ED.

\section{Sect. III.-Botanic Gardens.}

Botanic gardens, both in their present dedication to scientific purposes, and in the economical uses to which they are probably destined to be applied, may be regarded as among the most important public gardens in this country. They are intended, primarily, to contain general collections of plants, both native and exotic, both hardy and requiring protection, and particularly those species which, from their possessing moderate ornamental qualities, are not likely to be cultivated in common gardens. In the neighborhood of medical schools, they are of great utility, as presenting systematic arrangements, in a living state, of the plants employed in materia medica. They are also likely to beeome highly beneficial by forming collections of regetable substances adapted for food, and used in the arts and manufactures, though this is a purpose to which they are only beginning to be applied. On these grounds, botanic gardens can meet the demands of the most rigid utilitarian. To persons of a scientific turn of mind, and of refined understanding, they possess a rery high interest. They have done much to feed with oil the lamp of botany, 
which, during the last century, has burned so brightly, and has shed so brilliant light on the science of method, as applicable to the natural sciences in general. They have stimulated the search for plants abroad, and promoted their diffusion at home; and they have facilitated, in a greater or less degree, the inspection, and so have extended the knowledge, of the vegetable system of our globe, the individual members of which the wise and beneficent Creator has endowed with constitutional peculiarities suited to every habitable region of the earth, and has fitted, either directly or indirectly, to house, clothe, and feed the infinite variety of animal life to be found on its surface.

To regard botanic gardens merely as receptacles for objects which are the materials of botanical classification, is to place them much below their proper sphere, and to make them representatives of human systems, rather than of that vast order of vegetable being established by the great Creator. How far many of these institutions have risen above their lower, and ascended toward their higher and more legitimate position, must be left to be ascertained by actual inspection. Doubtless, botanic gardens have considerable difficulties to contend with, and, from a variety of circumstances, are occasionally liable to stagnate. They require abundant liberality on the part of the patrons, wisdom and science on that of the directors, and great diligence, some versatility and activity of mincl, and entire consecration of time and attention in the curators. Perhaps it is not often that all these requisites are found in combination, and the want of one or other of them may partly account for the inferiority in those gardens whick occasionally exists. It is not our 
design, however, to speak disparagingly of the botanic gardens of the United Kingdom; many of them are ably and admirahly managed; of these we do not name any, because we cannot enumerate all, and a particular specification of some might seem invidious to the others. We can not help directing the attention of the reader to the great exotic nurseries near our metropolitan cities, and in other parts of the country; which, thongh conducted on commercial principles, are substantially botanic gardens, and are not the least remarkable instances of the union of capital, enterprise, skill, and industry that are to be found in the present day.

Special Perposes of Botanic Gardens.-In the preceding remarks, it is implied that botanic gardens are intended to be the means of public instruction; we may now notice some of the particular expedients for the accomplishment of this desirable end.

All botanic gardens are, or ought to be, furnished with systematic arrangements of herbaceous plants a minor one, according to the Linnæau, and a more extensire one on some one of the natural systems. As a pendant to these, there ought to be a general arboretum, in which all ligneons or wooded plants, which, as they can not be conveniently grouped in the herbaceous arrangements, may be put into scientific combination; and unquestionably, this is best done on the principles of the natural orders and families. Besides, there should be a separate arrangement of medical plants. To give specific directions on these points, does not fall within our present design. We content ourselves, therefore, with merely alluding to them; and we proceed to indicate some other objects which 
it is desirable should be kept in view more fully than heretofore in the formation of this species of garden.

Territorial arrangements of plants have been recommended, and, we humbly think, have received too little attention; for, being skillfully executed, they would possess a high degree of interest. There are difficulties, it is true, in carrying ont the territorial principle, particularly in regard to those exotics which require protection and artificial heat. Still, much might be done with the natives of the temperate and frigid zones, to exhibit the vegetation of particular kingdoms. At least three of the quarters of the globe-Europe, Asia, and America-conld be adequately represented; and subordinate sections, if necessary, might be made to include the plants of the more important countries, or ranges of continent embraced in the main divisions. For example, we might have a British Flora, a French and German Flora, a Mediterranean, a Russian and Siberian, a North American Flora, and various others. Undoubtedly, one of the most curious things in our flower-gardens is to see natives of the Alps and the Himalayas, of Oregon and of the Cape of Good Hope, all growing peacefully and lovingly together; but in consequence of this promiscuous planting, the facts of botanical geograply are at once lost sight of, and very often completely forgotten. It is admitted that it would be difficult, or rather expensive and laborious, to carry ont the territorial system to a great extent; yet it might be within the compass of attainable effort to adopt the principle in part. We should like to see a real American garden-that is, one containing only American plants, and not the mixed affair which goes generally under 
that name. There might at least be distinct gardens for the natural regetation of the United Kingdom, and of her principal colonies - those, namely, in North America, the Cape, Anstralia, New Zealand, and the mountainous regions of India. It is not proposed that every plant which is to be found within the limits of any country should be included in these separate arrangements; but it seems possible, by the selection of characteristic species, to give a fair representation of the regetable economy of the territory selected, and even to convey an expression of its external physiognomy. The space required for such purposes is not necessarily large, as the trees and shrubs which occupy most space might be kept small, there being other specimens of the same species, in the general collection, allowed to reach their natural development. Let any one go into a botanic garden, as commonly arranged at present, in order to acquire a knowledge of the regetation indigenous in any of the temperate regions of the world, and most likely he will have to trace, by the aid of books and other appliances, a botanical system scattered over the whole grounds before he can obtain even a glimpse of the object of his research. From the divisional gardens we are now recommending, persons about to travel might receive at once a general idea of the regetation they are likely to meet with in foreign countries; and all might learn with little trouble how much we are indebted to particular regions for the trees, shrubs, and plants that tenant our gardens. Certainly, the unbotanical public would find more attraction and instruction in these than in strictly scientific arrangements. We therefore strongly recommend them to the attention of our 
readers; admitting, at the same time, that they would require some increase of room and of expense; still, we think that there are several botanic gardens in Great Britain of extent and resources sufficient to admit of the experiment being tried with success.

All botanic gardens ought to possess a certain number of plant-houses, properly glazed, and supplied with heating apparatus. The more there are of these structures, the better; but their number and extent will depend on the amount of funds placed at the disposal of the institution. With cheapened glass, and other materials, it is to be hoped that they will become more numerons thar ever. These houses should have a special adaptation to the plants which are to grow in them. A botanic garien can scarcely be complete without a palm-house, a heath-house, an orchicleoushouse, besides stoves, green-houses, and propagationpits. It must always be remembered that the deepest interest awakened by this kind of garden comnects itself with the preservation and growth of those curious, and often singularly beantiful exotics, which are the natives of tropical or other varm climes.

The Botanicat. Musecar is now becoming a necessary and a most useful appendaye to the botanic garden. It is intended for the preservation of dried specimens of plants, seeds, samples of woods, and, in short, for every form of vegetable production that can be rendered permanent and kept in bulk. Every botanist is aware how important is the hortus :iccus to the authentication of species, and generally to the history of his science; there are, however, many other things besides formal specimens of plants, which are interesting and worthy of preservation. Properly arranged, 
and adequately completed, such muscums may be made to exhibit nearly the whole regetable system. In a former paragraph, we have recommended territorial arrangements of plants in the open ground; and we may here add, that we do not know any more interesting materials for the museum than well-arranged collections from various countries; not merely for displaying their native botany in its technical form, but also for exhibiting their regetable products reared by agriculture, and employed in domestic economy and the arts. Great Britain and its colonies, by themselves, might yield a most instructire exhibition of this kind. The museum in the Royal Gardens at Kew is the object of high patronage, and is rapidly increasing in magnitude and importance. A promising beginning has also been made at Edinburgh, which, it is to be hoped, will continue to make progress. In both. cases, howerer, much remains to be done before they can be said to hare accomplished their proper object. Meanwhile, they are worthy of all aid and approbation, as most useful and instructive parts of the institutions to which they belong. The territorial principle was well exemplified in the Great Exhibition of 1851.

Laying-out of the Botanic Garden.- The botanic garden, particularly when extensive, may be regarded as a combination of the pleasure-ground and the flowergarden - the former character predominating in the arboretuin, and the latter in the smaller and more ornamental flower-beds and borders. From the limited extent of space, and the variety of special adapta. tions to particular purposes, it is difficult to introduce much of the pictorial effect arising from the groups of trees and shrubs, interspersed with lawns, which is 
so prominent a feature in a well-laid-out pleasure. ground. Still, we think that much more of it might be secured than is commonly accomplished, or eren attempted in these gardens. At present, we can offer only a few hints ; and these rather in the way of pointing ont faults to be amended, than as a full exposition of a subject of some intricacy, and requiring a considerable amount of minute detail.

The site of the plant-houses is a matter of ruling importance, in the arrangement of the several parts of a botanic garden, as their position generally forms the starting-point from which the leading walks set out, and to which, indeed, every thing is related. These houses should not be allowed to occupy quite a central place in the garden, as they sometimes do; for, in that case, they leare only a narrow strip of ground behind them, and but a limited extent of free space in front. On level ground of a rectangular form, they should be toward either the north or south end-the former being the preferable, as affording greater facilities for forming back-courts and propagation-pits, and as giving greater freedom of access to carts bringing fuel and soils. By this means, most of the ornamental grounds may be kept in tiront of the houses, which will then form an elegant and appropriate back-ground. These houses are usually erected in ranges, and in that way they often produce an imposing effect; but we are sometimes disposed to question the propriety of this arrangement as a general rule, particularly when the plain lean-to form, common in forcing-gardens, is adopted; for it is evident that in that way they can receive light only from the roof, and the upright glass in front. We should prefer to lave them detached, 
singly or in pairs, for then they would be illuminated nearly all round. When we say detached, we do not mean scattered promiscuously throughout the garden-that would be a worse fault than the other, and would give rise to serions inconveniences in their management. They may be detached in groups, as leading objects of particular divisions of the garden. If ir general range is adopted, either from the limited extent of the garden, or from the grounds being favorable to the production of an imposing effect by the concentr:ation of the plant-houses in some particular spot, tile range, for example, might be thrown into divisions of lean-to or span-roofed bouses, of greater or less extent, placed at such distances as not to shade each other. These might be made to abut against a wall running east and west; and on this wall might be formed glazed corridors between the divisions communicating with the unain structures, and uniting the whole into one general range of ornamental glass. $\Lambda$ number of other arrangements, on similar principles, might be suggested; we merely hint at them, to show that those disjointed accumulations of plant-houses, set down apparently at hap-hazard, and not mnfrequently seen in ill-arranged nurseries, are not at all necessarily incident to the botanic garden, and ought therefore to be sedulonsly aroided. Perhaps some of the fanlts of this kind, to be found in better establishments, are to be ascribed to the circumstance that the brildings in question were after-thoughts.

The next error to which it is needful to advert is the too coinmon practice of planting mixed belts of trees along the exterior boundary walls. These are generally unnecessary; for in a botanic garden there is 
no need of that sechsion which is often desirable in the vilia. At the same time, the norderate vailing of the walls, and the securing of a proper degree of shelter, render the grouping and massing of trees and shrubs indispensable. This want can be nearly, if not completely, supplied by the skillful disposition of the arboretum. The arrangement of trees and shrubs should be such as to throw them into groups toward the external walls in some places, and toward the interior of the grounds in otbers; by this means a variety of open spaces, both in front of the walls and in the center, will be left for collections of plants, and for lawns to be decorated more or less with ornamental shrubs and showy anuual and perennial flowers. Lawns are seldon well managed in botanic gardens. They often exhibit the dotting system in its perfection, or are intersected by a multitude of paltry figures crowded with herbaceous plants. We are not disposed to recommend that these gardens should be laid out generally for lawn-scenery, properly so called; the space within them is too raluable to admit of that system as a whole; but the introduction of one or two lawns of moderate extent will relieve the preralent appearance of crowding, and will soften the effect of that multiplicity of figmring and dotting which, it must be owned, can not be wholly avoided.

Another difficulty in the botinic garden, which is often imperfectly overcome, and sometimes is not even attempted to be obviated, is to be found in the proper management of the collections of herbaceous plants. As these require a considerable space of ground, they are frequently overcrowded. Perhaps their most general effect is baldness and monotony - an effect not 
lessened by the color of the earth, and those ranks and files of painted tallies bearing the names, in winter more conspicnons than the plants themselves. When these collections are arringed in lines, with alleys of bare earth between them, the result is extreme baldness; and the plants seldom thrive, as the bare and generally weedless soil, reflecting the glare of summer light and lieat upon them, affords a lome as unlike the natural habitats of most as possible. When the lines are waved, with grass alleys intervening, the general effect is ameliorated, and in winter the ground has partially the semblance of a lawn. When the natural system of arrangement is adopted, the plants may be made to fall into groups; but few of the exanples of this kind of planting, which have come under our observation, are materially better than the wthers. They are usually planted in clumps in grass, but the figures are seldom good; the intervening spaces of grass are too narrow; and the plants too small to produce any of that lawn-like effect which we suppose is aimed at. We should deem it more advisable to alrange such collections in the form of parterres, compused of beds suited for the various tribes and genera, and intersected with grareled walks - a method which would economize the ground occupied, and facilitate inspection.

Note.-It is little creditable to American taste and enterprise, that although two botanic gardens have been, many years ago, liberally endowed - in the city of New York, and at Cambridge, Massachusetts, and possibly in other cities of the United States - they died out for want of care, and a failure to excite is sufficient interest in those who should have been 
sufficiently interested in them to secure their continuance. We are a great way behind Europe in this department, and it is to be hoped that our further neglect will not long remain a reproach to us.-ED.

Sect. IV.-Gardexs beloxging to Horticultural and Zoological Societies.

(1.) The Gardey of Horticultural Societies.-This species of garden is of more recent origin than those devoted to strictly botanical purposes. Soon after the rise of the horticultural societies, in the first decade of the present century, it was felt to be desirable that these institutions should possess pieces of gardenground, on which to perform such extended experiments as might be beyond the reach of private cultivators. Methods of culture recommended by professional men, or speculative amateurs, were to be repeated, and their general utility to be ascertained. Original observations were to be made. In all these and rarious other spheres of progress, the gardens of which we now propose to speak, as is universally adnitted, have conferred most important benefits on the practice of horticulture.

In botanic gardens many raluable and interesting plants can appear only as single specimens of the vegetable system, for in these the principle to be followed is the collection of species, and as the known species are now very numerous, many varieties and sub-varieties of great value in ornamental and economical points of view are necessarily excluded. In the horticultural garden, (to adopt the popular, but 
somewhat tautological name,) the principle which :-, or ought to be, adopted is selection. Certain plant:, whether species or varieties, but possessed of noticeable qualities, are chosen, and their culture is so cxtended and varied as at once to determine their practical value, and to illustrate and exemplify the best methods by which they may be produced in private establishments. In the botanic garden the predominating interest is the purely scientific; in the horticultural garden the chief aim is the useful, including in that term, however, the process of ornamental as well as economical gardening, and the application of scientific principles to the effecting of these ntilitarian results.

The gardens attached to horticultural societies have done much to promote the great advance recently made by this pleasing and useful art. The conductors of the splendid establishment belonging to the great metropolitan society-some of them men of high scientific attainments, all of them characterized by skill, perseverance, and devotedness to their favorite pursuits - have been particnlarly instrumental in forwarding the march of improvement. They have cstablished a correct nomenclature of fruits, which, from the prevalence of provincial names and other circumstances, had previously been in a state of great confusion. They have brought into general notice many good rarieties heretofore confined to particular localities. They have introduced many new and admirable sorts from abroad. The comparative value, too, of numerous fruits and culinary vegetables and flowers has been correctly appreciated, and those which were found worthless or indifferent have received the merited 
stamp of inferiority and rejection. Besides much work of this kind done effectually, the Horticultural Society of London has sent Botanical collectors to China, Mexico, and other imperfectly explored regions, and by their agency have introduced many plants, both useful and ornamental. In most of these objects the Caledonian Horticultural Society has zealonsly coöperated; and notwithstanding the less propitious climate, its distance from the center of government and commerce, and other difficulties with which it has had to contend, it has been eminently successful in the promotion of gardening in Scotland. Both of these societies, as well as others in the provinces, have contributed greatly to the diffusion of new and approved kinds of fruits, flowers, and vegetables, by the distribution of grafts, cuttings, and small specimen parcels of seeds. And we must not omit to notice the beneficial effects of the public cxhibitions of plants and fruits which have been promoted by horticultuial societies, and generally held in their gardens. The prizes given on these occasions have proved a great stimulus, not only to the perfecting of fine individual specimens, but also to the improvement of the general crops; and while they have elicited and rendered prominent many cultivators of distinguished talent, they have been the means of establishing a standard of excellence in reference to horticultural productions which would have been considered visionary forty years ago. In many parts of the country every considerable village and little town has its own flower and fruit shows; and when it is considered how much harmless and healthful enjoyment is thus afforded to all classes of sucicty, and what substantial additions are made to the people's 
food, the philanthropist must be ready to approve and rejoice.

Laying-oet of Horticultural Gardens. - In the arrangement of these gardens, the special objects to which they are destined must be kept distinctly in view. When furnished with complete appointments, they include divisions for culinary vegetables, fruittrees, forcing, flowers, shrubs, etc.; in other words, they embrace gardening in all its branches, and so require treatment of the most varied description. Our limits forbid us to enter into full details; we shall, therefore, suppose that a suitable locality in respect to soil and situation has been chosen, and shall content ourselves with throwing out a few hints which may he useful to persons contemplating work of this kind.

The extent of such a garden onght to be a matter of primary and serious consideration. It should be first of all ascertained what amount of expense the average resources of the society are adequate to meet. Financial difficulties always operate most injuriously on institutions of this kind, as they impede or obstruct direct experiment, and by limiting the number of workmen employed, embarrass the superintendents and divert them from their proper work. Such gardens ought nerer to be too extensive; they should rather be small than otherwise. A large flower-garden, to be filled with beds of ordinary annuals, or eren common florists' flowers which have been cultivated perhaps for half a century, is wholly unnecessary. We should even be inclined to abridge the extent of ground sometimes allotted to culinary vegetables: a few plots would be sufficient to cultivate and exhibit the newer sorts. The orchard-ground must always be 
spacious, but perhaps it might be in part reduced by grafting two or three sorts on one stock, and by the eradication of those which have been proved to be worthless. Ample room should also be secured for a collection of trees and shrubs, particularly the latter, of which there are many fine species not generally known in private gardens. In this department the horticultural societies have already done good service. The Arboretum in the garden of the London Society was long the best in Britain, though it must now yield the palm to that in the Royal Gardens at Kew. Such collections shonld be made, if possible, to take the place of those tawdry, insipid, promiscuous shrubberies which are too common everywhere.

We should further be disposed to recommend the special adaptation of a garden of this class to the peculiar wants of the loeality at which it is placed. It is evident that such a garden at Edinburgh may be made a shade or two different from one at Exeter or Cork. In Scotland it is vain to plant a Chaumontel pear as a standard, or a black Hamburg vine on an open wall; experience has pronounced sufficiently ou these points already; but it would be a very proper thing to form a complete collection of the fruit-trees which are found to be suitable for the climate; and it wonld be equally proper to acquire supplies of those new varieties which might be expected to sueceed in that country. So in the eider districts of England, an experimental garden might well be devoted to the determination of the relative qualities of the cider fruits, and to the promotion of that improvement of which they are susceptible. By the adoption of special aims in different gardens, something like a division of 
labor might be attained, raluable knowledge of local peculiarities miglit be secured, and needless expense might be aroided. At the same time, every one will be ready to desire that the great garden at Turnham Green, which is maintained by the affluent London Society, should retain its general destination and full complement of sectional departments, and that from the influence which its wealth, science, and central position fit it to exercise, it should continue to be the connecting link of all sueh gardens in the Empire.

In every case a considerable space of lawn should be left open in some prominent part of the garden for the temporary erection of tents, stages, and other appliances of those flower-show exhibitions which have been found to contribute so much to the funds and to the general prosperity of the societies. These shors, indeed, have prored to be of so much importance that some of the older horticultural gardens have been more or less altered to admit of their extension. The space thus deroted need not be of any formal shape, but it should not be encumbered with too many parterres or figures of shrubs and trees. It should communicate with the more ornamental parts of the garden by means of walks and lawns, in order to extend and diversify the promenades.

Certain of the minor departments of these gardens, such as the culinary regetable section, the propagating grounds, and the forcing fiames and nursing pits, may be appropriately kept within small inclosures formed by means of low walls or liedges, arrangements that are furnd to be highly convenient, as affording seclusion for experiment and slelter for delicate plants. These inclosures require to be masked cxternally. 
The rest of the garden should be rather open, well provided with walks, and the arboretum and flowergarden, in particular, shonld be interspersed and adorned with lawns of varying size. In this quarter there should be a close approach to the aspect of the private pleasure-ground.

The decorated grounds should be ornamented with plant-stoves, conservatories, and green-houses for the growth and exhibition of the rare and showy exotics that require protection or artificial heat. The proper distribution and arrangement of these glazed structures are matters of primary importance. Perhaps there is a tendency to mass them too much together. We do not disapprove of imposing ranges of ornamental glass-honses; at the same time, we prefer the divided interest of groups of two or three houses, so placed as to form prominent objects on the principal lawns. Perhaps some of these should be employed to lighten and dirersify the effect presented on ordinary occasions by the area left open for exhibitions; but to wall in that space all round with glazed structures we think in worse taste than to leave it open altogether.

Speaking generally, we would say that the more decorated parts of these gardens should be in the highest style of the art, and should combine the broad, winding, and varied lawn of the pleasure-ground, with the richly grouped beds and figures of the flower-garden. We may add, that the trees, shrubs, and plants cultivated should not be mere botanieal rarities. Possessed of some intrinsic ornamental properties either of elegance of form or beanty of flower, they, when new, should be presented in considerable masses, in order that they may be introduced to public notice, 
and their decorative value may be clearly ascertained and exhibited to the eye. This is a function properly belonging to horticultural gardens and which, it must be owned, they lave as yet imperfectly discharged. The horticultural prints teem with advertisements of flowers, fruits, and apparatus, for the worth of which the editor's can not possibly be made responsible; and if the ill-advised purchaser trusts implicitly to some of these seductive statements, he will soon find that he is paying dear for his experience. We shonld wish to see all these lauded articles tested in the Horticultural Gardens, and marked with the imprimatur of these societies. Surely fair dealers would find it for their benefit to establish such a practice; at least the protection of the public requires that something of this kind should be done.

Horticultural Museuar.-This is another improvement which we earnestly desire to see introduced. Most of the societies, it is believed, possess drawings, and models of fruits, and dried collections of horticultural products more or less extensive; but they are seldom so arranged as to be easily accessible to strangers, or even to be readily consulted by those in charge of them. Why shonld there not be a spacious room, well aired and lighted, fitted up with glass cases, ete., for the reception of objects worthy of preservation? We would assemble there specimens or models of the fruits and regetables of our own and other climes. We would have an herbarium of the plants and shrubs that have occupied a place of distinction in the flowergarden, as many of these, through the influence of fashion, pass away and are forgotten. Those who lave examined the agricultural musenms now being 
collected in various parts of the empire will easily imagine the benefit which might be derived from kindred collections in public gardens. To these mtrseums we would recommend the addition of a well-chosen horticultural and botanical library, composed not merely of treatises which onght to be in the hands of every one, but of books of reference, such as the works of Lindley, Loudon; Diel, Hooker, De Candolle, Balfour, and others, to which should be added the various horticultural and botanical periodicals of the day, and many other illnstrated works, which persons of moderate fortme, unless they enjoy peculiar facilities of access to public libraries, lave no opportunities of consulting. There might also be a collection of elementary treatises the instruction of the operatives employed in the gardens: indeed, such a library has, with praiseworthy liberality, been formed by the Horticultural Society of London for the benefit of the young men in the garden at Turnham Green. It may seem more connected with our present object to recommend the keeping of a register of observations made from time to time in the garden. In this book we would insert all the judgments formed of fruits and flowers, the reception of every new plant, with its date, the rejection of every worthless article, and the reasons for the same, and all the comparisons of products made in respect to quantity and quality. Selections of the more interesting parts of this information might be published occasionally; but undoubtedly there wonld also be much which, thoingh it might not be of sufficient importance to be presented to the eyes of the world, might yet be highly worthy of preservation 
as a part of the history of the garden and of horticulture in the locality. Under the present system much curious matter is continually lost. An aged and experienced curator dies erery now and then, and the whole store of knowledge, of which his memory was the only record, passes away.

Note.-Scarce fledglings, as we are, in horticultural attainment, compared with the people of Englarid, Scotland, and Western Europe, where so much wealth and patronage abounds, we are modestly, and according to our opportunities, diligently following, but at a far distance, in the track which may lead us in time to matured excellence in this delightful science, and art. When, through individual exertion, and the combined efforts of our numerous horticultural societies, we shall have accomplished the principal objects at which they aim, as we shall to a good degree, we may profit by the sound remarks of our instructor. They are conceived in truth, and decidedly good taste.-ED.

(2.) Zoological Gardess. - These places of public resort, though but recently established, have already received much attention, and have contributed largely to popular amusement and instruction. Formerly, collections of wild beasts were immured in the Tower of London, in Exeter Change, and in other confined localities, or at most were carried about in traveling caravans. The arrangements of the menageries in the Jardin des Piantes at Palis probably first suggested the union of collections of living animals with gardens. This plan, at least, was adopted by the Zoological Soeiety of London, and it has been subsequently followed 
by varions kindred institutions throughout the country. Of course, in all these cases the accommodation for the animals has been the main object, and the garden only an accessory appendage; but neatness and cleanliness are the qualities which we most desire to find in menageries, and with these the trimness of gardens sufficiently accords. Let the necessary buildings be tastefully and conveniently arranged, and we can not conceive a more appropriate filling up of the picture than that supplied by lawns, flowers, shrubs, and trees. For holiday folks, who probably form a majority of those who frequent zoological gardens, the promenade afforded by the neat gravel walks and well-shaven lawns is an agreeable addition to the other pleasures of the visit. Certain it is, at least, that these gardens have been among the most popular places of amusement that liave lately come into vogue

It will be apparent to slight consideration that the proper style for a zoological garden is a nedium between a pleasure-ground and a flower-garden; it may partake of the characters of both in different places, or rather it may be described generally' as a highly ornamented pleasure-ground. It hardly belongs to us to say any thing about the arrangement of the buildings for the use of the animals, except that they may be easily combined so as to form picturesque gronps. Of course, certain roads must be formed from the exterior of the garden and between the sereral buildings, so as to facilitate carriage and transit. Plantations and shrubberies should mask these roads and vail other deformities. Pieces of artificial water may be constructed both for ornament and for the nse of aquatic fowls. 
Walks should be laid down so as to aftord easy communication between the various departinents of the garden. Where the style approacles that of a llowergarden, it should be of the mixed flower-garden described in a previous chapter, displaying an agreeable intermingling of shrubs and flowers. Perhaps flowering shrubs and a mixture of evergreens should predominate. We are of opinion that any thing like excess in the culture of flowers is liere out of place, both as requiring an ill-advised expenditure, and as exciting an adventitious interest. Zoological gardens have recently been made the scenes of flower-shows: at first sight this may seem a grotesque and incongruous combination, but in practice the occasions are pleasant enough, and if they benefit the funds of these meritorious institutions, no reasonable objection can be made to them.

Note.-As every thing in Anerica must be made to pay, we do not see why a zoological garden, rightly got up, may not be made a permanent "institution" of this country, as well as the traveling menageries. The city of New York can certainly afford one. We trust that our country will ere long be provided with an establishment which has proved so attractive an object of interest to the immense population of London, as well as to the innumerable multitudes who flock thither from comtries abroad. In New York, its attractions wonld be none the less, and in the "paying" department, far more productive upon the capital employed than there; and as a school of study, and science, the benefits of a zoological garden would be unquestioned. The department of Natural History 
embracing the varied subjects attached to an institution of the kind is one of exceeding interest to all who lore to investigate the structure of animated nature; and the opportunity thus afforded to the scientific inquirer, would be a fund of lnowledge to those having access to it, as yet but imperfectly understood in this country.-ED. 


\title{
C I A P TER XI.
}

\author{
THE VILLA.
}

Introductory Remarks.

Szcr. I. General Properties of the Villa - The Locality - Thu Site Roads - Position of the House - Style and Arrangement of the House.

SEcT. II. Laying-out of the Grounds of a Villa - Seclusion - The Approacl - Kitchen-garden - Trees and Shrubs - Water - Leading Varieties of Villa Scenery - The Pleasure-ground Villa - The Park Villa.

Probably there are few men, not possessed of ancestral lands, or without the prospect of succeeding to them, and who betake themselves therefore to business, that do not wish and hope, in their outset, to realize so much wealth as will enable them, in the decline of life, to retire to some comfortable villa near their native place, or in some. other locality to which they have become attached. Such visions are not anfrequently realized; and the desire in which they have originated has sometimes led to the amassing of large fortunes, and to the possession of extensive estates provided witl parks and pleasure-grounds. But even if all that is attained is the villa, still, a great good may have been reached. Such residences, whether as retirements from active life, or occasional retreats from business, or the dwellings of competence, are rery generally the abodes of intelligence and refinement. As a whole, they are, perhaps, as happy homes as 
Britain can boast of. Hence their construction and decoration possess an interest, and invite a consideration, which call for careful exposition and study.

Taking the term, residence, to denote not only the house, but the locale ocenpied by the proprietor and cmployed for his domestic purposes, the villa may be described as a sinall residence, embracing the whole of the property laid out in gardens and dressed greunds; or, if it include some picces of pasture-lands, such ouly as are of a linited and subsidiary description. The name, villa, is appliet to places of considerable variety in dimensions - from the honse with a small plot of garden-ground attached, to one surrounded by thirty or forty acres of pleasure-ground and park. Some mansions, belonging to small or moderate-sized estates, are, in their whole character and arrangements, nothing else than vilias; but it is not usual so to designate them; they are rather said to be laid ont in the villa style, though the distinction is perhaps more imaginary than real. In a suburban district, the villa is generally surrounded by a fence of sufficient height to exclude, if not all the scenery at a distance, at least most of it in the immediate neighborhood. In the conntry, however, and particularly when attached to a small estate, it will depend not more on the views connected with the estate itself, than on the prospects presented by the surrounding scenery. Besides its infcrior size, the villa is distinguished by its superior keeping. Its style may be more ornamental, and its finish ought to be more elaborated and more carefully maintained, than is commonly deemed necessary in mone extensive country residences.

onr remarks on the villa may be arranged under 
two heads; the first presenting certain general and preliminary considerations, and the second containing directions for the laying-out of its grounds.

Note.-The people inbabiting the towns of the Northern United States, of all others in the world, are villabuilder's. The villa appear's to be the summum bonum of worldly desire, in the way of ultimate settlement in life; and they are usually constructed with a taste and convenience which, in very many instances, embody all of comfort and luxury to which a moderate family need aspire, in the way of a dwelling. Erected on fine grounds in an eligible position, they combine all the requisites for leisure, quietude, and ease in life, that a house can possibly afford; adding the advantages of social intercourse, and the facilities to the enjoyment of compact town life withont its privations, crowding, and inconveniences. We commend a close study of our author's succeeding remarks to the reader:-En.

\section{Sect. I.-General Properties of tile Villa.}

TIne Localitr.-There are certain circumstances of a local nature whieh are of much consequence to the proprietor of a villa. If he possesses that taste for society which is common to all, except persous of reclise habits, he will find it important to have a pleasant vicinage, and to be placed near a respectable and healthy class of population. When the villa is to be formed in a suburban, or semi-suburban district, it should, if possible, be set down between the city and 
the points from which the prevailing winds blow. Westerly, or sonth-westerly winds are probably the most common in these islands; and therefore the best situations, in this respect, are to be found from the south-east romnd by sonth to the north-west of the city. If easterly winds predominate, the preferable sites will be on the reverse half of the compass; that is, from north by east to sonth. By attending to this principle, the inhabitant of the villa will live in purer air tham le would otherwise do, and will reduce the nuisance necessarily arising from the smoke of the city to its minimum. For the same reason, the vicinity of public works should be avoided. Some of them vitiate the air by the emission of chemical vapors: all are largely productive of smoke; and, not to speak of the bustle which they create on the roads, present, in their tall, staring chimneys, and bulky, unshapely fabrics, objects of contemplation by no means agreeable to the eye. Besides, they tend to pollute the slnggish streams that often flow past them, and to render the whole neighborhood dirty and slovenly. The very worst locality of all, however, is that near the general outlet of the sewerage of a city, and more particularly if the foul contents are applicd to purposes of irrigation, as at Edinburgh. It may be added, that a locality adjacent to a poor and dirty suburb should hardly be chosen. A benevolent man, indeed, will not fail to risit frequently such abodes of poverty, and to do what good he can in them; but he will not find his benerolence increased by obtrusive sights of misery, or by the importunitics to which, by his proximity to such scenes, he is sure to be exposed.

Note.-Happily, the American villa is seldom seen 
anid the noisome atmosphere of sewers, chemieal works, or huge, sooty manufactories. Some of our manuficturing towns boast many and beautiful residences of the kind; but propelled, as the machinery of our fuctories usually is, by water, the locality of the villa is usually in a pure atmosphere, and mnder a clear sky. When otherwise situated, as in the vicinity of our coal districts and iron manufactories, the remarks of our anthor can not be too closely followed.-ED.

True Sire.-Before proceeding to select a site, the future proprietor should be satisfied that he has fixea on a proper locality, and on a neighborhood of easy access. The site, however, is generally much less within the power of absolute choice; probably he will find the best already occupied, and his only resource may be to adopt a secondary position, or to seek for a better in another district, in all respeets not so desirable. The best site is one moderately elevated, witl a warm, sunny exposure. We say, moderately elevated; and this quality should be specially attended to when the general range of the surrounding country is high ; for though some sites, from their elevation, may command superior views, and may afford comparative seclusion, yet these advantages may be more than counterbalanced $\mathrm{By}$ their increased exposure and greater difficulty of access. It is nevertheless very desirable that there should be some tolerable views from the windows of the principal rooms of the house, as these very much promote the habitual cheerfulness of the residence. $\Lambda$ rounded swell or gently-sloping ridge is often a happy situation; for, though it may occasionally suffer from high winds, it will enjoy a purer and drier atmosphere than is to be found lower down in 
the valley. We do not object to flat surfaces, provided they are formed of light, porons soils. Deep clay and retentive subsuils ought, by all means, to be avoided. A facility for perfect drainage onght to be regarded as an indispensable property in a villa residence. The soil should be rather light than otherwise, and certainly should not approach to strong clay, as the latter has a tendency to ereate damp, to make the climate cold and the garden late, to prevent the walks from drying rapidly, and to impart, during most kinds of weather, a raw, uncomfortable aspect to the grounds. It is further to be noted, that direet and immediate proximity to some great frequented thoroughfare is far from being desirable; for in such places the dust, blown from the public road in dry seasons, often amounts to a positive nuisance.

Note- - A clay soil is easy to drain, and then it is better and stronger, for vegetation generally, than the light, loamy, sandy, or gravelly soils which our author so highly recommends. Therefore, we should not regard a clay soil, other things equal, as highly objectionable. A crowded thoroughfare is to be avoided, if possible; but even that may be endured, by throwing the louse well back from the strect, and planting a thick belt of shrubbery next the line:of it. Trees and shrubbery are a great protection from the dust of highways, arising either from winds, or driving over them.-ED.

RosDs.-At first sight, the reader may suppose that the villa has little to do with public roads, as it seldom requires a long approach, and may seem to have no other connection with the subject. Such, however, is too hasty a conclusion. Public roads are of about as 
inuch importance to a villa as an approach is to a mansion-house in the country. Unless the roads in a distriet are well formed and kept in good repair, most of the comfort and enjoyment yielded by an otherwise perfect site, will be in great measure neutralized. What is more disagreeable than to drive or wade through a rugged lane or ill-kept parish road, in order to reach a country house?. To persons abont to form residences in such localities, we would say, Be not deeeived with the idea that these roads are easily ameliorated; the public boards who have the management of them are moved with difficulty, even by individuals who are members of them. Before fixing on a locality or site, see at least that there are well-frequented roads in the neighborhood; for if they are not in good repair at present, it may be hoped that they will not be allowed to continue so. Easy access to public conveyances is also an advantage not to be orerlooked; for, though a gentleman may use his own carriage, some of his family or his servants may find it convenient to avail themselves of the public means of traveling. Even for friends and other visitants, twenty minutes' distance from a railway station may afford a pleasant morning or evening walk.

Position of the House in relation to the other PSRTS of TII Residence.-After arrangements have been made for the purchase or possession of the ground, the proprietor generally proceeds to fix the spot on which he is to set down his house; and the plan is often adopted, and the buildings are sometimes erected, before any attention is paid to the laying-out of the grounds. This is a very grievous mistake. The plan of the house, its position, and the designing of the 
gardens and dressed grounds, should be considered together, and mutually adjusted to each other. Whoi the arehitect is the only person consulted about the position of the house, unless he has a more than ordinary knowledge of landscape-gardening, the only element he will take into consideration will be the securing of a site which, according to his ideas, will best exlibit his powers of architectural design. Most probably the house will be so placed, and the approach so contriced, as to make a decided impression on strangers and other visitors. The place, indeed, will often be little more than an inclosed approu to a house in the center, or perhaps even in an extreme corner of the little domain. It onght to be remembered, that a house is always most effectively, and certainly to its inmates most agreeably seen, when it is so placed as to enable the grounds to be decorated to the greatest advantage. In practice, we have often felt the loss arising from the absence of combined arrangement; we have often been mortified to think that the result of our best endeavor's has been greatly inferior to what it might have been, had the position of the house been more happily selected, or could it have been altered even to the distance of a few feet; and any error committed in this way we have found the more difficult to repair, or even modify, the sinaller the extent of the place. The position of the house should be such as not only to be of easy external access, but to impart to it a considerable degree of seclusion. The internal road, or approach, should not be allowed to traverse much of the grounds. The windows of the principal rooms should command the best portion of the inner scenery, and any thing worth looking at without, that 
can be conveniently brought into riew. These conditions will generally place the honse at no great dis. tanee from what rnay be called the entrance-boundary. In sll villa residences, whether large or small, such at position of the house will enable the proprietor to form a more varied disposition of his grounds, than if it were set down in the center, or toward the more distant extremity. In a small place, the designer will, on this plan, hạre more space for useful and ornamental purposes, while in a larger one he will be able to make a more compact arrangement and a more felicitous combination of his dressed grounds, gardens, and offices, as well as to introduce a larger amount of park and woodland scenery than conld otherwise be obtained.

In support of these views, we might instance some of the finest residences near London. Sion Honse and Holland Honse, though not mere villas, exhibit no affectation of long approaches. At Bedford Lodge, Camipden Hill, a suburban villa of the Duchess of Bedford, the lionse is separated from the lane which leads to it merely by the gate and entrance-court, and wall inclosing the latter. At Mrs. Lawrence's villa of Ealing Park, celebrated for its highly decorated garden, pleasure-grounds, and beautiful little park, from the proximity of the honse to the road by which is the principal access to the place, a very short approach is all that is necessary.

All these examples show the value put on internal space by the owners of these residences. It may be said, indeed, that these are only proofs of the desire to have room in the interior for flower-grounds and shrubberies, and therefore they were likely to be 
adopted by persons having a taste for floriculture. That may be partly true; bit the ground occupicd in them by flower-gardens and pleasure-grounds could as readily have been applied to the prodnction of rmral scenery in general, and therefore may be equally recommended to those who have no special predilection for plants. Certainly, to place the house near the entrance-boundary is the most effectual method of obtaining the seclusion which every one wishes in the country, and securing space for lawns, kitchen-garden, orchurd, pasture-fields, or whatever else a man may set his heart on. Any thing, almost, seems in better taste than an exaggerated and ostentatious approach contrived for the purpose of showing off to stranger's the columns and pilaster's and fine proportions of the house.

Note.-We have scarce a word to add beyond the sensible and fitting remarks of our author, other than to say, that the designs of the architect should be snbordinate to the plan of the grounds, and the plantations upon them. And in the construction of all, the proprietor, in getting them up, should know exactly what will please his own taste, and what he wants of his villa after it is built. In the occupation of the villa, wants and tastes differ so widely, that what would please one would ill suit another, yet each be an excellent house in its way. The purpose of the occupant, in fact, should be the expression of the villa, as much as in a building for any other object. Pursuit, inclination, mode of life, considerations tonching the circumstances of one's family, their social relations - all, should measurabiy govern the internal arrangement of the house, and in some cases, its locality 
witbin the inclosure; keeping in view, hor:ever, an aroidance of incongrnity in what would mar its external effect, and injure its value to one of like tastes and circumstances.

It is well to note, that your retired Englishman is a different man, both in thimself, and in his family, from the Ameriean. The Engishman withdraws into his household walls, from his oftice, or his counting-room, and dimner ends the day with him - ont of doors. The A inerican sallies out to his place of business after his midday meal, returns to his home for "tea," and walks ont in the sunset and twilight to look over his grounds, or enjoys with his family an evening on the reranda. Climate measurably forms the tastes and habits of each; and each will build to comport with his own predilections, and humor. Thus, the one will place the windowless and doorless walls of his house close upon the street, with a forbidding frown to the passerby, while the hidden interior gromds are reserved for the sole enjoyment of his family and friends. The other throws the open, dressy front of his honse to the public gaze, and lays the tastiest portion of his lawn, or garden, out for the world to look upon. Educated to the latter, the American will differ materially in his conclusions from our anthor, who, with the generality of his countrymen, think it to be none of the rorld's business how they live, or what they do inside of their own eastle inclosure.-ED.

Strue and Arralgement of the Hotse-These are subjects which hare probably occupied the attention of a gentleman who has resolved to form for himself a suburban residence, eren before he has taken any steps to procure a site in a particular locality. Examining 
the villas of his firiends, one or other of which he may be desirous of copying, or all of which he may wish to differ from as much as possible; he may be rash enough to make up his mind, as to his future opera. tions, from reasons totally irrespective of the circumstances which should be permitted to modify, if not determine, his choice. We wonld counsel him to leave the style and arrangement of his honse open questions till he has ascertained the nature and extent of the residence he requires, and till he has fixed on the site which it is to ocenpy, as he will then be in a better position to judge how varions matter's connected with them should be settled. In offering some remarks on this subject, we do not intend to give any special directions in regard to either the style or the internal arrangements, except so far as these should obvionsly be governed by their relation to the grounds by which the house is surrounded.

Of course the style of architecture, in villas of even inconsiderable pretensions, will fall to be determined by the peculiar taste of the proprietor, or will be swayed by the fashion of the time, or the prevailing practice of the district. We have seen a few fine specimens in the Italian or the revived antique style, but it may be doubted whether they are altogether suited to our colder climate, and the accessory scenery in which we can array them. Probably we have more numerous instances of a felicitous employment of the Elizabethan, or perpendicular Gothic style, as it is sometimes ealled. We have generally, however, been impressed with a eertain diminutive look presented by detached buildings of this elass. To be effective, they must be massive to a degrce which materially increases 
their expense. For small or moderate villa residences, the most suitable style, we humbly think, is one or other of those forms usually called cottages: and as there is a great variety of these, an architect can be at no loss in furnishing or suggesting such a number of designs as will afford materials for a good selection. The raried outlines and low elevations of honses in the cottage style harmonize better with the limited scenery of a small residence than those huge square masses of brick or stone and mortar which are frequently seen overlooking, and as it were orerpowering a place of three or four acres. The affectation of Grecian architecture has generally led to a tame uniformity in villa mansions. The pattern followed in many eases is, with some slight variations, the street house, that is, a house with a main door in the eenter, and a dining-room and drawing-room on each side of it. So long as this fashion prevails, there can be little hope of improving small residences. Except in special eircumstances, one or both of the principal rooms above mentioned should be on the side of the house opposite to that in which the principal entrance is situated; or, if this cannot be effected, they ouglit to be in a line at right angles to the main-door front. It is indeed convenient to have a window toward the entrance for the inspeetion of approaching visitors; but that can be easily accomplished by directing one e. Id of the dining-room or parlor to that side of the hcuse. In suburban residences, it is desirable that the public rooms should eommand the whole or the greater part of the decorated grounds. The drawingroom will occupy the best position, followed by the parlor, dining-room, and library in succession, each, 
if possible, having some advantage of its own, though in an inferior degree. The proper position of a conservatory or green-house is in connection with the drawing-room, and communicating with it by a glass door; it will thus not only be an object of interest in itself, but it will form an extension of the drawingroom, and will afford an agreeable lounge in wet weather. For this purpose the passage ought to be roomy and unencumbered. In green-houses this convenience is too often neglected, and the floor is overcrowded with stages and shelves for the reception of plants. A plant-house of easy access, with wide passages, and a smaller number of well-grown plants, may be tenanted by objects highly worthy of admiration, and will prore a most pleasant adjunct to a drawing-room. If the conservatory or green-house can not be united to this room, another position may probably be found for it in connection with some of the other public rooms. A green-house of all work, as it is called - that is, a glazed house for the general protection and propagation of plants - should not be immediately accessible from the mansion, as it can not be kept in sufficient order to warrant such proximity. Its place should be in the kitchen-garden, or on the clge of the flower-garden.

It will be inferred from what has been stated above, that the entrance-front of the house should, other things being equal, be placed toward that direction which $i_{3}$ least favored in point of view, or where there is litt.e or no beauty to lose. We do not mean that the principal door should be thrust into some obscure corner, but that it should occupy a secondary position in relation to the grounds and the public rooms. In that case 
the drawing-room front will receive the chief attention of the architect. In some of the best-laid-out villa residences that we have seen, the main door fices an adjacent bonndary wall of considerable height, and is separated from it merely by a graveled court of sufficient extent to afford room for the turning of a carriage. In other well constructed places this court is wanting, and its place is occupied with flower-ber's and shrubberies, with a covered way communicating with the main door at one end, and with the entrance-gate in the boundary wall at the other. Of course, in this arrangement, carriages are left on the outside altogether. A small door at the end of the house opening on a back court or road between the kitchen and stableoffices is used when it is needful to bring a carriage close to the house. A kitchen-court should be formed at one end or side of the house; and if this is the only court that is necessary, and the house is near enough to the boundary, it may be brought out to the external wall. When stables are required, they may be placed in connection with the kitchen-court, or if there be room and acess, they may be built at a little distance along the boundary wall, with a separate entrance, for example, in a corner of the property. The respective positions of these courts must vary with that of the louse itself in reference to the other parts of the residence; lunt they should never occup; more than one end or side of the house, and should leave the remainder of it to be surrounded by the ornamental grounds. To these apparently minor points we solicit the reader's earnest attention, as success in these arrangements, which are very apt to be orerlooked at first, has a most material effect on the general result. 
Note.-If there be a minor rice in which the American is prone to indulge in the way of money-spending, it is that of orer-building. Not that he builds too well, too substantially, too conveniently; but he builds too pretentiously, and too much. It is needless to particularize, but the fact readily occurs to any man who understands the real properties which a dwelling requires. It is not uncommon to see a house with more filagree and gingerbread work upon the top of it, (which is of no possible use whaterer, either in the way of ornament or finish, but an absolute damage to the whole structure by exposing it to decay,) than would, at the same cost, finish half the rooms within it. Any quantity of meaningless gables, turrets and battlements are stuck up by way of imitating certain ancient styles of architecture, and which, in their paltry dimensions, are only a burlesque upon the grand old structures they thus attempt to copy. These are termed Gothic, Tudor, or Elizabethan. Others are seen having high, shallow porticoes, with massire columns supporting the gable end of the louse, by way of pediment, giving to the front neither shade, shelter, nor protection, but exposing a wide, glaring front, looking, in fact, more like a building for public uses than a private drelling. These may be called Grecian, Moorish, or Romanesque - all false in style, as comporting with the idea of snugness, cou^fort, and really good taste -- features which a dwelling-house of any character should always express. In the first category, of the Gothic, and others, every essential feature may be sacrificed to give a bay window in the first, or an oriel window in the second story a conspicuous front, while the main entrance-door, which should in all cases be shown, is 
tucked away in some by-corner where the family and its guests must apparently sneak around some projecting angle into it for fear of observation. In the other, every thing else is sacrificed to a showy entrance-door with its flashy dressings, and a splendid approach. The architect of true taste will do neither. IIe will take a medium course, and show that his dwelling has hoth an approach and a front door, and give his parlors and principal rooms a good position to command, eacl in their own character, a proper view of the most eligible points belonging to them. Climate must somewhat govern in all these arrangements, and as onr author writes for the humid, cloudy skies of Britain, we differ somewhat from his recommendation of throwing the main entrance-door into a "secondary position in relation to the grounds and the public rooms." In American climates the principal door should be seen at once by every one who approaches the honse, and the approach to it be bold and ummistakable. A reranda to a viila we would always have, let the style of builling be what it may; and this veranda shonld not, unless for some extraordinary purpose, such as commanding a surpassingly fine view, or sheltering some exposed part of the honse, be carried above the first story. It should be broad, never less than ten feet for a substantial villa, and in some cases twelre. A narrow, pinched reranda is a pretense only, and should never be built. For all useful objects and appearance, the bouse is better withont it.

Stables, and stable-yards, and the approaches learling to them, should be thrown as far from the homee ns due conrenience, and the area of the grounds will admit. Stables breed innumerable flies in hot weatlıer, 
and if near the house, the latter become an intolcrable pest. This, and the odors created by them, should be well considered in whatever relates to their location.--En.

Sect. II.-The Laying-out of the Grodnds of a VILLA.

We take up this subject, in the second place, because the execution of the works which it embraces is generally postponed till the completion of the house and offices. We would again, however, insist on the expediency of obtaining a plan of the grounds along with the plan of the house; as very much of the effect of both will depend on their mutual adjustment. In a work of limited extent, like the present, it would be inconsistent with the design in view to give formal and detailed directions for the laying-out of villa residences. It is evident that the designs must vary considerably along with the diversified dimensions and surfaces on which they are to be executed. At the same time, the general principles involved in the designing of parks and pleasme-grounds will regulate the enviruns of the lonse, proper allowance and modification being made fur the more limited extent of the latter. The grounds of the villa should, generally speaking, present a miniature example of the finest portions of the pleasure-grounds and park. Its scenery, indeed, may partake more or less of either of these, or may conbine the character of both; in other words, we may have the pleasure-ground villa or the park villa, or a union of the two varieties. The peculiar character to 
be elicited must be determined by the taste of the proprietor and a due consideration of the nature of the ground. While, then, we would refer the reader to the earlier part of this work, we would offer some special remarlss in the way of aiding the application of the principles already inculeated. These may fall appropriately under the following heads :

(1.) Seclesion.-This is a quality more or less desirable in all small residences; and in the vicinity of large cities, it may be regarded as indispensable. Of course it does not consist in the exclusion of light and air; neither does it suppose the shutting-ont of fine views, whether at hand or at a distance. It is rather the protection of the family from that exposure to public gaze which would prevent them from using any part of their grounds as fieely and comfortably as they would their drawing-room. A certain amount of priracy, at least, is essential to that rural feeling which is a principal charm in retirement from the bustle of city life. Some indiriduals, indeed, seem to have a particular fancy for displaying their flower-beds and lawns to the eyes of the public; a taste, we humbly think, more suited to hotel establishments than to the abodes of private families. We would have the greater portion of the villa grounds to be possessed of the character's of complete seclusion. At the same time, the error arising firom the excess of this quality - the dull, gloomy insipidity eaused by over-planting and an orer-affectation of priracy - is to be carefully gruarded against. On level or gently-sloping surfaces, the proper amount of seclusion may generally be obtained by building the boundary walls from eight to ten feet high. On surfaces with a considerable declivity, such $12 *$ 
walls will be found insufficient; and as no considerable addition can be made to their height, nor indeed, if added, would prove effectnal, the object aimed at must be attained by planting trees and shrnbs, which will have to grow for several years before they afford the desired shelter. $\Lambda$ s the size of villa resiclences increases, the difficulties in regard to priracy diminish, as there is room for enlarged masses of trees and shrubs, and the whole place naturally assumes the character of a common country residence.

(2.) Tife Approscir.-As remarked in the previous section of this chapter, small residences seldom require an approach of any great length. The smaller the quantity of the ground occupied in this way, the greiter will be the extent capable of being devoted to useful and ornamental purposes. TVe do not say that the approach to a small residence may not be made in some measure ornamental; but in its formation, its peculiar use ought to be principally kept in view, and any decoration connected with it shonld be made subsidiary to the adornment of the other parts of the grounds. We shonld be disposed to line them with groups of shrubs, or to screen them with hedges of crergreens, so that they should not interfere with the general privacy of the place. It will be found that the approach is seldom used as a walk or lounge by the members of the family, eren when it is not exposed to the external world. In a former page it was stated that in some admirable villas there is no approach, in the proper sense of the word; that its place is sometimes taken by a graveled court or corered way; and without doubt the adrantages of such arrangements, if they do not supersede the necessity of 
an approach altogether, certainly reduce it to a minimum. Of course, such expedients can be adopterl only in farorable circumstances. Tluere may be elements in the size of the place, or in the slope of the ground, or in the position of the most favorable site, which demand an approath in the ordinary form; still the line leading from the entrance-lodge to the house should, witlont falling into a straight line, be as short as possible. Passing the entrance-gate at right angles, or nearly so, to the bomndary wall, it slonld proceed with such a moderate curve or sweep as will place the sicle of the carriage abreast of the main door. The approach should nerer be carried across the entrancefront before reaching the door of the honse, unless the ground is so steep as to render the formation of a road with an easy inclination otherwise impracticable. A lodge may sometimes be a necessary appendage to the entrance-gate, and that is a sufficient reason for a moderate prolongation of the approach. Certain fine views, or other advantages, carrying the house considerably into the interior of the territory, may make a similar demand; still, it should be an object steadily kept in view, that on this acconnt there should be as little intersection of the grounds as possible. When the whole place approaches the form of a parallelogram, the gateway and lodge may be placed in one corner, and the approach may fill into a straight line, or form an avenue along the boundary, till it is necessary to curve off to the door of the house. When these residences increase in size, they assume the appearance of a park, and of course the approach will follow the character of those required in such places. It is not unusual to find two approaches to a villa 
entering from the same line of road, and at points within a hundred yards of each other; a fict which indieates an excessive love of road-making, for one ought to be sufficient for the requirements of the place. When a communication with a separate line of road is needed, a second approach is not only excusable, but it may he necessary, though it will geneially encroach coilsiclerably on the privacy of the grounds. We do not pretend to give such directions on this subject as will nect every cxigency. Tarieties of situation are continually occurring, which must be treated with a reference to their own peculiarities. We may, howerer, remark in conclusion, that villa residences are more frequently spoiled by ill-judged attempts at fine approaches than by any other mistake, except, perhaps, the wrong selection of a site for the louse. We know scarcely any thing in more miserable taste than a house with a broad mural façade and a door in the center, standing far back in a vista, and occnpying its whole width, while the foreground of the pieture is taken up with a disproportionate road winding across the grounds, and leaving space in its flanks only for illgrown turf or paltry slirubberies, or, what is worse still, lines of potatoes and cabbages, and the necessary déstubille of uninclosed kitchen-ground. The disappearance of such sights is surely derontly to be wished.

The Titcuinn-garden. - Where the taste of the proprietor inclines chicfly to the possession of ornamental grounds, or to the cultivation of fine plants, want of space may require the omission of the kitchengarden, and in the vicinity of regetable markets the privation may be inconsiderable; but in most places, and particularly in remote districts, the enlinary 
department of the garden is at once a necessary and an interesting appendigge to a villa. It requires a compartment separite from the ornamental grounds. The proper site must be determined by the lay of the ground, and especially by the arrangements of the house. Obriously, the kitehen-garden should not be on the entrance or drawing-room fionts; or, if it must be placed on these sides, it shonld be removed to such a distanee and screened in snch a way as to eoneeal all disagreeable objeets, and so as to obstruet the general seenery as little as possible. The most convenient position is elose to the stable-offices, as that will ficilitate the introduction of manure and the removal of rubbish withont injury to the walks or dressed grounds. It is desirable that the site shonld be warm and sheltered, with a sunuy exposure and a dry subsoil. If the proprietor desires to have fine wall-fruits, proper walls must be built for their cultivation. These should not exceed twelve feet in height, otherwise they will often be injurious to the scenery of the place. The boundary wall may oceasionally form part of the inclosure of the garden. Walls formed or lined with brick are the most suitable for the training and culture of fruit trees. Stone is also a good material, when tormed of a proper size, and earefully dressed, and well built. On steep declivities, the walls may be made the facings of terraces, the intermediate surfaces of which are ocenpied with regetables. Of the other buildings conneeted with the kitchen-garden, the melonry and pine-pit should form a separate compartment, either in the interior of the garden or attached to it; the vineries and peach-houses may oceupy suitable places on the walls, or may stand in detached 
situations, as may be found most convenient. The latter forcing-houses may sometimes be erected with propriety in the dressed grounds, and along with the green-house may form a connecting link between these grounds and the kitchen-garden. The farorite form of the kitchen-garden is the square or parallelogram, and these are nore compact than most other forms, and have many conveniences; but it would be injudicious to disfigure the internal scenery of a place by a servile adherence to any particular plan, when one perhaps equally good, though not quite so regular, can be had by the adjustment of the outlines to those of the ground, or to the positions of surrounding objects. The kitchen-gardens of small residences should be exclusively devoted to fruits and vegetables; by that means they are more easily kept in order. Where orchards are planted, they should be connected with the kitchen-gुarden, or its immediate vicinity; a few pretty groups of apple, pear, and cherry trees might be formed on some of the less conspicuous portions of the lawn.

(4.) Tries and Shrubs as the means of DecoraTION IN VILL.AS.-In the marine residence and in the mountain shooting-lodge, trees and shrubs may be awanting altogether, or may exist in only small quantities, without their absence or their pancity being sensibly felt. In some marine residences, they can not be grown except under the shelter of a wall or rock; but to the taste of many, a varied shore and an unlimited expanse of sea, with its incessant changes, afford an ample compensation. Again, in the alpine shooting-lodge, the raried ontlines of hill and glen, of crag and ravine, of lake and waterfall, of trailing 
mist and glimpsing sunshine, may afford such magnificent and entrancing scenery as may make the transient inbabitant forget the softer beanties of trees, except when he is reminded of their shelter by the cutting breatl of the mountain wind. It is hardly worth while to spend much labor on the culture of trees and shrubs where they grow with difficulty into stunted forms, and where, eren in their finest derelopments, they would be wholly eclipsed by the grander and wilder features of nature.

But it is different with the ordinary, and particularly the suburban residence. They hare seldom the sublime accompaniments of the broad sea, or of the blue ridgy mountain. Trees, shrubs, and flowers, are their principal means of ornament. Deroid of these, they would only be like a house in a bare field, or " a lodge in a garden of cucumbers."

In the villa grounds, trees can not be formed into woods, but they should be introduced into the larger masses of shrubs so as to heighten their eflect; in other places, they may be sprinkled on the remoter parts of the lawns, and so may unite with the former in making up an appearance of woodland scenery. Some of the more rapidly growing linds should be inserted in the shrubbcries of nerr-made places, for the purpose of inparting a clothed effect at an earlier period than can be accomplished by shrubs alone; but where not intended to remain, they should be carefully weeded out when the olject wanted has been attained by their neighbors of slower growth. Breatths of trees and shrubs are needed to clothe and diversify even a small place when new; but they should not be planted to the cxtent of orer-crowding, and should be 
rigidly thinned out at the proper time. A greater variety of kinds may be introdueed into a small residerice than into an equal space in a large park or pleasure-ground; for two trees or half-a-dozen of shrubs, tall and well gromn, will prodnee in the former a mass of foliage and a breadth of effeet which would have but an insignificant appearance in the latter. The oak, elm, horse-chestnut, and plane may be admitted, but only in comparatively small quantities of each, in order to leave room for the ordinary hardy exotic trees and shrubs, which in a small place produce a variety and awaken an interest not to be derived from the most skillful arrangement of the more common sorts. Small groups may be formed of varions kinds of trees, such as oaks, maples, ashs, planes, and pines. The ordinary broad-leaved shrubs may afford materials for the prineipal masses of erergreens; but a considerable variety of others may be grouped along with them. The low-growing sorts, such as the Rhododendron ponticum and some of its eongeners, should be planted round the outsides of those of taller stature; and when the clumps on the lawn fill up and merge into masses, the united effect adds much to the raried beauty of the groups.

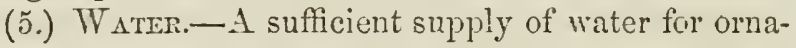
mental purposes can not frequently be obtained in the limited domain of a villa. Where it is to be had, and the cast of ground is such as to warrant the use of artificial water, a small lake will be a pleasing addlition to one of the principal lawns. Its position and form should be regulated by the principles laid down in the chapter on water. Fountains, too, are desirable ornaments in a place of minor extent; one will 
generally be suffieient, and it may be put in a prominent position on a lawn, or be made a center-piece in the flower-garden.

(6.) The Thaning Tamieties of Vilia Scenery.At the beginning of this section we liave mentioned a distinction which we shonld be glad to see generally recognized and observed in the laying-out of small residences, viz: the predominance in each ease of the pleasnre-gromil or park charaeter, according as the nature of the ground may suggest, or the taste of the proprietor might dictate. We would have the pleasure-ground villa and the park rilla, and we would employ in each a distinetive style of ornament. In the following remarks, which are to be supposed as applicable more particularly to residences of firom three to ten aeres, we shall endeavor to keep this distinction in view. When the domain extends to twelve, fourteen, or twenty acres, it may be treated rather as a park than as a villa.

The Pleasure-grouxn Villa.-In this, the more ornamental form of a minor residence, the whole of the ground not covered by the house and offices is taken up with the gardens and dressed gromnds. The lawns are, speaking comparatively, of considerable extent; the groups and clumps of trees and shrubs are very mueh as are common in pleasure-grounds of moderate dimensions, and the execution of the whole is eareful and unobtrusirely elaborate.

The first object aimed at is, by means of a skillful distribution of the principal masses of trees and shrubs, to conceal the kitchen-garden and oflices, and more partienlarly the boundaries of the place. The approach, too, should be screened or masked. The next 
object is to lay down one or two of the principal lawns, so as to have the appearance of considerable extent as seen from the windows of the public rooms. It is possible, by means of masses and groups of shrubs, to convey the idea that these lawns branch off indefinitely, while other minor lawns, separated by the interposition of shrubs, may seem to be connected with the former by smaller breadths of grass. While the principal lawns have for the most part a clothed aspect, it is desirable that one of them should be made to show a large extent of length and breadth of grass, wholly free from the interruptions which numerous flower-beds and single trees and shrubs injudiciously placed are sure to produce. In the margins of the lawns, and especially of the principal one just alluded to, the masses of trees should be so formed as to present a varied outline of projection and recess; without, there can not be that breadth of light, and depth of shade, which are so rich a source of beanty in picturesque scenery. The recesses of the lawns will afford room for groups of flower-beds, or even small flowergardens for the budding-out of green-house plants, annuals, etc. In some of these nooks, too, rosaries ant collections of American plants are furnished with appropriate homes. Rock-works, grottoes, bowers, houses, or covered seats formed of combined moss and wickerwork, may be attached to the flower-gardens, or nay be placed as detaclied objects in the gromals. It is not advisable, lowerer, to confine the whole of the roses and flowering plants and shrubs to particular places; the ornamented style aimed at permits then to be scattered liberally throughout the whole place. Narrow flower-borders and small flower-beds, destined 
more particularly for spring flowers, may be formed near the honse, but are not to be permitted to interrupt the continuity of the principal lawns.

There onght to be at least one principal walk, not less than seven fect wide, leading through the grounds and exhibiting the main objects and positions of the place. A number of secondary walks will also be required to afiord access to sume of the ornaments abore specified, and to facilitate the inspection of the flowers. They should not be allowed, howerer, to trench on the glades of the lawns. Narrow walks should be aroided, except when connected with groups of tlower-beds.

Terraces and bowling-greens may often be introduced with excellent effect, the former in combination with the house and flower-garden, the latter in some of the more secluded lawns. Tases form suitable additions to the terraces and flower-gardens; a sundial may likewise find a place, and a group or two of statuary; but this last requires to be sparingly and tastefinlly employed.

The inner surfaces of the boundary walls should be corered with ivy, which will present a mantle of verdure at all seasons. It is well to do this, even where trees and shrubs are placed in front of the walls, for they are often more conspicuous than they ought to be in the winter and spring months. Portions of these walls may be rendered interesting by having halfhardy climbing plants placed against them in spaces of six or seren feet broad. To afford protection to these exotics, it is a good expedient to plant between the abore-mentioned spaces vigorous specimens of ILagnoliu grandiflora, sweet bay, arbutus, and common 
laurel, trained up to cover three feet in breadth, and to project eighteen inches or two feet. These evergreens, if well kept, will not only form fine verdant columns, but will be found to yield a considerable degree of shelter to the more tender plants trained in the internediate spaces. The walls of the honse, as also the porches and verandas, may be decorated with climbing plants and shrubs.

The pleasure-ground villa is gencrally the choice of the botanist and flower-fincier"; and in the vicinity of cities it is often the abode of those whose wealth permits them to indulge a taste for fine scenery and elegant decoration. As being more complicated, and more carefully furnished in all its parts, it requires a larger outlay at first, and a more laborious, and therefore more expensive keeping, than the plainer form, on which we now proceed to offer some remarks.

Tine Park Villa.-In this species of villa, from one-half to two-thirds of the whole area is taken up with pasture-land, arranged into one larger or two smaller fields, to suit convenience; while the remainingr space is allotted to the house and its offices, the kitchen-garden, and lawns with the appended shrubberies. For example, and without laying down any proportions to be adhered to invariably, say that the whole ground to be operated on amounts to seven acres; we may suppose that half an acre is occupied by the site of the house, offices, and their relative courts; that one acre is allotted to the kitehen-garden, and another acre and a half is distributed among the lawns, shrubberies, and approach; there would be left funr acres for pasture to be grazed by sheep, or by a few cows, or a horse or two, as the wants of the family 
might require. In this way, the rhole place might be arranged so as to be a miniature representation of a park and pleasure-grounds on a larger scale. The grass field, then, thus promoted to the dignity of a park, may be formed on one side or other of the house, or may surround it on two or three sides, and should constitute the principal lawns. It may be divided from the dressed grounds by wire fences or iron hurdles, which, from their lightness, are better adapted for the internal fencing of small places than walls and liedges. It may also have a few small groups of trees irregularly scattered, but not dotted over it. The dressed grounds should be attached to the house; but a curtain of trees and shrubbery will be necded to encircle the little park so as to sereen the boundary walls where these are too conspicuous, to shelter the kitchen-garden, and, in short, to conceal any thing that is objectionable. It may sometimes happen, however, that the extreme rerge of the field may seem to pass imperceptibly and harmoniously into the adjacent property, and if there are no special reasons for making the distinction, the ring curtain in that quarter inay well be dispensed with. The finest part of the pleasure-grounds should be between the house and the pasture-field, and both should be laid out so that the one should appear a continuation of the other. As recommended in the other form of a villa, a considerable variety of trees and shrubs should be planted in the grounds. Besides the walks in the immediate vicinity of the house, one leading walk should pass round the boundary, communicating with those in tho kitchen-garden, and also with the approach, if there is one. A small lake, a fountain, vases, and other 
artificial decorations, may often be introduced with good effect, but only sparingly, on account of the limited extent of the dressed gromnds. The litchen-garden, with its structures, may be placed at one end or along one side of the place, as convenience may dictate. If the approach comes in contact with the pasture-field, it should only skirt the side of it, and should be partially shaded by groups of shrubs and trees.

The park villa is often a very agreeable, and, thongh plainer in its style than the other, a very beautifu] residence. If well-arranged at first, it is the more easily managed of the two. Where only a moderate amount of forcing and green-house work is required, one man, with occasional assistance, or at most two men, will be sufficient to keep a place such as that described above in perfect order.

Note.-The several subjects comprising this section. are so well and so fully diścussed by our author, that hardly an additional word is required. The fervia sun of an American climate will relieve the proprietor of much of the walling recommended for the protection of his plants, and promoting the growth and ripening of his vegetables and fruits. Of all these the intelligent eultivator will be a competent judge; and in the general scope and good sense of the remarks before us, no one need make a wide mistake in cou structing a complete house, and surrounding it wil i $_{i}$ the most desirable grounds. 


\section{CHAPTER XII.}

GENERAL OBSERVATIONS ON THE LAYING-OUT AND IMPROVEMENT CF GROLNDS.

Landscape-gardening-Aualogies to Jandscape-painting - Comparative Power orer Materials - Simplicity and Jiultiplicity of Points of View - Processes wholly and partly Tentatire - Propriety of Rerision - Utility of Plans - Hazard of Preparatory Operations.

Ix the preceding chapters, we have adhered, as closely as possible, to practical views of the subjects which we have treated, and we have carefully abstained from all merely theoretical reasoning. Our preparatory studies, however, as well as our experience in the exelcise of the profession, have led us to some general conclusions regarding the principles and the practice of the art, which it may be proper to bring under the notice of the reader, both as conducing to the unity and as adding to the completeness of the work. To a brief exposition of these conclusions, then, we shall devote this ehapter; and we shall allow our remarks on principles to run at once into their practical applications.

The name, Landscape-gardening, usually given to the laying-out and improvement of grounds, suggests some considerations worthy of attention. Sir Walter Scott, in an interesting paper reprinted from the 
Quarterly Review, in his miscellaneous works, disapproves of its being called gardening in any sense. "The art," he says, "has been unfortunately named. The idea of its being, after all, a varicty of the gardening art, with which it has little or nothing to do, has given a mechanical turn to the whole profession, and certainly encouraged many persons to practice it with no greater qualifieations than onght to be found in a tolerably skillful gardener." (Prose Works, vol. xxi. p. 104.) In these observations, there is nudeniably some truth; though it may be urged, on the other hand, that a gardener is as likely to be a snccessful designer as the forester, the bailiff, or the road-surveyor, or even the amateur, to whom the work is occasionally intrusted. Unquestionably, the artist employed in this department ought to have a special and professional training; but it may also be asked, Is not the other part of the title, Landscape-gardening, a little too ambitious, and does it not proceed on an analogy calculated to mislead, and therefore to disapjoint? It is well known that the exponders of this branch of art have adopted some of the principles and employed very much the langnage of painting. The artist in our departmenc is supposed to create a lancscape in living nature, just as the painter ereates une on canvas. The comparison thus instituted between the two arts, implies that there are certain resemblances between them; but if there are resemblances, it is no less eertain that there are differences. A brief consideration of these harmonizing and antagonistic points may afford us some light, and will enable us to make most of those general observations which we have proposed to offer. 
First, the Landscape-painter may copy with the most scrupulous exactitude some piece of scenery actually existing; and such is the wonderful benuty and diversity of nature, that if his selection has been felicitons, the result may be anong the most truthful and successful of his efforts. The Landscape-gardener can seldom copy. He nay indeed fall into that sameness of style which constitutes mannerism, but he can never servilely copy; for eren on the most level surfaces his materials are not often the same, and the relative situations of his permanent.objects are almost always different. He is bound to create views, if we may here use a word of so much weight of meaning; in short, his business is what is technically called composition. This circumstance makes his work parallel to what, we believe, is the highest line of landscapepainting, viz: the formation of pictures by the combination of the finest objects which the artist las copied into his skctch-book, or can recall by his memory, or call embody by his imagination. But here the painter has some important advantages. His canvas is at first a tabula rasa, a wholly unoccupied field, and his objects are fully at his command. He can put down rocks here, and water there, and buildings and trees wherever the rules of perspective or the management of his distances render them admissible. The Landscape-gardener has most of his objects laid down to him. He must accept of the locality with its natural features, and the contour of the ground, which often prescribes a particular treatment; and he must make it his business to conceal deformities, to elicit existing but unapparent beanties, and to adorn whatever is. susceptible of improvement. It is true that in these. 13 
seeming disad vantages there is also some real compensation. If his broad terrene canvas is not so pliant and submissive to his will as that of a painter-if he has not so clear a field aud so absolute a command over his objects - yet the very difficulty and peculiarities of the locality are often suggestire of his most admirable results. Sir Uredale Price, in one of the notes to his well known work, records the practice of Zucchi, a celebrated Roman painter of castellated scenery. It was the method of that artist, first to clash off a large rock, the nore diversified and picturesque the better, and he then proceeded to build his towers on this crag and on that, according as he could find fomdations for them; and it was generally observed that he was successful in his castles in proportion as lie had been happy in constructing their rocky bases. IIere it is easy to perceive the process by which pictorial effects were suggested to the mind of the painter. More subtle, and therefore more untraceable, may be the operation of suggestion, in the practice of Landscupe-gardening, but not less certain is its inflnence. TVe believe that many of its happiest effects have flowed from this source; and on the other hand it would not be difficult to recount some lainentable instances of failure and error arising from neglect of this principle. The practical conclusion is, that the artist should nerer renture to design, much less execute, till he lias made himself thoroughly acquainted with the natural and acquired characters of the ground.

Again, the Landscape-painter has to deal with no more than one view at a time; and he can not only place the spectator at the point most farorable for contomplating it, but by certain modes of treatment he 
can compel attention to the foreground, the middle dis. tance, and the extreme distance, as he plcases. In these respects the Landscape-gardener is by no means so fortunate. It is true that he too can learl the eye to certain definite objects, though in this his porrer is comparatively limited. His greatest difficulty, howerer, is, that his points of riew are continually changing. A scene which is really beautiful, as viewed from the window of the drawing-room, may appear tane at the end of the terrace, or, as seen transversely from some point in the grounds, may exhibit little else than incongruity and confusion. These are defects which of course are to be abated or concealed. Besides one or two leading viers, numerous subordinate scenes may have to be elaborated in the same range of grounds - as many, in short, as, were they painted, wonld fill a gallery of moderate dimensions. ITere the prineiple of intricacy comes to the artist's aid, if he is only skillful enough to employ it. There is also a boundless variety in the expression of trees, which of ten supply most beantiful and interesting pieces of verdure apart from the main beauties of the place. Distant prospects into the adjacent country are also a useful and often an arailable rescurce. It may be assumed as an axiom that a residence with a single fine view will speedily prove a wearisome one. The visitor will admire the show-scene for a little, but he will soon turn away from it, inquiring, "Is this all? lave you no inore pictures in your gallery?" To meet these demands the artist must provide a variety of food for the eye, which is quickly sated and wearied with miformity. But to effect this he must not only possess invention and industry in himself, but be must 
be allowed time and opportunity to exercise them. If he is called but once to lend his aid, and perhaps with an intelligible hint that the sooner he is done the better, he may proceed rapidly to work, and in the brief period conceded to him may do wonders; but the more quickly and clearly he conceives the plan of the one grand view, if there be but one, and the more perfectly he carries it into execution, the more likely he is to leave every thing else an entire barren. A man may thrust his preconceived fancies on a place as fast as he can stake them ont; but if the treatment is to be adjusted to the ground, and if harmony and variety of effect are desired, as they always onght to be, time should be given for the laws of suggestion to come into fiee play.* Here an intelligent and tasteful proprietor may render efficient aid, and of that aid a sensible artist will always be glad to avail himself. Even the expression of a feeling of want, though what is wanted is not distinctly perceived, may direct the attention of the designer, occupied with other things,

s "According to the common process, their time (that of improvers) is estimated at a certain number of guineas per day, and the party consulting them is not unnaturally interested in getting as much out of the professor within as little time as can possibly be achieved. The lanilscape-gardener is therefore trotted orer the grounds two, three, or four times, and called upon to decide upon points which a proprietor limself would hesitate to determine, unless lie were to visit the grounds in different lights and at different seasons and rarious times of the day during the course of a year. This leads to a degree of preeipitation on the part of the artist, who knows his remuneration will be grudged unless he makes some striking and notable alteration, yet has little or no time allowed him to judge what that alteration ought to be. Hence men of taste and genius are induced to act at random; hence an habitual disreFard of the genius loci, and a proportional degree of confidence in a set of general rules, influencing their own practice, so that they do not receive from nature the impression of what a place ought to be, but impress on nature at a venture the stamp, nuanner, or character of their own practice, as a mechanic puts the same marks on all the goods which yass through his hands."-Sir Walter Scott's Prose Works, rol. xxi. p. 705 . 
to some bald or fecble point, and so by stimnlating invention may lead to valuable results.

Another point of comparison between landscapepainting and landscape-gardening, which presents at the same time an analogy and an important difference, is to be found in the manner in which the designs contemplated are respectively carried into effect. In painting, there is, or at least may be, something tentative or experimental, running throughout almost the whole of the processes which intervene between the first conception of the picture and its complete execntion. The artist, if engaged in composition, traces his outlines on his canvas; but he can alter them as he goes along, and probably his success, or the want of it, in one part of the picture, will suggest a corresponding or compensating feature in another. Even when approaching a conclusion, his work is yet open to change, though such liberties may then be most unadvisable, still change is possible; but when the last touch has been given, the picture is finished, and will continue so, as long as the color's and other materials endure. All along the work has been wholly in the artist's porrer, and he has the felicity of completing it, and stamping even its minutest parts with the abiling impress of his own mind.

"I also am a painter?" says the Garden Artist; and it is true that lie creates a raried scenery; but neither. are his materials nor his operations so entirely under his command. Trees and shrubs may be regarded as his colors; but how ineffective and nntractable are these, when compared with the pigments on the painter's palette! And his processes are only in a slight degree tentative, at least so far as he has immediately 
to do with them. He can alter his plans, indeed, while they exist in his own mind or on paper, or even while he is tracing his outlines on the ground. But it is to be remembered, that the outline, or ground-plan, as it is ealled, is only the skeleton, if it be so mueh, of scenery which is to appear in relicf, in the form of trees anc other elements of landscape. The process is only begun when the ontlines are staked out; many other agencies and inflnences must operate, before the contemplated result is realized. Other artists, if we may so call them, liave to take up the brush and palette-the processes of nature, to sum many activities under one term - and the axe of the woodman must have had free play, before the effect designed by the prophetic eye of taste ean be accomplished. The aspect of woodland scenery changes more or less perceptibly every successive year. Suppose that the rudimentary appearance of a park, ten years from planting, could be accurately compared with its full-grown aspect fifty years from the same date, the difference would be striking indeed. Possibly, the designer has never seen it since its first formation; probably his plans, in regard to the distribution of trees, were only very inperfectly executed in the first planting; it may be assumed as almost certain, that his aims respecting the thinning of masses, the feathering of outlines, and the defining of groups, have been either neglected or imperfectly attained; but, meanwhile, nature has steadily pursued her course, and, from a variety of causes, which can be more readily imagined than wondered at, has most inadequately realized the fair ideal of the artist; and yet, the whole scenie effect is often held to be as justly ascribable to him, as some finished 
gem of a picture is attributable to a Claude or a Tumer. We fear that proper allowance is scldom made for this disadrantage on the part of the garlenartist. It was averred, for example, by Repton, that many of those clumps which brought no small share of obloquy on the style of Brown - a style sufficiently marked with other and inherent fiults - were intended by him to be thinned ont into groups; but in consequence of his intentions being forgotten or disregarded, were pernitted to remain and grow up into that undeniable deformity which awakened the bitter criticism ot Price and other's. In this, Bromn appears to have been made responsible for errors not his own. It is easy to see how other artists may suftic similar injustice. In short, by this means, the delicate finish of the scenic picture may never have been accorded, and so the desired effect, imagined with exquisite taste, and skillfully aimed at in the primary execution, may be entirely frustrated. And how are these natural defects of the art to be remedied? Only by repeated rerision. To stipulate for steh revision, as the privilege of the original artist, may be ineonsistent with the delicacy of a gentleman, while actually engaged in his profession; but in a work like the present, no delicacy should prevent the strong assertion of its necessity. Without doubt, to attain a degree of perlection, the artist should be occasionally recalled to revise lis work, and to correct the consequences of time by a few additional touches. Bnt the artist may cease to practice, and his works may long outlive him; to meet these contingenees, we should recommend that, in the case of any new parks and pleasure-grounds, or where axy considerable addition or alteration in them has 
been made, a general plan should be executed on paper, accompanied by sufficient memoranda, and kejt as a record of what had been originally, or subsequently, proposed and sanctioned. By this means, the designs, in their proper form, could be successively carried into effect. In visiting certain old parks and pleasure-grounds, bearing on their face the evidence of repented changes, we have often wished for a plan coëral with their formation, and some documentary tracings of the alterations which time and varying taste had wronght on them. If trees had the gift of speech, they could tell us many curious tales. Such authentic memorials would be most interesting in regard to the history, and instructive as to the practice, of the art.

The general plans which we have thus recommended as a record of original designs and successire changes, are not less necessary in the primary arrangement and laying-out of parks and pleasure-grounds. Those who have had the management of extensive and diversified operations, and have studied the means of effectually carrying them out, will not fail to appreciate their great ralne. We are aware that it is the custom of some amateurs, who busy themselres in landscapegardening, to sneer at plans as below the dignity and unworthy of the notice of a great artist. We must be allowed to say, that we hare generally found these great artists rather defective in that practical knowledge which wonld fully warrant them to give a decided opinion on the subject. The architect knows well the importance and the necessity of plans and specifications, in building the mansion-house, in which work many operations are to be carried on under a deputed 
superintendence, that wonld otherwise require his constant presence. So the landscape-gardener, who has examined grounds with such eare as to warrant his attempting their improvement in the way of decoration, can have little difficulty in making plans and specifications for the general arrangement of the place and for the particular execution of many of the details, such as may be put into the hands of competent individuals with the assurance that they will be duly executed without his continued attendance on the grounds. There are, horrever, things which must be done under his own eye, or at least must be frequently inspected by him during their progress. This remark holds especially true in the extending and remodeling of old places. The opening of views, the grouping of trees and shrubs, and some other nice operations, can be effected neither by plans nor by delegation. The improver ought, if possible, to give them the benefit of his personal direction; otherwise, he may find that, in his absence, a few trees - ay, a single tree, has been cut down, to the most serious injury of one of his best pictures. Eren in such cases, however, it is beneficial for the sake of the improvements as a whole, to have a general plan coustructed. Undoubtedly, when little time is allowed, the artist may at once stake out some hurried designs on the ground; and this he may do with less expense of thought and contrivince than the proper treatinent of the case demands, and with much less labor than is necessary to that minute survey of the locality which is required for the formation of a jlan upon paper; but the probability of his erring will, on that very account, be proportionally greater, 
and the likelihood of his directions being mistaken or forgotten may be regarded as amounting to certainty. In connection with this part of the subject, we take the liberty of remarking, that it is not advisable for gentlemen who intend to consult a landscape-gardener to engage in preparatory operations, for the purpose of clearing the way for hin. Such work is better left to the artist himself, and more particularly when he has to deal witl old places. In the improvement of existing park and pleasure-grounds, the operations have, perhaps, as close an analogy to sculpture as to painting. Give the improver a well-wooded country, with a surface sufficiently diversified, and he will cut out of it a park and pleasure-ground, just as a sculptor will ent a group out of a block of marble. But what would the sculptor say, were the stone-cutters in the quarry to insist on reducing his block to what they conceived might be an appropriate shape? Equally objectionable is preliminary interference with the proper work of the landscape-gardener. We once met with an afflictive case of this kind. A gentleman had been induced to prepare for our advent, by thinning out the trees and smoothing the ground in an old wood on the clrawing-room front of the house. He unfortunately allowed the operations to proceed in lis absence; and on his return home, which he had been obliged to leave for some months, he found several acres of grass, and, instead of the old wood, a few ragged, misshapen trees, little better than bare poles, stuck here and there over the surface. The reader will readily conceive the horror of the proprietor when he discovered that the leveling Goths had not contented themselves with smoothing the ground, but had 
also swept away trees which it would take a century to replace. It was with deep sympathy that we surreyed the scene of desolation, mingled with regret, that for the preservation of many elements of beauty which had, without doubt, existed, we had arrived nine months too late.

Note.-In whatever relates to the subject of this chapter, a natural taste, matured by cultivation, ancl year's of observation, is necessary in any one proposing to practice upon it. Neither the cultivation nor the observation required for the maturity of a proper taste in the laying-out and construction of parks, or other grounds, is to be acquirer from books alone. Nature itself, in all her moods and circumstances, should be closely studied. Among the professional "arts," tliat of "Landscape-gardening" should be the least artistic in its operations. It has to deal with nature alone, and is, in its true sense, but nature dirested of its prurient excesses, and modified into simplicity and beauty. Art, of itsclf, in the disposition of woods and waters, is poor, compared with nature, in clothing the carth with trees, and lighting it up with waters. The cultivation of the earth is art, so far as digging its surface, deposit of seeds, or setting of plants, are concerned; but in all that succeeds, nature is the only operator. Nature may bo guided and directed, but all the interference of art can add no beauty to shape or effect. The surfaces of ground may be modified; abrupt points, or banks, saay be softened; streams of water may be changed in their courses, and by their presence add new beau. ties to a chosen spot; but no territory thrown into fancifnl designs will produce an effect otherwise than 
repulsive to those of true taste and judgment. So with trees and shrubbery. Nature has given each variety its own chosen form, which no artificial aid will improve. The saw and the pruning-knife, to remove a superfluons branch, are all that need be required, to give them the highest possible expression; and what these will not do, is hardly worth attempting.

Art, in this relation, when deeply studied, is apt to degenerate into mannerism; and mannerism is always stift and ungraceful. No two spots of ground, or tracts of land, are exactly alike. In inproving them, their salient points should be ascertained. They should be placed in prominent relief, and their peculiar characteristics preserved. Such, even when repulsive at first view and considered by themselves alone, skillfully treated, may become the most agreeable objects in contrast or connection with other's of opposite character. This is all the art required - that of moulding and softening natural features into agreeable forms, and giving them agrecable expression. To accomplish this in the most acceptable manner, requires an enlarged and comprehensive scope, both of vision and imagination, embracing the whole as it will appear when perfected.

Note.-Our author has treated this part of his subject with good sense and judgment. There is nothing of the quack or charlatan about him, and no one can err in following his clear and direct sugrestions. Sir Walter Seott, whose true spirit and feeling he has strongly imbibed, was, in theory at least, one of the most aecomplished landscape-gardeners of the present century, and has left some of the best instructions in that line which it has been our fortune to consult. $\mathrm{He}$ had an 
exquisite eye for the sublime, the grand, the picturesque, and the beautiful in nature. He has delineated and interwoven them, with the highest effect, into his various writings, giving to them much of their striking effect and beanty; and to his essays on this subject we commend the scholar who is solicitous to learn in so interesting a subject.

To the American, working on American soil, and under an American sun, the practical labors of cloth- ing the ground with wood should be widely different from the teachings of British authors. The liumid climate of the British Isles will tolerate a far different treatment in plantations than in America. Sir IIenry Stuart, of Allanton Park, in Scotland, many years ago published an elaborate and interesting book upon giving immediate effect to park scenery, by transplanting large trees. It was read with much interest by many an American, and unfortunately followed in practice by some of them, with calamitous results our American climate being unfitted for such a system of transplanting as Sir Henry found so successful in Scotland. In all else were his instructions valuable.

It will doubtless be some years before our country will exhibit many striking evidences of skill and continued care in the cultivation of parks and pleasuregrounds. We are too unstable in our pursuits, and our landed tenures too fitful in possession, sare in isolated cases, to show those striking features of interest which belong to the more permanent estates of European landholders. Yet much may be done, in a comparatively short time, by choosing a firorable spot and treating it with taste and judgment. The very improvement of such places, properly appreciated, will 
impress themselves in the affections of their proprietors, and induce them to retain them as heir-looms to their posterity. Without a motive of this kind, our progress must be slow and fitful, dictated by fashion or caprice. Taste and refinement may seek such objects, and such pursuits; but without a proper education in those who are heirs to such possessions, and a lore and veneration for them, they become the shuttlecock of wealth, and a resort only of such as lead or follow in the train of fashiou. In this relation, parks and pleasure-grounds entail enlarged expense and consequent vexation in the occupation; and, after a short-lived possession, are whistled away like any other bauble whose annoyances largely overbalance their adrantages; and all this from the want of a proper understanding of their true purposes.-ED. 
THE ARBORETCM.

\section{CHAPTER XIII.}

THE ARBORETUM.

Definition - Recent Introduetion - General Idea of Arrangement.

Secr. 1. Scientific Treatment of the Arboretum-Introductory Remarks - Dr. Lindley's Classification of the Natural Orders - Explanations - Synopsis of Orders and Genera - Application of Principles - Transference of the System to the Ground.

Sect. II. Decorative Treatment of the Arhoretum - Object in View Enploynent of Larger Trees - Lawns - Surfaces Planted - Erergreens - Arboretums Attached to Prirate Residences-Sites in Yleasure-grounds.

As arboretum, as now planted, may be defined to be a collection of hardy trees and shrubs, arranged according to their natural affinities. The different species and varieties are placed together under the genera, orders, and natural groups to which they belong; and by this means, their resemblances and differences are more easily recognized and distinguished from their being blought into proximity - than they mould be in any promiscuous distribution. The aftinities to which we have alluded are best preserved when the arrangement adopted is that of some one of the botanical systems constructed on the principle of Natural Orders; and fortunately, these, too, exhibit most conspicuously those more extermal and prominent characters which are apt to strike the eye of even a casual observer. We hare thus a happy union of the 
scientific and the popular elements. Such collections of trees and shrubs are extremely interesting to the botanist, as presenting to his outward eye, in material and living presence, the various forms which in their more refined relations enter into his abstract and recundite arrangements; but they also possess much interest to the general student of nature, exhibiting, as they do, the number and diverse characters of the trees and underwood which tenant the mighty forests, the tangled brakes, the stunted scrubs, and barren heaths, that cover the valleys, plains, and mountains of the colder regions of the globe.

Arboretums are only of recent introduction as decorative accompaniments to country residences and public gardens. For a long period, indeed, a considerable variety of trees and shrubs have been cultivated in parks and pleasure-grounds; and flowering shrubs, in particular, have always been favorite materials of ornament in flower-gardens. But scientific classifications of these forms of vegetable life received little attention previous to the formation, in 1823, of the arboretum in the garden belonging to the London Horticultural Society, at Turnham Green. Since that great and meritorious collection attracted the notice which was due to it, many similar, though generally less extensive, arboretums have been formed; so that now no moderate sized country residence or public park and garden can be considered complete linless something of the kind enters into their arrangements. Undoubt edly the finest arboretum now in existence, at least so far as we are aware, is that in the Royal Gardens at Kew, though even there the limitation of the space to which it is restricted leaves some reasons for regret, 
which, however, we trust will be removed by the national liberality as applied and regulated by the Commissioners of Woods and Forests.

In order to realize its aims and adequately to fulfill its main purposes, an arboretum requires a botanical arrangement; and that commonly adopted has been the Natural System of the celebrated De Candolle. Such is the method followed lyy Loudon in his great work, "The Arboretum Britannicm," and also in lis abridgment of it in his "Eneyclopedia of Trees and Shrubs." In this arrangement the Natural Orders are thrown into three great divisions, which; in the actual construction of an arboretum, we have fund to be not a little unwieldy and unmanageable. Te very greatly prefer the classified Alliances of orders giren by Dr. Lindley in his "Vegetable Kingdom," as allowing a more unfettered distribution of the materials, and therefore yielding more abundant opportunities for the eliciting of picturesque effects than any other system we have yet studied. "We have no doubt that a careful examination of $\mathrm{Dr}$. Lindley's valuable work, and a practical aequaintance with the subject, will lead most impartial inquirers to the same conclusion. At the same time the reader is reminded that any botanical arrangement of living regetables can be only an approximation of a very fragmentary character. Trees and shrubs compose only a part of the system of nature, though happily some of the groups are very complete, eren when made up of the hardy species. It is evident that the linear arrangements, such as those to be found in catalogues of names, are not to be entertained as satisfactory. The distribution is necessarily made on superficial space, that is, on space of two 
dimensions, as it is technically called. Auy one who studies the interesting indications of "position," appended by Dr. Lindley to each of his natural orders, will readily perceive the difficulties which exist in this quarter. Some hare thought that a perfect coördination of affinities can be made only on space of three dimensions, as, for example, in the manner the stars are distributed in the firmament. We can not pursue this subject, which would lead ns into the most profound depths of the science of botany; and indeed we need not enter into it, as in the actual formation of an arboretum we are compelled to roork on surfices. Let it be remembered then, that both on accomnt of the fragmentary nature of the materials employed, and their numerous and intertwining relations, as well as the superficial form of the space operated on, the ar. rangement can only be an approximation when considered as a whole.

Sectr. I. - Sciextifre Treatuent of the Arboretcyi.

In this section it is proposed to give a sketch of the Natural System of botany as it may be embodied in a living collection of hardy trees and shrubs. This, we are aware, may appear something different firm, and discordant with, the other subjects treated in this volume; nerertheless, on mature cunsideration, we feel constrained either to present it to our reader's as absolutely necessary to render the remainder of on remarks intelligible, or to omit the interesting subject of the arboretum altogether. We might as well discuss the topography of a country without a map, as 
describe an arboretum, or give directions for its formation, withont reference to the scientific principles on which its arrangenent is based. We trust the reader will not be repelled by the terminology, which it must be owned lias a somewhat formidable look, but which no one has ever imagined could be materially simplified, and at the same time retain its exactness. Even the unbotanical reader, by running lis eye along tho English names, will be able to form a pretty correct conception of the materials of which an arboretum is composed. Persons about to undertake the execution of such work will find in the following synopsis the general outlines of an arrangement which they may modify or abridge according to the special objects they have in view. To those who may think our labor useless, we shall only say that we should have considered a much slighter sketch a boon the first time we were called to lay out an arboretum.

As already stated, we prefer Dr. Lindley's arrangement of the natural orders, as most suited for the effective adornment of an arboretum; accordingly we have borrowed the following syllabus of classification, with some very slight modifications of the genera, from the second edition of his "Vegetable Kingdom." The reader who desires fuller information regarding the alliances, orders, ${ }^{\text {and }}$ genera, will find it amply supplied in that admirable work. Of course, in regard to the species, we must have recourse to books containing detailed descriptions, or to the larger catalognes which have been published by Loudon and others. Loudon's "Arboretum Britannicum" and "Encyclopædia of Trees and Shrubs" may also be consulted with advantage, or rather may be regarded as means 
essential to success. We refer throughout to his Natural Orders, exhibited in his "Encyclopædia of Trees and Shrubs," as affording detailed descriptions of the species. Any hardy plants recently introduced may easily be inserted into their proper places as soon as their respective genera and orders are ascertained.

In connection with the genera we have indicated whether the individuals are trees or shrubs, whether they are deciduous or evergreen, or whether they are partly the one and the other. When the genus is not generally hardy, it is marked as sub-hardy; and when there are hardy and sub-hardy species in cultivation, this fact also is marked. Where no such distinction is made, the plants may be considered as hardy in the average climate of the United Kingdom. The heights specified must be regarded as the general altitude of the genus rather than the stature of the individual species; the latter being often extremely varied, in some cases ranging toward the higher, in others to. ward the lower limit. The numbers of species and varieties are sometimes only approximative. $\mathrm{Mr}$. Loudon, for example, describes 170 willows, while we have described only 100 ; and even that lower number it would probably be difticult to procure. We believe that there are about 1500 species and 1000 botanical varieties of hardy trees and shrubs-exclusive of what may be called florists' varieties of roses, azaleas, etc. - cultivated in our well-appointed murseries. Of course a selection of these is sometimes all that the extent of the ground to be occupied will permit to be employed.

As many of Dr. Lindley's alliances and orders do not contain plants which are ligneous and hardy, they 
are of course omitted. For the sake of convenience we have marked the allianees and orders, selected for our present purpose, with running numbers, beginning in both eases from unity; but to prevent confusion we have quoted the numeration of "The Vegetable Kingdom" throughout, giving the numbers of its classes and allianees within parentheses, thus: for a class (V.K. IT.,) and for an allianee (V.K. 16.) $\mathrm{W}^{\top} \mathrm{e}$ beg the reader's attention to the following

\section{I.IST OF ABBREVIATIONS.}

D. Deciduous ; denoting plants shedding their leaves in autumn.

E. Evergreen.

SE. Sub-Erergreen ; applied to plants retaining part of their foliage throutgh winter.

T. Tree.

S. Shrub.

Cl. Climber - a plant climbing or twining, and requiring or finding support.

Tr. Trailing - applied to plants creeping or lying on the ground.

h. Hardy; sh. sub-hardy, i. e. hardy in some places but not in others. Sp. Species; $\mathbf{v}$. botanical variety.

SYNOPSIS

OF THE SATLRAL ORDERS AND GEXERA OF PLANTS THHCH MAY BE EMPLOYED IN FORMING AN ARBORETLY.

Class ENDOGENS. (V. K. IV.)

Alitasce 1. Liliales. (V. K. 16.)

Ord. 1. Liniace.e. Lilyzoorts. (Lindl. 62; Loud. 80.)

Yucca. Adam's Needle. E. S. sh. 4-10 ft. Sp. $10 ;$ จ. 2.

Ruscus. Butcher's Broom. E. S. 2-3 ft. Sp. 4 ; v. 3.

Borya. D. S. 5-e ft. Sp. 3.

Class DICTYOGENS. (V. K. V.)

Alliance 2. DICT YOGENS. (Lindl.)

Ord. 2. Smizace.e. Sarsaparillas. Lindl. 69 ; Loud. 79.)

Smilax. E. D. Cl. Sp. 16. 


\section{Class GYMNOGENS. (V. K. VI.)}

Alliaxce 3. GYMNogens. (Lindl.)

Ord. 3. Prisees. Conifers. (Lindl. 74 ; Loud. 77.)

Sibb-ord.1. Agiete.e. Fïrs.

Pinus. Pine. E. T. S. $10-100 \mathrm{ft}$. Sp. 67 ; v. 27.

Abies. Fir and Cedar. E. D. T. S. 10-200 ft. Sp. 40 ; จ. 29. Picea. Larix. Cedrus.

Araucaria. Chili Pine. E. T. $100 \mathrm{ft}$. Sp. I.

Cunninghamia. E. T. sh. Sp. 1.

Sequoia. E. T. h. sl. $50-200 \mathrm{ft}$. Sp. 2.

Sub-ord. 2. CUTressee.

Juniperus. Juniper. E. T. S.h. sl. 1-40 ft. Sp. 31 ; v. 12.

Callitris. E. T. sh. $30-40 \mathrm{ft}$. Sp. 1.

Libocedrus. Chili Arborrita. E. T. h. sh. $30-70$ fr. Sp. 3.

Biota. Chinese Arbortite. E. T. S.h. sh. 15-50 ft. Sp. 5 ; จ. 4.

Thuia. Arborritc. E. T. S. $15-40$ ft. Sp. 3.

Cupressus. Cypress. E. T. S. h. sh. 15-40. Sp. 10 ; v. 2.

Chamæcyparis. White Cedar. E. T. 10-30 ft. Sp. 5; v. 3.

Taxodium. Deciduous Cypress. D.T.h. sh. 20-70 ft. Sp. 4.

Glyptostrobus. E. S. h. sh. $10-15$ ft. Sp. 2.

Cryptomeria. Japan Cedar. E. T. h. sh. 15-50 ft. Sp. 2.

Fitzroya. Fitzroy Yew. E. T. 20-100 ft. Sp. 1.

Sax-Gothea. Prince Albert's Yew. E. T. 30 ft. Sp. 1.

Ord. 4. TAXACE.s. Taxads. (Lindl. 75 ; Loud. 76.)

Taxus. Yezo. E. T. $10-40 \mathrm{ft} . \quad$ Sp. 3 ; v. 9.

Podocarpus. Lobb's Yezo. E. T. $40 \mathrm{ft}$. Sp. 1.

Torreya. Torrey's Yelo. E. T. 20-40 ft. Sp. 3.

Cephalotaxus. Japanese Yero. E. T. 20-30 ft. Sp. 5 .

Salisburia. Maiden-hair Tree. D. T. 1:-50. Sp.1.

\section{Class EXOGENS. (V. K. VII.)}

\section{Alimaice 4. AMEntales. (V. K. 18.)}

Ord. 5. Casuarinacee. Tecficoods. (Lindl, 77.)

Casuarina. E. S. sh. W. 9-12 ft. Sp. 1.

Ord. 6. Betllacee. Lirchuorts. (Lindl. 78; Loud. 69.)

Betula. Eirch. D. T. S. 3-60 ft. Sp. 12; v. 11 .

Alnus. Aldcr. D. T. S. $6-60 \mathrm{ft}$. Sp. $11 ;$ v. 10.

Ord. 7. Altingiace.e. Liquidambar. (Liudl. 79 ; Loud. 73.)

Liquidambar. D. T. 30-40 ft. Sp. 2.

Ord. 8. Salicace.e. Willom rorts. (Lindl. 80 ; Loud. 68.) 
Salix. Willow. D. T. S. 3-70 ft. Sp. 100 ; v. 15.

Populus. Poplar. D. T. $30-100 \mathrm{ft}$. Sp. 18 ; v. 15.

Ord. 9. Mrricacke. Galeworls. (Lindl. 81 ; Loud. 74.)

Myrica. Galc. D. E. S. 3-12 ft. Sp. 2; v. 1.

Comptonia. D. S. 3-4 ft. Sp 1.

Ord. 10. Elatgracr.e. Oleasters. (Lindl. 82 ; Loud. 62.)

Shepherdia. D. T. S. $\varepsilon-20 \mathrm{ft} . \quad$ Sp. 2.

Hippophac̈. D. T. S. 6-16 ft. Sp. 2; v 1 .

Elæagnus. D. T.S. $10-20 \mathrm{ft}$. Sp. 7 ; v. 3.

Alliaxce 5. UR'TICALES. (V. K. 19.)

Ord. 11. Horacee. (Lindl. 87 ; Loud. 65.)

Morus. Alulberry. D. T. $20-30 \mathrm{ft} . \quad$ Sp. $4 ; \nabla 13$

Maclura. D. S. 6-10 ft. Sp. I.

Ficus. Fig. D. T.S. $5-20 \mathrm{ft}$. Sp. I.

Ord. 12. Plataxace.c. (Lind1. 89 ; Loud. 72.)

Platanus. Piane. D. T. S. h. 60-\$0 ft. Sp. 4 ; v. 3.

Alliaice 6. EUPhORBIALES. (V. I. 20.)

Ord. 13. Etpnordiace.e. (Lindl. 90 ; Loud. 64.)

Buxus. Eox. E. S. :-15 ft. Sp. 2; v. 18.

Ord. 14. Empetnacz.e. Crouberries. (LindI 93; Loud 78.)

Empetrum. Crouberry. E. S. 6-12 in. Sp. 2; จ. 8.

Alliace 7. QUERNALES. (V. K. 21.)

Ord. 15. Cosylace.e Mastuorts. (Lindl. 95; Loud. 70.)

Carpinus. Hornbeam. D. T. $10-70 \mathrm{ft}$. Sp. 3; v. 2.

Ostrya. Hop-hornbeain. D. T. 15-40 ft. Sp. 2.

Corylus. HIazd. D. T. S. $5-50 \mathrm{ft}$ Sp. 4 ; พ. 8.

Fagus. Ecceh. D. E. T. 20-80 ft. Sp. 3; v. 6.

Castanea. Spanish Chestnut. D. T. S. $2-\$ 0 \mathrm{ft}$. Sp. 2 ; r. 6.

Quercus. Oak, Ilex. D. E. T. S. $15-103$ ft. Sp. $36 ;$ v. 48.

Ord. 16. Juglaxpacre. Juglands. (Lind!. 96 ; Loud. 67.)

Juglans. Walned. D. T. 30-60 ft. Sp. 4 ; v. 4.

Carya. Hickory. D. T. $60-80$ ft. Sp. 8; v. 2.

Pterocarya. D. T. 20-10 ft. Sp. 1.

Allince. 8. GARRYALES. (V. K. 22.)

Ord. 17. Garnyacre. Garryads. (Lindl. 97 ; Loud. 71.)

Garrya. E. S. 6-10 ft. Sp. 2 .

AlLiaxce 9. MENISPERMIALES. (V. K. 23.)

Ord. 18. Mznispermacz.e. Menispermads. (Lind]. 104; Lond. 5.)

Menispermum. Woonseed. D. Cl. 8-10 ft. Sp. 2.

Cocculus. E. Tr. 1-1/2 feet. Sp. 1.

Allasce 10. Violales. (V. K. 26.)

Ord. 19. Flacovatuce.e. Bixadi. (Lindl. 110 ; Lothd. 23.) 
Azara. E. S. W. Sp. 1.

Owd. 20. Tamaricaces. (Lindl. 118; Loud. 29.)

Tamarix. Tanarisk. D. S. 5-15 ft. Sp. 2.

AllaxeE 11. CISTALES. (V. K. 27.)

Ord. 21. Cistacke. (Lindl. 122 ; Loud. 8.)

Cistus. Rock Rosc. SE. S. sh. . 2-8 ft. Sp. 12.

Helianthemun. Sun Rose. SE. Tr. 6-12 in. Sp. 8; ז. 20.

Ord. 22. Brassicacee. Crucifers. (Lindl. 123; Loud. 7.)

Vella. Cress Rocket. SE. S. 2-4 ft. Sp. 1.

Aluiace 12. MALVALES. (V.K. 28.)

Ord. 23. Malvace.e. Mallowuorts. (Lindl. 130 : Loud. 9.)

Hibiscus. Althea Frutcx. D. S. 3-6 ft. Sp. 1; v. 13.

Sida. D. S. 6-8 ft. Sp. 1.

Ord. 24. T'utraces. Lindenblgons. (Lindl. 131 ; Loud. 10.)

'ilia. Lime T'rec. D. T. 20-90 ft. Sp. 3; v. 11.

Corchorus. 1). S. 6-10 ft. Sp. 1.

Allianow 13. SAPINDALES. (V. K. 29.)

Ord. 25. Ponyalaces. Milkworts. (Lindl. 133 ; Loud. 58.)

Polygualiw Milkwort. E. S. 6 in. Sp. 1.

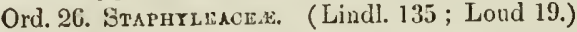

Staphinglea. Eladder-nut. D. S. 6-10 ft. Sp. 2.

Ord. 27. Sarindacke. Soapworts. (Lindl. 136 ; Loud. 13.)

Issculus. Horse Chestmut sp. 1). T. 20-60 ft. Sp.6; v. 4. Pavia. Horso Chestnut sp. D. T.S. $4-10$ ft. Sp. 8 ; w 3 .

Kølreuteria. D. T. 30-10 it. Sp). 1.

Ord. 28. ACrracre. Maples. (Lindi. 138 ; Loud. i3.)

Acer. Maplc, Sycamorc. D. T. 20-80 lt. Sp. 20; v. 17.

Negundo. Box-elder. 1. 'T'. 30-50 ft. Sp. 1 ; v. 2.

Alutance 14. GUTTIFERALES. (T. K. 30.)

Ord. 29. Tebxstremaces. Theads. (Lindl. 142; Loud. 11.)

Balachodendron. D. T. 6-12 ft. Sp. 1.

Stuartia. D. S. 6-10 1. Sp. 1.

Gordonia. D. SE. S. 6-10 ft. Sp. 2.

Ord. 30. HYpericace.t. Tutsans. (Lindl. 116; Loud. 12.)

Hypericum. St. John's Worts. D. SE. S. 1-5 ft. Sp. 9; v. 2.

Alurave 15. RANALES. (V. K. 32.)

Ord. 21. Mignoliacee. Magnolouls. (Lindl. 151 ; Loud. 3.)

Magnolia. D. E. T. S. h. sh. 3-50 ft. Sp. 10; v. 10.

Liriodendron. Tulip-trce. D. T. $40-80 \mathrm{ft}$. Sp. 1; r. 1 .

Ord. 32. Axorace. Anonads. (Lindl. 142 ; Loud. 4.)

Uvaria. Asiminia (syn.). D. S. 6-10 ft. Sp. 1.

Ord. 33. Ranuncelace.e. Ranunculoids. (Lindl. 141 ; Loud. 1.) 
Clematis. Virgin's Eoucr. D. E. Cl. Sp. 16; v. 18.

Atragene. D. Cl. Sp. 3.

Pronia. Pcony. D. S. $3-7 \mathrm{ft}$. Sp. 1 ; v. 6.

Xanthorrhiza. Icilouroot. D. S. $2-3 \mathrm{ft}$. Sp. 1.

ALLAANCE 16. BERBERALKS. (V. K. 33.)

Ord. 34. Benberidacex. Ecrbcrids. (Lindl. 153; Loud 6.)

Berberis. Eerbcrry. D. E. S. 6-15 ft. Sp. 20 ; $v 11$.

Mahonia. E. S. 1-7 fto Sp. fi.

Ord. 35. Tracese Irincworls. (Lindl. 140 ; Loud. 16.)

Vitis. Vine. D. Cl. Sp. 5 ; r. 3.

Cissus. Ampclopsis (syn.). D. Cl. Sp. 1.

Ord. 36. Pitrospozace. Pittosporads. (Lindl. 141.)

Pittosporum. E. S. W. E-10 ft. S 1 .

Billardiera. W. Sp. 1.

Sollya. S. W. 8-10 ft. Sp. 1.

ALLIANCE 17. ERICALES. (V. K. 34.)

Ord. 37. Enicacex. Heathworts. (Lindl. 169; Loud. 13.)

(1.) Ericer.

Erica Heath. E. S. $1 / 2-6$ ft. Sp. $12 ;$ r. 15.

Calluna. Ling. E. S. 1-3 ft. Sp. 1 ; r. 12.

Menziesia. Bryanthus (syn.) E. S. 1/2-2 fh. Sp. 3.

Andromeda. D. E. S. $1 / 2-10 \mathrm{ft}$. Sp. $16 ;$ v. 12 .

Lyonia. D. E. S. $225 \mathrm{ft}$. Sp. 10.

Clethra D. S. 3-4 ft. Sp. 5 ; v. 1.

Epegæa. E. Tr. Sp. 2.

Gaultheria. E. S. 1-3 ft. Sp. 3.

Pernetya. E. S. 2-6 ft. Sp. 4.

Arbutus. Strazberry-tree. E.S.h.sh. 3-25 ft. Sp. 10; т. 6. Arctostaphylos. Bear-berry. E. Tr. Sp. 3.

(2.) Rhododendrea.

Azalea. D. E. S. $1 / 2-6$ ft. Sp. $14 ;$ г. 60.

Kalmia. E. S. $1-5$ ft. Sp. 35 ; т. 7.

Rhododendron. E. D. S. h. sl.. 1-15 ft. Sp. 35 ; r. 60.

Rhodora. D. S. $2-4 \mathrm{ft}$. Sp. 1.

Leiophyllun. D. S. 1/2-1. Sp. 1.

Ledum. E. S. $2-1 \mathrm{ft}$. Sp. 5.

ALLIANCE 13. RUTALES. (V. K. 35.)

Ord. 38. ANacardiace.s. Terelinths. (Lindl. 174; Loud. 24.)

Pistacia. E. D. I. sh. Pistachia-tree. 10-20 ft. Sp. 3; v. 5.

Duraua. E.S. W. Sp. 3.

Rhus. Sumachs. D. T. S. Cl. 4-20 ft. Sp. 8; r. 10. 14 
Ord. 39. Хaxtnoxylackx. Xinthoxyls. (Lindl. 177; Loud. 17.) Xanthoxylon. Toothache-tree. D.S. 10-12 ft. Sp. 2; v. 1. Ptelea, D. S. 6-10 ft. Sp. 2 ; v. 2.

Ailanthus. Tike Ailanto. D. T. sh. $15-50 \mathrm{ft}$. Sp. 1.

Ord. 40. Ochyace. Coriarica (syn. Loud.) (Lindl. 178; Loud. 18.)

Coriaria. D. S. $2-3 \mathrm{ft}$. Sp. 1 .

ALLiates 19. SILENALES. (V. K. 37.)

Ord. 41. Poltgoxaces. Buchicheats. (Liudl. 191 ; Loud. 58.)

Atraphaxis. SE. S. 1/2-3 ft. Sp. 1 .

Tragopyrum. SE. S. 1-2 ft. Sp. 3.

C:lligonum. E. S. 2-3 ft. Sp. 1.

Altiaxoe 20. CHenopodales. (V. K. 38.)

Ord. 4.. Chexopodiaces. Chenopods. (Lindl. 195; Loud. 57.)

Atriplex. Orache. SE. S. 4-6 ft. Sp. 2.

Diotis. D. S. $2-3 \mathrm{ft}$. Sp. 1 .

Cheuopodium. Goose-foot. D. S. 2-3 ft. Sp. 2.

ALLiace 21. DAl'HNALES. (V. K. 41.)

Orl. 43. Thymelaces. Daphnods. (Lindl. 203 ; Loud. 60.)

Daphne. Sparge Laurel. E. D. S. h. sh. 1-4 ft. Sp. 14 ; v. 4.

Mezereum. Mezereon. D. S. 2-6 ft. Sp. 1; v. 2.

Dirca. Leatherzood. D. S. 2-1 ft. Sp. 1.

Ord. 44. Latrace.E. Laurcls. (Lindl. 205; Loud. 59.)

Laurus. Siccet Bay. E. S. $5-20$ ft. Sp. 1 ; v. 6.

AlLiatcz 22. ROSAlES. (V. K. 42.)

Ord. 45. Calycanthace.e. Calycanths. (Lindl. 207; Loud. 27.)

Calycanthus. Allspice. D. S. 3-S ft. Sp. 4 ; v. 9.

Chimonantlus. Winter-flowoer. D. S. W. 4-6 ft. Sp. 8; v. 3.

Ord. 46. FABAor.x. Leguminous Plants. (Lindl. 209 ; Loud. 25.)

Piptanthus. SE. S. sh. W. 6-8 ft. Sp. 1.

Thermopsis. SE. S. sl. W. 6-8 ft. Sp. 1.

Adenocarpus. D. S. $2-10 \mathrm{ft} . \mathrm{Sp} .5$.

Ulex. Whin, Furze. E. S. $2-10$ ft. Sp. 4 ; v. 1.

Spartium. Spanish Broom. E. S. 6-10 ft. Sp. 1 ; v. 2.

Genista. Broom. D. SE. S. Tr. 1-6 ft. Sp. 24; v. 8.

Cytisus. Cytians, Laburnum. D. SE. T. S. Tr. 1-30 ft. Sp. 27 ; v. 9.

Ononis. Rest-harrovo. D. S. 2-10 ft. Sp. 2.

Indigofera. Indign. D. S. W. Sp. 2.

Amorpha. Easturd Indigo. D. S. 2-10 ft. Sp. 6; จ. 4.

Wisteria. D. Cl. W. Sp. 1.

Robinia. Locust-trce. D. T. S. 6-60 ft. Sp. 8; v. 19 
Sutherlandia. D. S. 5-8 ft. Sp. 1.

Colntea. Eladder-senna. D. S. 3-12 ft. Sp. 5.

Caragana. Silerian Pea-tree. D. T. S. 1-20 ft. Sp. 13; r. 4.

Halimodendrou. Salt-tree. D. S. 3-6 ft. Sp. 2; v. 3.

Astragalus. Milk-rctch. D. S. 6-12 in. Sp. 1.

Coronilla. Scorpion-senna. D. S. 3-10 ft. Sp. 4.

Edwardsia. E. S. W. Sp. 1.

Sophora. D. T. $30-50 \mathrm{ft}$. Sp. 2.

Virgilia. D. T. S. $10-30 \mathrm{ft} . \quad \mathrm{Sp} .2 ;$ v. 4.

Gymuocladus. D. T. $10-30 \mathrm{ft.}$ Sp. $2 ;$ r. 4.

Cercis. Judas-tree. D. T. S. $10-30 \mathrm{ft}$. Sp. 2 ; r. 4.

Gleditschia. D. T. $15-50$ ft. Sp. 6 ; r. 7.

Acacia. D. S. sh. Sp. 3.

Ord. 47. Detrace.e. Almondworts. (Lindl. 210; Loud. 2G.)

Amygdalus. Almond. D. T. S. $2-20$ ft. Sp. $4 ;$ v. 9.

Persica. Peach. D. T. W. Sp. 2 ; v. 8.

Prunus. Plum. D. T. S. 3-30 ft. Sp. 9 ; r. 13.

Armeniaca. Apricot. D. T. W. Sp. 4 ; r. 4.

Cerasus. Cherry and Laurels. D. E. T. S. 3-60 ft. Sp. 30; จ. 18.

Ord. 48. Pomaces. Appleveorts. (Lindl. 211; Loud. 26.)

Cydonia. Quince. D. T. S. 5-20 ft. Sp. 3; v. 5.

Pyrus. Pear, Apple. D. T. S. 4-60 ft. Sp. 42; v. 29.

Aria. Malus. Sorbus.

Hespilus. Medlar. D. T. 10-20 ft. Sp. 2 ; v. 4.

Amelanchier. D. T. $15-30$ ft. Sp. 5 ; v. 3.

Cotoneaster. D. E. SE. S. Tr. $2-10$ ft. Sp. $10 ;$ r. 5.

Photinia. E. T.h. sl. 15-20 ft. Sp. 4.

Cratægus. Hauthorn. D. E. T. S. $4-30$ ft. Sp. 30 ; r. 52.

Stranræesia. E. S. W. 10-15 ft. Sp. 1.

Ord. 49. Rosace.f. Rosercorts. (Lindl. 213; Loud. 26.)

Rosa. Rose. D. E. S. Cl. 1-20 ft. Sp. 63; v. 35.

Potentilla. Cinquefuil. SE. S. 1-1 ft. Sp. $3 ;$ r. 2.

Rubus. Bramble, Rosplerry. D. S. T. 2-10 ft. Sp. 13; r. 13.

Purshia. D. S. sh. 2-3 ft. Sp. 1.

Dryas. E.T. 6 in. Sp. 1.

Kerrea. D. S. $2-3 \mathrm{ft} . \mathrm{Sp} .1$.

Spirea. Queen of the meadors. D.S. h. sh. 2-10 ft. Sp. 26 ; v. 4.

Alliasce 23. SAXIFRAGALES. (V. K. 43.)

Ord. 50. Hydrasgeanes. (Lindl. 215; Loud. 34.)

Hydrangea. D. S. sh. 3-6 ft. Sp. $6 ;$ v. 1. 
Alujaroe 24. RHAMNALES. (V. K. 44.)

Ord. 51. Ulmaсe.e. Elmworts. (Lindl. 221; Loud. 66.)

Celtis. Nettle-tree. D. T. 15-40 ft. Sp. 9; v. 2.

Planera. D. T. $20-60$ ft. Sp. 12 ; г. 1.

Ulmus. Elm-tree. D. T. $40-80$ ft. Sp. $12 ;$ v. 41 .

Ord. 52. RhaMryaces. Rhamnads. (Lindl. 222; Loud. 22.)

Paliurus, Christ's thorn. D. T. S. 10-20 ft. Sp. 2.

Zizyphus. D. S. 5-10 ft. Sp. 3.

Rhamnus. Buckthorn. D. E. T. S. 2-20 ft. Sp. 16; ซ. 6.

Ceanothus. D. E. S. h. sh. 4-6 ft. Sp. 4.

BerAsemia. D. Cl. 8-10 ft. Sp. 1.

Colletia. D. S. 3-4 ft. Sp. 1.

Ord. 53. Celastrace.e. Spindle-trees. (Lindl. 225 ; Loud. 20.)

Euonymus. Spindle-tree. D. SE. T. S.h. sh. 6-30 ft. Sp.7.

Celastrus. Staff-tree. D. Cl. 12-20 ft. Sp. 1.

Hartogia. E. S. 1-2 ft. Sp. 1.

Myginda. E. S. 3-4 ft. Sp. 1.

Ord. 54. Sapotace.. Sapotads. (Lindl. 227; Loud. 46.)

Árgania. E. S. W. Sp. 1.

Bumelia. SE. T. S. h. sh. 8-15 ft. Sp. 5.

Ord. 55. Strracace.e. Storaxioorts. (Lindl. 228; Loud. 44, 45.)

Styrax. D. S. 4-10 ft. Sp. 4.

Halesia. Snowdrop-tree. D. T. 10-30 ft. Sp. 3 .

ALLIANOE 25. GENTIANALES. (V. K. 45.)

Ord. 56. Eвехасе.E. Elenads. (Lindl. 229 ; Loud. 47.)

Dyospyrus. Date-plum. D. T. $20-30$ ft. Sp. 4 ; v. 2.

Ord. 57. AqUTFOLIAOE.E. Hollyzoorts. (Lindl. 230 ; Loud. 21.)

Ilex. Holly. E. T. S. $10-40$ ft. Sp. 12 ; r. 24.

Prinos. Winter-berry. D. E. S. 5-10 ft. Sp. 7.

Nemopanthes. D. S. $3-5 \mathrm{ft}$ Sp. 2 ; г. 6.

Ord. 58. Apoćrxacee. Dogbanes. (Lindl. 231 ; Loud. 50.)

Vinca. Perizoinkle. E. S. 1-2 ft. Sp. 1; v. 6.

$\triangle$ LIANCE 26. SOLANALES. (V. K. 46.)

Ord. 59. Oleace.s. Olixetcorts. (Lindl. 237 ; Loud. 48.)

Sub-ord. 1. OІ火火..

Chionanthus. Fringe-tree. D. S. 5-10 ft. Sp. 1; v. 3.

Olea. Olire. E. S. W. Sp. 1.

Phillyrea. E. T. S. 5-30 ft. Sp. 9.

Ligustrum. Privet. E. D. S. 6-12 ft. Sp. 3; v. 6.

Sub-ord. 2. Fratine.e.

Fraxinus. Ash. D. T. $30-100 \mathrm{ft} . \quad$ Sp. 20 ; v. 24

Ornus. Flowering Ash. D. T. 20-40 ft. Sp. 4. 
Fontanesia. SE. S. 8-12 ft. Sp. 1.

Syriuga. Lilae. D. S. 6-I 4 ft. Sp. 4 ; v. 8.

Forsythia. D. S. 8-10 ft. Sp. 1.

Ord. 60. Solaxice.e. Nightshades. (Lindl. 238; Loud. 53.)

Fabiana. E. S. W. 8-10 ft. Sp. 1.

Solanum. Nightshade. SE. Cl. 20-30 ft. Sp. 1.

Atropa. Deadly Nightshade. D. Cl. 6-8 ft.' Sp. 1.

Grabowskia. D. S. 6-8 ft. Sp. 1.

Lycium. Box-tharn. D. Cl. G-30 ft. Sp. 6 .

Ord. 61. Asclepiadaces. Asclepiads. (Lindl. 229; Loud. 51.)

Periploca. Virginian Silk. D. Cl. Sp. 1.

Alliance 27. ECHIALES. (V. K. 48.)

Ord. 62. JasmivaCEE. Jasimineworts. (Lindl. 249 ; Loud. A9.)

Jasminum. Jasmine. SE. S. 6-12 ft. Sp. 7 ; จ. 3.

Ord. 63. Lamaces. Labiates. (Lindl. 255 ; Loud. 55.)

Lavandula. Larender. E. S. 2-1 ft. Sp. 1.

Rosmarinus. Rosemary. E. S. 3-5 ft. Sp. 1.

Phlomis. E. S. 4-5 ft. Sp. 1 .

Ord. 64. Verbevace.e. Verbens. (Lindl. 256 ; Loud. 56.)

Vitex. Chaste-tree. D. S. 6-8 ft. Sp. 3; v. 1

Ord. 65. Mroporaces. Myoporads. (Lindl. 257.)

Myoporum. E. S. sh. 1-3 ft. Sp. 1.

Alliance 28. BIGNONIALES. (V. K. 49.)

Ord. 66. B1gronlaces. Bignoniads. (Lindl. 262 ; Loud. 52.)

Bignonia. Trumpet-flower. D. S. Cl. W. Sp. 1.

Tccorna. D. Cl. Sp. 2

Catalpa. D. T. h. sh. Sp. 1.

Ord. 67. Schrophulariacex. Figroorts. (Lindl. 264 ; Loud. 54.)

Maurandia. S. E. Cl. W. Sp. 1.

Pawlownia. D. T. sh. 20-40 ft. Sp. 1 .

Buddlea. D. S. \&-12 ft. Sp. 1.

Allance 29. CAMIPANALES. (V. K. 50.)

Ord. 68. Asteraces. Composites. (Lindl. 273 ; Loud. 42.)

Aster. Stanoort. D. S. sl. 4-5 ft. Sp. 2.

Artemisia. Wormucoorl. D.S. 3-4 ft. Sp. 1.

AlLIANCE 30. MYRTALES. (V. K. 51.)

Ord. 69. Alasgiace.s. Alangiads. (Lindl. 275; Loud. 61.)

Nyssa. Jupelo. D. T'. 10-15 ft. Sp. 4.

Ord. 70. Mretace.e. Miyrtleblooms. (Lindl. 282; Loud. 74.)

Punica. Pomegranute. D. S. W. Sp. 1; v. 5.

Myrtus. Mfyrtle. E. S. W. Sp. 1; v. 2. 
AllLANCE 31. GROSSALES. (V. K. 52.)

Ord. 71. Grossulariacee. Currantworts. (Lindl. 287 ; Loud. 32.)

Ribes. Currant. D. S. 2-10 ft. Sp. $45 ;$ r. 37.

Ord. 72. Escalloxiacee. Escalloniads. (Lindl. 288 ; Loud. 33.)

Escallonia. SE. S. 3-10 ft. Sp. 4; v. 3.

Itea. D. S. $2-5 \mathrm{ft}$. Sp. 1.

Ord. 73. Philadelphaces. Syringas. (Lindl. 289 ; Loud. 30.)

Philadelphus. Mock Orange. D. S. 3-10 ft. Sp. 12; v. 4 .

Decumaria. D. S. W. 4-5 ft. Sp. 1.

Deutzia. D. S. 3-10 ft. Sp. 2; r. 4.

AlLiance 32. "CINCHONALES. (V.K. 5.)

Ord. 74. Vacciniaces. Cranberries. (Lindl. 291 ; Loud. 43.)

Vaccinium. Bleaberry, Whortleberry. D. E. S. 1-10 ft. Sp. $32 ;$ v. 10.

Oxycoccos. Cranberry. SE. S. Tr. 1/2-2 ft. Sp. 3.

Ord. 75. CAPRIfoltaces. Caprifuils. (Lindl. 294; Loud. 40.)

Sub-ord. 1. LoNichere.

Symphoricarpus. Snowball-berry. D. S. 3-6 ft. Sp.4; v. 1

Dervilla. D. S. 3-4 ft. Sp. 1 .

Weigelia. D. S. 4-6 ft. Sp. 1.

Leycesteria. SE. S. W. $5 \div 7 \mathrm{ft}$. Sp. 1 .

Caprifolium. Honeysuckle. D. S. Sp. 18.

Sub-ord. 2. Sambucee.

Viburnum. Wayfaring-tree, Lauristine. D. E. S. 5-12 ft. Sp. 19 ; v. 11.

Sambucus. Elder. D. T. S. $4-30$ ft. Sp. 4 ; v. 8.

Alliance 33. UMBELlaLeS. (V. K. 55.)

Ord. 76. APIACEe. Umbellifers. (Lindl. 296.)

Bupleurum. SE. S. 4-6 ft. Sp. 2.

Ord. 77. Araliaces. Iryzorts. (Lindl. 297 ; Loud. 36.)

Aralia. Angelica-trce. D. S. 5-12 ft. Sp. 2.

Hedera. Ioy. E. Cl. Sp. 6 ; v. 8.

Ord. 78. ConNaces. Cornels. (Lindl. 298; Loud. 37.)

Benthamia. SE. S. sh. 5-12 ft. Sp. 1.

Cornus. Dogroood. D. S. 5-20 ft. Sp. 1; จ. 2.

Aucuba. E. S. 4-10 ft. Sp. 1.

Ord. 79. Hamamelidacee. Witch Hazels. (Lindl. 299 ; Loud. 37.)

Hamamelis. Witch Hazel. D. T. 15-25 ft. Sp. 1; v. 2.

Fothergilla. D. S. 3-6 ft. Sp. 1; v. 2.

Alliance 34. ASARALES. (V. K. 56.)

Ord. 80. SantalaceE. Sandalzoorts. (Lindl. 301 ; Loud. 61.)

Osyris. Puet's Cassia. SE. Tr. Sp. 1. 
Ord. 81. Lonastn.ı́.e. Loranths. (Lindl. 302; Loud. 39.)

Viscum. Misscltoe, E. Parasite.

Ord. 82. Antstolocinace.z. Bivthoorts. (Lindl. 303 ; Loud. 63) Aristolochia. Birlhoort. D. Cl. Sp. 2.

Conspectes of the Classes, Alliaxces, and Orders of the priecente Arrangeuent.

(The Number of Genera, Species, and Varieties are marked after cach Order.)

Crass ENDOGENS.

Alliance 1. Liliales.

Ord. 1. Liliacere.

Gen. 3 ; Sp. 17 ; r. 5.

Chass DICTYOGEXS.

Alliance 2. Dicryogexs.

Ord. 2. Sinilacer.

Gell. 1; s]) 16.

Class Gyirogens.

Alliance 3. G:':sogexs.

Ord.3. Pin:acer. 17; $119 ; 45$.

Ailietci.

C'upressece.

4. 'Тxacce. $5 ; 11 ; 5$.

Gen. 22 ; sp. 160 ; v. 50.

Crass EXogens.

Alliance 4. Amestalrs.

Ord. 5. Casuarinacere. $1 ; 1 ; 0$.

Ord. 6. Betulacere. $2 ; 23 ; 21$.

7. Altingiaces. $1 ; 2 ; 0$.

8. Salicacer. $2 ; 100 ; 30$.

9. Mrricacex. $2 ; 3 ; 1$.

10. Elanarnacere. $3 ; 11 ; 6$.

Gen. 11 ; sp. 140 ; v. 76.

Alliance 5. Unticalrs.

Ord. 11. Moracese. $3 ; 6 ; 13$.

12. Platanacex. $1 ; 4 ; 13$.

Gen. 4 ; sp. 10 - v. 26.
Alliance 6. Etphonbialus. Ord. 13. Euphorbiacex. $1 ; 2 ; 8$.

14. Enpetraceæ. $1 ; 2 ; 8$.

Gen. 2 ; sp. 4 ; v. 16.

Alliance 7. Qterialys.

Ord. 15. Corylacere. $6 ; 49 ; 70$.

16. Juglandacex. $3 ; 13 ; 26$.

Geı. 9 ; sp. 62 ; r. 76.

Alliance E. Garriales.

Ord. 17. Garryaces. $1 ; 2 ; 0$.

Geu. 1 ; sp. 2.

Alliance 9. Ninispermaleg.

Ord. 18. Menispermacere.

Gen. 2 ; sp. 3.

Alliance 10. Violales.

Ord. 19. Flacourtiacere. $1 ; 1 ; 0$.

20. Tamaricacex. $1 ; 2 ; 0$.

Gen. 2 ; sp. 3.

Alliance 11. Cistales.

Ord. 21. Cistacere. $2 ; 20 ; 20$.

22. Brassicacere. $1 ; 1 ; 0$.

Gen. 3 ; sp. 21 ; v. 20.

Alliance 12. Malvalfs.

O.d. 23. Malracex. $2 ; 2 ; 13$.

24. Tilincese. $2 ; 4 ; 11$.

Gen. 4 ; s]. 6 ; v. 24. 
Alliance 13. Sapindales. Ord. 25. Polygalaceæ. $1 ; 1 ; 0$.

26. Staphylcacex. $1 ; 2 ; 0$. 27. Sapindaces. $3 ; 15 ; 7$. 28. Aceraceæ. $2 ; 21 ; 19$. Gen. 7 ; sp. 39 ; v. 26.

Alliance 14. Gutriferales.

Ord. 29. T'ernstrœmiaceæ. $3 ; 4 ; 0$. 30. Hypericacer. $1 ; 9 ; 2$. Gen. 4 ; sp. 13 ; v. 2.

Alliance 15. RaNales.

Ord. 31. Magnoliacex. 2; 11; 11 .

32. Anonaceæ. $1 ; 1 ; 0$.

33. Ranunculaceæ. 4; 21; 24. Gen. 7 ; sp. 33 ; v. 35.

Alliance 16. Berrerales.

Ord. 34. Berberidaceæ. $2 ; 26 ; 11$.

35. Vitacer. $2 ; 6 ; 3$.

36. Pittosporaceæ. $3 ; 3 ; 0$.

Gen. 7; sp. 35 ; v. 14.

Alliance 17. Ericale8.

Ord. 37. Ericaceæ.

Ericeæ. $11 ; 69 ; 46$.

Rhododendreæ. 6;61; 120.

Gen. 17 ; sp. 130 ; v. 166.

Alliance 18. Rutales.

Ord. 38. Anacardiacere. $3 ; 14 ; 15$.

39. Xanthoxylaceæ. $3 ; 4 ; 2$.

40. Oclnacere. $1 ; 1 ; 0$.

Gen. 7 ; sp. 19 ; v. 17.

Alliance 19. Silenales.

Ord. 41. Polygonacex.

Gen. 3 ; sp. 6.

Alliance 20. Chenopodales.

Ord. 42. Chenopodiacer.

Gen. 3 ; sp. 5.

Alliance 21. Daphnales.

Ord. 43. Thymelacee. $3 ; 16 ; 6$.
Ord. 44. Jauraceæ. $1 ; 1 ; 6$. Gen. 4 ; sp. 17 ; v. 12.

Alliance 22. Rosales.

Ord. 45. Calycanthacer. 2; 12; 12.

46. Fabaceæ. $25 ; 130 ; 69$.

47. Dupracex. 5; 52 ; 52.

48. Pomaceæ. $8 ; 97 ; 98$.

49. Rosacer. $7 ; 108 ; 54$.

Gen. 47 ; sp. 399 ; r. 285.

Alliance 23. Saxifragaleb.

Ord. 50. Hydrangeaceæ.

Gen. 1; sp. 6 ; v. 1.

Alliance 24. Rhamnaleg.

Ord. 51. Ulmacee. $3 ; 33 ; 44$.

52. Rhamnacex. $6 ; 27 ; 6$.

53. Celestraceæ. $4 ; 10 ; 0$.

54. Sapotaceæ. $2 ; 6 ; 0$.

55. Styraceæ. $2 ; 7 ; 0$.

Gen. 17 ; sp. 83 ; r. 50.

Alliance 25. Grevtiayales.

Ord. 56. Ebenacpe. $1 ; 4 ; 2$.

57. Aquifoliacese. $4 ; 20 ; 30$.

58. Apocynaceæ. $1 ; 1 ; 6$.

Gen. 6 ; sp. 25 ; v. 38.

Alliance 26. Soraxales.

Ord. 59. Oleacer.

Oleæ. $4 ; 14 ; 9$.

Fraxinex. $5 ; 30 ; 32$.

60. Solanaceæ. $5 ; 10 ; 0$.

61. Asclepiadaceæ. $1 ; 1 ; 0$.

Gen. 15 ; sp. 55 ; v. 41.

Alliance 27. Euhales.

Ord. 62. Jasminacex. $1 ; 7 ; 3$.

63. Lamiacee. $3 ; 3 ; 0$.

64. Verbenaceæ. $1 ; 3 ; 1$.

65. Myoporacee. $1 ; 1 ; 0$.

Gen. 6 ; sp. $14 ;$ v. 4 . 
Alliance 28. Bigroxlales. Ord. 66. Bignoniace飞. $3 ; 4 ; 0$.

67. Sclirophulariaceæ. $3 ; 3 ; 0$.

Gen. 3 ; sp. 7.

Alliance 29. Campaxales. Ord. 68. Asteracex. $2 ; 3 ; 0$. Compositce.

Gen. 2 ; sp. 3.

Alliance 30. Mrrtales.

Ord. 69. Alangencere. $1 ; 4 ; 0$.

70. Myrtacex. $2 ; 2 ; 7$.

Gen. 3 ; sp. 6 ; r. 7.

Alliance 31. Grossales.

Oru. 71. Grossulariaceæ. 1; 45; 37.

72. Escalloniacex. $2 ; 5 ; 8$. 73. Philadelphacer. $3 ; 15 ; 16$. Gen. 6 ; sp. 65 ; r. 41.
Alliance 32. Ciscrovales.

Ord. 7.4. Vacciniacer. $2 ; 25 ; 10$.

75. Caprifoliacex. $8 ; 60 ; 27$

Lonicerca.

Sambucec.

Gen. 10 ; sp. 95 ; v. 37.

Alliance 33. Usablzales.

Ord. 76. Apiacere. $1 ; 2 ; 0$.

77. Araliacex. $2 ; 8 ; 8$.

78. Cornaceæ. $3 ; 3 ; 2$.

79. Hamaunelidacea. $2 ; 2 ; 4$.

Gelı. 8 ; sp. 15 ; v. 14.

Alliance 34. Asarazfs.

Ord. 80. Santajacex. $1 ; 1 ; 0$.

81. Loranthacere. $1 ; 1 ; 0$.

82. Aristolocliacese. $1 ; 2 ; 0$.

Gen. 3 ; sp. 4.

Note.-The extent to which the varieties of plants and trees in the arboretum may be carried is to be measurably governed by the locality. Liberal as the foregoing list may appear, it can be largely and profitably extended by selections from our American forests, while some of the trees and plants named should be excluded, from their unsuitableness to the climate.-ED.

A careful inspection of the preceding synopsis will suggest most of the scientific principles on which the arrangement of an arboretum must proceed. It will be understood that the indiridual species of plants unite to form genera, the lowest but inost perfect combinations of vegetables that exist in nature. It will also be perceived that cognate genera coalesce into orders, which are the next important argregrations; and these orders, by a highly refined analysis and $1.4 \%$ 
synthesis of character's, are made to comprise alliances and classes. These successire combinations, then, give rise to what we may eall generic, cardinal, allied, and classific groupings; the last, however, we mention chiefly for the sake of completeness, because, though carefully preserred, it will be almost invisible, except in one or two cases, on account of the multitude of subordinate members which it inclndes. Every one will admit the propriety of planting each genus by itself, and this accordingly is the first step in the arrangement. But the genera, as spread out on the ground, may be combined into orders; and these orders, again, may be made to ocenpy such positions that the allied races, or "alliances," may be marshaled together in space, and may be exhibited to the eye in living presence as well as presented to the understanding in theory. It is to the proper collocation of the orders and alliances that attention must be chiefly directed in the scientific treatment of the arboretum.

- A consideration of the synopsis will bring out other important results. By tracing the numbering of the orders and alliances, as quoted from "The Tegetable Kingdom" of Dr. Lindley, the reader will observe that many of the orders, alliances, and eren classes, which exist in a complete system of plants, are excluded from our list by the conditions imposed by onr cold climate and the arborescent growth of the subjects employed. The orders that remain are often found in a sadly mutilated state. In the Fabacece, for example - the old "pea tribe," or the Papilionaceous order, as it was wont to be called - the genera, as estimated in "The Vegetable Kingdom," amount to 467 , while we have been able to assign only twenty-five as 
available to our present purpose. It is hardly needful to point out the immense elisruption of affinities these chisms must cause, both in the allimees and the internal structure of the orders. Hence the arrangements of an arboretum can be at best only fragmentary; but that is no reason for neglecting or disregarding the materials for combination which are within our reach. The fragments that remin to us are capable of assuming a highly scientific form, and so may be invested with attractive interest.

Now, in planting the trees and shrubs of an arboretum we miglat begin at one ent of the classification, it matters not at which, and taking the first genus that came to hand, we might put down its species in a straight or curved line, or double line, and we might proceed to the other gencra suecessively, till we had gone through the whole series, as we would wind off a thread from a reel. The lines might be drawn along a border within the four sides of an inclosure, or might occupy narrow parallel borders, separated by walks, or might assume the form of a spiral, running fiom the exterior of the space to its center, or reversely. This is what we have already called the lineur arrangement; but though it has been adopted in some nurseries for the sake of mercantile convenience, it is highly objectionable in various points of view. Not to speak at present of the sacrifice of beauty thus made, it is evident that this collocation preserves only the affinities which a genus or order bears to that immediately preceding, and to the other immediately succeeding; and these undoubtedly do not include the whole of its relations. As already noticed, Dr. Lindley, in his "Vegetable Kingdom," appends to each of his orders 
an instructive exhibition of its position; that is, he puts the order in question in the center, and right and left of it the two orders in main affinity, while two in weaker aflinity are placed over and under it at right angles. We have tlius a star, composed of a nucleus and four rays, and it is probable that it would be easy, in some cases, to multiply the rays considerably. Something of this kind ought to be adopted on the ground; but it is not difficult to perceive that the stellar arrangement, if attempted to be strictly carricd out in practice, wonld lead to great complication of figrue, and, fiom the interlacing of affinities, might produce inextricable confusion. The orders, then, must be formed into rininor groups or masses of varying form and size, according to their extent-some genera will regiuire a considerable group for themselves - and these subordinate members must be combined and coördinated in conformity with the principles of the alliance of which they furn parts. Only the main relations can be taken into acconnt; and the combination shonld approach that of a map, according to the old illustration, suggested, we believe, by Linnæus himself. Let the reader take a colored map of England, and select one of the midland counties - such as Leicestershirehe will find six other connties conterminous with it, and bounding it by frontier lines of varying form and length. Nothing can afiord a better image of an order or alliance of orders, in the natural system, as represented on the ground. Of course, when planted, the boundaries of the respective genera or order's must not be in actual contact. They should be separated, not by a dotted line as in maps, not by a narrow grass verge as in some gardens, but by lawns of a sufficient 
breadth to allow the distinctive characters of the groups to be perceptible. The distance or proximity of the groups - in other words, the breadths of the lawns - are to be regulated according to the closer or more remote character's of the prevailing aftinities.

It is only in the botanic garden, in the public park, or in private grounds where botanical characters are in high consideration, that an arboretum, in its full extent, can be arranged on strictly scientific principles. Even in these the system can be carried out with rigid precision only at the expense of some baldness, and with no small allowance of the dotting nuisance. For the sake of public instruction, or for other purposes, a very complete collection may be desirable - the larger the better, we would say; but as no eye can possibly command 2500 trees and shrubs at once, we should be disposed to recommend the free use of those tall and conspienous genera and species which are naturally fitted to harnonize the more discordant elements of the scenery. It must be remembered that in every collection of trees there are a variety of considerations which must be taken into account, particularly in connection with private residences. There is the interest arising from the rarity of the species and the completeness of the assemblage - qualities that will have preponderating weiglt where botanical partialities are strong. There is the satisfiction derived from contemplating the beauty and mannitude of particular specimens of trees; and that will be chiefly afiected by the lovers of arboriculture in itself. And the stulent of the picturesque will be attracted by the peculiar plyysiognomy of uncommon plants and by the secnic effect of the whole. Some of these features of an arborctum, 
as separable from its strictly scientific character, we shall endeavor to review in the following section.

Note-The planter of an arboretum must bear in mind that none but plants suited to the soil, as well as climate, will give him satisfaction in their growth and development. The qualities of moisture, and dryness, to which they are partial, should also be studied; for while many varieties will bear a wide range of either, others can only be successfully propagated in such soils as correspond to their native localities.-ED.

Secr. II.-Decorative Trentment of an Arboretum.

In this part of our subject, we return to the principal object of our little work, viz: the adornment of country residences. It is to be presumed, that there are few who are willing to contemplate a living collection of trees and shrubs without experiencing the pleasurable emotions which their elegance of form and beauty of tint are fitted to inspire. In such as would dispense with these enjoyments, the scientific instinct inust be very strong indeed. We trust that the vast majority of our readers would rejoice to find a new source of pleasure in an olnamental assemblage of plants. We come, then, to consider low, in the construction of an arboretum, the botanic interest may be modified, and its scientific rigor softened, while its exactness may not be seriously impaired.

In the arrangement of the arboretnm, there are certain orders and alliances which include tho trees of largest growth; these claim special attention for the selection of their position, as they not only require a 
liberal allowance of space, but also become the principal objects on accomt of their breadth and altitude. They are mostly to be found in Allianees $3,4,7,12$, $13,22,24,26$. In distributing them on the ground, their groups, of whaterer rank they may be-i.e. whether generic, ordinal, or allied-slould be so managed as not only to be in requisite union with the cognate families of humbler growth, but also to become the leading and most conspicnous features of the scene. Where this expedient is properly employed, it will add much variety to the whole, and will produce a greatly superior effect to that attained by a mere botanical suceession, or by the intermingling of many genera in the same group, or where the place assigned to each plant is determined by its stature, and not by"its generic character. Though we disapprove of the intermingling of genera with eneh other, we hold that many of them may be put in juxtaposition. There are even certain alliances in which the numbers of genera and species are so limited that they may very properly form combined groups, as in the following associated pairs: 8-9, 10-11, 19-20, 27-28, 29-30.

Between the different groups of trees and shrubs, lawns of varying brcadth should be interposed; the broader lawns being partly occupied with clumps of low-growing trees and slurubs, and the narrower glades being left entirely open. The distance at which the trees and shrubs shonld be planted in their respective groups must depend on the magnitude which the individual species acquire in this country. While there should be space for a pretty full development of each, they should, generally speaking, not be placed at such distanees apart as to prevent varions members of the 
group from coming into contact with each other, when they have attained a considerable size. At the same time, the finer and more graceful forms should be so stationed as to appear to the greatest advantage; and to those that are less important may be assigned inferior places. The margins of the large groups may be feathered by smaller ones, or by single trees and shrubs; but this must be done so irregularly, and with such a leaning forward in the major mass, or with snch other relation between it and the single trees, as to obviate the effect of dotting, which, as the besetting sin of arboretums, ought to be carefully guarded against.

On ground with a flat surface, and soil of a uniform quality, a combined botanical and pictorial grouping of the whole collection will be the principal object of study. Certain shrubs will require special soils, such as peat and sand, and these should be formed for them. Where there is a considerable diversity of surfaces and soils, attention ought to be directed not only to the grouping on the principles already indicated, but also to the effect of the proposed distribution in relation to the surface which is to be covered, and to the soils on which the plants are to grow. We must consider what group will appear to most advantage on a given hill, or knoll, or slope, or hollow, and whether also the soils of these may not be more suitable for one order or family than for another. A fine hollow with moist soil might seem, at first sight, to promise a propitious site for willows, alders, and poplars; and Jet, on examination, it may be found that such.locality may be better adapted, both in reference to beauty and luxuriance of growth, for the hardier sorts of what 
are usually called American shrubs. On the other hand, it may be ascertained, with some degree of certainty, that the low, damp space referred to wonld prove injurious to the more tender pines, cistus, magnolias, and arbutus. The diversities of climate arising from differences in exposure and evaporation, even within the limited space of a dozen acres, is often very considerable. We are aware, that to attend properly to these and similar considerations is no easy matter; but they do not on that account lose their importance, and they should, if possible, receive the attention which is due to them.

In an arboretum arranged on strictly botanical principles, there is an invariable deficiency of the effect produced by evergreen trees, as these valuable merns of decoration are mostly confined to Orders 3 and 4, viz: Coniferce and Taxacese, and in the method proposed they are all placed in one locality. To counteract or contrast with the bare and impoverished aspect, during winter, of the decidnous tribes which pervade the arborctum, we would recommend the severance of these evergreen orders into generic, or even subgencric groups, which, if properly distributed and convected, would tend to relieve the effect adverted. to, without their losing, to any considerable extent, their rightful position in their own orders. But even if their ordinary continuity were to suffer interruption, it were better that it should be so, than that they should all be confined to one place. We also recommend the employment of the ordinary erergreen shrubs as promiscuous underwood, in many of the tall deciduous groups; this will not inaterially affeet their scientific character, while it imparts to the whole grouping 
a more clothed character, and improves the general effect of the ornamental scenery.

Hitherto we have been adverting to an arboretum formally constructed as such, and of considerable extent; we may now view it as an appendage to the park and pleasure-grounds of a country residence. In such a case, its site should be chiefly in the pleasure-gromuds, where it can be mingled with, or made to form a part of the dressed grounds. Such a position is generally advantageons, as the walks and keeping of the environs afford great facilities for the culture and the display of trees and shrubs. TVe would, however, by no means recommend the oceupation of the whole grounds with a botanical arboretum. A place of this description would present numerous groups of a scientific cliaracter; but the incessant variation of the forms and foliage of the trees and shrubs wonld certainly diminish greatly, if it did not altogether destroy, the harmonious repose produced by considerable misses of the same kind of tree. Groups composed of single specimens of the different species of oaks, (Quercus.) elms, (Ulmus,) planes, (Acer,) etc., would be utterly defieient in that graceful and impressive dignity which is exhibited by large groups and masses of the English oak and other common species of the above mentinied genera. We do not deny that there are other species of these genera but little known, which would be as effective were they treated in the same way; but we mean that in ornamental planting there must be sume breadth of the same bonghs and foliage before any pleasure can lie conveyed to the mind apart from the interest created by variety.

In making part of the pleasure-grounds the basis of 
the arboretum, we would form the large groups or masses of a magnitude proportioned to the extent of the place, and we would plant them with the finest trees, whether old or new, to constitute the leading features of the scene. Taking these as the groundwork, we would relieve or set them off by single trees of the species belonging to the same genera, throwing groups of a similar composition into the adjacent places of the park; or, using the same groundwork as before, we would introduce generic, ordinal, or allied groups of selected species into such positions as would eontribute to the variety and beauty of the whole. We strongly recommend the selection of materials to proprietors forming arboretums in the vicinity of private residences. There are some hundreds of trees and shrubs which may safely be left to the botanic garden and public park. Probably there are few genera which deserve to be taken in the whole. On the other hand, there are many fine trees and slirubs but little planted, which, with judicious treatment, might tend to remove the reproach of "the shrubbery's insipid scenes." Much remains to be done in this way; and it is not to be doubted, that a moderate-sized but well-selected arboretum is the most effectual means of doing it. It may be added, that, though the pleasure-gromnd affords the most desirable site for the arboretum, there are many parks in which it may be planted in the woods, especially where there are walks, or where they can easily be formed. On the outskirts of the woods, or along the sides of open rides penetrating into their interior, a pretty full arboretum might be formed, composed of trees and of the stronger and less ornamental shrubs, reserving the more showy or less bardy 
species of both for the decoration of the dressed grounds An arboretum in the woods might exlibit more of the linear arrangement than is admissible in any other situation; and the irritative variety, which is felt to be so offensive in the pleasure-ground, would be softened, if not wholly sunk in the ponderous masses of the surrounding trees.

Note.-To such as possess the opportunity, with sufficient means, taste, and leisure to get up an arboretum in the proper way, it will be a most delightful occupation. We know of no complete thing of the kind yet attempted in the United States. An arboretum should be adopted at some appropriate spot attached to an institution of learning or science in every one of our states; and as we progress in science, art, and refinement, arboretams will probably be attempted by state or corporate authority. A single life is too short to prodnce mature effect in a work of such magnitude. and they should hardly be attempted, except under the perpetuated existence of an institution, either state or corporate, where the finl effect sought by such a work may be accomplished.-ED. 


\section{CHAPTER XIV.}

THE PINETUM.

Remarks on Special Collections of Trees - The Pinetum $\rightarrow$ Materials and Arrangement - Enumeration of Species, with Obserrations on the Groups - Effects of Climate - Soil - Early Cultiration of the Plants - Planting of the Pinetum - Pruning of the Trees - Decorative Treatment of the Pinetum.

MLAxy persons, whose limited domains do not permit, or whose scientific zeal does not incite them to plant an arboretum, may yet be induced to form extensive collections of a few particular genera. A botanist, for example, may begin by cultivating a few willows, in order to study their characters at his leisure, and he may add to his stock till it swells out to a magnitude approaching that magnificent Salicetum existing at Woburn Abbey. So a lover of wild roses may extend his attention and predilection to the whole of the species and numerous varieties of that beautiful family; and such has been the origin of many fine rosaries. We should like to see this method of special culture more fiequently exemplified. We have observed a long walk in a pleasure-ground, skirted by a row of oaks, exhibiting many diversified seminal varieties, if not distinct species, and the thought occurred that it would be a fine thing to have a broad ride bordered with oaks in the sunny expanse of a wide park, 
or in the open glades of a sheitered forest. We are assured that a quercetım, an aceretum, and varions other analogous collections, might be formed, possessing great value in themselves, and imparting a decided character to a place which, from its linnited extent, or other circumstances, might be naturaliy uninteresting.

The pinetum is unquestionably the most important of all the special collections of trees, whether as a membel of a general arboretum or as planted by itself; and accordingly it is deservedly receiving increasing attention thronghout the country. From the low banks of the Thames to the subalpine slopes of the Grampians, it is year after year more frequently planted. This very interesting collection of trees is composed of the natural families of pine, cypress, yew, and other kindred races, or what, in popular, though not very accurate language, are called Conifers. At present, there are in cultivation about twenty hardy genera, and nearly two hundred and eighty distinct species and varieties, which, with the exception of about fifteen, are evergreen. From a fourtl to a third of the whole may be considered sub-hardy in many localities. A number of them are shrubs; but the most are tall trees, even in this country, and in their native habitats some attain a prodigious altitude. Deducting the low and bushy sorts, there still remain a sufficient number, when one of a species or variety in the extensive genera, and one or two in the smaller are employed, especially if well arranged in generic and subdivisional order, to furnish an evergreen arboretum of several acres, room being allowed for the full development of the trees.

In order to render our observations intelligible, as 
well as to have an opportunity of conveying useful information, we deem it needful to give an enuneration of the species which hare been ascertained, or may be expected to live and thrive in our climate. We adopt the scientific arrangement and nomenclature of Endlicher, as best suited to our present purpose.* To the sereral groups and subdivisions we shall append brief remarks on their respective characters, or on other matters connected with them worthy of notice. At the end of the chapter, we shall offer some general observations on the influence of soil and climate in relation to these trees, and on the pictorial arrangement of the Pinetum as a whole. The reader is requested to remember that when no indication is given the species is known to be hardy; that $h$ ? denotes that this character is doubtfinl; $s h$ means sub-hardy; and that the figures attached to the right of the specific names mark the average or probable height in feet. An asterisk is prefixed to a few species not yet introduced into this comntry.

\footnotetext{
"It will be observed that the arrangement of Endlicher, taken from his "Synopsis Coniferarum," and corresponding to the class and alliance Gymnogens of Lindley, differs in the order of sequence from that given from "The Vegetable Kingdom," in our Synopsis of Orders in the chapter on The Arbnretum. We do not profess to adjudicate on their respective scientific merits. Perhaps the latter is better adapted to express the external relations of the Order in a general system. In a detached Pinetum, we should prefer Endlicher's subdirisions. The reader may adopt either, as it suits his conrenience.

Much valuable and interesting information, regarding pines and the kindred genera, may be found in Messrs. Lawson and Son"s "List of Plants of the Fir Tribe," and in Messrs. Knight and Perry's "Synopsis of the Conferous Plants grown in Great Britain."
} 


\section{SYNOPSIS}

\section{OF THE ARRANGEMENT OF THE PINETUM.}
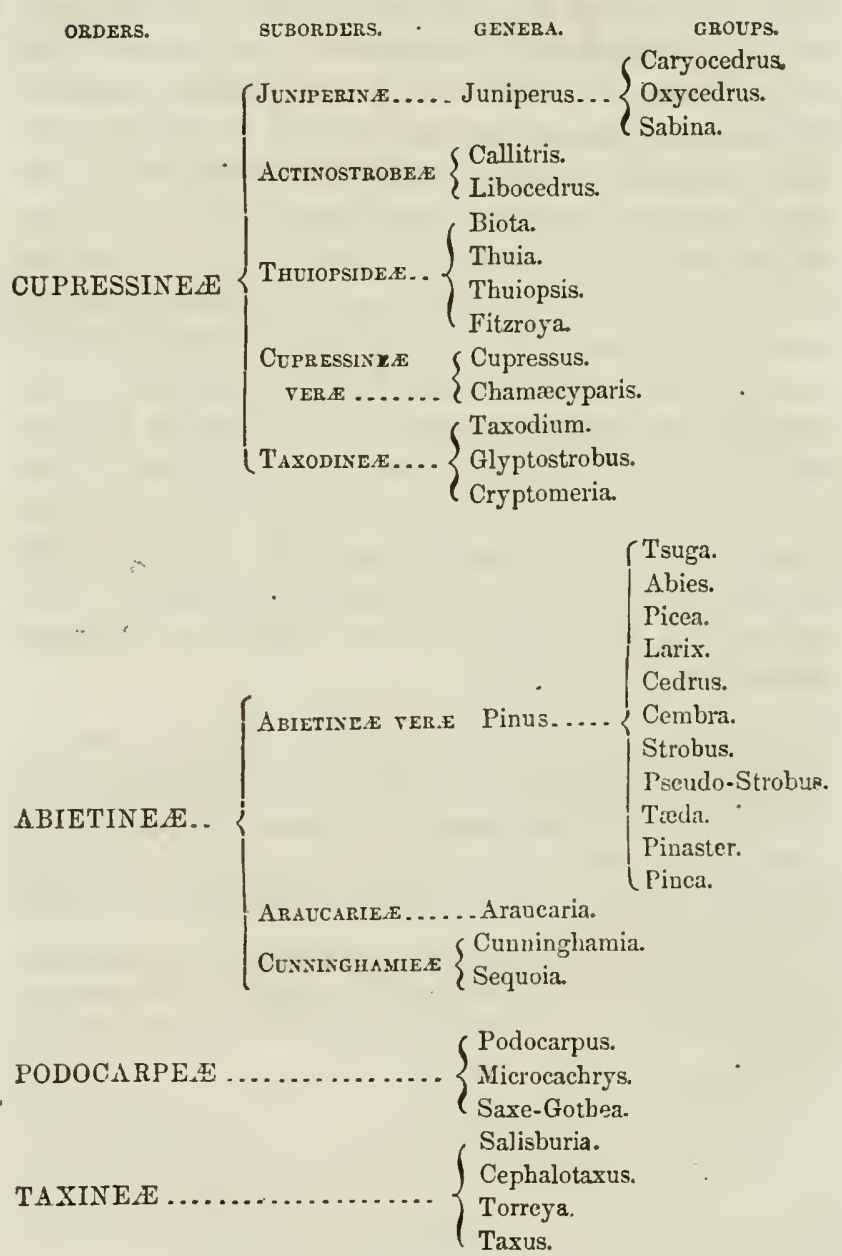


\section{ORDER I. CUPRESSINEAL.}

\section{Suborder I. JUNIPERINE.}

Gen. 1. JUNIPERUS.

\section{Jusweres. - Group 1. Caryocedrus. \\ 1. J. dupracea, bush.}

\section{Juxiperes. - Group 2. Oxycedrus.}

2. J. macrocarpa, 10-12 ft.

3. J. Oxycedrus, 10-12 ft.

4. J. rufescens, bush.

5. J. brevifolia.

6. J. hemispharica, 1-3 ft.

7. J. nana, 3-5 ft.

8. J. $\longrightarrow$ alpina.
9. J. communis, 4-20 $\mathrm{ft}$.

10. J. rulgaris, bush.

11. J. - Hispanica, 10-15 ft.

12. J. _- Caucasica, bush.

13. J. - arborescens, $10-18 \mathrm{ft}$.

* I4. J. rigida.

*15. J. taxifolia.

In this group, none of the sorts reach the habit of trees. The foliage of $2,7,13$, is of a light green, with a glaucous hue; 10 and 11 are of a deep green. Those of an crect form, $2,3,11,12,13$, group well with spreading shrubs, 12 has fine drooping branchlets; the others are suitable for rockworks or for covering bare sandy knolls.

16. J. prostrata.

$$
\text { Junireris. - Group 3. Sabina. }
$$

17. J. recurva, shrub.

18. J. squamata, 3-6 ft.

19. J. Darurica, tree.

20. J. Chinensis, 20-30 ft.

21. J. Pseudo-Sabina, bush.

22. J. Sabina, 3-4 ft.

23. J. - humilis.

24. J. - variegata.

25. J. sabinoides, bush.

26. J. nophora, s $h$, bush.

27. J. fotidissima, tree.

28. J. excelsa, tree.

29. J. - nana.

30. J. procera, trec.

\section{Position Doubtful.}

45. J. Gossinthanca, h?

47. J. gracilis.

\section{Doubtful Species.}

46. J. Japonica.

48. J. cernus.
31. J. occidentalis, $h$ : $15-30 \mathrm{ft}$.

32. J. Virginiana, 20-30 ft.

33. J. _- australis.

34. J. _- variegata.

35. J. - - glauca, $h^{2}$

36. J. _- argentea.

37. J. _- pendula.

38. J. Mexicana, h? trce.

39. J. fiaccidą, h: tree.

40. J. Bermudiana, he tree.

41. J. tetragona, h? shrub.

42. J. Phœnicen, sclerocarpa

43. J. - malacocarpa.

44. J. sphrerica, tree. 
49. J. dimorpha.

50. J. aquatica.

51. J. glauca.

52. J. Cedro.
53. J. racemosa.

54. J. prostrata.

55. J. religiosa.

The size and forms of the species of this group are rery raried; 27 , 28 , and 31 are prramidal ; 20 and 26 are oblongated, as is also 32 when young; 17 and 37 are fine shrubs with erect branches anu pendulous branchlets; 26 and 44 are erect, with loose spreading uranches: 42 is pyramidal, with slender weeping branches; $16,23.21$ are prostrate shrubs. The foliage of $21,36,39$ is of a light silvery green ; 28, 34, of a glancous green ; 22 and 32 , of a somber green, and the latter with a glaucous tint; $18,25,27,32,41$, are of a dark green color. J. procera (30) is a large useful timber tree in Abyssinia.

\section{Suborder II. ACTINOSTROBE.E.}

Gen. 1. CALLITRIS.

1. C. Quadrivalris, he tree.

Gen. 2. LIBOCEDRUS.
1. L. Doniana, $l$ : $30-70 \mathrm{ft}$.
3. L. Chilensis.
2. L. tetragona.

Callitris is a large tree from Nount Atlas, with horizontal branches, and shining green leaves. Libocedrus 2 and 3 are from the Andes of Southern Chili and Patagonia, where, it is said, they rival Araucaria imbricata, and are both very fine trees; 3 has a pyramidal head resembling the upright cypress, with drooping branchlets and ririd green foliage.

\section{Suborder III. THUIOPSIDE.E.}

Gen. 1. BIOTA.
1. B. orientalis, $10-15 \mathrm{ft}$.
6. B. orientalis pyramidalis.
2. B. - expansa.
7. B. Tartarica, tree.
3. B. - glauca.
8. B. stricta, tree.
4. B. - Nepalensis.
9. B. pendula, bush.
5. B. - Sieboldii.

The species of Biota, or Chinese Arbor-rita, furm handsome erect shrubs, of a compact labit and of rather slow growth. B.pendula (9) is an elegant bush or small tree, with slender branches and thread-like dronping branchlets. The foliage of 1 is bright green when Joung, acquiring at length a dark somber color; 3 has a light glaucous hue, and 9 a light green. 


\section{Gen. 2. THUIA.}
1. T. occidentalis, $20-30 \mathrm{ft}$.
3. T. gigantea, $h$ ? $\mathrm{C0}-\tilde{r} 0 \mathrm{ft}$.
2. T. plicata, tree.

These species, popularly called Arbor-vite, are of more rapid growth than those of the previvis genus; 1 is of an elongated pyramidal form when young, becoming afterward more spreading and irregular, and is of a light tawny green; 3 is a handsome tree, with spreading branches.

Gen. 3. THUIOPSIS.
1. T. dolobrata, h?
2. T. flagelliformis, $h$ ?

These are handsome trees, resernbling the Arbor-riter, but of duubtful hardiness.

\section{Gen. 4. FITZROYA.}

1. F. Patagonica, $100 \mathrm{ft}$.

\pm beautiful evergreen tree recently introduced trom Patagonia, -with drooping branches and shining green leaves; it resembles Libocedrus tẹtragona when old.

\section{SUgorder IV. CUPRESSINEJE VER.Z.}

Gen. 1. CUPRESSUS.
1. C. horizontalis, $30-40 \mathrm{ft}$.
7. C. thurifera, tree.
2. C. sempervirens, $30-40 \mathrm{ft}$.
8. C. funebris, $60 \mathrm{ft}$.
3. C. torulosa, $60-100 \mathrm{ft}$.
9. C. Uhdeana, tree.
4. C. - elegans.
10. C. Goreniana, $10 \mathrm{ft}$.
5. C. - viridis.
11. C. macrocarpa, $60 \mathrm{ft}$.
6. C. - glauca $l i 210-30 \mathrm{ft}$.
12. C. Lindleyi, tree.

This is a beautiful genus, of which most of the species have an erect habit, with horizontal branches; 2 has upright branches, and is the well-known ornament of cemeteries on the shores of the Mediterranean; 6 is the cedar of Goa, a spreading tree with pendulons branches; 8 has bcen already described, p. 148; 11 has tabulated branches, like the Cedar of Lebanon. The foliage of 1 and 2 is of a somber, $3,6,8$ of a glaucons, and 10 and 11 of a virid green. C. macrocarpa is a good timber tree, and thrives well in poor soils and exposed positious in England.

\section{Gen. 2. CHAMECYPARIS,}
1. C. sphæroidea, tree.
6. C. ericoides, h? bush.
2. C. - atrovirens.
7. C. Nutkaensis, tree.
3. C. - glauca.
8. C. thurifern, tree.
4. C. - follis rariegatis.
"9. C. obtusa, 60-80 ft.
5. C. Bquarrosa, hq bush.
*10. C. pisifera, tree. 
Some plants of 1 , the white cedar, have a compact, and others a spreading habit; 3 has gracefully eurred branches, with numerous spreading branchlets. C. thurifera is a spreading tree. The foliage of 2 is of a deep green; and that of 3 and 5 of a glaucous green.

\section{Suborder V. TAXODINEJE.}

Gen. 1. TAXODIUM.
1. T. distichum, 50-100 ft.
3. T. micropliyllum, $h$ ?
2. T. adscendens, $h$ ? tree.
4. T. Hugelii, $h^{2}$ tree.

This is a deeiduous family, with beautiful light green foliage. T. distichum, the well known deciduous Cypress, is of a slender pyramidal form, growing to a large size in England, as at Sion House; but which, though barly iu most places in Scotland, scarcely ever grows above 12 or $\mathbf{1 5}$ feet high. The other species are not more robust.

\section{Gen. 2. GLYPTOSTROBUS.}
1. G. heterophyllus, small tree.
2. G. pendula, h.2 bush.

This is a new genus established by Endlicher. The species are shrubs or low trees, not yet much known.

\section{Gen. 3. CRYPTOMERIA.}
1. C. Japonica, $h$ : 60-100 ft.
2. C. nana, he bush.

The first species becomes a large tree in China; but it is still doubtful whether it will be more than a bush in this country. It succeeds best in a mild, moist climate.

\section{Order II. ABIETINEE.}

\section{Suborder I. ABIETINEJE VERJE.}

Gen. 1. PINUS.

$$
\text { Pixus. - Group 1. Tsuga. }
$$

(Cones drooping. Leares solitary and flat.)
*1. P. Tsuga, 25-30 ft.
4. P. Douglasii, $150-200 \mathrm{ft}$ :
2. P. Brunoniana, $h$ ? $70-80 \mathrm{ft}$.
5. P. — taxifolia
3. P. Canadensis, $20-50 \mathrm{ft}$.

Species 1 has not yet been introduced; 2 and 3 are broad bushy trees, the latter, from its slow growth, is well adapted for the shrubbery ; 4 is of a pyramidal form, of prodigious size, and of unusually rapid growth. The foliage of 2 is glaucous, of 3 a dark, and of 4 a vivid green. 
Pinve. - Group 2. Abies, Lndl.; Picea, Loud.;-Silver Firs.

(Cones axillary and upright. Leares sulitary, flat, silvery beneath.)

B. P. bracteata, $120 \mathrm{ft}$.

7. P. nobilis, large tree.

8. P. Fraseri, $10-20 \mathrm{ft}$.

9. P. - nani.

10. P. religiosa, $s h$.

11. P. Nordmanniana, $80 \mathrm{ft}$.

12. P. Abies $d u R o i, 50-100 \mathrm{ft}$. Picea, Linn. Silver Fir.

13. P. - pendula.

14. P. — tortuosa.

15. P. - pyramidalis.

16. P. - foliis variegatis.

*17. P. —— Ieioclada.

18. P. Cephalonica, $60 \mathrm{ft}$.
*19. P. firma, trce.

"20. P. homolepis, 20-30 ft.

*21. P. bifida.

"22. P. concolol.

23. P. balsamea, 40-50 ft.

24. P. amabilis, $150-200 \mathrm{ft}$.

25. P. grandis, $170-200 \mathrm{ft}$.

26. P. lasiocurpa.

27. P. Pindrow, $80-100 \mathrm{ft}$.

28. P. Webbiana, $h^{2} 80-100 \mathrm{ft}$.

29. P. Pichta, 60-70 ft.

30. P. Pinsapo, $60-70 \mathrm{ft}$.

"31. P. Mertensiana.

This is perhaps the most remarkable section in the family of Pines, in respect to botl the size and beauty of the trees. Their forms are generally pyramidal, or of the spiry cone. $P$. Abies, or Silver Fir, is a truncated pyramid, and we believe that many of the others will approach that form when they have grown long enough anong us to attain to their maturity. P. Piudrono and Webbiana, from the Himalayas, assume a columnar shape. $P$. Cephalonica, if not a broad-headed tree, has such long horizontal branches as to produce a rery broad cone: tho same remark spplies to $\boldsymbol{P}$. Pinsapo. The form and disposition of the branches impart the characteristic features of this group. In 7 and 29 they are flat and tabulated; : 18 and 30 they are rigid, horizontal, and verticillate, giving a very symmetrical habit to the trees; in 27 and 29 they are close, spreading in whoris, witl dirooping branchlets. The foliage in 7,18 , and 30 is closely set : in $7,8,12,13,14,15,23$, and 27 it is of a dark green ; in 29 of a vivid green; in 18 and 30 of a lighter rivid green; in 11 of a light pale green; and in 25 of a silvery green. The branchlets of some sorts such as nobilis, Ceplalonica, and Webbiana, are lizble to be injured by spring frosts when the trees are young; but if planted in shady places or in late situations they seldom receire injury. The timber of the silver firs is generally of inferior quality. $P$. Cephalonica produces hard and durable timber. Though many of this group will thrire tolerably on poor ground, they attain inuch greater perfection in soils of good quality. $P$. Webbiana thrives in poor clay soils. 
Prscs. - Group 3. Picea, Endl.; Abies, Lond.; - Spruces.

(Cones drooping, terminal. Leaves solitary and tetragonal.)

32. P. Menziesii, $t$ 'ce.

33. P. alba, $50 \mathrm{ft}$.

34. P. - nana.

35. P. rubra, $30 \mathrm{ft}$.

36. P. — violacea.

37. P. - arctica.

38. P. longifolia.

39. P. nigra, $80 \mathrm{ft}$.

40. P. - rariegata.

4i. P. orientalis, tall tree.

42. P. Picea du Roi. Abies, Linn. $100-150 \mathrm{ft}$.

43. P. - Clanbrasiliana, $1-4 \mathrm{ft}$.

44. P. - elegans, 1-3 ft.

45. P. — - stricta, 1-4 ft.
46. I'. Picea fuliis rariegatis.

47. P. - Lemoniana.

48. P. - monstrosa.

49. P. - viminalis.

50. P. - Carpatica.

51. P. - tenuifolia.

52. P. — gigantea.

53. P. - mucronata.

*54. P. oborata, tree.

*55. P. Schrenkiana, tree.

56. P. Jezoensis, $l^{2}$ ? 100-120 ft.

*57. P. polita.

58. P. Nhhutrow, 50-100 ft.

59. P. Morinda, $50 \mathrm{ft}$

*60. P.:Sitclıensis.

Species recently introduced.

60a. P. Ajanensi3.

60ל. P. Techugatskoi.

\section{Doubtful Species, from Oregon (Lewis and Clark.)}

Abies aromatica.

- falcata.

- heterophylla.
Abies microphylla.

- mucronata.

— trigona.

The whole of this group, composed of the clan of Spruces, assume the form of a spiry cone or pyramid. P. Menziesii, nigra, Picea, and K/utrow are rather quick growing trees. The branches are more or less horizontal, with pendulous branchlets; in some sorts the branches, though at first borizontal, become depressed, with slightly raised points; and in $\mathbf{5 8}$ the branches are horizontal with drooping points and branchlets, presenting a very graceful appearance. $P$. Jezoensis is a native of China, and is described by Mr. Fortune as a singularly graceful tree. The foliage of $35,39,42,53$ is a dark green ; of 56 a rivid grcen ; of 41 , is a pale grecn; and $32,33,36$, of a white glaucous; and 58,59 , of a pale glaucous green. $P$. Jezoensis is said to retain its leares for seven years ; $P$. Menziesii often loses part of its fuligge during the first year. The inajority of this group will thrire well on inferior lands, in poor clays and boggy soils; but they luxuriate in porous soils, in a moist mountain climate, and come to perfection at higher altitudes than almost all others. The Himalayan species, Khutrow and Morinda, require stro zg loamy soils; when planted in warm sunny situations, in dry soils, 
they are occasionally iujured by spring frosts : in slinded and northern exposures they appear quite lıardy. P. nigra, Picea, and Menzicsii afford the best tinber: P. nigra and Picea, with some others, form ornanental hedges, and when plinsted thickly, and tonped down to four or fire feet from the ground, afford excellent corer for game.

\section{Pixus-Group 4. Larix, Litrclies.}

(Cones small and erect. Leaves in bundles, anıual.)

61. P. Daluurica, low tree.

*62. P. leptolepis, tree.

63. P. Ledebourii, tree.

64. P. pendula, 60-100 ft.

65. P. microcarpil, $100 \mathrm{ft}$.

66. P. Larix, $100 \mathrm{ft}$.

67. P. flore albo.
68. P. Larix flure rubro.

69. P. - pemilula.

70. P. - liussica.

71. P. - repens.

72. 1'. Sibirica.

73. P. Griffithiana, 40-60 ft.

The Larelies are all deeiduous trees. They, are not highly ormamental in themselves; yet they impart considerable variety to scenery. $P$. Larix pendula is a gracetul tree; and $P$. pentula, with its few straggling drooping branches, has a somewliat curiutis aspect. The foliage is mostly of a light-green: in 65 it is more visil than in the others. 'The Larches succeed best in an upen, porous soil, where there is a gool natural drainage; in such situations, and witl a moist atmosphere, they are often extremely luxuriant. On close retentive subsoils tluy do not thrive. F. microcarpa will grow vigorously in more swampy soils than any of the others. The common larch is the most valuable exotic timber-tree which we have; and, in farorable circumstances, will attain to perfection at even higher altitudes than the Scoteh Fir does.

\section{Prives.-Group 5. C'edris.}

(Cones large, erect. Leaves in bundles, perennial.)

74. I. Deodara, 100-150 ft.

75. P. - robusta.

76. P. viridis:
77. P. Atlantica, 80-100 ft.

78. P. Cedrus, 60-80 ft.

79. '1'. argentea. .

The whole of this group have a pyramielal form when young, but acquire a broad lienc in mature age. The Deodar, when full grown, is said to have a wice roof-like head, with spreadug branches and weeping branchlets. The Cedars of Atlas and Lubauon have both a strougly marked and characteristic form, in which the primary branches assume an ascendung pusition, and the sacomlary branehes a horizontal and tabulated arrangement. Occasionally the old trees retain their early pyranidal lıbit, the lesser branches still becoming liorizoutai. The foliage of the common cedar is of a dark green; 76 of a light virid 
green; the others are more or less of a light silvery green. The timber of $P$. Deodara is very durable; that of the others is of a very inferior quality. The physiognomy of this group is extremely distiuct, and when well exhibited is highly ornamental.

\section{Prvos-Group 6. Cembra.}

(Cones erect. Leaves in fires, sometimes in fours and sixes.)

"80. P. parviflora, s. tree. $\quad$ 83. P. Cembra humila, slinub.

*81. P. Koraiensis, 10-12 ft. 84. P. - pygmæa, shrub.

82. P. Cembra, 50- $70 \mathrm{ft}$. 85. P. Peuce, $30-40 \mathrm{ft}$.

This group begins the modern genus Pinus, according to the Botan ists who have subdirided the old Linuæan genus. Only P. Cembra and its rarieties have been introduced into this country; the latter are mere bushes. P. Cembra is of an oblongated conical form, and has fiie pale glaucous foliage. It is very widely disseminated, both in the extent. of surface which it corers, and of eleration through which it ranges, in the mountain chains of Central Europe and Torthern Asia. It thrives well in poor soils, at considerable heights, and is a useful timber, as well as an ornamental tree.

\section{PIncs.-Group 7. Strolus.}

\section{(Cones drooping. Leares in fires.)}

86. P. excelsa, $50-100 \mathrm{ft}$.

91. P. monticola, tree.

87. P. Strobus, 50-150 feet.

92. P. Ayacahuite, $100 \mathrm{ft}$.

88. P. - alba.

93. P. Lambertiana, $200 \mathrm{ft}$.

89. P. - brevifolia.

94. P. - brevifolia.

90. P. naua.

The type of this group is $P$. Strobus, the Weymouth Pine. The general form is pyramidal. The branches of 86 are weeping; in 87 they are at first ascending and then spreading. The foliage of 86 is of a pale glaucous tint; in 87 , bluish; in 92 , whitish-green; in 91 , dark glaucous; in 93, rivid grcen color. The leares of $P$. excelsa are above 6 inches long, and of the others about 5 inches. $P$. Lambertiana, which is one of the giants of the North-west Amcrican forests, is said to attain its greatest height in pure sancl. $P$. exoclsa, a Himalayan species; has bcen found to grow well on poor, sandy soils in this country.

\section{Prves.-Group 8. Pseudo-Strobus.}

\section{(Leaves in fires.)}

*95. P. Ehrenbergii, $100 \mathrm{ft}$.

96. P. rudis, h?

97. P. Hartwegii, $h^{2}$
98. P. oocarpa, $s h, 40-50 \mathrm{ft}$.

99. P. oocarpa oocarpoides, $s h$. 100. P. Russelliana, h? tree. 
101. P. Deroniana, $h$ ? $80 \mathrm{ft}$.

102. P. macroplyylla, ho tree.

103. 1'. Acapulcensis, $50 \mathrm{ft}$.

10.4. P. Montezuma, $40 \mathrm{ft}$.

105. P. Lindleyana, trce.

106. P. Grenvillex, $60-80 \mathrm{ft}$.

107. P. Gordoniana, $1 / ? 60-80 \mathrm{ft}$.
108. P. occidentalis, $h \cdot 30-50 \mathrm{ft}$.

109. P. Wincestcriana, $s h, 60-80 \mathrm{ft}$.

110. I'. tenuifolia, $s h$.

111. P. Pseudo-Strobus, $s h$.

112. P. leiophylla, $h$ ?

113. I'. filifulia, $s h$.

114. I'. Orizabse, tree.

This group is almost exclusirely Mexican; it is of recent introduction, and as most of the species are somewhat tencler, nore time must elapse before their general liabits can be accurately known. The Botanists who introduced then do not seem to luave paid much attention to the forms of the trees; but as far as can be judged at present, they are likely to approach the rounded cone, or an irregular, broad, loose habit. The branches of 106 and 113 are large and irregular; of 107, nun;erous in whorls; and of 109 few, strong, irregular, and spreading. The foliage in $100,107,112$, and 114 , is of a light green; in 102, 103, $104,105,109,111$, it is glaucous; and in 106 it is of a dark-green color. The leaves of all the species are extremely long; in $P$. Deconiana and Wincesteriana they are from 12 to 14 inches long; and in P. macrophylla and Gordoniana about 15 or 16 inclies long. The timber of 112 is raluable. The curious, tressy, light-colored foliage of this group makes it very desirable for ornamental purposes. The value of the timber generally has not yct been well ascertained.

\section{Prsus.-Group 9. Tada.}

115. P. Teocote, $100 \mathrm{ft}$.

(Leaves in threes.)

116. P. patula, h?

117. P. - stricta, $h^{9}$

118. P. - macrocarpa, $h$ ?

*119. P. insularis.

120. P. Persica, h.?

121. P. Sinensis, tree.

122. P. longifolia, $s h, 50-80 \mathrm{ft}$.

123. P. Gerardiana, $h$ ? $50 \mathrm{ft}$.

124. P. macrocarpa, $120 \mathrm{ft}$.

Sinclairii, Hort.

Coulteri, Don.
125. P. Sabiniana, $h ? 120 \mathrm{ft}$.

126. P. radiata, $100 \mathrm{ft}$.

12\%. P. tuberculata, $100 \mathrm{ft}$.

128. P. Benthaṇiana, $200 \mathrm{ft}$.

129. P. insignis, $60-100 \mathrm{ft}$.

130. P. ponderosa, 80-100 ft.

131. $P$. scrotina, $40 \mathrm{ft}$.

132. P. rigida, $70-80 \mathrm{ft}$.

133. P. Treda, $80 \mathrm{ft}$.

134. P. australis, h?

135. P. Canariensis, $s h$.

136. P. Bungeana.

In this group the forms range from the ronuded cone to the broad, irregular liead. The branches exhibit peculiarities of habit; those of 124, 128 are large, spreading, and irregular ; of 123, horizontal, spreading, and twisted; of 125 , lonse aud robust; of 130 , few and horizontal, 
in regular whorls; of 129 and 132 , densely set. The color of 125 is a silvery green; of 124, glaucous; of $115,116,123$, light-green; of 121 and 129 , rivid green ; and of $126,128,130$, dark green. The length of the leaves varies, generally from 2 to 8 inches, but in $124,125,128,130$, it ranges from 10 to 12 inclies. P. insignis, Saliniana, macroctrpa, and ponderosa are of very rapid growth. P. Tada, radiata, and tuberculata stand the sea-breeze well in their native countries, and are expected to prove aequisitions to parks near the sea-eonst in the United Kingdom. $P$. Sabiniana requires a rich loan; Gerardiana thrives among rocks and crags ; Tedda in very barren ground, but attains its greatest perfection in swampy soils. $P$. insignis and rigida afford effeetive shelter. The timber of $P$.rigida is valuable, and that of $P$.ponderosa is expeeted to prove so. The light silvery eolor of $P$. Sabiniana and macrocarpa will be as marked in ornamental seenery, during the whole year, as the summer garb of the Huntingrion willow; and the light green of $P$. Teocote, patula, and Gerardiana, as that of the summer greens of the decirluous trees.

Prvus.-Group 10. Pinaster.

(Leares in pairs, rarely in threes.)

137. P. pungens, $100 \mathrm{ft}$.

138. P. murieata, $40 \mathrm{ft}$.

139. P. inops, $40-50 \mathrm{ft}$.

140. P. mitis, $50-60 \mathrm{ft}$.

141. P. variabilis, $30-40 \mathrm{ft}$.

142. P. Pinaster, $50-60 \mathrm{ft}$.

143. P. - Esearena.

144. P. - Lemoniana.

145. P. - minor.

146. P. variegata.

117. P. Pumilio, $5-10 \mathrm{ft}$ :

148. P, uneinata, 30-50 ft.

$$
\text { Mugho, Lindl. }
$$

149. P. rotundata.'

150. P. - Inmilis.

151. P. - obliqun.

152. P. sylrestris, $40-80 \mathrm{ft}$.

153. P. - rubra, $60-70 \mathrm{ft}$.

154. P. - argentea.

155. P. sylvestris monophylla.

156. P. — Haganoviensis.
157. P. - Altaica.

158. P. - globosa.

159. P. - tortuosa.

* 160. P. densiflora, $40 \mathrm{ft}$.

161. P. Massoniank, $s h$.

*162. P. Merkusii, $100 \mathrm{ft}$.

163. P. Banksiana, $40 \mathrm{ft}$.

164. P. resinosa, 80 it.

165. P. Laricio, 100-150 ft.

166. P. - Calabrica.

167. P. — Caramanica.

168. P. — subviridis.

169. P. — pygmæa.

170. P. Austriaca, $100-120 \mathrm{ft}$.

171. P. Pyrenaica, $60-70 \mathrm{ft}$.

172. P. Pallasiana, $60-80 \mathrm{ft}$.

Taurica, Hort.

173. P. Halapensis, $h$ ? $30-40 \mathrm{ft}$.

174. P. maratima, $h$ ?

175. P. Brutea, $h$ ?

All the trees of this group have more or less pyramidal forms when young; many of them hare, or approach to, the form of a rounded 
cone when they have attained a considerable size; but $137,161,170$ acquire broad-formed heads; the pyramidal form is retained by $14 \%$, 165,172 ; some, as 147,148 , are seldom more than bushes. The branches of $139,163,173$, are long and pendulous; of 161,175 , spreading; those of $164,165,171$, hare a loose, and 147 a crecping labit. The color in 154 is silvery; in 161 , glaucous; in 173,175 , light green ; is 152 , a sumber glaucous green; and in the others, shades of dark green. The whole of them thrire in inferior soils; 139,173 , in dry, barren, and sandy soils; 163, 165, 170, 172, in good sandy soils; but the last three in a variety of other soils, if not wet. $P$. variabilis and Pinaster, with its rarieties, in sandy soils along the sea-coast, but not in wet or calcareuls soils. P. Laricio is of rery ripid growth; $P$. Pinaster, Auslriaca, Pyrenaica, and Pallasiana are also rapidly-growing treek. The timber of $138,152,153,164,165,170,171,175$, is of superior qual. ity. P. Pumilio and uncinata form good corers for game; they will grow in very elerated situations. Many of the members of this group supply the landscape-gardener with the means of imparting depth of shade to scenery.

$$
\text { Pixts-Group 11. Pinca. }
$$

(Leaves in pairs, rarely in threes.)

176. P. Pinea, $h$ ? $50-60 \mathrm{ft}$ 179. P. Fremontiana, $h$ ? $20 \mathrm{ft}$.

177. P. — Cretica, $s h, 40-50 \mathrm{ft}$. 180. P. cembroides, $h$ ?

178. P. - fragilis, $s h$. 181. P. Llaveana, $h$ ?

This group is a sinall one; and from their impatience of eold in this country, its members scldon rise abore the size of large bushes. Pinea and its rarieties have a peculiarly flat head, and are of a dark green color. The foliage of 179 and 181 is glaucous, and that of 180 a virid green. They nay be planted as shrubs in sheltered places.

P. Arabica.

Doultful Species.

P. Finlaysoniana.

Srgorder II. ARAUCARIEAE.

Gen.1. ARAUCARIA.

1. A. imbricata, $100 \mathrm{ft}$.

This remarkable tree is a native of the southern mountains of Chili, and is quite hardy. It is to be regretted that its congeners, some of which are not less beautiful, are not sufficiently robust to bear our climate out of doors. From the peeuliarly rigid and apparently artificial labit of A. imbricula, and its singular dark-green foliage, it has alrays, eince its introduction, been a special farorite. Intrinsically a fine 
object, it is extremely effective in ornamental scenery, in the way of contrast to the more massive and less marked forms of other trees and shrubs. At the same time, it must be admitted that it does not group very well by itself.

\section{Sudorder III. CUNNINGHAMIEA.}

Gen. 1. CUNNINGHAMIA.

1. C. Sinensis, $s h, 40-50 \mathrm{ft}$.

\section{Gen. 2. SEQUOIA.}
1. S. gigantea, $200 \mathrm{ft}$.
2. S. sempervirens.

Cunninghamia Sinensis is not a very ornamental tree when young, but it improves in this respeet as it inereases in age. It is, probably, however, always inferior to the Araucaria. Sequoia gigantea is a remarkable evergreen tree from California, of rapid growth, and requiring shelter and a somewhat moist elimate. In exposed situations, its fine foliage is liable to be injured by winds. The branches alternate round the trunk, and as they are short they give the tree an upright form. We suspeet that at present there is some confusion, or at least indistinctness of riew, among botanists regarding the two species.

\section{ORdER III. PODOCARPEA.}

Gen. 1. PODOCARPUS.

1. P. nubigena, h? Patagonia.

Gen. 2. MICROCACHRYS.

1. M. tetragona, 15-20 ft. Van Dieman's Land.

Gen. 3. SAXE-GOTHEA.

1. S. conspicua, $30 \mathrm{ft}$. Patagonia.

Of this fine Natural Order there are, unfortunately, of the species introduced into this country, very few hardy. We have given the abore in the hope that, as two have proved sufficiently robust to stand our climate, the others will do so also. Saxe-Gothea, or Prince Albert's Yew, has searcely been definitely located, as yet, in the Natural System; but we have ventured to place it in this Order. It promises to be as vaiuable addition to our ornamental trees. 


\title{
Order IV. TAXINEAE.
}

\author{
Gen. 1. SALISBURIA.
}

1. S. adiantifolia, $10-30 \mathrm{ft}$.

Where Salisburia, or the Maiden-hair tree, attains a considerable size, it assumes a broad form; but it is seldom found in that statc, except in the southern climates of Great Britain, in rich, deep soils and warm subsoils. Its light-green leares, which are generally much divided and furnished with conspicuous nerres, are its chicf peculiarity, and reuder it very unlike any other tree in cultivation.

Gen. 2. CEPHALOTAXUS.
1. C. pedunculata, tree.
4. C. umbraculifera.
2. C. drupacea, tree.
5. C. Fortuni.
3. C. tardiva.

These are fine cvergreen trees : 1 is a large tree, with slender weeping branclies, and 3 has an upright habit. The foliage is of a dark green, with a whitish glaucous tiut underneath, in 3 and 4 . The leaves, which in all the species rescmble those of the yew, are in 5 three or four inches loug.

\section{Gell. 3. TORREYA.}
1. T. taxifolia, $20 \mathrm{ft}$.
3. T. nucifera, $30-40 \mathrm{ft}$.
2. T. Humboldti, tree.

The Torreyas are yew-like trees. T. taxifolia has vivid green leaves, which are glaucous underneatl.

\section{Gen. 4. TAXUS.}

1. T. baccata, $30-40 \mathrm{ft}$.

2. T. - sparsifolia.

3. '1. — argentea.

4. T. - aurea.

5. T. Dovastoui.

6. T. - pyramidalis.

ว. T. - erecta.

8. T. elegantissima.
9. '1. baccata lutea.

10. 'T. fastigiata, Irish, 5-15 ft.

11. 'T. variegata.

12. ' $\mathrm{T}$. Canadensis, $4-6 \mathrm{ft}$

+13. T. cuspidata.

*14. T. TVallichiama.

*15. T. glouosa.

16. T. adprcssa.

The common yew (1) is, in open situations, a broad, spreading, brancling tree; in a close wood it grows more erect. In 5 the branches are penduluus, and in 7 erect. In 6 the form is pyramidal; the Irish yew (10) is of a well-kuown upright form. T' Canadensis is of less rigorous growth than the common yew, with slender spicarling branches, 
and leares of a. reddish tinge. The foliage of yews is generally of a dark green. Mr. Barron, of Elvaston Castle, greatly commends $\mathbf{4}$ as the most effective yellow erergreen known. Yews are extremely nseful in pleasure-gronuds, as low trees and shrubs, and make good undergrowths in the woods of the park, especially where a depth of shade is required. It must never be forgotten that they are poisonous to horses and cattle.

Tine Effects of Climrate.-The climate of the locality will, in great measure, limit the number of species in the pinetum, or at least the number of those which may be expected to attain a considerable degree of perfection. Of the hardiness of certain recentlyintroduced sorts some doubts may be reasonably entertained, except, perhaps, in the case of such as are known to thrive in climates of equal or greater severity than our own. In the southern parts of England and Ireland, most, perhaps all, of those marked sub-hardy may succeed; but in less favored localities, they will exist only as specimens preserred with difficulty. Those marked doubtfin will also become inferior trees and shrubs. In the higher and more northern regions of the conntry, the sub-hardy kinds must increase in number, and so proportionally diminish the extent of the members of the pinetum. The climate of the south of England and Ireland, and of the wrest coast and islands of Scotland, where there is little frost, we can not doubt, will prove most snitable to the group Pseudo-Strobus, which is the most delicate of all the divisions of the pine tribe. At the same time, there are some countervailing circumstances in elevated localities. Many of the pines are natives of mountainous regions, and therefore find something 
congenial in our hill climates. We donbt not that certain species, which do not succed in the low grounds, will be found to do better in the ligher districts. The principal reasons of their failure in the warmer loealities are, that the season of growth being mululy protracted, they do not sufficiently ripen their ammual shoots before the arrival of the autumual frosts; and further, even where the wood has been well ripened, there are not unfrequently, in these localities, long periods of mild growing weather, in winter and early spring, which excite vegetation long before the rernal frosts have passed away; in either case, the young wood is more or less destroyed. In hill climates, again, there is no time for a second or protracted growth in the end of summer, and the young shoots, though shorter, are better ripened than in the low country; besides, the spring is comparatively short; the transition from winter to summer is generally rapid, and so the plants escape with little injury. If there is a constitutional tendency in any plants to a protracted growth, there is little prubability of their ever proving hardy; still, this tendency is alway's found to be greatest when the plants are young, and therefore no one should be discouraged even by repented failures in such cases. II. Graham, Esq., of Belstane, whose judicious and persevering efforts in acclimatizing plants have met with deserved suceess, when furnishing his pinetum, at his residence about twelve miles from Edinburgh ind more than seven hundred feet above the level of the sea, found that plants procured from the nurseries of Paris, London, and Ediuburgh, continued tender for the first two or three years, till their constitution harl become attempered to the place, 
and they had outlived the period of irregular growth. To Mr. Graham we are indebted for some of the indications of hardiness given in the foregoing enumeration of species. We have also been favored with similar information by George Patton, Esq., of The Carnies, a zealous and successful eultivator of pines, whose pinetum, in the sub-alpine country west of Pertl, affords abundant corroborative proof of the views we have expressed. In our remarks appended to the sections Abies and Pirea, we mentioned several species whose young shoots are liable to be injured by spring frosts, and other sorts might easily be added to the number. Such injuries generally occur when they are planted in warm, sunny situations, and arise from their being, at the time, in advance of the average climate of the place. These results seldom oceur when they grow on ground sloping toward the north, or where they are little exposed to the sun in spring. The decrease of injury from late frosts, as the tree increases in age and size, is strongly marked in the Cephalonian and silver firs. It remains to be added, that the power of many species to resist the severities of our climate has still to be tested by more rigorous winters and springs than we have experienced of late years.

Soil of this Prnetum.-Generally speaking, pines do not require deep or rich soils, and they sueceed best on ground of loose texture, lying on subsoils through which water percolates freely. Some spruess thrive in comparatively poor clayey soils; and along with Larix microcarpa and Pinus Tada, grow vigorously in moist or even swampy ground; but these are exceptions to the general rule. Others, such as $P$. Lambertiana, Pinaster, australis, excelsa, and a few more, 
flourish greatly in dry, sandy soils; the first two seem to luxuriate in deep sand. The group Alies generally requires richer land than the other's to bring them to perfection. The whole fanily, howerer, will do well in the soil indicated above. Where the land is naturally of a close, clayey texture, the growth of the young trees will be promoted by the removal of the earth, for each plant, to the extent of six or ten feet in diameter and eighteen inches deep, its place being supplied by earth of a more suitable quality. In refilling the pit thus made, the new surface should be raised in the form of a hillock, from six to nine inches above the old level; allowance, besides, being made for subsidence. In retentive ground, these pits should be properly drained, otherwise they will become receptacles of water, to the serious detriment of the young trees. In poor soils, the same method of pitting may be employed for those species which require richer food. Trenching to the depth of eighteen inches is a useful but rather expensire preparation for the pinetum; where it is adopted, as it may sometimes be by zealous eultivators, care should be taken not to bury the surface-soil under the lower and inferior soil, or subsoil.

Early Celitivation of the Plants.-All pines should, if possible, be raised from seed. Seedling plants invariably grow most vigorously from the first, and form ultimately the most handsome trees. In the case of new and recently-introduced sorts, seed is often procured with difficulty; and therefore, propagators have frequently had recourse to gratts and cuttings. Uncxpected success has often attended both methods of propagation. We have already mentioned (p. 145) 
that we had grafted P. Morinda on common sprues, at Hopetoun, and that they are now fine trees. Mr. Barron, of Elvaston, seems to have been equally successful with the deodar on the common celar: At present, indeed, P.nolilis, grandis, and some otlier species, and many of the singular varieties, can liardly be proeured from nurseries in any other form. In grafting, the stock should be of a vigorous and allied species. We found that while Morinda flourished on the spruce, it merely lived and dwindled on the Scoteh fir. The scion should be taken, if possible, from the point of the leading shoot of an upper lateral branch; inattention to this precaution has been the cause of many failures in grafting. We hare seen good plants of $P$. Deodara and Morinda formed from cuttings; and we should suppose that the same method might succeed with varions other of the small-lenved species. In most plants, howerer, propagated by grafts or cuttings, some attention and skill is required, to throw, by judicions proning, the main strength of the tree toward the leading shoot. After all, seedlings will always be justly preferred. Hitherto many young pines have been grown in pots. This has arisen partly from the great demand for rare species, partly fiom the idea, which is more or less correct, that some of these are tender when young, and partly also from the facility with which, when grown in pots, they can be transmitted to distant parts of the comntry at any season. These supposed advantages are often sadly connterbalanced by the early contortion of the roots, and the consequent overthrow of the trees, in later year's, by strong winds, a disaster by far too common iu pinetums. When put, at first, into very small pots - 
which are often not more than two inches in diameter-the roots become matted and twisted round the interior of the pot; and this process nay be repeated at each successive shifting, till the roots have assumed the form of a bird's nest, and the upper part of the plants have been in a great measure stunted. They are frequently transferred to the open ground without any efficient attempts being made to spread out the roots on the surface; and when the separation of the roots is resorted to, it may be so violent as to give a considerable check to the growth, for which reason it is often employed with reluctance; indeed, in old potgrown plants, whose roots have acquired a firm set, the operation may be impossible; in which case it will be more satisfactory to throw them away than to plant them, for they are almost sure to be upset by the wind when they have attained the height of fifteen or trenty feet. Most of the pine tribe have few or no tap roots. They spread their principal roots all ronnd near the surface of the soil; and these roots, being more or less at right angles to the trunk, according to the slope of the ground, afford the tree a primary rest or support, independently of the hold which, as roots, they take of the soil. Of course this adrantage is greatly lessened, if not wholly lost, by pot-culture. Nevertheless, this mode of propagation can not be wholly discontinued. Some pines are undeniably tender while young. The facility with which plants can be turned out of pots with good balls, is of considerable value. For these reasons, this method of cultivation should be, if possible, improved, and its disadvantages sedulously remedied. We would recommend the employment of wider and shallower pots than those in 
common use-say six inches in diameter by four in depth for the first potting, and ten by six for the second. Perhaps it would be better to adopt the larger pots at once, as these would allow the roots to spread, and prevent the corkserew set, which is the bane of potculture. Another error is, that pines are generally retained too long in pots, being kept during summer in some back region or shaded fiame in a garden or nursery, to save the trouble of frequent watering; and the result of this treatment is almost invariably a stunted habit, which is very difficult to overcome. Pines in pots should be encouraged to grow rigorously, and should be put out as soon as they are able to bear the open air. It is right to add, that nurserymen have met with unmerited reproach in regard to the smallpot culture of pines. We have examined few private collections in which the system was not equally prevalent.

Planting of the Pinetum. - As a general rule, the best season for planting pines is in October. If the plants are in pots, or are growing in the vicinity of their pelmanent site, and have been well prepared by frequent removals, they. may be successfully transplanted during moist weather in April or in the beginning of May. At each of these seasons the soil should be thoroughly saturated with water, when the operation of planting is two-thirds completed. The plants should not be placed deeper in the earth than they were previously; and it contributes much to the early prosperity of the plant that the roots be covered with leaf-mould or well-rotted, turfy loam. It is injudicious to stake the trees any further than may be necessary to prevent windshaking, for a year or two. WVhile the 
young plants are tender, and require protection in winter, three or four stakes driven into the ground, and rising a few inches above the top of the trec, and corered with matting or spruce-fir branches, will generally afford sufticient shelter. Some protect the leading shoot by a bell-glass, or cap of felt, supported in the same way. For subsequent cultiration, little more is required than the clearing away of long grass and weeds from the young plants, and the thinning out of nurses, where that mode of protection has been employed.

Prunng of Pines.-The fir tribe, when grown in close plantations, require little or no pruning. In the pinetum, a moderate application of the knife is bene. ficial to many of the species. Owing to differences of climate, or variation in the pressure of the atmosphere from differences of altitude, some of the sorts, which are tall trees in their own countries, are apt to grow bushy with us; or, from accidental circumstances, some of the higher lateral branches may show a disposition to compete with the leading shoot. In all these cases, the thinning-ont of the branches, especially the small ones, and the foreshortening of those which are acquiring an excessive or irregular luxuriance, will be found useful, particularly in the Cedrus, Picea, and Abies groups. The object kept in view shonld be to direct the flow of sap to the head and shoulders of the tree; but it ought to be regarded as a first principle, that by pruning the natural form of growth is to be promoted, and not constrained into any thing artificial. Mr. M'Nab, of the Edinburgh Botanic Garden, who has inherited and acquired much experimental knowledge in this department of arboriculture, has found 
that the pruning of trees in the pinetum is most suc. cessfully performed in July. This result indicates that the proper time for this work is when, the seasoll's growth being far advaneed, and the flow of sap abated, there is little danger of an excessige exudation of resinous matter from the wounds. We may add, that it is generally inexpedient to take off large limbs from this elass of trees.

Decorative Treatuent of tire Pinetum.-The pinetum, when planted separately, as it is desirable it should be, is best arranged in groups, with irregular lawns passing between them; the larger trees occupying the leading positions, and those of lower growth or shrubby character filling up the secondary places. The groups shonld be made up of the generic and subgeneric divisions, as given in our enumeration of the species. In the genera Juniperus and Pinus, some of the sub-generic sections may require to be further broken down, otherwise many of the species must be so placed that they will have enongh of room only for their partial derelopment; or they must be dotted out at such distances as nearly to ungroup the whole. Where there is a liberal allowance of ground to be occupied by the pinetum, we should be disposed to recommend that the groups should be constructed with prineipal trces, arranged on striet botanical principles, but planted very sparsely; and that the intervals between these main trees should be filled up witl interesting duplicates of the same or allied species, to act as nurses, or to be temporary occupants, till the whole space is required by the others. This plan, of course, implies a continued and resolute thinning-out, as the pinetum advances to maturity. We do not think it 
needful to say any thing of the position of the groups relatively to each other, as our remarks on the decorative treatment of the arboretum will, mutatis mutandis, apply to the pinetum.

In our remarks appended to the lists of species, we hare noticed the colors of the foliage and the forms of many of the trees and shrubs there enmmerated, to aid the pianter in making his selection and fixing his subordinate arrangements. The effect of the various colors is an element which must be taken into careful consideration. Hitherto, the species employed have been principally those with dark-colored foliage-a property extremely raluable in producing deptlis of shade, and in affording contrasts where such effects are necessary; but which, in many places and positions, both in the pinetum and in the pleasure-ground generally, has imparted a gloomy expression, particu. larly when the masses are mbroken and unrelieved. When, then, the pinetum is planted on a level surface, it is peculiarly needful, in order to lighten the somber effeet incident to fir-woods with dark-colored foliage, that sone of the lawns between the groups should be of considerable width, to afford effective breadths of light in eontrast with the depth of shade yielded $b y$ these deep-tinted and embowering trees. There shonld, besides, be a free use of the species exhibiting silvery, glaucons, and rivid greens; and the duplieates and nurses, as suggested above, should be principally of this character. It may not be out of place to remark, that the somber effect to which we are now alluding has probably been the cause of the rery sparing employment of the Coniferce in parks and pleasuregrounds generally, and of the corresponding excess in 
the use of deciduous trees. This is an error to be regretted, and, if possible, to be corrected. By the judicious intermixture of firs possessed of light and vivid green foliage, a considerable amonnt of evergreen clothing might be given to the woods, without saddening, but rather, on the contrary, enlivening, particularly in winter, the general features of the place. The effect of light-green foliage may be observed during summer in the young shoots of the Scotch, silver, and spruce firs, which, at that season, when seen from a distance, are not easily distinguished from their deciduous neighbors, except from their dissimilarity of form. As to the general effects of form, in the fir tribe, the reader is referred to our chapter "On the Ornamental Character of Trees."

The necessary expansion of the lawns in a regular and well-appointed pinetum, tends to discourage some proprietors from allowing the ample space which is requisite for their formation; and where land is very valuable, we can not wonder that it should be so. In hilly or upland districts, there is often much more space than is required for this purpose thrown away on useless or promiscuous woods of little character or value. In such cases, want of room is no valid objection. But even when his territory is limited, the pinefancier need not be wholly discouraged, as he may have a considerable collection of his farorite trees, and derive much pleasure from their cultivation, if he is content with the opportunity of admiring them when they are young, or during the first twenty or twentyfive years of their growth; but after that period, he may expect to see them disfigmring and destroying each other by their mutual pressure, or he must be 
prepared to exhibit the decision of the sailor who cuts down one mast to preserve the others. The misfortune is, that the pine-grower does not feel his own life in danger while his trees are gradually perishing, and so can not steel his mind to the requisite use of the axe. We think it possible, to arrange a small pinetum so that when the sorrowtil period of extirpation has arrived, such trees as $P$. nobilis, Deodara, Douglasii, Atlantica, Lambertiana, Benthamiana, etc., might be left in their glory, at well-spaced intervals; while $P$. Canadensis, Abies, Picea, Cembra, and other of the commoner sorts might be swept away. We question, however, whether the actual planter would ever have the heart to carry out such a plan. Another alternative is to scatter the Conifers, in separate groups, through the grounds, as a main part of the evergreen trees of the place. Pines of varied character are not so deficient in calmness and breadth of effect, as are most deciduous trees in similar circumstances. Or they might be so distributed as to compose what may be termed a shrubbery pinetum; that is, they might be grouped on lawns, with the groups at distances suitable for trees and shrubs from fifteen to twentyfive feet high, so as to form a shrubbery much more interesting than those planted in the usual commonplace way. The Pinacea, even when only a few feet in height, have forms which, in combination with their evergreen foliage, exhibit a most decided character at all seasons. The shrubbery pinetum is an interesting decoration, not only for small residences, but for more extensive pleasure-grounds in the higher parts of the country, where many shrubs do not thrive; but in this 
case, the selection must be made from the hardier species of pines.

Where a piece of unoccupied ground can not be allotterl as space for a regular and formal pinetum, constructed on scientific principles, a considerable collection of pines may be formed in the woods, in which much scenic beauty may be displayed, and all the interest arising from indiridual specimens may be preserved. This plan can be most easily and successfully: executed when the trees, already planted, have not attaned a greater age than trenty or thirty years. When the woods are olcler, much wider spaces inust be cleared out. In either case, however, a sufficient number of the old trees must be removed to allow to the new groups or individual plants a suitable breadth of air and light from abore. When this is not attended to, the young trees will be exccssirely drawn up, and so lose their natmal charncters. For the same reason, the old trees should be early, but gradually thinned out, in order that the pines may be inured to the climate of their position. To insure success, the ground should be trenched. to prepre it for the reception of the plants, and to cut off the roots of such of the old trees as are likely to interfere with the new comers. A little flesh soil, also, employed in planting, will be adrantagreons. If large pits are opened and filled up ritl new soil, the directions giren above must be follorred. We are disposed to think that a pinetum in the woods, when well executed, is one of the most pro. pitions arrangements for the growth of the young pines, and among the most graceful in point of scenic character that can be formed.

Note. With our recent acquisitions on the Pacific 
const, the United States might boast a pinetum more conprehensive in variety, and imposing in character, than any country on the globe. In a central position, with a variety of suil, and under shillful management, it could embrace the evergreens of almost erery known land. Our general goverment em do.nothing better to advance our progress in vegetable physiolugy, than by its anthority, and under a liberal appropriation, to establish a National arboretum, and pinetum, near Washington, which shall be creditable to its munificence, and show the rast forest wealth which our country may contain. It would be a work of enduring beauty and usefulness, as creditable to the wisdom of our national legislature as indicative of the increasing goorl taste of the people--Ev. 



\section{I $\mathrm{NDEX}$.}

American garden, 91

Approach, 52. Direction of, 5.).

Site of entrance of, 56 . Line through the Park, 60. Gates on, 63. T'ermination of, 64. Roadway of, 6.5. Decuration of, 6i. Villa, 2it.

Approach, the Fine, 70.

Arcucarin, 317.

Arboretnm, 303. General Luta of, 305. Scientific treatment of, 305. Principles of arrangement, 308. Srnopsis of orders and genera, 309. Conspectus, 319. Application of principles, 322. Trunsference of system to the ground, 323. Decorative treatinent, 326. Soils and surfaces, 3æ8. Arturetum in the pleasure-greunds, 330 . In the woods, 331.

Artificial style, 131.

Asb, 133. Weeping ashl, 143.

Avenue, $69,132$.

Deech, 139.

Belts, 127.

Birch, weeping, 147 .

Biota, 333.

Botanic Gardens, 231. Special purposest of, 233. Jasing-out of, 237 .
Botanical Mruseum, 236.

Callitris, 338.

Cedar of Lebanon, 139, 343; of Mutunt Atlas, 313. Deodar, 141.

Cephlatotaxns, 319.

Chameectparis, 339.

Chestmut, Spanish,_Irvis-, 139.

Circles, 127.

Clump, $11 \%$.

Colors, Table of, 153. Variation of, 15.4. Of trees in winter, 155.

Colors in the Pinetum, 337, 359.

Conserfatory, 45, 268.

Cryptomeria, 3.10.

Cunninghamia, 340.

Ciziressus, Species of, 339.

Cypress, upright, 146, 339 . Chinose neeping, 148.

Dotting system, 123.

Deodar, 141.

Elm, English, and Scotsh or Wycb, 139.

Ediscational Institutions, gardens of, 235.

Evergrcens, plaiting and transplanting of, 177.

Fences, 184. Bonndary, 185. In. ternal, 185. Pleasure-ground, 187. Siallcable iron, 187. Sunk fence, 188. Walls and hedges, 189. 
Firs in the Pinetum, 340. Forms of, 142,365 .

Fitzroya, 339.

Flower-garden, 85. Site of, $8 t^{2}$. Ground-color of. 86 . Parterres in, 88. Mixed flower-garden, 93. - Artistical decoration, 94. Shelter of, 97.

Forms of single trees, 137. Broal round-headed, 138. Conical, 142. Upright or oblongated, 146. Pendulous, 147. In the Pinetum, 337.

Forms of trees in combination, 157.

Round-hcaded, 157. Conical, 158. Intermingling of, 160 .

Forcing garden, 212.

Forcing llouses, 213.

Fruit garden, 211.

Gates, style of, 58. On the principal approach, 63.

Glyptostrobus, 340 .

Green-houses, 214, 268.

Ground, natural character, 109. Acquired character, 111.

Group, 116.

Grouping of plantations, 121.

Head of lake, 194.

Holly, 142.

Horticultural Gardens, 242. Laying-out of, 245. Muscum, 249. House, 13. Site of, 14. Shelter of, 20. Position in the park, 22 . Style of, 28, 265. Arrangement of interior, 42. Supply of water for, 19. Drainage, 18.

Ilex, 140.

Islauds, 194.

Jet fountains, 199.

Juniperus, 337.

Kitchen-garden, relatious of, 203.
Site, 2ij4. Druinage, 205. Soil, 20\%. Fo!n, 208. Walls, 210. Villa, 276.

Lake, artificial, 19.

Larch, 145. In P'meum, 343.

Landseape gadening compared with landscape painting, 287. Its processes partly tentatire, 293.

Landscape, composition of, in the pleasure-grounds, 75 .

Laurels, 83, 85.

Lawns, formation of, 102.

Libocedrus, 338.

Lime-trec, 139.

Lodge, 58.

Microcachrys, 348.

Mass of Wood, 117.

Oak, 139. Evergreen, 140.

Offices attached to the honse, 49. Ornamental characters of trees, 135. Of single trees, 137. Of trees in combination, 157 . In the Pinetum, 337.

Park, 105. Unity of, 106. Natural character of the ground, 109. Acquired character, 111. Planting in, 112. Surfaces to be planted, 113. Arrangenent of woods, 116.

Park, public, 215. Park villa, 284. Parterre, 88.

Pines, forms of. 143 . In the Pingtum, 337.

Pinetum, 333. Encilicher's arrangement, 335. Synopsis of genera, 336 . I ist of genera and species, witl remarks, 337. Effect of climate on, 350 . Soils, 35\%. Early cultivation of plants, 353. Pot culture, 354. Planting 
of, 356. Proming of pines, 357. Decoratire treatment, 3.38 . Grouping, 358. Distributinus of colors, 359. Lawns, 360 .

Pinus Alies, 341. Codms, 343. Combra, 31. Larix, 313 . Jinaster, 346. Pinea, 347. Pscudo-Strolues. 314. Strobes, 344. Touga, 340 .

Plans, itility of, 296.

Plant-houses, 91, 238, 248.

Plantations, outlines of, 125.

Planting, 166. "Ireparation of the ground, 166. Of forest trees, 168. Pitting, 169. Of evergreeus, 177.

Pleasure-grounds, 73. Planting in, 99. Walks in, 100. Villa, 281.

Podocarpus, 348

Poplars, 146, 161

Pruning, 170.

Public park, 215. Site of, 218. Laying-out of, 219.

Rivers, artificial, 198.

Roads, 65,260 . Through plantations, 168. Secondary roads, 66.

Rockworks, 96 .

Rosary, 90.

Salisburia, 349.

Saxe-Gothea, 348.

Seclusion, 112, 273.

Sequoia, 3:8.

Shelter of house, 20.

Site of the house, 14; 19, 25, 28 .

Stable-court, 49.

Stairs, 83.

Statues, 95.

Street gardens. 228.

Sycamore or Maple, 138.

Synopsis of Natural Orders and genera for Arboretum, 309. i'able of temperntures of soil, 181 . Taxodium, 3:10.

Taxus, 349.

Terraces, 78. Walls uf, 80. Grass slopes of, EL. Banks and shrubs on, 82. Stairs of, 83. Upper - surfaces of, 8.1.

Thinning of trees, $17 \%$.

Thuia, 339.

Thuiopsis, 339.

Torreyu, 349 .

'Transplanting of trees, 173. Of evergreens, $17 \%$.

Unity of the park, 106.

Vases, 84, 94.

Villa, 255. Locality of, 257. Site, 259. Roads to, 260. P'osition of the house, 201. Style and arrangement of the house, 265 . Laying-ont of the gromels, 272. Seclusion, 273. The :1pproach, 274. Kitchen-garden, 276 . Trees and slrubs, 278. Water, 280 . The leading varietics of villa scenery, 231. The pleasureground villa, 331. The park rilla, 234 .

Walks, 83, 87, 100. Formation, 101. Water, supply of, for the house, 19 . Water, ornamental, 191. Artificial lake, 191. Islands in, 194. Head of lake, 19. Artificinl rivers, 198. Jet fonntains, 199. Water as an ornament in public parks, 222. Villa, 280.

Willow, weeping, 147.

Wire fences, 64, 187, 285.

Yew, 140. Irish yew, 146. In Pinetuu, 319.

Zoological gardeus, 2\$1. 



\title{
All the Books on "this Catalogue sent by mail, to any part of the Union, postage paid
}

\section{B 00 KS FOR THE COUNTRY, PUBLISIIED BY \\ C. M. SAXTON \& CO.,}

\author{
140 PLLTUN STRELT, IEH YORK.
} BUJTABLE FOR

8CHUOL, TOWN, AGR:CULTIRAL, AND PRIVATE LIBRARIES.

\section{Downing's (A. J.) Landscape Gardening.}

$\Lambda$ Treat:se on the Theory and Practice of Landscape Gardenlog. Adapted to North Ancrica, with a slew th the Improvemont of Cuntry Residences, comprising His. terlcal Notices an 1 General Principles of the Art. Directiona fur Laying out Grourids and Arrtnging Plantations, the Description and Cultiration of Harly Trees, Decoration Acompaniments to the 1 onse and Ground, the Formation of Pieces of Artifeisl Water, Flıwer Gardens, etc., with Remarks oa Rural Architecture. Flegantly illuytrated, with a Portrait of the Author. By A. J. Downing. Price \$s 50.

\section{Downing's (A. J.) Rural Essays.}

On Uurticulture, Lardseape Grodening, Rural Arcbitecture, Trees, Agriculture, Frait, with bis Letters from England. Edited, with a Memoir of the Anthor, by Qeorse Win. Curtis, and a letter to his friends by Frederika Bremer; and an elegant steol Purtruit of the Authur. Price \$3.

\section{The Practical Fruit, Flower, and Iritchen Gardener's Com.}

panion, with a Calendar. By Patrick Neilh, LL. D., F. R. S. E., Secretary to the Royal Calelonian IJortlcultural Society. Adapted to the United States, from the four'h elition, reviserl and im[roved by the authır. Edited by G. Emerson, M. D., Editor of ".Iolnson's Farmer's Encyclopedia." With Notes and Additions by R. G. Pardee alther of "Manual of the Strawberry Culture." With illustrations. Price 1.

\section{LInn's (B.) Practical Land Drainer;}

B.jng a Treatise on Draining Land, in which the most approred systems of L rainace are ixp'ainet), and thicir differences and comparative merita discnssed; with fufl Irections for the Cutting and Making of Drsins, with Pemarks upon the var'ols Matcrials of which they may be composed. With many illustrations. Fy D. Munn, Land:capre Gardener. 1'rice 5 J cts.

Elliot's (F. R.) American Fruit-Grower's Guide in Orchard ant Garilen: being a Cumpend of the Jlistory, Mudes of Propagation, Culture, \&c, of Fruit, Trees, and slirubs, with descrlytions of nearly all the rarieties of Fruits clil. tivated in this country; and Nutes of their allaptation to lucalitles, soils, sad a cuid. plete list of Fruits worthy of cultiration. By F. B Elliot, Pumologist. I'rice 1125 
Pardee (R. G.) on Strawberry Culture.

A Complete $M$ autal for the Cultivation of the Stritwerry; with a deseriplion of tis a best varietic3.

Alsu, Notices of the Raspberry, Blackberry, Currant, Guoseberry, and Grape; with directions for their cultivation, and the selection of the best varieties. "Every pron cess here reconmender has been [iroved, the plans of others tried, and the rexult is here given." With a valuable $\Delta$ ppendix, containing tle observatlots and experience of some of the unst sucessful cultivators of these fruits in uir conn'rg. I'rice 5 cents.

\section{Dana's Iiruck Manual for the use of Farmers.}

A Treatise on the Physical and Chemical Properties of Sol's, thic Chemistry of Jianures; including also the subjects of composts, artifizial nıanures und trrigation. A new edition, with a chapter on Bones and Superphospliates.

$\$ 1$.

\section{The Stable Book.}

A Treatise on the Management of Horses, in relation to Stabling, Crooming, Feed. ing, Watering, and Working, Construction of Stables, Ventilation, Appendages of Stables, Mlanagement of the Feet, and Management of Diseased and Defective Horses. By Juhn Stewart, Veterinary Surgeon. With notes and additions adapting it to American Food and Climaie. By A. B. Allen, editor of the American Agricul turist. $\$ I$.

\section{Reemelin's (Cinas.) Vine-dresser's Manual.}

An illustrated trcatise on Vineyards and Wine-making, containung fill instructions as to location and soil ; preparation of ground ; selection and propagation of vines ; the treatment of a young Vineyard, trimming and training the vines; manures and the maling of wine. Cloth, 50 cts.

\section{Bement's (C. N.) Rabbit Fancier.}

A Treatise on the Breeding, Rearing, Feeding and General Iranagement of Rabbits, with remarks upon their diseases and remedies, to which are added full directions for the construction of Hutches, Rablitries, \&c., togcther with recipes for conking and dreseing for the table. Beautifully illustrated. Cloth, $50 \mathrm{cts}$.

\section{The IJorse's Foot, and how to keep it Sound.}

With cuts illustrating the anatomy of the Foot, and containing valualie hinis on shoeing and stable managenent in bealth and in discase. By William Sil'cs. C'oth, 60 cts.

\section{5tcphens' (Fenry) Book of the Farm;}

A Complete Gadic to the Farmer, steward, Plowman, Catteman, Shepherd. Find Worker, and Dairy Maid. By Ifenry Stephens. With Four Itunsted and Fitg

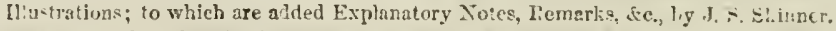
I.eally one of the best books for a Farmer to posses. Cluth, si.

\section{Funsten's (J.F. W.) Elemen!s of Azrucultusal Chemistry} and Geolozy. With a Complete Ans'ytical and Alphabetieal Inlex, atd an dinerien'.

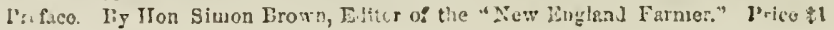


Johnston's (James $\dot{F}$. W.) Catechism of Agricnitural Chemistry and Geslo:y. By Jange F. W. Johnston, M. A, IF. L. SS. L. and L., Unmorary Newber of the linyal $\Lambda$ grientural Snciety of England. and anther of "Lecturcson A gricultural Chentistry and Genlory." Wits an In ruluctlon lig Jihn l'ilki: Norton, M. A., late Professor of $\$$ :ientific Agriculture in Yale College. Wh!t Notes and Ait tius by the Anthor, preparel expressly for this ed tion, and an Appenilix cont-

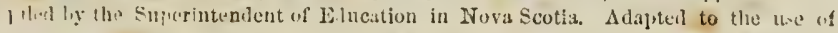
e." 1 is. Price 25 cis.

\section{Jimston's (James T. W.) Agricultural Chemistry.}

botures in bl.e. Apill vation of Chemistry and Geolugy to Agticulture. New edi ion.

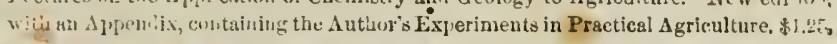

Smith's (C. F. J.) Landseape Gardening, Parks and Pleasure G:ounds. With Practical Notes on Country Residences, Villas, I'ublic Parks, and Garderis. Iiy Charles II. J. Snith, Lindscape Gardener and Garden Archifect, de. Witl. Notes and Additions by Lewis F. Aller, autbor of "Pural Architecture," Se.

The anthr, while engngell in his proficsion for the liat eighteen years, hat often been requesiecl to recomwend a book which might enable jersons to acquire sums a neral knowlerlore of the princip'es of Landscape Gardening.

The object of the present work is to preserve a plain and direct metlod of statementh to be juteiligilile to a l who bare had an orditiary eluention, and to give directions which, it is horet, will be found to be practical by those who bave an allequate knowlediso of conntry atfairs. I'rice $\$ 125$.

\section{Forton's (Juhn P.) Elements of Scientific Agriculture;}

Or, the Cuintexion between science aul the art ot I'rectical Farming. (Prizo Esay of the New York State Agi icultural Socifty.) Ty: Julu P. Nortun, M. A., Professur of scientile Agriculture it. Fule College. Adapted to the use of Schools. Priec 60 cents.

\section{Nash's (J. A.) Progressive Farmar.}

A Sclentific Treatice on Agricultural Chemi-try, the Cenlngy of Agrienlture, on Plants atd $A$ cinus's, Manures and Soils applied to Practical Agriculture; with a Catechism of Scicntific and Practical Agriculturo. Ey J. 1. Naslı. Price 60 cent.

\section{Chorlton's (Wm.) Cold Grapery.}

Frnen direct Amurican Fraclice: leeing a cuncice and detai'ed Treatise on the Cultivrtivil of the Exwtic Grape Vine, under Glass withont artificial heat. By Wm. Chorl. ton, Garkener to J. C. Green, E:q, staten I-latd, N. Y. I'rice s's ceuts.

\section{Allen (J. Fisk) on the Culture of the Grape.}

A Practical Treatise on the Culture and Tratm:nt of the Grape Vine, embrating fts histriry, whis directions for its treatment in the Cuiter States of America, in the open e.r uni under glass otructures, with and without artificial beat. By. J. Fi=k sllen. Irice $\$ 1$.

\section{Ecare (Clement) on the Grape Vine.}

A Practical Treatise on the Cultivation of the Grape Vino on Open Wa!ls, aitli a Decerljtive Accunt of an improved nethod of Planting and Managing the liwh of Grape Vines, By Clement Iloare. Witl an Appendix on the Cultivation of the berwo in the Un"to States. 50 cento. 


\section{Mysteries of Bee-keeping Explained;}

Belng a Compiete Analysis of the whole subject, consisting of the Natural Iiistory of Bees; Directions for Obtaining the greatest amount of Pure Surplus Honey with the least po:sible expence; Remedies for Losses given, and the Science of Luck, fully illustrated; the result of more than twenty jears' experience in extensive B piaries By M. Quinby. Price $\$$ l.

\section{Ameriean Bee-keeper's Iranual;}

Being a Practical Treatise on the IFistory and Domestle Economy of the Honey liee; embraciag a full illustration of the whole sulject, with the most approved methods of managing this Insect, through every branch if its Culture; the result of many years ${ }^{2}$ expetience. liiustrated will many engraings. By T. B. Mluer. Cloth, \$1.

\section{The Cottage and Farm Bee-keeper;}

A Practical Work, by a Country Curate, 50 centa.

\section{Weeks (John. II.) on Bees.-A Hanual;}

Or, an Easy Methnd of Managing Bees in the most frofitable nanner to their owner; with infallib'e rules to prevent their destruction by the Moth. With an Appendix by Wooster A. Flanders. Price $5 u$ cts.

\section{The Rose;}

Being a Practical Treatise on the Propagation, Cult1sation, and Management of the Rose in all Seasons; with a List of Choice and Aproved Varicties, adafited to tho Climate of the United Strtes; to which is added Full Directions for the Treatment of the Dullia. Illustrated by engravings. Cloth, $50 \mathrm{cts}$.

\section{Buist's (Robert) American Flower-Garden Directory;}

Containing l'ractical Directions fur the Cuiture of Plants, in the Flower-Garden, HotHouse, Green-IIouse, Iooms, or Parlor Windows, fur every Month in the Year; with a description of the Plants most desirable in each, the Nature of the Soil and Situation best adapied to their Growth, the Proper Season for Transplanting, \&c.; with Instructions for erecting a Hot-House, Green-Honce, and Lyying ont a Flower-Garden; the whole adapted to either large or small Gardens; wlib Instructions for Preparing the 8uil, Propagating, Plautlng. Pruning, Trulning, and Fraiting the Grape Vine. Prlce $\$ 125$.

\section{Bnists' (Robert) Family Kitchen Gardener;}

Containing Plain and Accurate Deicriptions of all the different Snecies and Farietics of Cu'inary Vegetables, with their Botanical, Eng'ish, French, and German names, alphabetically arranged, and the best mode of culivating them in the garden or under glass; alie, Descipitions and Character of the most Select Fruits, their Mianageinent, Propagation, \&ec. By Robert Bnist, anthor of the "American Flower-Garden Dirsc. tory," \&c. Cloth, $75 \mathrm{cts}$; 1,2per $30 \mathrm{cts}$.

\section{The American Florist's Guiae;}

Cumprising the An ricin Rose Culturist and Erery Lady her own Flower Garduner. Usif eluth, i5 ets 



